UNIVERSIDADE DE SÃO PAULO

FACULDADE DE ECONOMIA, ADMINISTRAÇÃO E CONTABILIDADE DEPARTAMENTO DE CONTABILIDADE E ATUÁRIA

PROGRAMA DE PÓS-GRADUAÇÃO EM CONTROLADORIA E CONTABILIDADE

CÍNTIA DO NASCIMENTO SILVA

\title{
CONTE COMIGO!
}

Características da Consultoria Contábil aos Pequenos Negócios

SÃo PAULO

2015 
Prof. Dr. Marco Antonio Zago

Reitor da Universidade de São Paulo

Prof. Dr. Adalberto Américo Fischmamn

Diretor da Faculdade de Economia, Administração e Contabilidade

Prof. Dr. Gerlando Augusto Sampaio franco de Lima

Chefe do Departamento de Contabilidade e Atuária

Prof. Dr. Andson Braga de Aguiar

Coordenador do Programa de Pós-Graduação em Controladoria e Contabilidade 


\section{CÍNTIA DO NASCIMENTO SILVA}

\section{CONTE COMIGO!}

A Consultoria Contábil às Micro e Pequenas Empresas

Dissertação apresentada ao Departamento de Contabilidade e Atuária, da Faculdade de Economia, Administração e Contabilidade, da Universidade de São Paulo, como requisito parcial para a obtenção do título de Mestra em Ciências.

Orientadora: Prof.a Dr.a Silvia Pereira de Castro Casa Nova

Versão Corrigida

SÃO PAULO

2015 
FICHA CATALOGRÁFICA

Elaborada pela Seção de Processamento Técnico do SBD/FEA/USP

Silva, Cíntia do Nascimento.

Conte comigo! Características da consultoria contábil aos

pequenos negócios / Cíntia do Nascimento Silva. -- São Paulo, 2015. $178 \mathrm{p}$.

Dissertação (Mestrado) - Universidade de São Paulo, 2015.

Orientador: Silvia Pereira de Castro Casa Nova.

1. Consultoria de empresas. 2. Microempresas. 3. Contabilidade de microempresas. I. Universidade de São Paulo. Faculdade de Economia, Administração e Contabilidade. II. Título.

CDD -658.46

Autorizo a reprodução e divulgação total ou parcial deste trabalho, por qualquer meio convencional ou eletrônico, para fins de estudo e pesquisa, desde que citada a fonte. 
Nome: Cíntia do Nascimento Silva

Título: CONTE COMIGO! Características da Consultoria Contábil aos Pequenos Negócios

Dissertação apresentada ao Departamento de Contabilidade e Atuária, da Faculdade de Economia, Administração e Contabilidade, da Universidade de São Paulo, como requisito parcial para a obtenção do título de Mestra em Ciências.

Aprovado em:

Banca Examinadora

Prof. Dr.

Instituição: Assinatura:

Prof. Dr.

Instituição: Assinatura:

Prof. Dr.

Instituição: Assinatura: 
À minha mãe. 


\section{AGRADECIMENTOS}

Agradeço primeiramente aos meus ancestrais, às pessoas que vieram antes de mim preparando o caminho para que aqui eu chegasse e para que daqui eu continue seguindo. Agradeço especialmente à minha mãe, mulher de força incansável, aquela que me fez entender o sentido da palavra heroína. Sem a força dela a me inspirar, eu, pouco de mim seria. Agradeço imensamente a outra mulher que também foi minha inspiração, humana e profissional, a querida Silvia, para quem a palavra orientadora, apesar de tão grande, ficou pequena. Agradeço-Ihe por todo incentivo, apoio e iluminação. Agradeço a todas e todos Especialistas e Proprietários de Pequenos (Grandes) Negócios que compartilharam suas histórias comigo. Na verdade, este trabalho só existe graças a vocês e espero que o resultado dele contribua de alguma forma para que nós, contadoras e contadores, sejamos cada vez mais parceiras e parceiros de vocês e de seus sonhos. Agradeço a todas as professoras e professores que fizeram parte do meu Mestrado. Agradeço à Professora Márcia Espejo pelas sugestões de pesquisas e oportunidade de conhecer o competente e acolhedor PPGCont da UFPR. Agradeço aos Professores Adelino De Bortoli Neto e Almir Souza pelo apoio e sugestões. Agradeço às amigas e aos amigos do Mestrado, com quem compartilhei alegrias e angustias nessa caminhada. Agradeço ao meu irmão Fernando, que me deu grande ajuda. Agradeço a todas e todos que, direta ou indiretamente, fizeram parte dessa jornada. 
Acredite no seu negócio. Se você não acreditar, quem vai?

Luiza Trajano 


\section{RESUMO}

Silva, C. N. (2015). CONTE COMIGO! Características da Consultoria Contábil aos Pequenos

Negócios. Dissertação de Mestrado, Programa de Pós-graduação em Controladoria e Contabilidade, Universidade de São Paulo, São Paulo.

As Micro e Pequenas Empresas (MPEs) têm papel relevante na economia brasileira. Contribuíram com a formação de 27\% do Produto Interno Bruto em 2011 (SEBRAE, 2014) e geraram 52\% dos empregos formais no país em 2012 (SEBRAE, 2013). Apesar disso, 24,4\% desses empreendimentos desaparecem nos primeiros dois anos de vida (SEBRAE, 2013). Essas empresas são os principais clientes dos contadores e escritórios contábeis que prestam, geralmente, serviços de escrita contábil, escrita fiscal, departamento pessoal e de abertura, alterações e encerramento de empresas. A consultoria contábil, além de oferecer apoio aos Proprietários Administradores de Pequenos Negócios (PAPNs) para enfrentar os desafios comuns às MPEs, representa uma área a ser explorada pelos contadores. A partir desse contexto, este trabalho procurou caracterizar a consultoria contábil a ser oferecida pelos profissionais de contabilidade aos PAPNs. Para isso, 23 entrevistas semiestruturadas foram realizadas com 8 PAPNs e 15 Especialistas, além de um relato de memória, gerando mais de 15 horas de áudio e 146 páginas de transcrições. A estratégia de análise das entrevistas foi a Grounded Theory, utilizando-se a técnica de codificação proposta por Charmaz (2006) e com o auxílio do software QSR-Nvivo, versão 10. De acordo com os dados analisados na pesquisa e com a literatura consultada, a natureza do serviço da consultoria contábil pode ser divida em três categorias: ferramentas, treinamento e aconselhamento. As ferramentas aconselhadas pelo consultor incluem relatórios e técnicas e rotinas de controles essenciais para auxiliar a gestão e a tomada de decisão do PAPN. O treinamento é direcionado ao entendimento e ao 'como fazer' algo, enquanto os aconselhamentos têm como principal foco ajudar o PAPN a sair do operacional para pensar no negócio, sua estratégia e administração e a desenvolver sua visão empreendedora. Para isso, é imprescindível que o contador busque preparo em múltiplas áreas, especialmente em administração. A relação de confiança entre o contador e o PAPN é essencial na consultoria contábil, bem como a adoção, pelo contador, de linguagem simples e clara. A consultoria coletiva é sugerida como um possível mecanismo de viabilizar economicamente a prestação desse serviço. Não se propõe aqui a substituição dos serviços oferecidos hoje pelos escritórios contábeis às MPEs, os quais são vistos pelos PAPNs como a principal função do contador, mas sim o seu complemento com o intuito de ajudar esse empresariado a superar as dificuldades específicas das empresas de menor porte. Afinal, como afirmam Marriott e Marriott (2000), os serviços tradicionais podem representar uma janela de oportunidade para a consultoria contábil.

Palavras-chave: Consultoria Contábil, Micro e Pequenas Empresas, Contabilidade de Micro e Pequenas Empresas 


\begin{abstract}
Silva, C. N. (2015). STAND BY ME! Characteristics of Accountancy Consulting for Small Business. Master's Degree Dissertation, Graduate Degree Program in Controllership and Accounting, University of São Paulo, São Paulo.

The Micro and Small Enterprises (MSEs) have a relevant role in the Brazilian economy. They contributed to the formation of 27\% of GDP in 2011 (SEBRAE, 2014) and generated 52\% formal employment in the country in 2012 (SEBRAE, 2013). Nevertheless, 24.4\% of these enterprises disappear in the first two years of life (SEBRAE, 2013). Those companies are the main clients of accountants and accounting firms that provide generally statutory accounting services, tax records, personnel department and opening, changes and closing of a business. The accountancy consulting offers support to Small Business Owners Administrators (SBOAs) to face common challenges to MSEs, and it represents an area to be explored by accountants. From this context, this study aimed to characterize the accounting consultancy to be offered by accounting professionals to SBOAs. For this, 23 semi-structured interviews were conducted with 8 SBOAs and 15 Specialists, plus a memory reporting, generating more than 15 hours of audio and 146 pages of transcripts. The interviews analysis strategy was the Grounded Theory, using the coding technique proposed by Charmaz (2006) and with the aid of QSR-Nvivo software, version 10. According to the data analyzed in the study and the literature, the nature of the accounting consultancy service can be divided into three categories: tools (reporting and control techniques), training and advice. The tools recommended by the consultant include reports, routines and essential control techniques to assist management and decision making of SBOA. Training is directed at understanding and 'how to do' something, while advice is focused primarily on helping the SBOA exiting of enterprise operations to think about the business, its strategy and management and to develop their entrepreneurial vision. Therefore, it is essential to seek accountant preparation in multiple areas, especially in management. The trust relationship between accountant and the SBOA is essential in accounting consultancy, as well as the adoption by accountant of a simple and clear language. The collective consultancy is suggested as a possible mechanism of economically viable to provide that service. It is not proposed here to replace the services offered today by the accounting firms to MSEs, which are seen by SBOAs as the main function of accountant, but its complement in order to help these entrepreneurs to overcome the specific difficulties of small business. After all, as stated by Marriott and Marriott (2000), traditional services may represent a window of opportunity for the accounting consultancy.
\end{abstract}

Key-words: Accounting Consultancy, Micro and Small Enterprises, Micro and Small Business Accounting. 


\section{SUMÁRIO}

LISTA DE TABELAS

LISTA DE FIGURAS

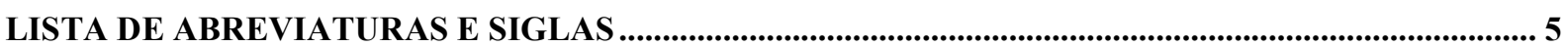

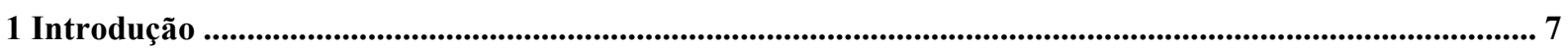

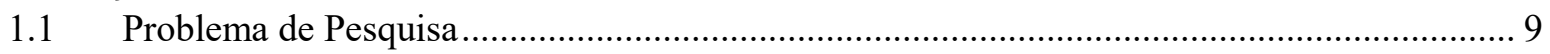

1.2 Objetivos Geral e Específicos ......................................................................... 10

1.2.1 Objetivo Geral .............................................................................................. 10

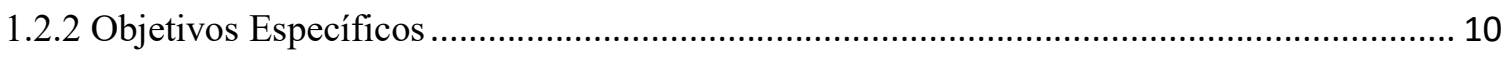

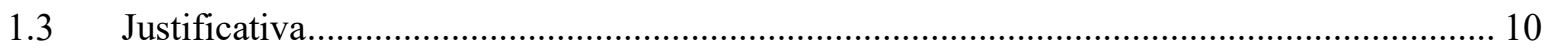

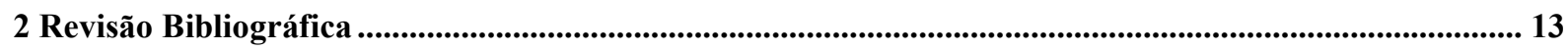

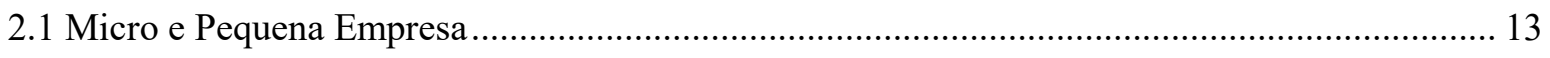

2.1.1 Definição de Micro e Pequena Empresas .............................................................. 13

2.1.2 Contexto das Micro e Pequenas Empresas ............................................................... 15

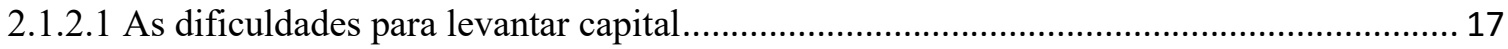

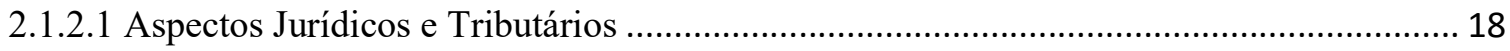

2.2 Os Proprietários-Administradores de Pequenos Negócios (PAPNs) ................................... 20

2.3 A Contabilidade e a Gestão das Micro e Pequenas Empresas.............................................. 21

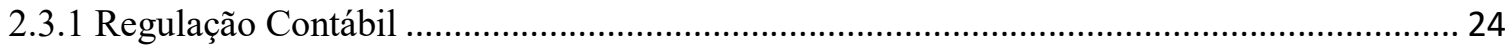

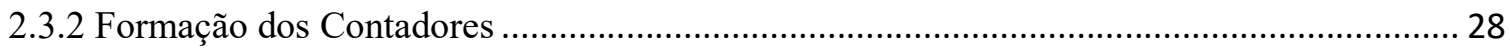

2.4 A Consultoria às Micro e Pequenas Empresas ................................................................ 30

2.4.1 A Consultoria Contábil às Micro e Pequenas Empresas ................................................. 36

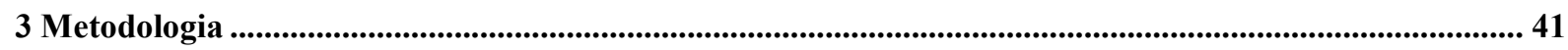

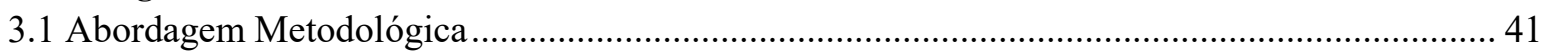

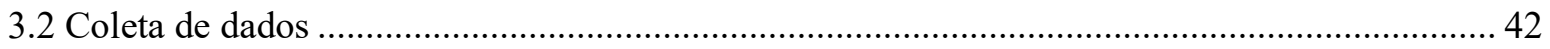

3.3 Apresentação dos Sujeitos da Pesquisa e do Roteiro de Entrevistas ..................................... 46

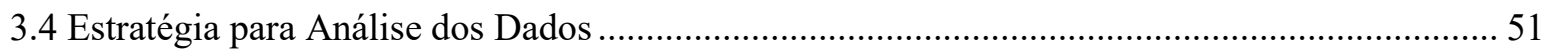

4 Análise e Discussão dos Dados .............................................................................................................................61

4.1 Aspectos associados aos Proprietários Administrados de Pequenos Negócios (PAPNs) ........... 61

4.2 Aspectos associados ao Contexto das MPEs ................................................................. 72

4.3 Aspectos associados ao Escritório Contábil e aos Profissionais de Contabilidade ...................81

4.3.1 Honorários Contábeis e Percepção de Qualidade dos Serviços...................................... 88

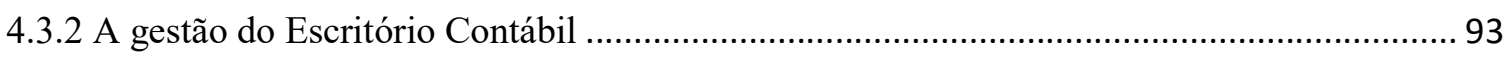

4.3.3 A Formação do Contador e seus reflexos na rotina de atendimento de MPEs.................... 96

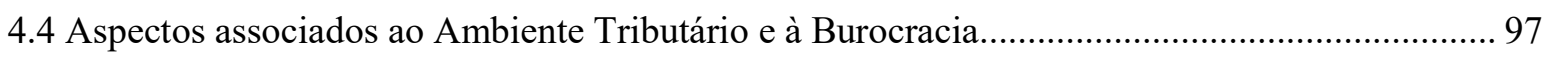

4.5 Aspectos associados à Comunicação......................................................................... 101

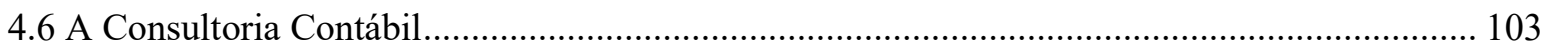




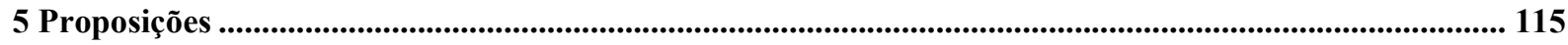

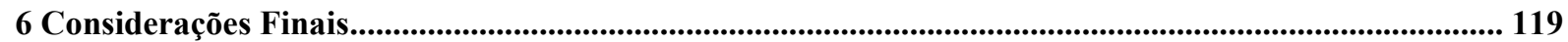

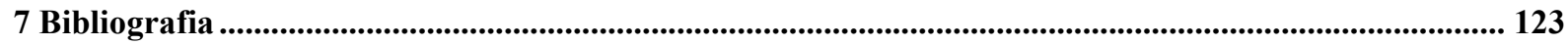

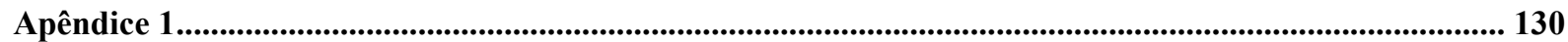

Apêndice 2 


\section{LISTA DE TABELAS}

Tabela 1: Estudos sobre contabilidade e pequenas empresas do Departamento de Contabilidade da FEA-USP.

Tabela 2: Classificação dos estabelecimentos segundo o porte - SEBRAE ........................................... 13

Tabela 3: Classificação dos estabelecimentos segundo o porte - BNDES ……………......................... 14

Tabela 4: Classificação dos estabelecimentos segundo o porte - MERCOSUL ……............................ 14

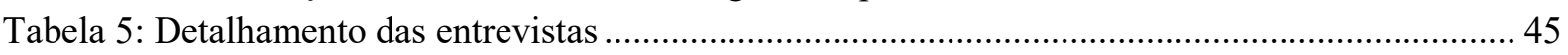

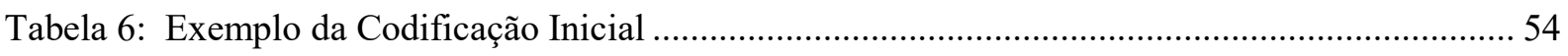

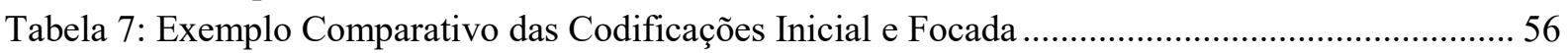

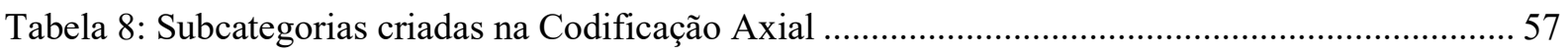

Tabela 9: Distribuição da quantidade de nós por Categorias e Entrevistados ........................................ 59

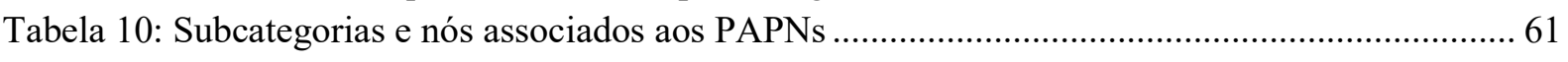

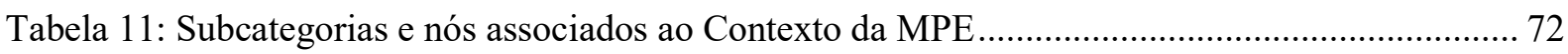

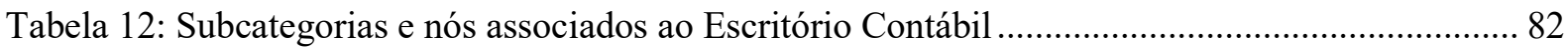

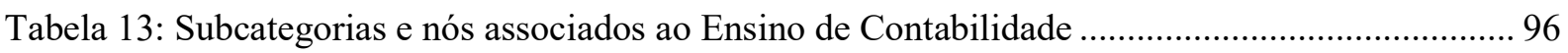

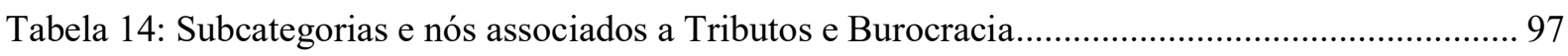

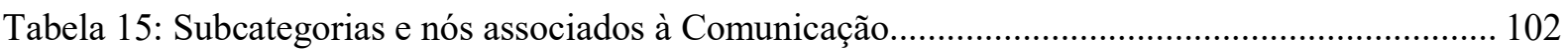

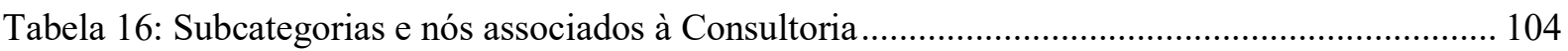




\section{LISTA DE FIGURAS}

Figura 1: Representação do Processo de Codificação dos Dados ......................................................... 54

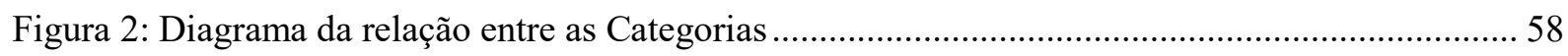




\section{LISTA DE ABREVIATURAS E SIGLAS}

EPP: Empresa de Pequeno Porte

FAPESP: Fundação de Amparo à Pesquisa do Estado de São Paulo

FEA: Faculdade de Economia, Administração e Contabilidade

FGTS: Fundo de Garantia por Tempo de Serviço

FGV: Fundação Getúlio Vargas

GFIP: Guia de Recolhimento do FGTS e Informações a Previdência Social

IASB: International Accounting Standards Board

IBGE: Instituto Brasileiro de Geografia e Estatística

ICMS: Imposto sobre Circulação de Mercadorias e Prestação de Serviços

IFRS: International Financial Reporting Standards

INSS: Instituto Nacional do Seguro Social

ISS: Imposto sobre Serviços

ITG: Interpretação Técnica Geral

ME: Microempresa

MEI: Microempreendedor Individual

MERCOSUL: Mercado Comum do Sul

MPEs: Micro e Pequenas Empresas

NBC TG: Normas Brasileiras de Contabilidade Técnica Geral

PAPNs: Proprietários-Administradores de Pequenos Negócios

PE: Pequena Empresa

PIB: Produto Interno Bruto

PMELab: Laboratório de Pequenas Empresas

PMEs: Pequenas e Médias Empresas

PPGCC: Programa de Pós-Graduação em Controladoria e Contabilidade

RFB: Receita Federal do Brasil

SEBRAE: Serviço de Apoio às Micro e Pequenas Empresas

SEFIP: Sistema Empresa de Recolhimento do FGTS e Informações à Previdência Social

SICALC: Programa para Cálculo e Emissão de DARF

SIMPLES: Sistema Integrado de Pagamento de Impostos e Contribuições das

Microempresas e Empresas de Pequeno Porte

SME: Small Medium Business

SPED: Sistema Público de Escrituração Digital

SUSEP: Superintendência de Seguros Privados

USP: Universidade de São Paulo 


\section{Introdução}

As Micro e Pequenas Empresas (MPEs) desempenham importante papel na economia brasileira. Em 2012, somavam 6,3 milhões de estabelecimentos, representando 99\% das empresas do país, e respondiam por 16,2 milhões de empregos formais privados não agrícolas, ou seja, 52\% dos empregos formais (SEBRAE, 2013). Esses empreendimentos, à medida que geram riquezas, democratizam o acesso ao trabalho e aos meios de produção e o "sucesso micro empresarial importa na redução dos problemas sociais, na diminuição das taxas de desemprego, no desenvolvimento de pequenas e médias comunidades ..., incapazes de atrair empresas de grande porte (Ferronato, 2011, p. 4).

Os pequenos e micro negócios contribuem de maneira importante para o crescimento do Produto Interno Bruto (PIB) brasileiro. Estudo recente realizado pelo Serviço de Apoio às Micro e Pequenas Empresas (SEBRAE) em parceria com a Fundação Getulio Vargas (FGV) indicou a contribuição dos pequenos negócios na formação do PIB de 27\% em 2011 (23,2\% em 2001 e $21 \%$ em 1985). Essa proporção é ainda maior no setor de comércio, no qual a participação das MPEs é de 53,4\% do PIB (sendo 22,5\% na indústria e 24,5 no setor de serviços) (SEBRAE, 2014).

Assim como no Brasil, esses negócios são majoritários em muitas economias no mundo. Na União Europeia, esses empreendimentos representam 98\% do número total de empresas e juntamente com as empresas de médio porte são responsáveis por $60 \%$ da mão-deobra empregada (Vetter \& Köhler, 2014). Na América Latina e Caribe, as MPEs representam 95\% dos negócios formais, geram 35\% dos empregos regulares e respondem por 33\% do PIB da região [participação na formação do PIB é ainda maior em países como Argentina (60\%), El Salvador (44\%) e Peru (42\%)] (SEBRAE, 2010). Na Austrália, 96\% dos negócios em operação são de pequenas empresas (Stone, 2011).

Apesar do peso das MPEs nas economias, a sobrevivência desses empreendimentos ainda é alvo de atenção. Na zona do euro, por exemplo, as taxas de sobrevivência nos primeiros dois anos são: de 70\% na Irlanda e na Alemanha, 66\% na Itália, 62\% na França e no Reino Unido e 56\% em Portugal (Bridge; O’neil; Cromie, como citado em Raifur, 2013). No Brasil, 75,6\% desses negócios sobrevivem aos primeiros anos de vida (SEBRAE, 2013).

Nos últimos anos, as taxas de sobrevivência das MPEs brasileiras apresentaram melhora significativa, por exemplo, o percentual de empresas que sobrevivem, pelo menos 
dois anos, passou de 50,6\% em 2002 para 78\% em 2005 (SEBRAE, 2007). As taxas brasileiras, ressalvadas as diferenças de metodologia de apuração, se aproximam às taxas internacionais de economias desenvolvidas (As taxas para negócios com mais de cinco anos eram 73,6\% em 2005; 75,1\% em 2006 e 75,6\% em 2007) (SEBRAE, 2013). Apesar da melhora, parte relevante desses negócios continuam desaparecendo nos primeiros anos de existência, fazendo com que a dedicação ao tema permaneça em evidência.

Na visão dos micro e pequenos empresários, os fatores que mais contribuem para esse cenário são a falta de capital de giro, a carga tributária elevada, a falta de crédito bancário e os maus pagadores (SEBRAE, 2007). Além desses fatores apontados pelos empresários, a literatura indica a deficiência gerencial-administrativa desses gestores como fator relevante na continuidade e sucesso do empreendimento (Carneiro \& Dall'Agnol, 2005/2004; Longenecker, Moore \& Petty, 1998; Casa Nova, 1996).

Os problemas e desafios das MPEs são diferentes daqueles presentes nas empresas de grande e médio portes. De acordo com Bortoli Neto (1980), em trabalho seminal sobre as Pequenas e Médias Empresas (PMEs) brasileiras, essas empresas têm "uma estrutura diferenciada e, por isso, a forma de resolver seus problemas é específica” (p.2). O processo de gestão desses empreendimentos pode ser apoiado e facilitado pelas informações geradas pela Contabilidade. Porém, embora a maioria desses empresários conte com serviços de um contador ou escritório contábil, esses serviços confundem-se com o atendimento de obrigações burocráticas e fiscais (Moreira, Encarnação, Bispo Neto, Angotti, \& Colauto, 2013; Hochsprung, Borges, Freitas, Espíndola, \& Ventura, 2011; Lima Junior \& Carvalho, 2010; Miranda L. C., Libonati, Freire, \& Saturnino, 2008).

Comumente, as informações fornecidas pelos escritórios distanciam-se daquelas demandadas pelos usuários. Outras vezes, o empresário não conhece que tipo de informação oriunda da contabilidade pode lhe ser útil ou não sabe interpretá-la (Silva \& Marion, 2013; Villa, 2012; Ferronato, 2011). Em meio a problemas comunicacionais, dentre outros, na relação proprietário-contador (Silva \& Marion, 2013; Villa, 2012), o contabilista é visto por grande parte desse grupo de empresários como "mal necessário" (Casa Nova, 1996).

Diferentemente do caso brasileiro, em outros países o contabilista é percebido como um consultor pelos micro e pequenos empreendedores. Segundo Carter, Mason e Tagg (2006), no Reino Unido, os contadores são a fonte de consultoria de negócios mais procurada pelos "small business owners", representando $74 \%$ de toda a consultoria prestada a esse 
público, com elevado índice de satisfação dos clientes quanto ao apoio oferecido pela categoria profissional.

Dado que há cenários em que o contador é visto como um consultor de negócios pelos PAPNs, o presente trabalho procura levantar as características concernentes à consultoria a ser oferecida às MPEs pelo profissional de contabilidade no Brasil, para além daqueles serviços comumente oferecidos aos PAPNs, tais como: serviços de escrituração contábil e físcal, de folha de pagamento e de abertura, alteração e encerramento de empresas, a fim de auxiliar esses profissionais no oferecimento de consultoria a esse público.

\subsection{Problema de Pesquisa}

Embora por força de lei todas as micro e pequenas empresas tenham que manter um sistema de contabilidade feito por um contabilista habilitado (BRASIL, Lei no 10406 - Código Civil Brasileiro, 2002), o que se vê na prática é a atuação do contador mais voltada para o atendimento de obrigações fiscais e trabalhistas, explicitadas na confecção de Documento de Arrecadação de Receitas Federais (DARF) e de Folha de Pagamento de Salários (Moreira, Encarnação, Bispo Neto, Angotti, \& Colauto, 2013; Hochsprung, Borges, Freitas, Espíndola, \& Ventura, 2011; Lima Junior \& Carvalho, 2010; Ueno \& Casa Nova, 2006) do que na geração de informações contábeis tal como prescrito nas Resoluções do Conselho Federal de Contabilidade números 1255/09 e 1418/12.

As MPEs são os principais clientes dos escritórios contábeis. Carneiro e Dall'Agnol (2005/2004) mencionam a existência de mais de 350 mil profissionais atendendo esse segmento, com uma média de 50 pequenas empresas atendidas por organização contábil. Os autores também afirmam que o contabilista é um potencial consultor em gestão desde que devidamente preparado. Segundo eles, esse profissional é um "agente capaz de contribuir de forma mais eficaz para a sobrevivência das empresas" (p. 17). Padula (1996), no final da década de 1990, já sinalizava a importância dos profissionais de contabilidade de diversificarem suas atividades incluindo a consultoria de gestão às Pequenas e Médias Empresas (PMEs) em seus portfólios de atividades, quando previa a possível perda do protecionismo legal ao monopólio da atividade, bem como o efeito das tecnologias da informação na dinamização do levantamento de informação contábil. Apesar de não ter ocorrido a perda do monopólio de atuação, uma vez que a lei continua limitando o exercício da profissão aos profissionais habilitados, movimentos de simplificação de tributos e 
obrigações acessórias com a Lei de Simples, o Sistema Público de Escrituração Digital (SPED) e o e-Social podem reduzir em longo prazo a procura por uma contabilidade com foco nessas atividades.

Muitos são os trabalhos internacionais que abordam aspectos envolvidos na consultoria oferecida às MPEs e PMEs (Carey, 2015; Jarvis \& Rigby, 2012; Blackburn, Carey, \& Tanewski, 2010; Dyer \& Ross, 2007; Johnson, Webber, \& Thomas, 2007; Gooderham, Tobiassen, Doving, \& Nordhaug, 2004; Bennett \& Robson, 2004; Jay \& Schaper, 2003; Bennett, Obson, \& Bratton, 2001; Robson \& Bennett, 2000; Bennett \& Robson, 1999), porém, esses trabalhos não caracterizam essa consultoria em si.

A partir desse cenário, o presente trabalho pretende responder a seguinte questão de pesquisa: Quais as características da consultoria contábil a ser oferecida pelos profissionais de contabilidade aos Proprietários Administradores de Pequenos Negócios (PAPNs) com o propósito de ajudá-los na lida com as dificuldades específicas das Micro e Pequenas Empresas (MPEs)?

\subsection{Objetivos Geral e Específicos}

\subsubsection{Objetivo Geral}

Caracterizar a consultoria contábil a ser oferecida pelos profissionais de contabilidade aos Proprietários Administradores de Pequenos Negócios (PAPNs) com o propósito de ajudálos na lida com as dificuldades específicas das Micro e Pequenas Empresas.

\subsubsection{Objetivos Específicos}

a) Identificar quais são as dificuldades comuns enfrentadas pelos PAPNs na gestão das MPEs.

b) Verificar de que tipo de apoio os PAPNs precisam para enfrentar as dificuldades detectadas no item a.

c) Traçar as características da consultoria a ser oferecida pelos profissionais de contabilidade aos PAPNs.

\subsection{Justificativa}

Os estudos e pesquisas sobre pequenas empresas são de interesse de cinco principais grupos, segundo Curran \& Blackburn (2001): acadêmicos e pesquisadores; formuladores de políticas públicas; organismos de apoio, investidores privados e proprietários de pequenos negócios. Porém, embora tenha aumentado o volume de pesquisas na Inglaterra, por exemplo, a importância econômica dos pequenos negócios é frequentemente subestimada. Para os 
autores, "uma razão para isso é a tendência de ver as pequenas empresas como menos centrais para as atividades econômicas do que as grandes empresas, particularmente, as multinacionais, cujas operações são foco em programas de negócios em jornais e televisão." (Curran \& Blackburn, 2001, p. 1).

No Brasil, os estudos acadêmicos voltados para esse público ainda são tímidos e escassos, com parco número de publicações e estudos nacionais sobre o assunto, inclusive na área contábil. Em 1980, Bortoli Neto ressaltou a situação ao afirmar que "todo e qualquer trabalho embasado numa pesquisa, que tenha como objetivo conhecer melhor a realidade das PMEs, justifica-se por si só, pois a carência de informações nesta área é inversamente proporcional a sua importância na economia nacional e regional" (p.4). Desde então, muitas pesquisas foram feitas, porém, o número continua desproporcional à importância desses negócios na sociedade brasileira. Um exemplo disso é o número de defesas feitas no Programa de Pós-Graduação em Controladoria e Contabilidade (PPGCC) da Faculdade de Economia, Administração e Contabilidade (FEA) da Universidade de São Paulo (USP), programa pioneiro na área, que foi por muito tempo o único a formar doutores em Contabilidade em todo o país, com apenas 15 trabalhos defendidos sobre PME, são eles: 
Tabela 1: Estudos sobre contabilidade e pequenas empresas do Departamento de Contabilidade da FEA-USP

\begin{tabular}{|c|c|c|}
\hline Título & Autor & Ano \\
\hline $\begin{array}{l}\text { Conceitos de contabilidade gerencial aplicados às pequenas e médias } \\
\text { empresas. }\end{array}$ & Nakagawa, M. & 1976 \\
\hline $\begin{array}{l}\text { Indicadores contábeis e financeiros para previsão de insolvência: a } \\
\text { experiência da pequena e média empresa brasileira. (Tese Livre- } \\
\text { Docência) }\end{array}$ & Kanitz, S.C. & 1976 \\
\hline As empresas de pequeno porte e a contabilidade & Casa Nova, S.P.C. & 1996 \\
\hline $\begin{array}{l}\text { Modelo conceitual de mensuração de resultado para micro e } \\
\text { pequenas indústrias: um enfoque em Gestão Econômica - GECON }\end{array}$ & Alves, N. J. F. & 1997 \\
\hline $\begin{array}{l}\text { Informações contábeis- financeiras para empreendedores de } \\
\text { empresas de pequeno porte }\end{array}$ & Oliveira, A. M. de & 2001 \\
\hline $\begin{array}{l}\text { Uma contribuição ao estudo da decisão de preços nas micro, } \\
\text { pequenas e médias empresas }\end{array}$ & Silva, R. M. de S. & 2001 \\
\hline $\begin{array}{l}\text { Informações contábeis e o processo decisório em pequenas empresas: } \\
\text { estudos exploradores da cidade de Goiânia }\end{array}$ & Ferreira Neto, B. J. & 2002 \\
\hline $\begin{array}{l}\text { Avaliação do desempenho das empresas financiadas pelo PROGER } \\
\text { na região de Santa Maria/RS }\end{array}$ & Gräbner, S. & 2003 \\
\hline $\begin{array}{l}\text { Informação gerencial: seu fornecimento pelas organizações contábeis } \\
\text { do município de Florianópolis aos gestores das empresas de pequeno } \\
\text { porte do setor hoteleiro }\end{array}$ & Maciel, J. M. & 2003 \\
\hline $\begin{array}{l}\text { Escala hierárquica do risco setorial (EHRS) das pequenas empresas: } \\
\text { um estudo de caso }\end{array}$ & Nakao, A. N. & 2003 \\
\hline $\begin{array}{l}\text { Implementação de ERP em pequenas e médias empresas: estudo de } \\
\text { caso em empresas do setor da construção civil }\end{array}$ & Valente, N. T. Z. & 2004 \\
\hline $\begin{array}{l}\text { Métodos de custeio e custeio alvo: uma contribuição ao estudo de } \\
\text { custos em organizações hospitalares }\end{array}$ & Lima Júnior, E. de & 2006 \\
\hline $\begin{array}{l}\text { Fatores limitantes em implementações de sistemas de custos em } \\
\text { empresas de porte médio: um estudo de caso }\end{array}$ & Suzuki, R. & 2008 \\
\hline $\begin{array}{l}\text { Ciclo de vida organizacional e artefatos de contabilidade gerencial: } \\
\text { uma investigação nas } 250 \text { pequenas e médias empresas que mais } \\
\text { cresceram no Brasil entre } 2008 \text { e } 2010\end{array}$ & Valeriano, C. E. B. & 2012 \\
\hline $\begin{array}{l}\text { Adoção do Padrão Contábil Internacional nas Pequenas e Médias } \\
\text { Empresas e seus Efeitos na Concessão de Crédito }\end{array}$ & Riva, E. D. & 2013 \\
\hline
\end{tabular}

Fonte: Adaptado de Amaral e Casa Nova (2010)

Os estudos voltados a esse público interessam aos formuladores de políticas públicas à medida que auxiliam na formulação de ações para o desenvolvimento e sustentabilidade desses negócios como impacto socioeconômico para todo o país. Além disso, existem no Brasil, de acordo com o CFC (2015), 520.900 Contabilistas ativos, sendo 323.858 Contadores e 197.042 Técnicos em Contabilidade, e 48.313 organizações contábeis. Como esses profissionais e entidades têm como principais clientes as MPEs, o entendimento sobre a consultoria adequada aos PAPNs, bem como, sobre a atuação do contador nessa atividade, poderá ajudar a categoria, as entidades de classe e os educadores da área a se prepararem para explorar as oportunidades dessa atividade e aumentar o prestígio e a eficácia social da profissão. 


\section{Revisão Bibliográfica}

\subsection{Micro e Pequena Empresa}

\subsubsection{Definição de Micro e Pequena Empresas}

O desafio primário no estudo da pequena empresa é a sua definição, pois são muitas as possibilidades de classificação do porte empresarial, podendo envolver tanto características quantitativas, quanto qualitativas.

No Brasil, são usados critérios diferentes dependendo do órgão classificador e de seus objetivos. Segundo o Instituto Brasileiro de Geografia e Estatística (IBGE), o número de funcionários empregados é o fator determinante para definição, sendo microempresa aquela que emprega até 9 funcionários; pequena empresa, de 10 a 49; média, 50 a 249 pessoas e grande empresa aquela que emprega 250 funcionários ou mais (IBGE, 2014).

Similarmente ao IBGE, o Serviço Brasileiro de Apoio às Micro e Pequenas Empresas (SEBRAE) utiliza o critério de pessoas ocupadas para classificar o porte das empresas, porém, o faz separando entre Indústria e Comércio e Serviços, tal como apresentado na Tabela 2 apresentada a seguir:

Tabela 2: Classificação dos estabelecimentos segundo o porte - SEBRAE

\begin{tabular}{|l|c|c|}
\hline \multirow{2}{*}{\multicolumn{1}{|c}{ Porte }} & \multicolumn{2}{c|}{ Setores } \\
\cline { 2 - 3 } & Indústria & Comércio e Serviços \\
\hline Microempresa & até 19 pessoas ocupadas & até 9 pessoas ocupadas \\
\hline Pequena empresa & de 20 a 99 pessoas ocupadas & de 10 a 49 pessoas ocupadas \\
\hline Média empresa & de 100 a 499 pessoas ocupadas & de 50 a 99 pessoas ocupadas \\
\hline Grande empresa & 500 pessoas ocupadas ou mais & 100 pessoas ocupadas ou mais \\
\hline
\end{tabular}

Fonte: Anuário do Trabalho 2013, SEBRAE, 2014.

A Receita Federal do Brasil (RFB), para fim de tributação simplificada, e o Banco Nacional do Desenvolvimento Econômico e Social (BNDES), para fim de concessão de crédito, utilizam critérios relacionados à receita para classificação do porte empresarial. A primeira, de acordo com a Lei Complementar $n^{\circ} 123$ de 14 de dezembro de 2006, classifica como microempresa aquela com receita no ano-calendário anterior de até $\mathrm{R} \$ 240.000,00$ e como empresa de pequeno porte aquela com receita bruta anual entre $\mathrm{R} \$ 240.000,01$ e R \$2.400.000,00 (BRASIL, Lei Complementar n.123, de 14 de dezembro de 2006, Art.3º, 2006). O segundo, BNDES, classifica conforme demonstrado na Tabela 3: 
Tabela 3: Classificação dos estabelecimentos segundo o porte - BNDES

\begin{tabular}{|l|c|}
\hline \multicolumn{1}{|c|}{ Porte } & $\begin{array}{c}\text { Receita Operacional } \\
\text { Bruta Anual }\end{array}$ \\
\hline Microempresa & inferior ou igual a $\mathrm{R} \$ 2.400 .000,00$ \\
\hline Pequena empresa & superior a $\mathrm{R} \$ 2.400 .000,00$ e inferior ou igual a $\mathrm{R} \$ 16.000 .000,00$ \\
\hline Média empresa & superior a $\mathrm{R} \$ 16.000 .000,00$ e inferior ou igual a $\mathrm{R} \$ 90.000 .000,00$ \\
\hline Média-grande empresa & superior a $\mathrm{R} \$ 90.000 .000,00$ e inferior ou igual a $\mathrm{R} \$ 300.000 .000,00$ \\
\hline Grande empresa & superior a $\mathrm{R} \$ 300.000 .000,00$ \\
\hline
\end{tabular}

Fonte: Circular $n^{\circ} 34$

Ambos consideram receita total como o produto da venda de bens e serviços nas operações de conta própria, o preço dos serviços prestados e o resultado nas operações em conta alheia, não incluídas as vendas canceladas e os descontos incondicionais concedidos (BRASIL, Lei Complementar n.123, 2006; BNDES, 2011)

Outros organismos utilizam critérios considerando número de empregados, tamanho do ativo e receita bruta total anual simultaneamente, como é o caso da União Europeia. O The European Commission define microempresa como aquela com até 9 empregados e faturamento ou ativo total anual de até dois milhões de euros, enquanto a pequena empresa tem entre 10 e 49 empregados e menos de dez milhões de euros em receita ou ativo total; e a empresa de médio porte com 50 a 249 empregados e faturamento ou ativo total de até quarenta e três milhões de euros (Vetter \& Köhler, 2014).

O Mercado Comum do Sul (MERCOSUL), a fim de buscar uma definição comum entre os Estados Partes, estabeleceu critérios de classificação do porte das empresas que incorporam aspectos qualitativos e quantitativos ratificadas pela Resolução $n^{0} 59$ de 1998, segundo a qual as empresas de micro, pequeno e médio portes "não deverão estar controladas por outra empresa ou pertencer a um grupo econômico que em seu conjunto supere os valores estabelecidos" (MERCOSUL, 1998). Os valores citados são apresentados na Tabela 4 a seguir:

Tabela 4: Classificação dos estabelecimentos segundo o porte - MERCOSUL

\begin{tabular}{|l|c|c|c|c|}
\hline \multirow{2}{*}{\multicolumn{1}{|c|}{ Porte }} & \multicolumn{2}{|c|}{ Indústria } & \multicolumn{2}{c|}{ Comércio e Serviços } \\
\cline { 2 - 5 } & Pessoal ocupado & Vendas anuais USS & Pessoal ocupado & Vendas anuais USS \\
\hline Microempresa & até 10 pessoas & até 400.000 & até 5 pessoas & até 200.000 \\
\hline Pequena empresa & de 11 até 40 pessoas & de $400.000,01$ até 3.500 .000 & de 6 até 30 pessoas & de 200.000,01 até 1.500 .000 \\
\hline Média empresa & de 41 até 200 pessoas & de $3.500 .000,01$ até 20.000 .000 & de 31 até 80 pessoas & de $1.500 .000,01$ até 7.000 .000 \\
\hline
\end{tabular}
Fonte: Resolução $n^{\circ}$ 59/98 MERCOSUL

Além dessas classificações, o Pronunciamento Técnico PME, correlato ao IFRS for $S M E$, define pequena e média empresa como sendo aquelas sem obrigação pública de 
prestação de contas e que elaboram demonstrações contábeis para fins gerais e para usuários externos (CPC, 2009); e o International Accounting Standards Board (IASB), o qual classifica microempresa como aquela que normalmente tem operações simples com as seguintes características típicas: poucos funcionários e o proprietário atuando como administrador, níveis baixos ou moderados de receitas e ativos brutos, além de não ter investimentos em coligadas e controladas e emissão de instrumentos financeiros complexos (IFRS Foundation, 2013).

Para Bortoli Neto (1980), a maneira como está organizada a direção dos pequenos negócios, bem como sua função e relação com a propriedade são definidores do porte. Para o autor, "na pequena empresa é reduzido o número de pessoas que ocupam postos diretivos, sendo muito comum essa tarefa ser desempenhada por uma única pessoa” (p.13). Além disso, Bortoli Neto aponta:

"a centralização dos assuntos no dirigente principal, tornando muito comum a figura do 'oneman' entre os empresários das PMEs .... O relacionamento direto e pessoal entre dirigentes e funcionários, dirigentes e clientes, dirigentes e fornecedores é outro ponto que distingue as PMEs das grandes empresas, assim como a forte relação entre direção e propriedade" (p.1314).

Como se pode perceber, as definições são muitas e variam entre aspectos qualitativos, quantitativos ou um misto dos dois. Porém, qualquer que seja a técnica empregada, tem-se sempre um critério arbitrário, dada a diversidade das empresas. Para fins deste trabalho, será empregada a definição de MPE utilizada pelo SEBRAE por ser uma das mais populares entre os contadores e os PAPNs, em função da forte campanha de divulgação da entidade.

Uma vez estabelecido um critério para a definição de MPE, para entender o contexto desses negócios é fundamental conhecer seus proprietários-administradores, seus perfis, seus principais objetivos, suas preferências comunicacionais e o impacto desses aspectos na gestão. Dessa forma, esses aspectos são discutidos a seguir.

\subsubsection{Contexto das Micro e Pequenas Empresas}

Raifur (2013), em sua tese de doutorado, estudou os fatores determinantes para o desempenho das PMEs e constatou que o planejamento antes da abertura da empresa, a experiência ocupacional, a experiência no ramo, a disponibilidade de capital e os empréstimos para constituição do negócio são indicadores influentes na sobrevivência dessas empresas e estão associados à fase de abertura do empreendimento. $\mathrm{O}$ autor conclui que as ações de apoio para garantir a sobrevivência das PMEs devem priorizar o período pré-instalação do negócio: 
Como há um número grande de indicadores influentes da sobrevivência de PMEs que estão associados com a fase anterior à abertura da empresa, em muitas situações, as ações e as alternativas tradicionalmente oferecidas após abertura podem apresentarem- se tardias a ponto de não contribuírem para a sobrevivência do empreendimento. Reflexões são requeridas no sentido de se desenvolverem políticas de conscientização que levem os potenciais empreendedores a capacitarem-se antes de abrir a empresa (Raifur, 2013, p. 171) [ênfase adicionada]

Essas empresas atuam em cenários, muitas vezes, pouco estimulantes e facilitadores. O Banco Mundial publica anualmente o relatório chamado 'Doing Business', no qual compara o ambiente regulatório para as pequenas e médias empresas de 189 economias. $\mathrm{Na}$ edição de 2014, o Brasil ocupa a posição de número 116 no item facilidade de realização de negócios, à frente da Argentina (126), mas atrás de seu outro vizinho, o Uruguai (88). Quando comparado aos BRICs, o país tem melhor cenário que a Índia (137ª posição), mas perde para os demais países: África do Sul $\left(41^{\mathrm{a}}\right)$, Rússia $\left(92^{\mathrm{a}}\right)$ e China $\left(96^{\mathrm{a}}\right)$. As primeiras posições do ranking são ocupadas por Cingapura em primeiro lugar, seguida por Hong Kong (China), Nova Zelândia e Estados Unidos em quarto lugar (The World Bank, 2014). Pode-se associar a posição pouco favorável do Brasil no referido ranking ao que a Deloitte chamou de "custo Brasil” na sétima edição do relatório 'As PMEs que Mais Crescem no Brasil', de 2012. Com uma amostra de 336 participantes, a pesquisa constatou que os desafios do ambiente de negócios mais impactantes no aumento de custos e que demandam mais esforços por parte das organizações são: o sistema legal e tributário (44\%); a legislação trabalhista (30\%); a captação de recursos $(7 \%)$; as condições de inovação $(7 \%)$; a cadeia de suprimentos $(6 \%)$; o ambiente econômico e demográfico (5\%); e, por fim, o comércio exterior (1\%) (Deloitte, 2012).

Em muitas das situações explanadas acima a contabilidade está envolvida. A capacitação dos potenciais empreendedores antes da abertura das empresas sugerida por Raifur (2013) como fator importante para aumentar as chances de sobrevivência do futuro empreendimento pode se dar pela busca de profissionais especializados, dentre os quais, o contador, quem pode atuar no planejamento tributário, nos estudos de custos, no levantamento das necessidades de capital e estudo das opções menos custosas etc. Essas atividades estão diretamente associadas à elaboração de orçamentos, de planos de negócios e de fluxos de caixa prospectivos, mas também estão presentes no dia a dia das MPEs nas situações apontadas pela Deloitte (2012), em especial no âmbito legal, trabalhista e de captação de recursos, as quais serão discutidas a seguir. 


\subsubsection{As dificuldades para levantar capital}

Tradicionalmente, as MPEs se financiam majoritariamente com capital próprio (Daskalakis, Jarvis e Schizas, 2013; Riva, 2013) e a falta de recursos financeiros, tanto no início da vida empresarial, quanto em seu decorrer, associados a problemas de registros e controles financeiros, levam as PMEs a buscarem fontes de capital inadequadas e excessivamente caras (Raifur, 2013). Dentre os recursos financeiros ausentes, a falta de capital de giro tem sido apontada como um problema comum nas MPEs, tanto na visão dos PAPNs (SEBRAE, 2007), quanto na literatura (Deloitte, 2012; Batista, Freitas, Soares e Rêgo, 2012; Trindade, Nunes, Linhares e Teixeira, 2010; Kassai e Casa Nova, 2006).

Em estudo para entender a forma de financiamento desse capital pelas PMEs de João Pessoa/PB, Machado, Machado e Callado (2006) observaram que as empresas não alcançaram equilíbrio financeiro e constataram que a maior parte das empresas analisadas não foi capaz de se autofinanciar, utilizando recursos de terceiros de curto prazo, geralmente de maior custo e de menor prazo para esse fim.

Segundo pesquisa feita por Daskalakis et al. (2013), as MPEs gregas usariam dívidas de longo prazo com custo menor, não fosse as limitações de acesso a esse tipo de crédito. Embora a pesquisa seja no cenário grego, os problemas enfrentados pelas MPEs daquele país apresentados pelos autores são muito similares àqueles vivenciados pelas MPEs brasileiras.

Riva (2013) identificou que o processo de concessão de crédito para as empresas de menor porte é bastante rigoroso em função do risco de fraude, o qual é bastante alto na visão dos agentes dos bancos entrevistados pelo pesquisador.

O conflito entre as solicitações das instituições financeiras e a realidade das pequenas empresas também apareceu no relatório da Deloitte sobre as 250 PMEs que mais cresceram em 2012. Segundo 56\% dos participantes da pesquisa, as garantias e exigências requeridas pelas instituições financeiras para a concessão de crédito eram barreiras associadas à captação de recursos, uma vez que, de um lado, as instituições financeiras cobram apresentação de relatórios, como o plano de negócios e os demonstrativos de gestão e, de outro lado, algumas PMEs têm dificuldades para organizar toda essa documentação e se enquadrar em todos os quesitos, dessa maneira, naquele ano a grande dificuldade deixou de ser o padrão elevado de taxas de juros (Deloitte, 2012, p. 11). 
Dentre as dificuldades apresentadas no âmbito da captação de recursos financeiros, também está a possibilidade de contribuição do contador em ajudar o PAPNs a superá-las por meio da elaboração de estudos comparativos das diversas opções de captação, permitindo a escolha daquela mais adequada as necessidades do negócio, da ajuda na elaboração de planos de negócios, de fluxos de caixa prospectivos que permitam simulação de cenários (Casa Nova, 1996) e da manutenção de um sistema de contabilidade confiável que reduza as assimetrias informacionais entre MPE e instituição financeira, contribuindo para a redução de riscos e taxas.

\subsubsection{Aspectos Jurídicos e Tributários}

A primeira legislação brasileira que tratou da diferenciação das empresas de menor porte foi a Lei $\mathrm{n}^{\mathrm{o}}$ 7.256, de 27 de novembro de 1984, que criou o Estatuto da Microempresa e instituiu "tratamento diferenciado, simplificado e favorecido, nos campos administrativo, tributário, previdenciário, trabalhista, creditício e de desenvolvimento empresarial" (BRASIL, LEI No $7.256,1984)$.

Quatro anos depois, em 1988, a Constituição Federal do Brasil tratou a diferenciação das MPEs como um princípio de ordem econômica em seu artigo 970, inciso IX e determinou o tratamento diferenciado no artigo 179 , transcrito a seguir:

\footnotetext{
Art. 179. A União, os Estados, o Distrito Federal e os Municípios dispensarão às microempresas e às empresas de pequeno porte, assim definidas em lei, tratamento jurídico diferenciado, visando a incentivá-las pela simplificação de suas obrigações administrativas, tributárias, previdenciárias e creditícias, ou pela eliminação ou redução destas por meio de lei. (BRASIL, Constituição da República Federativa do Brasil de 1988, 1988)
}

A Lei $n^{0} 8.864$, de 28 de março de 1994, mudou a definição de microempresa e incluiu a definição de "empresa de pequeno porte", termo mencionado na Constituição Federal anos antes. Essa lei não foi regulamentada por ter sofrido vetos presidenciais que descaracterizaram seu propósito (Casa Nova, 1996), o que limitou sua efetividade.

Em 5 de dezembro 1996, a Lei $n^{\circ} 9.317$ revogou alguns artigos das leis anteriores, alterou a definição das MPEs e instituiu o regime tributário simplificado para essas empresas, o Sistema Integrado de Pagamento de Impostos e Contribuições das Microempresas e das Empresas de pequeno Porte (SIMPLES). A Lei do Simples, como ficou conhecida, embora de âmbito federal, criou a possibilidade de que, por meio de convênios com Estados e Municípios, o Imposto Sobre Circulação de Mercadores e Serviços (ICMS) e o Imposto Sobre Serviços (ISS) fossem recolhidos juntamente ao SIMPLES. Porém, a efetividade desses 
convênios foi baixa, pois, como lembra Fabretti (2011, p.139) os "Estados e Municípios tinham se recusado a firmar esses convênios por razões políticas, ou seja, para não ficar na dependência da União de retardar o repasse dos recursos, preferindo continuar arrecadando diretamente os seus impostos".

Um novo Estatuto da Microempresa e da Empresa de Pequeno Porte foi instituído pela Lei $n^{\circ} 9.841$, de 5 de outubro de 1999. Esse instrumento legal revogou completamente as Leis $\mathrm{n}^{\mathrm{o}} 7.256 / 84$ e 8.864/94 e ampliou o número de empresas que poderiam ser enquadradas como MPEs, previsto na Lei $n^{0}$ 9.317/96. De acordo com Lima (2001, pp.424-425), os principais benefícios trazidos pelo novo Estatuto foram: a ampliação das faixas limites de faturamento para o enquadramento da MPE, permitindo que um número maior de empresas acessassem o regime tributário simplificado; a facilitação dos procedimentos de registro e oficialização; a introdução do conceito de fiscalização pedagógica nas fiscalizações do INSS e trabalhistas; a previsão de um investimento mínimo de $20 \%$ dos recursos federais em pesquisa, desenvolvimento e formação tecnológica às micro e pequenas empresas; e a concessão de mais crédito para a exportação.

Embora tenha trazidos os benefícios acima mencionados, a Lei do Simples (Leis $\mathrm{n}^{\mathrm{o}}$ 9.317/96 e $\mathrm{n}^{\circ}$ 9.841/99) manteve as mesmas faixas de receita bruta anual para enquadramento das MPEs, que permaneceram inalteradas entre $1^{\circ}$ de janeiro de 1997 e 31 de dezembro de 2005. Essa falta de atualização por nove anos, nas palavras de Fabretti (2011, p.140), "causou na prática grandes transtornos para as $\mathrm{MPE}$, obrigando muitos pequenos empresários a praticarem vários malabarismos, inclusive deixando na informalidade parte de suas receitas brutas, para não se submeterem à tributação mais onerosa, por mudança de faixa de tributação. "Os valores de receita bruta anual foram atualizados pela Lei $\mathrm{n}^{\circ} 11.196$ de 21 de novembro de 2005 , com vigor a partir de $1^{\circ}$ de janeiro de 2006.

A Lei do Simples foi completamente revogada pela Lei Complementar $n^{\circ} 123$ de 14 de dezembro de 2006 (LC 123/2006), a qual instituiu um novo Estatuto da Microempresa (ME) e da Empresa de Pequeno Porte (EPP), sendo também conhecida como Lei Geral da ME e EPP. Em função do seu caráter de Lei Complementar, de abrangência tributária nacional, incluiu na tributação unificada os tributos estaduais e municipais, bem como as obrigações acessórias (Fabretti, 2011). 
A LC 123/2006 em vigor hoje define como microempresa aquela com receita bruta anual anterior de até $\mathrm{R} \$ 360.000$ e empresa de pequeno porte aquela com até $\mathrm{R} \$ 3.600 .000$. Essa lei foi alterada pela Lei Complementar $n^{\circ}$ 147, de 7 de agosto de 2014 universalizando a possibilidade de opção pelo Simples a todas as atividades de profissão regulamentada a partir de janeiro de 2015.

$\mathrm{Na}$ esfera tributária, o contador é bastante utilizado. Uma grande parcela dos PAPNs percebe os contadores como provedores de serviços associados a obrigações físcais e trabalhistas (Miranda, Libonati e Freire, 2008). Porém, a maior contribuição da contabilidade para as MPEs nesse campo está no planejamento tributário. Batista, Freitas, Soares e Rêgo (2012) o desprezo por essa atividade foi fator que contribuiu fortemente para o encerramento das atividades das empresas estudadas em uma cidade paraibana.

\subsection{Os Proprietários-Administradores de Pequenos Negócios (PAPNs)}

Uma característica compartilhada por grande parte dos proprietários administradores das micro e pequenas empresas é a deficiência em competências administrativas. Em sua dissertação de mestrado, Casa Nova (1996) destacou:

É grande o número de empreendedores que, após criar sua empresa, passa a desempenhar um papel gerencial, seja a nível geral ou específico. No entanto, em muitos casos o empreendedor possui um conhecimento técnico da área em que pretende atuar, mas não tem a experiência de exercer um papel administrativo. Ou então ocupou cargos de gerência em empresas grandes ou médias, e agora pretende dirigir sua própria empresa. E se defronta então com problemas de administração de pessoal, produção, compras, capital de giro entre outros. (Casa Nova, 1996, p.97)

... Muitas vezes a decisão é tomada com base no sentimento. No caso de pequenas empresas familiares, frequentemente, os sucessores permanecem fazendo aquilo que aprenderam com seus pais sem entender mesmo o significado ou, o que é mais importante, os efeitos de mudanças ambientais nesses procedimentos administrativos. (Casa Nova, 1996, p.115)

Dyer e Ross (2007), em estudo canadense, destacam como características dos PAPNs o desejo por independência e autossuficiência, características que contribuem, muitas vezes, para que esse empresário demore a procurar ajuda externa, pois isso negaria essas “qualidades". Gooderham, Tobiassen, Doving e Nordhaug (2004) e Dalley e Hamilton (2000) ressaltam a preferência desse empresariado pela comunicação verbal e informal, sendo que Stone (2011) ampliou a constatação detectando que os contatos telefônicos são os meios preferidos para essa comunicação em função do baixo custo, seguida pela conversa face a face, que permite ajustes comunicacionais em função das pistas dadas pelos interlocutores no tom da fala, expressões faciais e postura. 
A denominação desse grupo de empresários suscita algumas confusões, uma vez que é comum encontrar tanto na literatura quanto na fala das pessoas o uso do termo empreendedor como sinônimo de proprietário de um pequeno negócio. Porém, Carland, Hoy, Boulton e Carland (1984) afirmam que ser proprietário de um pequeno negócio não implica necessariamente em ser empreendedor. Assim como não são necessariamente sinônimas uma firma empreendedora e uma pequena empresa. Para os autores, tanto o proprietário de pequeno negócio quanto o empreendedor são indivíduos que estabelecem e administram um negócio. A diferença entre ambos está no propósito desse negócio e na maneira como se relacionam com ele. O proprietário de pequeno negócio vê sua empresa como uma maneira de atender seus objetivos pessoais, além de tê-lo como principal fonte de renda e de consumo da maioria de seu tempo e recursos. Para o proprietário, o negócio é uma extensão de sua personalidade e está intrinsicamente ligado às necessidades e aos desejos de sua família. $\mathrm{O}$ empreendedor tem por principal propósito o crescimento e o lucro, é inovador e emprega práticas estratégicas na gestão do negócio (Carland et al., 1984). Para Filion (1999), “empreendedores têm 'sonhos realistas', ou visões, com cuja realização estão comprometidos. Operadores, por outro lado, simplesmente querem dar bom uso às suas habilidades de forma a ganhar a vida" (Filion, 1999, p. 18).

Essa sobreposição de termos ocorre no Brasil inclusive na legislação que buscou incentivar a formalização dos micro negócios os quais atuavam na informalidade, a partir da criação do Micro Empreendedor Individual (MEI) (BRASIL, 2006). No portal oficial de apoio ao MEI, sua definição aparece como "uma pessoa que trabalha por conta própria e que se legaliza como pequeno empresário" (BRASIL, Portal do Empreendedor).

No presente trabalho, será empregado o termo Proprietários-Administradores de Pequenos Negócios (PAPNs) para designar tanto os empreendedores quantos aos proprietários de uma microempresa ou uma empresa de pequeno porte.

\subsection{A Contabilidade e a Gestão das Micro e Pequenas Empresas}

A contabilidade é importante instrumento para a administração de organizações, independente do porte ou finalidade. No caso das MPEs, que vivenciam elevadas taxas de mortalidade, a contabilidade é muitas vezes negligenciada pelos PAPNs, indicando deficiência administrativa desses empresários ao não dar a devida importância a essa ferramenta de gestão. Longenecker et al. (1998) vinculam a falta de aptidão em sistemas 
contábeis a problemas financeiros e à falsa ideia de que os controles são desnecessários. Nas palavras desses autores:

Muitas empresas pequenas que se defrontam com problemas financeiros possuem registros contábeis inadequados. Os administradores e proprietários dessas empresas parecem pensar que têm menos necessidade de informações financeiras pelo fato de estarem envolvidos em todas as fases das operações do dia a dia. Esse tipo de convicção não só é incorreto, como é também perigosamente enganoso. (Longenecker et al., 1998, p.515)

A precariedade em sistemas de controles financeiros também é apontada por Raifur (2013) como comprometedora do desempenho dos negócios principalmente em situações em que há falta de recursos e sazonalidade das operações e receitas.

Dentre os achados de Riva (2013), está a baixa relação entre a qualidade da informação contábil gerada dentro dos padrões internacionais (CPC-PME) pelas PMEs e o custo do crédito concedido a essas empresas, ou seja, a afirmação de que a produção de demonstrações contábeis no padrão internacional reduziria custos de crédito não foi confirmada em seu estudo, ao menos no período estudado que corresponde aos primeiros anos da adoção da norma.

Ademais, Riva (2013) afirma que essa baixa relação entre informação contábil e redução no custo da concessão de crédito pode explicar a alta informalidade nas empresas menores, em suas palavras:

A principal contribuição deste trabalho é o exame da relação entre a qualidade das informações contábeis e o custo do crédito bancário, no âmbito das empresas de porte reduzido, assunto vagamente explorado no meio acadêmico. A pequena influência das informações contábeis nesse segmento, pelo menos nesse primeiro momento de mudanças nos padrões contábeis, no custo de crédito bancário, contribui para explicar o alto grau de informalidade nas PMEs. (Riva, 2013, pp.141-142)

Pode-se inferir, a partir da leitura da dissertação de Riva (2013), a existência de um possível círculo vicioso. De um lado, os bancos são rigorosos e cobram taxas elevadas das pequenas empresas porque essas não apresentam informações adequadas. De outro lado, as empresas menores não percebem que melhores relatórios financeiros contribuirão para a redução de taxas e isso contribuiu para o aumento ou manutenção da informalidade em termos de controles e sistemas contábeis.

Em sua dissertação de mestrado, Casa Nova (1996) debruçou-se sobre a relação da contabilidade com a pequena empresa e afirmou:

... o papel a ser desempenhado pelo contador na pequena empresa não difere grandemente daquele desempenhado na grande empresa. Poderíamos resumi-lo como a responsabilidade pela estruturação de um sistema de informações de apoio à decisão de forma a auxiliar a 
empresa na busca pela melhor utilização de recursos, ou seja, o alcance da eficácia empresarial. (Casa Nova, 1996, p.113)

Embora haja semelhança no papel desempenhado pelo contador e nos objetivos da contabilidade tanto na pequena quanto na grande empresa, a autora chama a atenção para a diferença na forma de atingi-los, uma vez que a pequena empresa enfrenta problemas específicos. A partir de sua experiência em trabalhos de consultoria para pequenas empresas junto ao extinto Laboratório de Pequenas Empresa (PMELab) do Departamento de Contabilidade da FEA/USP, Casa Nova (1996) listou algumas características básicas das informações contábeis para o atendimento das necessidades dos gestores dessas empresas, sendo elas: a simplicidade, a facilidade de obtenção, a relevância, a atualidade, a possibilidade de efetuar simulações e facilidade de manipulação das informações. Tomando essas características como premissa sugeriu um modelo de Fluxo de Caixa Prospectivo, caracterizado pela própria autora:

... [em] um novo papel a ser exercido pela Contabilidade. Mensurando, comunicando e constituindo-se em um sistema de informações gerenciais útil e confiável, respeitando as características específicas das pequenas empresas e pautando-se, portanto, na elaboração de relatórios, pela simplicidade, facilidade de obtenção das informações, relevância, atualidade, possibilitando ao gestor efetuar simulações e manipular as informações de forma simples. Alcançaria, assim, inicialmente, o objetivo singelo de conduzi-lo a um maior conhecimento do funcionamento de seu negócio. E, posteriormente, à compreensão de conceitos contábeis complexos como depreciação e provisões. (Casa Nova, 1996, pp.233-234)

Essa ferramenta proposta por Casa Nova (1996) é um instrumento bastante útil para o PAPN e o contador frente aos problemas apresentados anteriormente de captação de recursos, planejamento pré e pós-instalação do negócio, acompanhamento e simulação de cenários, análise de impacto das escolhas tributárias possíveis, todas essas possibilidades vistas pelo PAPNs em um único relatório, simples, considerando suas especificidades.

Marion (2006, p. 25) afirma que a "função da contabilidade é produzir informações úteis aos usuários da Contabilidade para tomada de decisões", porém, o autor ressalta que quando se trata da pequena empresa, "a função do contador foi distorcida (infelizmente), estando voltada exclusivamente para satisfazer às exigências do fisco.”

Embora a necessidade de uma boa comunicação por parte dos contabilistas seja reconhecida e citada em muitos trabalhos, como o de Silva e Marion (2013, p.11) no qual afirmam que o contabilista "precisa ser visto como um comunicador de informações essenciais à tomada de decisões, pois a habilidade em avaliar fatos passados, perceber o presente e predizer eventos futuros pode ser compreendida como fator preponderante ao 
sucesso empresarial", a comunicação é fonte de problemas na relação proprietário-contador como apontou Villa (2012), a partir de estudo de caso de múltiplas microempresas. Segundo a autora, a indisponibilidade do contador para dirimir dúvidas, a ausência de linguagem clara e simples, bem como o excesso do uso de jargões técnicos pelo profissional são fatores que prejudicam a comunicação entre ele e os PAPNs. A autora também verificou a existência de certa resistência por parte do empresariado em utilizar as informações contábeis, pois não consideram úteis para a tomada de decisão em suas empresas.

Em uma extensão da pesquisa anteriormente mencionada, Villa, Espejo, Casa Nova e Voese (2013) identificaram aspectos comportamentais que influenciam a compreensão e o uso da contabilidade gerencial na tomada de decisões das MPEs. Os problemas citados anteriormente foram reafirmados e complementados, como se nota a seguir:

A disponibilidade do contador em dirimir dúvidas dos empreendedores, linguagem clara e simples, redução do uso de jargões técnicos, aperfeiçoamento dos gestores com cursos de gestão e contabilidade mais próxima do dia a dia administrativo. Incluem-se, também, neste rol, a valorização da Contabilidade pelos próprios contadores, ao informar aos seus clientes sobre a importância de se ter dados relevantes e exatos para a tomada de decisão; juntamente com a valorização da Contabilidade pelos gestores da microempresa, ao perceberem o seu potencial informativo, desvinculando a imagem de Contabilidade apenas para fins fiscais. (Villa et al., 2013, p.15)

Villa et al. (2013) concluem o estudo chamando a responsabilidade ao contador de considerar o PAPN como parte integrante da mensagem contábil e buscar compreensão do mesmo.

Em pesquisa feita com pequenas empresas britânicas, Marriott e Marriott (2000) detectaram que naqueles pequenos negócios, cujas informações administrativo-contábeis eram geradas pelos próprios administradores-proprietários, havia deficiência nas informações, baixa consciência da importância da informação e, consequentemente, relutância em contratar serviços de contabilidade além daqueles burocráticos; porém, quando os contadores prestavam ao menos informações contábeis básicas, com uso de gráficos, os clientes melhoravam a percepção do valor da informação e aumentavam a propensão em contratar serviços de gestão contábil.

\subsubsection{Regulação Contábil}

Todas as empresas brasileiras são obrigadas a manter um sistema de contabilidade, mecanizado ou não. Essa obrigatoriedade é imposta pelo Código Civil brasileiro, em seu artigo 1.179: 
Art. 1.179. O empresário e a sociedade empresária são obrigados a seguir um sistema de contabilidade, mecanizado ou não, com base na escrituração uniforme de seus livros, em correspondência com a documentação respectiva, e a levantar anualmente o balanço patrimonial e o de resultado econômico (BRASIL, 2002).

O sistema contábil a ser mantido pelas empresas deve ser elaborado por contador legalmente habilitado, de acordo com o artigo 1.182 do Código Civil: "Sem prejuízo do disposto no art. 1.174, a escrituração ficará sob a responsabilidade de contabilista legalmente habilitado, salvo se nenhum houver na localidade". Desse modo, toda organização empresarial terá de contar, inevitavelmente, com o auxílio de um profissional contábil, inclusive o pequeno empresário, a quem a mesma lei garante, em seu artigo 970, determina tratamento simplificado: "A lei assegurará tratamento favorecido, diferenciado e simplificado ao empresário rural e ao pequeno empresário, quanto à inscrição e aos efeitos daí decorrentes".

Os profissionais de contabilidade são considerados legalmente habilitados "após a regular conclusão do curso de Bacharelado em Ciências Contábeis, reconhecido pelo Ministério da Educação, aprovação em Exame de Suficiência e registro no Conselho Regional de Contabilidade a que estiverem sujeitos", de acordo com o artigo 12 do Decreto-lei no 9.295 de 27 de maio de 1946, que criou o Conselho Federal de Contabilidade (CFC) e definiu as atribuições do Contador.

Toda organização empresarial deve ter um sistema de contabilidade mantido por um contabilista legalmente habilitado e esse deve seguir as Normas Brasileiras de Contabilidade editadas pelo $\mathrm{CFC}$, as quais estão em consonância com o padrão internacional das International Financial Reporting Standards (IFRS). Logo, a contabilidade de todas as organizações estará sujeita à regulamentação contábil, seja aquela expedida pela Comissão de Valores Mobiliários (CVM), para as sociedades anônimas e empresas de grande porte, seja a expedida pelo Banco Central ou Superintendência de Seguros Privados (SUSEP), no caso de financeiras, seguradoras e previdências privadas, seja por meio das Normas Brasileiras de Contabilidade, aplicáveis às demais empresas, dentre as quais, as MPEs.

As MPEs, que não têm obrigação pública de prestação de contas e não optaram pela adoção completa dos pronunciamentos do $\mathrm{CPC}$, aprovados na totalidade pelo $\mathrm{CFC}$, deverão seguir o Pronunciamento Técnico PME, correlato ao The International Financial Reporting Standard for Small and Medium-sized Entities (IFRS for SMEs) do IASB. Esse pronunciamento foi aprovado e editado pelo Comitê de Pronunciamentos Contábeis (CPC) 
em dezembro de 2009 e aprovado pelo CFC no mesmo mês por meio da Resolução CFC no 1.055/05, que o converteu na 'NBC TG 1000 - Contabilidade para Pequenas e Médias Empresas' com aplicação obrigatória a partir de 2010. Essa norma representa uma simplificação das IFRS completas e sua adoção colocou o Brasil à frente de muitos outros países no processo de convergência ao padrão contábil internacional para Pequenas e Médias Empresas (Riva, 2013).

A obrigatoriedade do padrão internacional às PMEs, que são os principais clientes dos contadores e escritórios contábeis, trouxe grandes desafios principalmente à classe. Um deles, como explicitado por Relvas, Bertholini e Segato (2010), “é passar a lidar com normas baseadas em princípios e que sobrepõem a essência (econômica) sobre a forma (jurídica)" (p.11), mudança que exige atualização técnica, mas, principalmente, reciclagem na maneira de pensar dos contabilistas.

Os autores defendem que a adoção do padrão internacional pelas Pequenas e Médias Empresas (PMEs) pode reduzir custos de captação de recursos:

As pequenas e médias empresas, ao adotarem as novas normas, pelas quais a essência deve-se se sobrepor à forma, terão informações contábeis de maior qualidade para fornecerem a seus credores, por exemplo. E informações de qualidade e confiáveis podem reduzir os custos de captação, na medida em que permitem reduzir os níveis de incerteza. (Relvas et al., 2010, p.7)

Porém, Riva (2013), em sua dissertação de mestrado, estudou se a adoção do padrão contábil internacional pelas PMEs reduziria o custo do crédito e constatou que apenas "em empresas com maior tamanho em receita, os benefícios em custos de captação bancários ficam mais evidentes" (Riva, 2013, p. 144)

Relvas et al. (2010) também advogam que a adoção da norma traz benefícios para a gestão como um todo:

É fato que uma grande parte das pequenas e médias empresas tem deficiência informativa também para fins de gestão, o que as tornam vulneráveis, principalmente nos momentos de retração do mercado. Com um maior domínio sobre aspectos chave de seus negócios (custos, contingências, riscos etc.), elas estariam mais capacitadas para reagir rapidamente às condições adversas de mercado ou às oportunidades que possam surgir, garantindo maiores chances de sucesso e evitando a descapitalização da empresa ou até mesmo o seu fechamento.... Como se pode perceber, a utilização dos novos padrões contábeis apresenta inúmeras vantagens para as PMEs, inclusive para melhorar a qualidade das informações para fins de gestão. (Relvas et al., 2010, p.11)

Entretanto, na revisão de literatura sobre a necessidade de estabelecimento de um padrão contábil internacional para as PMEs feita por Riva (2013), o autor encontrou questionamentos a respeito: da desproporcionalidade de custos de implementação de um novo 
padrão; da capacidade técnica dos contadores dessas empresas e dos demais stakeholders para interpretar e julgar normas baseadas em conceitos e princípios; da real necessidade de comparabilidade de demonstrações financeiras; e da identificação dos usuários das informações contábeis e suas necessidades, bem como as questões envolvendo o tamanho das pequenas empresas, especialmente para as microempresas, e a influência da legislação tributária.

Sobre a obrigatoriedade da adoção da norma pelas PMEs, Riva (2013, p.141) entende que "os custos com adaptação ao novo padrão (pessoal qualificado, sistemas, processos, etc.) podem ser muito heterogêneos entre as empresas deste setor, ou seja, o que é pouco para algumas, pode ser muito para outras" e, assim como os seus entrevistados, defende a adoção de forma voluntária para esse grupo de empresas, as quais fariam suas próprias análises de custo-benefício "na medida em que elas percebessem ganhos com a divulgação de informações".

Uma vez que a norma internacional tem foco no usuário externo, especialmente credores, no caso das PMEs brasileiras, pode-se concluir que o cumprimento de suas exigências, além de dispendiosa, pode não atender as necessidades dos PAPNs na gestão do negócio, colocando em xeque o princípio da relação custo-benefício presente na própria norma.

Embora pretenda ser uma opção simplificada à aplicação dos pronunciamentos técnicos completos do CPC, a NBC TG 1000 ainda é bastante complexa para a realidade daquelas empresas menores. Atento a essa questão, o CFC, por meio da Resolução CFC n ${ }^{\circ}$ 1.418/12, aprovou em dezembro de 2012 a ITG 1000 - Modelo Contábil para Microempresa e Empresa de Pequeno Porte, aplicável, a partir de $1^{\circ}$ de janeiro de 2012, às MPEs com receita bruta anual, no ano calendário anterior, até os limites previstos nos incisos I e II do Art. $3^{\circ}$ da Lei Complementar no 123/06, ou seja, R\$3.600.000.

O ITG 1000 é uma norma simplificada, composta por apenas cinco páginas de sete itens sobre escrituração, 11 itens sobre critérios e procedimentos contábeis, 15 itens sobre as demonstrações e três itens sobre um plano de contas simplificado. A norma também prevê a possibilidade de partidas mensais dos lançamentos contábeis e dá a opção de elaborar ou não a Demonstração do Fluxo de Caixa e a Demonstração das Mutações do Patrimônio Líquido, sendo obrigatória a elaboração do Balanço Patrimonial e da Demonstração do Resultado do 
Exercício. Além disso, o ITG 1000 traz um modelo de Carta de Responsabilidade da Administração que deve ser assinada pelos PAPNs com o intuito de salvaguardar as responsabilidades do Contador quanto a veracidade das informações fornecidas pelos clientes.

Apesar da obrigatoriedade de manter um sistema de contabilidade, o setor de fiscalização do Conselho Regional de Contabilidade do Estado de São Paulo (CRC-SP) estima que 80\% das MPEs não tem escrita contábil (David Filho, 2013). Esse dado sugere que: (a) as normas contábeis não têm sido adotadas mesmo antes da conversão ao padrão internacional, (b) possivelmente essas MPEs tenham serviços contábeis contratados apenas para o atendimento de serviços fiscais e burocráticos e (c) se contadores estão prestando apenas serviços fiscais, deixando de realizar a escrituração contábil a esses clientes, podem estar contrariando sua função prevista nas normas da classe e exigida às MPEs pela CF.

\subsubsection{Formação dos Contadores}

Como lembrou Casa Nova (1996, pp.33-34), na década de 1990, quando vigorava a Resolução no 3, de 1992, do Conselho Federal de Educação (CFE), os cursos de graduação em Ciências Contábeis não traziam disciplinas voltadas especificamente para a Contabilidade das MPEs. Atualmente, a Resolução no 10, de 2004, da Câmara de Ensino Superior do Conselho Nacional de Educação institui diretrizes curriculares nacionais do curso de forma mais abrangente, mencionando em seu artigo $3^{\circ}$ :

O curso de graduação em Ciências Contábeis deve ensejar condições para que o futuro contabilista seja capacitado a:

I - compreender as questões científicas, técnicas, sociais, econômicas e financeiras, em âmbito nacional e internacional e nos diferentes modelos de organização;

II - apresentar pleno domínio das responsabilidades funcionais envolvendo apurações, auditorias, perícias, arbitragens, noções de atividades atuariais e quantificações de informações financeiras, patrimoniais e governamentais, com a plena utilização de inovações tecnológicas;

III - revelar capacidade crítico-analítica de avaliação, quanto às implicações organizacionais com o advento da tecnologia da informação.

Embora a diretriz acima determine a compreensão das questões científicas, técnicas, sociais, econômicas e financeiras de diferentes modelos de organização, o que pressupõe, inclusive, diferentes portes, as disciplinas específicas voltadas para a Contabilidade da MPEs ainda são raras ou ausentes, como é o caso, por exemplo, do curso na Faculdade de Economia, Administração e Contabilidade (FEA) da Universidade de São Paulo (USP), cuja grade curricular vigente não contempla disciplinas com esse enfoque, inclusive no caso das disciplinas não obrigatórias (eletivas). 
Riva (2013), afirma que a adoção voluntária das normais internacionais de contabilidade às PMEs, ressalta o impacto da obrigatoriedade das IFRS na formação do contabilista:

Uma vez que o uso de um novo padrão de contabilidade que atinge a maior parte dos ramos da economia nacional, certamente deveria envolver investimento em ensino contábil. A capacitação em IFRS seria de fundamental importância para a promoção da educação dos atuais profissionais, dos professores de contabilidade e dos futuros estudantes, para a devida adequação dos interessados aos padrões contábeis internacionais (p.15)

Dyer e Ross (2007) lembram que embora os cursos de contabilidade tenham um enfoque prático, eles formam alunos em um sistema formal de regras e procedimentos, incentivando habilidades técnicas, análises, especialização e de tomada de decisão racional:

Programas em legislação e formação de profissionais de contabilidade não são muito diferentes em termos de conteúdo ou forma. Embora eles tendam a serem mais orientados à prática, esses programas ensinam um sistema formal de regras e procedimentos, incentivando habilidades técnicas, análises, especialização e de tomada de decisão racional. Assim, o consultor de negócio típico com um curso de graduação ou de pós-graduação é um especialista em uma área funcional particular, com uma propensão à análise de informações técnicas e a tirar conclusões racionais defensáveis sobre um curso de ação preferido. [Tradução livre] ${ }^{1}$. (Dyer e Ross, 2007, p.133)

Essa formação orientada para a racionalidade analítica pode ser um dificultador para o contador quando decide atuar como consultor das MPEs, uma vez que os PAPNs preferem um estilo de comunicação mais informal (Dyer e Ross, 2007).

A formação do profissional de contabilidade passou por recente alteração, estabelecida pela Lei $\mathrm{n}^{\mathrm{o}} 12.249$ de 2010, que alterou o Decreto-lei $\mathrm{n}^{0} 9.295$ de 1946, o qual define as atribuições do Contador. De acordo com a nova redação da legislação, a formação técnica em contabilidade será assegurada até $1^{\circ}$ de junho de 2015. Após essa data, somente serão habilitados os profissionais com formação superior, extinguindo-se o curso técnico que tinha duração de um ano. É comum escutar de educadores da área a afirmação de que essa mudança é positiva, pois o curso superior é mais longo, cinco anos, o que permite o aprofundamento em temas contábeis, além de englobar disciplinas multidisciplinares, que são essenciais para a atuação do contador hodierno. Porém, os efeitos que essa mudança pode ter na futura geração de profissionais da classe devem ser acompanhados e pesquisados no futuro, fazendo dessas afirmações apenas expectativas ou achismos.

\footnotetext{
${ }^{1}$ Programmes in law and training for professional accounting designations are not dissimilar in content or form. Though they tend to be more practically oriented, these programmes teach a formal system of rules and procedures, encouraging technical skills, analysis, specialization and rational decision-making. Thus the typical business advisor with an undergraduate or postgraduate degree is an expert in a particular functional area, with a proclivity for analysing technical information and drawing rational defensible conclusions about a preferred course of action. (Dyer e Ross, 2007, p.133)
} 


\subsection{A Consultoria às Micro e Pequenas Empresas}

As mudanças mercadológicas, os incessantes avanços tecnológicos e os clientes cada vez mais exigentes impõem às empresas desafios constantes. Para Concistré (2012), esse cenário faz com que as empresas terceirizem todas as atividades sem caráter permanente ou contínuo, nascendo assim a atividade de consultor. Mas, afinal, o que é consultoria?

Schein, um dos primeiros autores a tratar do assunto, denominou consultoria com "um conjunto de atividades desenvolvidas pelo consultor, que ajudam o cliente a perceber, entender e agir sobre fatos inter-relacionados que ocorrem em seu ambiente" (Schein, 1972, p.8).

Sobre o consultor, Block (2011) enfatiza a distinção entre o papel desse profissional e o do administrador da empresa, para o autor:

Um consultor é uma pessoa em uma posição de ter alguma influência sobre um indivíduo, um grupo ou uma organização, mas não tem poder direto para fazer alterações ou implementar programas. Um gerente é alguém que tem responsabilidade direta sobre a ação². [Tradução livre] (Block, 2011, capítulo 1, acesso on line)

Maister, Green e Galford (2000, como citado por Dyer e Ross,2007) defendem que a consultoria atrai pessoas com personalidades mais racionais. Porém, afirmam-se chocados com as sugestões, presentes na literatura, de que os consultores estão totalmente desfamiliarizados com o emocional ou o informal, já que eles lutam, por vezes, para manter a expertise demandada pelos clientes cada vez mais exigentes. E, principalmente os consultores de pequenos escritórios, precisam cultivar a arte da comercialização de seus serviços, inspirando confiança, para garantirem a própria sobrevivência a longo prazo. Essa dicotomia entre o consultor racional, tecnocrata e formal versus o PAPNs intuitivo e 'burlador de regras' é criticada por Dyer e Ross (2007) para quem a literatura sobre o assunto ainda é bastante parca.

Schein (1995), quem cunhou o termo e o conceito de "process consultation", retoma o assunto em artigo no qual buscou sintetizar a definição e esclarecer as diferenças entre o "process consultation", "action research" e "clinical inquiry". Nesse trabalho o autor relembra as suposições e valores do "process consultation":

\footnotetext{
${ }^{2}$ A consultant is a person in a position to have some influence over an individual, a group, or an organization but has no direct power to make changes or implement programs. A manager is someone who has direct responsibility over the action. (Block, 2011, capítulo 1, acesso on line)
} 
(1) Apenas o cliente sabe o que, em última análise, ele ou ela pode fazer, vai fazer, e quer fazer, portanto, o objetivo estratégico do processo de consultoria deve desenvolver um processo que transforme o consultor e o cliente em uma equipe que possuirá todas as intervenções.

(2) É trabalho do consultor/auxiliar educar o cliente através das primeiras intervenções sobre as possíveis consequências de intervenções posteriores.

(3) Tudo o que o consultor faz desde as primeiras respostas às indagações iniciais do cliente, é uma intervenção. O consultor deve, portanto, ser altamente consciente das consequências de diferentes "diagnósticos" de intervenções ${ }^{3}$. [tradução livre] [ênfase adicionada] (Schein, 1995, p.18)

No âmbito do papel de educador do profissional durante o processo de consultoria, Dalley e Hamilton (2000) estudaram o significado do contexto das MPEs e sua influência na construção do conhecimento e do aprendizado dessas empresas, bem como o impacto do contexto na efetividade do treinamento e educação das MPEs. Os autores apontam que a transferência de conhecimento só ocorre quando há compatibilidade de contexto entre o provedor da informação e o receptor da mesma, em suas palavras:

Para que a transferência de conhecimento ocorra, é necessário que haja um nível relativamente elevado de compatibilidade de contexto entre o provedor de informações e receptor na pequena empresa. Novos conhecimentos serão incorporados no contexto e modificá-lo. É neste ponto que pode se dizer que a "aprendizagem" ocorreu ${ }^{4}$. [tradução livre] (Dalley e Hamilton, 2000, p.52)

De acordo com os autores, pode-se esperar que o proprietário da pequena empresa seja não racional, subjetivo e emocional nas suas interações com o ambiente externo e essas características são particularmente desafiadoras para os consultores que, compreensivelmente, tentam formular soluções objetivas e racionais através de métodos analíticos genéricos. Ademais, os proprietários desses negócios acreditam fortemente na singularidade de seus empreendimentos, o que os torna muito circunspectos frente a novas informações ou conselhos, não importando quão bem-intencionados ou eficazes sejam esses (Dalley e Hamilton, 2000, p.57).

Dalley e Hamilton (2000) lembram que muitos consultores atuam ou atuaram em grandes empresas de consultoria com elevada estrutura burocrática em seus processos. Porém, esse cenário distancia-se daquilo procurado pelos PAPNs, os quais esperam encontrar, nas

\footnotetext{
${ }^{3}$ (1) Only the client ultimately knows what he or she can do, will do, and wants to do, hence the strategic goal of process consultation must be to develop a process that will build the consultant and client into a team that will own all the interventions.

(2) It is the job of the consultant/helper to educate the client through the early interventions on the potential consequences of later interventions.

(3) Everything the consultant does, from the earliest responses to the client's initial inquiries, is an intervention. The consultant must therefore be highly aware of the consequences of different "diagnostic" interventions. (Schein, 1995, p.18)

${ }^{4}$ for knowledge transfer to occur, there needs to be a relatively high level of context compatibility between the provider of information and the small business recipient. New knowledge will be incorporated into the context and modify it. It is at this point that 'learning' can be said to have occurred. (Dalley e Hamilton, 2000, p.52)
} 
palavras dos autores, "um aliado, alguém de confiança com quem possam compartilhar um fardo e, assim, reforçar o conhecimento do núcleo do negócio5". Ademais, cabe aos consultores a tarefa de adaptar-se ao contexto, ao estilo de aprendizagem e às preferências comunicacionais dos seus clientes PAPNs e concluem:

O desafio fundamental para os consultores e a chave para sua eficácia na área de pequenos negócios é ser capaz de transformar a si e seus conhecimentos em formatos compatíveis com a empresa de pequeno porte. Qualquer conselho que entre em conflito com a cultura, os modos de comunicação e estilos de aprendizagem está destinado a ser ineficaz. Para minimizar conflito, consultores devem estar preparados para mergulharem no contexto das pequenas empresas a fim de entendê-las de dentro para fora. Se isso não for feito, uma tensão se desenvolverá entre proprietário e consultor. Isso pode então progredir para uma luta por poder e um inevitável fracasso da relação ${ }^{6}$. [tradução livre] (Dalley e Hamilton, 2000, p.59).

Dyer e Ross (2007) também destacaram que muitos consultores aprenderam seu ofício em um contexto muito distinto da realidade dos PAPNs e poucos deles têm experiência na administração de um negócio. Os autores afirmam que os gerentes de bancos, os contadores e outros assessores tentam forçar os PAPNs a se adaptarem às suas próprias maneiras de pensar, o que resulta em uma relação destinada ao fracasso, a contramão da assertiva de Dalley e Hamilton (2000) sobre a adaptação ao cenário do cliente. Além disso, esses consultores oriundos de grandes empresas de consultoria trabalham dentro de um roteiro de trabalho claro que governa seu dia a dia, muito mais regulado que o ambiente típico dos PAPNs, mesmo quando o consultor trabalha individualmente, pois, frequentemente, deve seguir as regras do seu conselho de classe (Dyer e Ross, 2007).

Uma das características da consultoria é o domínio de determinado assunto. Tanto o consultor quanto o cliente assumem que o valor do consultor está no domínio do conteúdo (Dyer e Ross, 2007). De acordo com Maister, Green e Galford, autores do livro 'The Trusted Advisor', publicado em 2000 e citado por Dyer e Ross, a internet permitiu que os clientes tivessem acesso rápido a conteúdos ampliando suas bases de conhecimento, o que aumentou a pressão por conteúdo sobre o consultor profissional, quem precisa mostrar resultado para problemas imediatos. Situação análoga à vivenciada pelos médicos, por exemplo.

\footnotetext{
${ }^{5}$ an ally, someone trustworthy with whom they can share a burden and thereby bolster the core knowledge of business

${ }^{6}$ The fundamental challenge to advisers, and the key to their effectiveness in the small business arena, is to be able to transform themselves and their knowledge into forms that are compatible with the small business. Any advice that conflicts with the culture, communication modes, and learning styles is destined to be ineffective. To minimize conflict advisers must be prepared to immerse themselves in the small business context in order to understand this from the inside out. If this is not done then tension will develop between the owner-proprietor and the adviser. This can then progress to a convert power struggle and inevitable failure of the relationship.
} 
A comunicação e a confiança, tal como na medicina, são fatores imprescindíveis na relação de consultoria. Bennett e Robson (1999), em uma pesquisa na Grã-Bretanha com 2.547 respondentes de PMEs, constataram que a consultoria é largamente dependente da relação de confiança entre consultor e cliente e que os consultores com maior nível de especialização e regulação profissionais são os mais usados, no caso da Grã-Bretanha: contadores, advogados e bancos. Os autores acreditam que, apesar dos achados serem referentes ao cenário britânico, “o padrão geral das relações entre consultores e seus clientes devem ser semelhantes em outros países $7 \%$. Gooderham et al. (2004) afirmam que a confiança é fator importante para o sucesso da consultoria em função dessa ser um tipo de serviço específico de negócios com um produto intangível.

No âmbito da comunicação, Stone (2011) constatou que conversas telefônicas e face a face são os métodos comunicacionais preferidos pelos PAPNs australianos. Seus achados estão em consonância com estudos anteriores e em outros contextos (Dyer e Ross, 2007; Dalley e Hamilton, 2000).

Gooderham et al. (2004), em uma pesquisa sobre os contadores como fonte de consultoria das empresas de pequeno porte norueguesas, constataram que a qualidade da relação entre contador e PAPNs precede a expansão dos serviços tradicionais dos escritórios contábeis para a consultoria. A partir desse trabalho, Dyer e Ross (2007) realizaram uma pesquisa exploratória com intuito de entender o que explicaria a qualidade na relação entre consultor e PAPNs, tendo como instrumento de coleta de dados entrevistas com diversos consultores de MPEs. Seus achados indicaram que a consultoria tem um ciclo de vida com começo meio e fim. No começo da relação ambos, consultor e PAPNs, têm de se conhecerem. O primeiro tem de descobrir as especificidades das atividades da pequena empresa e seus problemas para talhar seu conhecimento às necessidades daquele negócio, enquanto o segundo precisa apresentar os problemas do negócio apropriadamente e decidir como incorporar o conhecimento do consultor em suas decisões. Os obstáculos enfrentados pelos consultores profissionais nessa fase são as diferenças de mentalidade entre o consultor e os PAPNs, a falta de abertura de informações dos PAPNs ao consultor e os estereótipos em torno do trabalho do consultor. Se esses obstáculos forem vencidos e os resultados da consultoria forem positivos, a relação persistirá (Dyer e Ross, 2007).

\footnotetext{
${ }^{7}$ the general pattern of relationships between advisors and their clients should be similar in other countries.
} 
Os autores sugerem que a relação bem-sucedida tende a perdurar e a melhorar com o tempo. Porém, mesmo nas relações maduras entre o consultor e o PAPNs podem surgir problemas:

O empresário da empresa de pequeno porte pode decidir que o custo de serviços continuados ou a ligação contínua com o consultor tem mais ônus que benefícios. Em outras ocasiões, tendo trabalhado com sucesso em problemas de negócios específicos, o proprietário está agora à procura de um tipo diferente de consultoria. Nessas circunstâncias, o proprietário vai querer terminar o relacionamento consultivo e seguir sozinho ou começar um relacionamento com um novo consultor ${ }^{8}$. [tradução livre]. (Dyer e Ross, 2007, p.142)

Além do ciclo de vida da relação de consultoria, se inicial, maduro ou em declínio, Dyer e Ross também observaram que o estágio de desenvolvimento da MPE é fator importante para a qualidade da relação entre consultor e PAPNs. O consultor enfrentará problemas diferentes dependendo do estágio empresarial da MPE, se nascente, em crescimento ou em declínio. Em empresas nascentes, o foco do consultor é dizer ao empresário o que é ou não possível fazer e o problema enfrentado pelo consultor é a resistência dos PAPNs originada pela cultura de independência. Na empresa em crescimento, quando problemas começam a diminuir o desempenho da empresa, o serviço de consultoria é procurado ou retomado. Porém, normalmente com um atraso que pode exacerbar as dificuldades. Essa demora em buscar ajuda de um consultor é explicada pelos autores em função da "falta de conhecimento, sensibilidade ao preço [da consultoria], responsabilização do consultor, medo do fracasso e existência de uma história de sucesso anterior" (Dyer e Ross, 2007, p.144). Os pesquisadores afirmam que nas MPEs em declínio, o peso da intervenção do consultor dependerá do tamanho do problema enfrentado pela empresa e da pressão da crise, bem como os mesmos problemas comuns a empresas nascentes, serão encontrados pelo consultor nesse estágio.

Dyer e Ross (2007) constataram que as razões para o término da relação de consultoria são os mesmos encontrados na perspectiva do ciclo de vida da relação apresentados anteriormente. Concluem, por fim, que o processo de consultoria é dinâmico, pois, os relacionamentos evoluem assim como as empresas e essas evoluções impactam a qualidade da relação consultor-PAPNs.

\footnotetext{
${ }^{8}$ The small business owner may decide that the cost of continued services, or a continuing link with the advisor, is more burden than benefit. At other times, having successfully worked on specific business problems, the owner is now looking for a different kind of advising experience. In these circumstances, the owner will want to end the advisory relationship and go it alone, or start a relationship with a new advisor. (Dyer e Ross, 2007, p.142)

${ }^{9}$ lack of knowledge, price sensitivity [of consulting], blaming the advisor, fear of failure, and having a history of success
} 
As razões que levariam uma organização a buscar consultoria externa seriam: o enxugamento de sua estrutura, com organogramas cada vez mais "magros"; o alto custo de manutenção de profisssional altamente especializado; e a necessidade de um olhar externo à empresa, uma visão "oxigenada", com o consultor atuando como especialista, mão-de-obra ou facilitador (Concistré, 2012).

Dentro dessa mesma temática, Padula (1996, p.30-31) revisitou o estudo feito pela consultoria francesa Bernand Julhiet, o qual demonstrou que no mercado francês havia quatro aspectos determinantes para que uma Pequena ou Média Empresa contratasse uma consultoria externa: o tamanho, o setor de atuação, a estrutura da empresa e o perfil do dirigente. De acordo com o estudo citado por Padula (1996), as PME com mais de 70 empregados, atuantes em setores com alta tecnologia e em fase de crescimento e expansão eram mais propensas à contratação de consultoria externa. O autor conclui a partir dessa análise que "o sucesso de uma intervenção de consultoria será fortemente dependente da capacidade do consultor em identificar as motivações do dirigente e em modular proposições conforme as suas expectativas".

No Brasil, um dos grandes parceiros e consultores, em nível nacional, do pequeno empresário é o SEBRAE. Criado em 1972, a entidade nasceu com o objetivo inicial de apoiar a pequena e média empresa, mas, na década de 1990, após tornar-se um serviço social autônomo, teve seu foco deslocado para a micro e pequena empresa, tal como hoje é conhecido (Donadone, Silveira, e Ralio, 2012).

Segundo Donadone et al. (2012), a contratação pelo SEBRAE de profissionais que possuíssem conhecimentos acadêmicos em diferentes áreas de gestão favoreceu a aproximação entre as pequenas empresas e a consultoria, principalmente porque a instituição não se limitou a confecção de produtos físicos informativos, mas também ofereceu palestras, cursos e outras formas de consultoria coletiva, processo chamado pelos autores de 'massificação da consultoria'. A maior atribuição dos profissionais contratados pelo SEBRAE foi a "adaptação do ferramental acadêmico e das soluções gerenciais para o ambiente das pequenas empresas ... dado que a maior parte da literatura desenvolvida dentro das escolas de administração de empresas é voltada para o segmento das grandes organizações" (Donadone et al., 2012, p. 166). 


\subsubsection{A Consultoria Contábil às Micro e Pequenas Empresas}

Em sua dissertação de mestrado, Silvia Casa Nova apresentou a reflexão do Professor Masayuki Nakagawa sobre o significado da palavra Contabilidade a partir de consultas a dicionários. Segundo o Professor, a palavra remonta ao verbo contar, que conduz a significados ligados ao quantificar, como o mensurar e o calcular, mas o verbo também remete ao comunicar (contar a alguém) e ao confiar (contar com alguém) (Casa Nova, 1996, p.160). A comunicação e a confiança estão fortemente vinculadas à atividade de consultoria, especialmente no caso das MPEs (Bennett e Robson, 1999; Gooderham et al., 2004).

Muitos estudos internacionais apontam os contabilistas como profissionais que mais assessoram os pequenos empresários e a categoria profissional idealmente posicionada para atender às necessidades de consultoria do segmento. Na Grã-Bretanha, por exemplo, os contadores são a fonte mais frequente de consultoria entre as PMEs (83\%) e, juntamente com os clientes, são a fonte externa com maior impacto nos negócios (Carter et al., 2006; Berry, Sweeting e Goto, 2006; Gooderham et al., 2004; Jay e Schaper, 2003; Bennett e Robson, 1999).

O relatório 'Developing the business and developing people: the view of small firms' desenvolvido por Carter et al. (2006, p.13), no Reino Unido, “contadores continuam a ser a fonte de consultoria empresarial mais utilizada; quase três quartos dos entrevistados [74,1\%, sendo $82 \%$ na Irlanda do Norte] consultaram um contador no ano anterior ${ }^{10 \%}$ e a maioria (59\%) dos contratantes estão satisfeitos com os serviços prestados pela classe. Apesar dos números positivos, a pesquisa sinalizou uma queda no contentamento com o serviço: em 2002, 68\% dos clientes estavam satisfeitos, em 2000 o percentual era de $65 \%$. Bennett e Robson (1999, p.166), em pesquisa anterior também apontaram os contadores como "os profissionais especializados que são, de longe, a fonte mais frequente de consultoria externa $^{11}$, , procurado por $82 \%$ das 2.547 PMEs pesquisadas.

Em outro estudo em território inglês, dessa vez, circunscrito à cidade de Manchester, feito por Berry at al. (2006), o contador aparece como fonte de consultoria de $85 \%$ dos proprietários de pequenas empresas. Segundo os autores, o grau de utilização dos serviços de consultoria está positivamente relacionado com a taxa de crescimento das PMEs. Berry at al. (2006) advogam que contadores, os quais possuem uma relação única com o negócio de seus

\footnotetext{
${ }^{10}$ accountants remain the most frequently used source of business advice; nearly three quarters of respondents have consulted an accountant within the previous year

${ }^{11}$ the specialist professionals are by far the most frequent source of external advice
} 
clientes, também podem atuar como mentores dos proprietários-gerentes em questões gerais de gestão, planejamento e controle, incluindo a gestão de custos.

Jay e Schaper (2003) investigaram os fatores que levam os microempresários australianos, especificamente aqueles atuantes em 'home offices' - os quais são a maioria das microempresas naquele país, segundo os autores - a buscarem consultoria externa. A pesquisa constatou que $94 \%$ dos empresários pesquisados procuraram o contador como primeiro recurso de consultoria. Além disso, fatores como idade da firma, a idade e o gênero do principal proprietário e número de empregados da empresa afetam a busca por serviços de consultoria.

Segundo Gooderham et al. (2004), na Noruega, os pequenos escritórios de contabilidade são os principais conselheiros dos PAPNS pelas seguintes razões:

1) As MPEs são a principal base de clientes desses escritórios;

2) As pequenas empresas estão dispostas a pagar mais por serviços de consultoria do que serviços tradicionais de contabilidade;

3) A longevidade das relações (Marriott e Marriott, 2000) que permitem o desenvolvimento de confiança (Bennett e Robson, 1999);

4) A profissão contábil é fonte de regulação e essa característica aumenta a confiança dos PAPNs no consultor contábil.

No caso brasileiro, uma pesquisa realizada pelo Vox Populi em parceria com o SEBRAE-SP também apontou os contabilistas com fonte de consultoria das MPEs constituídas em 2005, ficando o próprio SEBRAE em segundo lugar, com o equivalente à metade da proporção dos contadores consultores (Vox Populi, 2007). Esse resultado indica que os contadores já são percebidos pelos PAPNs, de certa forma, como consultores, fato que pode ser explorado como uma oportunidade para a categoria profissional de expandir serviços e carteira de clientes.

O IFAC, ao revisar a literatura sobre o papel do contador como consultor das PMEs, apontou três motivações ou razões para que o proprietário-administrador busque aconselhamento no profissional de contabilidade: a competência técnica, a confiança e proximidade e capacidade de resposta (IFAC, 2010). 
Para Miranda, Libonati e Freire (2008), o contexto de preocupação constante com a economia de recursos das MPEs é fator de busca pelo contador, o qual "pode exercer importante papel, quase sempre, como consultor que terá a responsabilidade de orientar o administrador a tomar decisões nas diversas áreas do empreendimento” (p.134).

Para atuar como consultor, o contador precisa exercer atividades e ter desenvoltura diferentes daquelas normalmente suficientes para o cumprimento de obrigações societárias e fiscais. O IFAC (2010), no relatório 'The The Role of Small and Medium Practices in Providing Business Support to Small-and Medium sized Enterprises', elaborado após extensa revisão de literatura e entrevistas com seis contadores de diferentes partes do mundo, apresentou competências que contador precisa desenvolver para atuar como peça-chave da PME, são elas:

- Comunicação clara, acessível e, principalmente, verbal;

- Capacidade de entender o negócio do cliente como um todo, a fim de captar quais serviços fora do escopo tradicional podem ser oferecidos;

- Capacidade de venda dos serviços que estão além do conhecimento geral dos clientes sobre sua atuação;

- Atuação com rigor e ética;

- Disponibilidade para contatos.

Além disso, o contador precisa desenvolver habilidades interpessoais que permitam o estabelecimento de empatia com os clientes e a sua atuação como um treinador efetivo (IFAC, 2010, p. 26).

Outros desafios foram mencionados, o relatório do IFAC também concluiu que quanto maior a distância entre os serviços técnicos contábeis tradicionais, aqueles de cunho tributário e estatutário, os chamados 'noncompliance services' e a consultoria oferecida, maior terá de ser a habilidade dos contabilistas no convencimento de seus clientes de suas competências para essa atividade, pois também competirão com outras fontes de consultoria. Por fim, buscar a proximidade geográfica de seus escritórios com as PMEs aumenta a capacidade de resposta dos contadores consultores, uma vez que esse empresariado prefere o relacionamento face a face (Stone, 2011; IFAC, 2010; Dalley e Hamilton, 2000).

Marriott e Marriott (2000) afirmam que os serviços tradicionais contribuem para que os clientes enxerguem o profissional contábil como alguém confiável e podem representar 
uma janela de oportunidade para expansão dos serviços à consultoria. Nesse caso, os contadores brasileiros têm um grande mercado a ser explorado já que $80 \%$ das MPEs não tem contabilidade societária (David Filho, 2013).

No âmbito da satisfação dos PAPNs com a contabilidade, Gooderham et al. (2004) afirmam que essa independe do tempo da relação, sendo a qualidade dos serviços o fatorchave: "a satisfação da pequena empresa com seu contador é, na verdade, independente da duração da relação. Portanto, a confiança parece ser mais um resultado da qualidade dos serviços fornecidos, em vez da duração da relação ${ }^{12}$ " (p.16). Os autores concluíram que para o PAPN contratar serviços de consultoria de seu contador, precisa perceber nele um fornecedor crível desse serviço e para que a contratação ocorra, duas condições precisam ser atendidas: os serviços tradicionais precisam ser feitos com alta qualidade e a pequena empresa ambicione crescer ou se desenvolver (Gooderham et al., 2004).

Padula (1996), ao investigar a diversificação do escritório contábil, enxerga o contabilista com um assessor multidisciplinar, graças à sua prática e às observações de sucesso e fracassos de seus clientes, sendo capaz de refletir sobre os interesses da empresa, posicionar problemas, imaginar e implantar soluções. Segundo o autor "A questão fundamental é saber quem é o cliente e qual sua demanda" Atuando assim, "o contador seria o vetor ideal para o desenvolvimento das PMEs" (Padula, 1996).

Para conquistar seus clientes para o serviço de consultoria, além de executar os serviços tradicionais com qualidade, Rosa e Olinquevitch (2005) indicam que o profissional deve atuar com honestidade, responsabilidade, profissionalismo, otimismo, motivação, disciplina, inciativa e persistência, além de desenvolver a comunicabilidade, a liderança, a capacidade analítica, a criatividade, a preocupação com a imagem, a paciência, a simpatia e a sensibilidade.

Ocupar esse espaço no mercado exigirá preparo. De acordo com o programa 'Contabilizando o Sucesso' do CFC/SEBRAE, para que contador atue como consultor das MPEs é preciso treinamento e preparação diferenciados. Por isso, disponibilizou treinamentos e ferramentas com intuito de dar condições ao profissional de contabilidade de exercer atividades voltadas para a gestão empresarial e de elaborar diagnósticos organizacionais junto

\footnotetext{
${ }^{12}$ small firm's satisfaction with its accountant is actually independent of the duration of the relationship. Trust therefore seems to be more a result of the quality of the services delivered rather than the duration of the relationship (Gooderham et al., 2004, p.16)
} 
às suas empresas-clientes. O programa, hoje descontinuado, era formado por módulos que buscavam respeitar as necessidades locais e tinham como foco:

- Capacitação de profissional de contabilidade para atender a demanda de consultoria das micro e pequenas empresas.

- Auxílio na estruturação das organizações contábeis para atuação na contabilidade gerencial proativa.

- Capacitação para identificação de problemas e elaboração de planos de recomendação.

- Formação de uma rede de profissionais de contabilidade capacitados como multiplicadores.

- Permanente integração e modernização do setor contábil no atendimento a micro e pequenas empresas.

- Comprometimento do profissional de contabilidade em ações e programas sociais, incorporando a responsabilidade social na sua organização e em seus clientes.

- Aumento do ciclo de vida das micro e pequenas empresas a partir do apoio na gestão de seus negócios pelos contabilistas. (SEBRAE e CFC)

Essa necessidade de desenvolvimento e preparo também é reforçada pelo IFAC (2010):

Se os contadores objetivam ampliar seus serviços ofertados, a literatura enfatiza que terão de desenvolver multidisciplinariedade e ampliar suas bases de habilidades para além da contabilidade, da preparação de impostos, da auditoria e deixar de ser técnico de contas para serem profissionais de conhecimento. ${ }^{13}$ (IFAC, 2010, p.20)

Com é possível depreender da literatura apresentada, o contador tem vantagens frente a outros profissionais para a atuação como consultor das MPEs, afinal, já é visto pelos PAPNs como consultores potenciais. Porém, alguns desafios já são apontados nos estudos consultados. O contador precisa se preparar para oferecer apoio que vai além dos serviços tradicionalmente ofertados aos PAPNs.

\footnotetext{
${ }^{13}$ If accountants are to broaden their services on offer, the literature stresses that they will have to develop their multidisciplinary and skills base over and above bookkeeping, tax preparation and audit and move from being accounting technicians to be knowledge professions. (IFAC, 2010, p.20).
} 


\section{Metodologia}

Os aspectos pertinentes à metodologia são apresentados neste tópico, tais como abordagem ontológica, epistemológica e estratégia metodológica.

\subsection{Abordagem Metodológica}

O presente trabalho foi construído sob a ontologia relativista, subjetivista no âmbito epistemológico, em uma perspectiva construtivista e de metodologia qualitativa.

O relativismo, como uma forma de entender a natureza da realidade, se opõe ao realismo, o qual é definido por Lincoln e Guba (2006) como a presunção da existência de "uma realidade "real" além da imperfeita percepção humana desta. E mais, tal realidade pode ser aproximada somente por meio da utilização de métodos que impeçam a contaminação humana de sua percepção ou compreensão" (p.180). Por outro lado, os construtivistas se recusam a "adotar qualquer padrão permanente, invariável (ou fundacionalista) por meio do qual a realidade pode ser conhecida universalmente" (p.182). Os autores afirmam que os construtivistas "têm como seu primeiro campo de interesse exatamente o conhecimento social subjetivo e intersubjetivo e a construção ativa e a concriação [sic] desse conhecimento pelos agentes humanos, o qual é produzido pela consciência humana" (p.181).

Em consonância com a abordagem construtivista, a metodologia utilizada é qualitativa, que nas palavras de Fernandes e Maia (2001):

É utilizada em estudos que contextualizam o conhecimento, tomando o próprio processo de construção do conhecimento como uma dimensão importante a considerar. Este posicionamento suporta-se na crença de que não existe produção de conhecimento independente do sujeito conhecedor, assumindo-se que o investigador deve incorporar e assumir na sua produção científica a sua própria subjetividade. (Fernandes \& Maia, 2001, p. $50)$

Além disso, a heterogeneidade das MPEs é apontada por Marriott e Marriott (2000) e por Curran e Blackburn (2001) como uma das principais razões para a adoção de metodologias qualitativas. A complexidade dessas empresas é apontada por Curran e Blackburn (2001):

\footnotetext{
A aparente simplicidade da pequena empresa disparou uma grande quantidade de pesquisas. Pequeno não significa simples. Nem é apenas uma versão reduzida de um grande negócio. Um pequeno número de seres humanos envolvidos em um esforço comum pode criar interações sutis, muito complexas. Desvendar os significados subjacentes e padrões dessas interações pode estar longe de ser simples ${ }^{14}$. [Tradução livre] (Curran \& Blackburn, 2001, p. 5)
}

\footnotetext{
${ }^{14}$ The apparent simplicity of the small business has tripped up a lot of researches. Small does not mean simple. Neither is a small business merely a scaled-down version of a large business. A small number of human beings
} 
A estratégia metodológica empregada na pesquisa utiliza-se de técnicas da Grounded Theory, metodologia desenvolvida pelos sociólogos Barney G. Glaser e Anselm L. Strauss em 1967 na obra 'The discovery of Grounded Theory: strategies for qualitative research'. Essa obra apresentava alguma ênfase de epistemologia positivista, porém, em obras seguintes desses autores e, especialmente, na obra de Anselm L. Strauss e Juliet Corbin de 1968, afastaram-se do positivismo assumindo uma postura mais próxima do construtivismo (Fernandes \& Maia, 2001, p. 53).

A Grounded Theory é uma metodologia qualitativa, cujo método, nas palavras de Fernandes e Maia (2001):

Consiste num conjunto de procedimentos sistemáticos e rigorosos de análise de dados, organizados numa sequência que tende para uma maior complexidade e integração. ... tem como objetivo último gerar teoria que é construída com base na recolha e análise sistemática e rigorosa dos dados e na orientação dos investigadores através de um processo indutivo de produção do conhecimento. (Fernandes \& Maia, 2001, p. 54)

Embora o objetivo último do método seja gerar teoria, como indicado por Fernandes e Maia (2001) acima, tal estratégia metodológica foi usada no presente trabalho com o intuito de gerar um conjunto de proposições sustentadas na análise rigorosa dos dados e na revisão da literatura.

A escolha da metodologia deve-se ao fato de não existirem trabalhos que caracterizem a consultoria contábil às MPEs, embora haja muitos trabalhos sobre aspectos envolvidos na consultoria a MPEs e PMEs (Carey, 2015; Jarvis \& Rigby, 2012; Blackburn et al., 2010; Dyer \& Ross, 2007; Johnson et al., 2007; Gooderham et al., 2004; Bennett \& Robson, 2004; Jay \& Schaper, 2003; Bennett et al., 2001; Robson \& Bennett, 2000,1999). A coleta dos dados, a descrição dos sujeitos da pesquisa e o detalhamento da estratégia de análise dos dados são apresentados na sequência.

\subsection{Coleta de dados}

Entrevistas semiestruturadas têm sido utilizadas como estratégia de coleta de dados em pesquisas qualitativas sobre pequenos negócios, como nos trabalhos de Machado (2013); Carter, Burritt e Pisaniello (2013); Jarvis e Rigby (2012); Stone (2012, 2011b); Halabi, Barrett e Dyt (2010); Dyer e Ross (2007); Marriott e Marriott (2000); Hopper, Koga e Goto (1999). Essa tendência deve-se, na visão de Marriott e Marriott (2000), à notória falta de resposta a questionários e à heterogeneidade do setor. Outra dificuldade enfrentada por 
pesquisadores que se dedicam ao estudo de pequenos negócios é conseguir interlocutores, por isso, muitos trabalhos contam com número reduzido de entrevistados: Carter et al. (2013) entrevistaram sete indivíduos ao investigar como os agentes de desenvolvimento rural percebem a contribuição potencial da contratação e manutenção de contadores residentes nas comunidades rurais; Stone (2012) contou com 10 entrevistados para avaliar a efetividade da comunicação via "newsletters" dos escritórios com as MPEs clientes; o mesmo autor entrevistou 14 indivíduos para avaliar as comunicações dos contabilistas com empresas de pequeno porte (Stone, 2011b); Jarvis e Rigby (2012) contaram com 19 sujeitos de pesquisa quando pesquisaram sobre o oferecimento de serviços de recursos humanos por escritórios contábeis às pequenas empresas; Dyer e Ross (2007) entrevistaram 10 consultores para investigar a consultoria aos negócios de pequena monta; e o IFAC (2010), ao produzir artigo sobre o papel dos pequenos e médios escritórios de contabilidade em prover suporte às PMEs, complementou sua revisão de literatura com a entrevista de seis interlocutores de distintos países.

A determinação do tamanho da amostra em pesquisas qualitativas está associada à saturação das categorias teóricas estudadas, a qual ocorre, como afirma Charmaz (2006), "quando a coleta de dados frescos não desperta novas perspectivas teóricas, nem revela novas propriedades dessas categorias teóricas fundamentais ${ }^{15}$ " (p. 113). Tal saturação foi atingida neste trabalho com a participação de 24 interlocutores.

Vinte e três entrevistas semiestruturadas foram realizadas, gravadas com autorização dos entrevistados, que assinaram Termo de Consentimento Livre e Esclarecido, e transcritas, exceto três entrevistas, cujos áudios foram perdidos devido a problemas técnicos com o aparelho de gravação. Para esses casos, foram escritos relatos de memória, no qual a autora reproduziu o conteúdo da entrevista com base em sua memória e anotações. Os relatos foram validados com os correspondentes entrevistados. Também foi utilizado o relato de memória em que se procurou recuperar o depoimento dado pelo Professor Martinho Isnard Ribeiro de Almeida durante a banca de qualificação da autora sobre uma situação de consultoria em que o contador esteve envolvido. Desse modo, totalizam-se vinte e quatro documentos escritos, entre os quais vinte transcrições e quatro relatos de memória que formaram a base de dados da pesquisa.

\footnotetext{
${ }^{15}$ when gathering fresh data no longer sparks new theoretical insights, nor reveals new properties of these core theoretical categories (Charmaz, 2006, p. 113)
} 
Para esta pesquisa, foram ouvidos oito Proprietários Administradores de Pequenos Negócios (PAPNs) e dezesseis especialistas, selecionados por acessibilidade e intencionalmente em função do currículo e experiências de cada um deles. As entrevistas ocorreram entre 25 de outubro de 2013 e 20 de maio de 2015 e geraram mais de 15 horas de áudio gravado e 146 páginas de transcrição de entrevistas e de relatos de memória. $\mathrm{O}$ detalhamento das entrevistas é apresentado a seguir na Tabela 5: 
Tabela 5: Detalhamento das entrevistas

\begin{tabular}{|c|c|c|c|c|c|c|c|}
\hline Entrevistado & Sexo & Estado & Data & Forma & Duração & $\begin{array}{c}\text { Tipo de } \\
\text { Documento }\end{array}$ & $\begin{array}{l}\text { Quant. } \\
\text { Páginas }\end{array}$ \\
\hline $\begin{array}{c}\text { Especialista } \\
1\end{array}$ & Feminino & $\mathrm{RR}$ & $14 / 11 / 2013$ & Telefone & $00: 26: 19$ & Transcrição & 8 \\
\hline $\begin{array}{c}\text { Especialista } \\
2\end{array}$ & Masculino & SP & $22 / 12 / 2013$ & $\begin{array}{l}\text { Internet } \\
\text { (Skype) }\end{array}$ & 01:04:46 & Transcrição & 5 \\
\hline $\begin{array}{c}\text { Especialista } \\
3 \\
\end{array}$ & Masculino & SP & $19 / 11 / 2013$ & Pessoalmente & 00:32:00 & Transcrição & 5 \\
\hline $\begin{array}{c}\text { Especialista } \\
4 \\
\end{array}$ & Masculino & DF & $01 / 04 / 2014$ & Telefone & $00: 31: 37$ & Transcrição & 7 \\
\hline $\begin{array}{c}\text { Especialista } \\
5\end{array}$ & Masculino & SP & $29 / 05 / 2014$ & Pessoalmente & $01: 28: 46$ & Transcrição & 9 \\
\hline $\begin{array}{c}\text { Especialista } \\
6\end{array}$ & Masculino & SP & $20 / 05 / 2015$ & Pessoalmente & $00: 21: 14$ & Transcrição & 3 \\
\hline $\begin{array}{c}\text { Especialista } \\
7\end{array}$ & Masculino & SP & $16 / 12 / 2014$ & Pessoalmente & 02:05:29 & Transcrição & 21 \\
\hline $\begin{array}{c}\text { Especialista } \\
8\end{array}$ & Feminino & PR & 09/01/2015 & Pessoalmente & $01: 22: 15$ & Transcrição & 16 \\
\hline $\begin{array}{c}\text { Especialista } \\
9\end{array}$ & Feminino & PR & $14 / 01 / 2015$ & Pessoalmente & $\begin{array}{c}\text { Aproximadamente } \\
\text { 30min }\end{array}$ & $\begin{array}{l}\text { Relato de } \\
\text { Memória }\end{array}$ & 2 \\
\hline $\begin{array}{c}\text { Especialista } \\
10 \\
\end{array}$ & Feminino & MS & $23 / 02 / 2015$ & Hangout & $00: 42: 46$ & Transcrição & 6 \\
\hline $\begin{array}{c}\text { Especialista } \\
11 \\
\end{array}$ & Masculino & $\mathrm{RS}$ & $25 / 02 / 2015$ & Hangout & $00: 52: 34$ & Transcrição & 8 \\
\hline $\begin{array}{c}\text { Especialista } \\
12\end{array}$ & Masculino & PB & $26 / 02 / 2015$ & Hangout & 00:29:00 & Transcrição & 5 \\
\hline $\begin{array}{c}\text { Especialista } \\
13\end{array}$ & Masculino & SP & $18 / 03 / 2015$ & $\begin{array}{l}\text { Internet } \\
\text { (Skype) }\end{array}$ & $00: 28: 18$ & Transcrição & 6 \\
\hline $\begin{array}{c}\text { Especialista } \\
14 \\
\end{array}$ & Masculino & SP & $26 / 03 / 2015$ & Pessoalmente & $\begin{array}{c}\text { Aproximadamente } \\
\text { 30min }\end{array}$ & $\begin{array}{l}\text { Relato de } \\
\text { Memória }\end{array}$ & 1 \\
\hline $\begin{array}{c}\text { Especialista } \\
15 \\
\end{array}$ & Feminino & SP & $14 / 05 / 2015$ & $\begin{array}{c}\text { Internet } \\
\text { (Whatsapp) }\end{array}$ & 00:09:27 & Transcrição & 2 \\
\hline $\begin{array}{c}\text { Especialista } \\
16 \\
\end{array}$ & Masculino & SP & $26 / 11 / 2014$ & Pessoalmente & Não se aplica & $\begin{array}{l}\text { Relato de } \\
\text { Memória }\end{array}$ & 1 \\
\hline PAPN 1 & Feminino & $\mathrm{SP}$ & $25 / 10 / 2013$ & Pessoalmente & $00: 19: 24$ & Transcrição & 3 \\
\hline PAPN 2 & Feminino & SP & $01 / 11 / 2013$ & Pessoalmente & 00:27:30 & Transcrição & 6 \\
\hline PAPN 3 & Masculino & $\mathrm{SP}$ & $18 / 11 / 2013$ & Pessoalmente & $00: 23: 36$ & Transcrição & 6 \\
\hline PAPN 4 & Feminino & SP & $20 / 03 / 2015$ & Pessoalmente & $00: 25: 58$ & Transcrição & 5 \\
\hline PAPN 5 & Masculino & SP & $20 / 03 / 2015$ & Pessoalmente & $00: 16: 07$ & Transcrição & 5 \\
\hline PAPN 6 & Masculino & SP & $21 / 03 / 2015$ & Telefone & $\begin{array}{l}\text { Aproximadamente } \\
\text { 40min }\end{array}$ & $\begin{array}{l}\text { Relato de } \\
\text { Memória }\end{array}$ & 3 \\
\hline PAPN 7 & Feminino & SP & $29 / 03 / 2015$ & $\begin{array}{c}\text { Internet } \\
\text { (Hangout) }\end{array}$ & $00: 42: 51$ & Transcrição & 7 \\
\hline PAPN 8 & Feminino & SP & $05 / 05 / 2015$ & $\begin{array}{c}\text { Internet } \\
\text { (Hangout) }\end{array}$ & 00:26:03 & Transcrição & 6 \\
\hline & & & & & \multicolumn{2}{|c|}{ Total aproximado de $15 \mathrm{~h} 16 \mathrm{~min}$} & 146 \\
\hline
\end{tabular}

Fonte: Elaborado pela autora 
As entrevistas realizadas em 2013 foram utilizadas em artigo para disciplina do mestrado, quando a autora começou a desenhar o projeto de pesquisa, começando a entender o cenário da MPE, o relacionamento do PAPN com seu contador e as habilidades necessárias ao contabilista na atuação como consultor de pequenos negócios. Esse trabalho de campo permitiu que a investigação fosse se ajustando às demandas dos dados coletados e sua correspondente análise, tal como se espera ao utilizar a metodologia de Grounded Theory.

Sete PAPNs foram contatados e, após várias tentativas de agendamento, declinaram o convite de participação da pesquisa ou deixaram de retornar ligações e e-mails da pesquisadora. Duas Especialistas, proprietárias de escritórios contábeis, uma de São Paulo e outra da Bahia, embora tenham demonstrado bastante interesse em participar, declinaram o convite após alguns reagendamentos por conflitos com a agenda de obrigações acessórias do escritório.

Os entrevistados, PAPNs e Especialistas, são apresentados no próximo tópico. Procurou-se nessa apresentação incluir características e experiências que pudessem esclarecer o leitor sobre o lugar de onde cada um dos entrevistados falavam, porém, sem identificá-los.

\subsection{Apresentação dos Sujeitos da Pesquisa e do Roteiro de Entrevistas}

O grupo de PAPNs foi formado por cinco mulheres e três homens, donos de um pequeno negócio, todos prestadores de serviços. Cada sujeito apresentava diferentes níveis de experiência empresarial, estágios do negócio e motivações para empreender e serão denominados em diante como PAPN 1, PAPN 2, ..., e PAPN 8. Informações a respeito do perfil e experiência dos mesmos são apresentadas a seguir:

A PAPN 1, 34 anos, tem formação em História e empreende em vários micro negócios simultaneamente, sendo o mais antigo uma escola de dança, com cinco anos de funcionamento. Tem outros dois projetos nascentes. Atribui o início da atividade empreendedora em função de sua personalidade, "de querer construir coisas". Não tem formação em gestão, mas fez cursos on-line do SEBRAE, buscou literatura especializada e, no momento da entrevista, contava com uma consultoria de negócios.

A PAPN 2, 45 anos, é jornalista, proprietária de uma agência de notícias há 17 anos. Está em fase de reerguer seu negócio, o qual tem passado por dificuldades semelhantes àquelas enfrentados no começo do empreendimento. Em suas palavras: “... foi um começo muito duro e o pior é que está sendo tão duro quanto agora, nesse recomeço." Decidiu 
empreender quando rescindiu contrato de trabalho com um grande jornal. Sempre buscou apoio em cursos oferecidos pelo SEBRAE.

O PAPN 3, 33 anos, é engenheiro, pós-graduando em Administração e sempre atuou com consultoria e gestão de projetos. Dessa experiência, decidiu abrir seu próprio negócio. Suas motivações são: “O que a gente sabe fazer, o Brasil vai precisar muito nos próximos anos. Como a gente sabe fazer, a gente tem chance de dar certo". Empreendeu, há três anos, uma empresa que terceiriza projetos e está em pleno crescimento.

A PAPN 4, 25 anos, é formada em tecnologia e gastronomia e especializada em gestão de negócios e serviços de alimentação. Acredita que o empreendedorismo é algo intrínseco à sua geração: "Eu acho que tem a ver com a minha geração, a gente já nasce com essa visão de buscar oportunidades. " Recém empreendeu uma empresa de prestação de serviços de gestão administrativa e financeira e assessorias voltada para restaurantes.

O PAPN 5, 27 anos, é advogado, contador e mestrando em Contabilidade. Possui um escritório de advocacia há três anos, onde atua com pequenas e médias empresas principalmente com direito tributário. Sua decisão de montar o próprio escritório nasceu por divergências com sócios sobre práticas de gestão do escritório onde atuava antes.

O PAPN 6, 42 anos, é arquiteto e mestre em Administração. Acredita ter empreendido por influência familiar, sua mãe é empresária, e por querer "construir coisas" desde pequeno. Teve uma escola preparatória para exame vestibular por 10 anos. Hoje é administrador de um negócio familiar, uma rede de escolas de educação infantil com 34 anos de mercado e sete unidades (com cerca de 200 funcionários), sendo que ele é sócio de duas unidades.

A PAPN 7, 41 anos, é Comunicadora Social, especializada em rádio e televisão. Empreendeu no passado uma academia de dança que funcionou por pouco mais de um ano. Atuou por 14 anos em uma Organização Não Governamental, dos quais 10 foram na área de gestão. Decidiu transformar seu hobby em trabalho quando engravidou, pois, desejava ter mais tempo com seu bebê. Está iniciando um empreendimento, uma casa-atelier, que mantém com outras parceiras, realizando várias atividades tais como a produção e comercialização de artesanatos, doces caseiros, arranjos florais, organização de eventos e um brechó.

A PAPN 8, 34 anos, é arquiteta e desde sua formação, 12 anos atrás, tem empresa por causa do formato de contratação dos escritórios por onde passou. Decidiu, em 2011, iniciar 
um escritório de arquitetura para atuar de forma autônoma por não compartilhar com a filosofia de trabalho dos escritórios por onde passara e fora convidada para ser sócia. Hoje parou seu negócio e voltou a trabalhar em um escritório para se reestruturar financeiramente, principalmente por ter tido um bebê.

Com o intuito de incentivar a participação na pesquisa, foram oferecidas pela autora duas horas de consultoria em assuntos contábeis. Quatro PAPNs receberam tal consultoria após a concessão das entrevistas, são elas: PAPN 2, PAPN 4, PAPN 7 e PAPN 8.

Em síntese, pode-se afirmar que o grupo de PAPNs entrevistados é composto por pessoas com educação formal, todos com formação de nível superior. Empreenderam por diversas razões e, em geral, em áreas não relacionadas à sua formação acadêmica. Alguns podem ser caracterizados como empreendedores seriais. É um grupo com experiência relevante em empreender, alguns contando com fracassos e desistências ao longo do caminho.

As questões feitas ao grupo de PAPNs atenderam a um roteiro de entrevista e envolveram o histórico pessoal e do negócio, as razões para empreender, a preparação para gestão, os controles administrativos e financeiros, as dificuldades enfrentadas e a relação com o contador. Algumas questões são apresentadas a seguir:

- Você poderia se apresentar brevemente? Idade, formação atuação profissional.

- Por que e quando você decidiu ter um negócio/empreender? O que te levou a empreender?

- Como você administra e controla seu negócio? Você tem alguma rotina de controles administrativos e financeiros? Utiliza algum relatório ou controle de gestão? Quais?

- Quais são os problemas que você enfrenta ou enfrentou para tocar o negócio?

- Você buscou ou busca ajuda de algum profissional para superar esses problemas? Quem é ou seria esse profissional?

- Você tem ou teve Contador ou Contadora?

Os Especialistas entrevistados foram selecionados por acessibilidade e em função de suas experiências e atuação com as MPEs. Foram entrevistados quinze especialistas que são apresentados a seguir: 
A Especialista 1 é Professora de instituição de ensino superior pública federal no curso de Ciências Contábeis, ex-consultora do SEBRAE do estado, contadora de formação, com mestrado em Contabilidade.

O Especialista 2 foi gerente de projetos educacionais de um órgão de normatização contábil, além de ser professor, consultor e economista de formação, com doutorado em Contabilidade.

O Especialista 3 é auditor-sócio de umas das quatro principais empresas globais de auditoria, com experiência no atendimento de PME, tendo atuado por anos em escritórios contábeis.

O Especialista 4 é contador e engenheiro agrônomo por formação. Atua na área de concessão de crédito a Pequenas e Médias Empresas de um grande banco de desenvolvimento.

O Especialista 5 é administrador, atuando na área administrativa de uma Incubadora de Empresas de Base-Tecnológica do estado de São Paulo, onde oferece consultoria de assuntos administrativos e financeiros aos incubados.

O Especialista 6 é contador, professor doutor em Contabilidade em instituição de ensino superior pública. Atuou, 30 anos atrás, com pequenas empresas, ora como dono de escritório contábil, ora como diretor de uma pequena indústria, totalizando uma experiência média de 15 anos na área. Hoje seu principal interesse de pesquisa é a Contabilidade Gerencial.

O Especialista 7 é veterinário, contador e mestrando em Contabilidade. Possui um escritório contábil na cidade de São Paulo, filial do escritório de seu pai na cidade de Santos, ambos no estado de São Paulo. Seu escritório é especializado no atendimento de negócios veterinários. Iniciou um trabalho voltado à consultoria contábil, mas precisou interromper por causa do mestrado.

A Especialista 8 é contadora com pós-graduação na área. Atuou em escritórios contábeis e há cinco anos conduz o próprio escritório em Curitiba, Paraná, com uma carteira em expansão, hoje com 45 clientes, parte adquiridos do antigo dono, por arrendamento. 
A Especialista 9 é contadora, mestre e doutoranda em Contabilidade em universidade pública do estado do Paraná. Pesquisou em sua dissertação de mestrado a comunicação dos contabilistas com pequenas empresas e tem se dedicado à pesquisa na área.

A Especialista 10 é contadora, mestre e doutoranda em Contabilidade em universidade pública do Rio de Janeiro. Atualmente é professora de contabilidade em universidade pública do Mato Grosso do Sul, onde coordena projetos de extensão destinado a MPEs, além de já ter trabalhado com esse público em escritórios contábeis antes de sua entrada na universidade.

O Especialista 11 é contador e mestre em Contabilidade. Atuou em auditoria em uma das "Big Four" e há quatro anos atua no escritório contábil de sua família, que já tem 60 anos de mercado no Rio Grande do Sul e tem grande parte de sua carteira de clientes de Empresas de Pequeno Porte.

O Especialista 12 é contador, mestre e doutorando em Contabilidade em universidade pública do Rio de Janeiro. Atuou em escritório contábil voltado ao atendimento de MPEs na Paraíba, onde posteriormente constituiu um escritório próprio direcionada à consultoria contábil.

O Especialista 13 é mestre e doutor em Administração. Como professor atua no mestrado profissional de um curso especializado em Empreendedorismo em uma faculdade privada em São Paulo. Além disso, é consultor empresarial nas áreas de inovação corporativa, estratégia e planejamento de negócios.

O Especialista 14 é administrador, mestre e doutor em Administração. Atua como coordenador de projetos e como professor em faculdade privada em São Paulo, onde coordena cursos de gestão voltado a PMEs. Sua dissertação de mestrado foi um dos trabalhos pioneiros no Brasil sobre Pequenos Negócios.

A Especialista 15 é contadora, mestre e doutora em Administração. É Professora de Contabilidade em universidade pública em São Paulo. Já atuou na consultoria a PMEs, além de ter orientado trabalhos sobre esse setor.

O Especialista 16 é administrador, mestre e doutor em Administração. É professor em universidade pública em São Paulo, onde dedica-se principalmente aos seguintes temas: administração estratégica, planejamento estratégico, empreendedorismo e inovação. Já atuou na consultoria a PMEs. 
Analisando o grupo de Especialistas, pode-se afirmar que têm formações em diferentes áreas, muitos com pós-graduação e especialização, e alguns atuando como professores no ensino superior. Todos têm muitos anos de experiência profissional com MPEs, alguns com escritórios de contabilidade, outros, especificamente, em consultoria e alguns em órgãos de apoio e normatizadores. Atuam em diversos estados, mas com concentração em São Paulo.

Os Especialistas que tem ou tiveram uma pequena empresa compartilharam suas experiências também como empresários, além daquela de apoiadores da MPE.

Para os Especialistas, o guia de entrevista incluiu perguntas sobre o histórico pessoal e profissional, problemas enfrentados pelas MPEs e aspectos da relação entre o profissional apoiador de um pequeno negócio e seus respectivos proprietários. São exemplos das perguntas:

- Você poderia se apresentar brevemente? Idade, formação atuação profissional. Se Contador (a), como entrou na área? Por que a escolha?

- Qual sua experiência com MPEs? Há quanto tempo você atua, ou por quanto tempo atuou com esse tipo de empresa?

- Durante o seu contato com as MPEs, quais os principais problemas enfrentados por essas empresas e seus empresários, na sua percepção? Quais são as causas desses problemas?

- Como essas empresas podem ou poderiam superar esses problemas? Elas podem ou poderiam ser auxiliadas?

- O contador pode ou poderia ajudá-las a enfrentar e superar esses problemas? Se sim, de que maneira?

A esses roteiros básicos, tanto para PAPNs, quanto para Especialistas, perguntas adicionais eram feitas em consonância com as respostas para entendimento em profundidade da realidade específica de cada sujeito da pesquisa.

\subsection{Estratégia para Análise dos Dados}

As mais de 15 horas de áudio foram transcritas e imputadas no software QSR-Nvivo, versão 10 , utilizando-se dos benefícios oferecidos pelo programa destinado à análise de dados em pesquisas qualitativas. Uma vez os dados no sistema, iniciou-se por sua codificação. 
Codificar, como explica Charmaz (2006, p. 43), "significa categorizar segmentos de dados com um nome curto que, simultaneamente, resume e conta cada pedaço dos dados ${ }^{16}$ ". Ainda segundo a autora, os códigos mostram como os dados foram selecionados, separados e classificados pelo pesquisador antes de iniciar-se a "contabilidade analítica" dos mesmos (Charmaz, 2006).

De acordo com Saldaña (2013, p. 3), "um código em pesquisa qualitativa é, na maioria das vezes, uma palavra ou frase curta que simbolicamente atribui uma essência capturada sumarizada e saliente e/ou um atributo evocativo para uma porção de dados baseadas na linguagem ou dados visuais."

A importância do processo de codificação é sintetizada por Charmaz (2006) em:

Codificação é o elo fundamental entre a coleta de dados e desenvolvimento de uma teoria emergente para explicar esses dados. Através da codificação, você define o que está acontecendo nos dados e começa a lidar com o que isso significa ${ }^{17}$. [tradução livre] (Charmaz, 2006, p. 46)

De acordo com Emerson, Fretz e Shaw (1995), a codificação em pesquisa qualitativa ocorre, usualmente, em duas diferentes fases: codificação aberta e codificação focada. $\mathrm{Na}$ codificação aberta, o pesquisador "lê os textos linha a linha para identificar e formular alguma e todas as ideias, temas ou assuntos que eles [os textos] sugerem, não importando quão variados ou díspares sejam" as ideias. Já na codificação focada, os temas codificados na fase anterior serão "base dos tópicos que serão identificados de acordo com um interesse particular" (p.143).

Charmaz (2006), em seu guia prático "Grounded Theory Practice", divide o processo de codificação nas seguintes etapas: codificação inicial, codificação focada, codificação axial e codificação teórica. Na primeira fase, ou seja, na codificação inicial, faz-se a rotulação dos dados atendo-se estritamente às fontes. Essa codificação pode ser feita fragmentando-se os textos palavra a palavra, linha a linha ou incidente a incidente. Nas palavras da autora, essa fase:

Força você [pesquisador] a pensar sobre o material em novas formas que podem diferir das interpretações de seus participantes da pesquisa. Seu olho analítico e conhecimento sobre o assunto levam você a olhar para as declarações e ações dos participantes de maneiras que podem não ter ocorrido a eles .... Você também ganha distância de seus preconceitos e das

\footnotetext{
${ }^{16}$ [coding] means categorizing segments of data with a short name that simultaneously summarizes and accounts for each piece of data (Charmaz, 2006, p. 43).

${ }^{17}$ Coding is the pivotal link between collecting data and developing an emergent theory to explain these data. Through coding, you define what is happening in the data and begin to grapple with what it means. (Charmaz, 2006, p. 46)
} 
suposições tomadas por certo pelos participantes sobre o material, de modo que possa vê-lo em uma nova perspectiva ${ }^{18}$. [tradução livre] (Charmaz, 2006, p. 55)

A fase seguinte, codificação focada, consiste em selecionar o código, o rótulo, mais significante e/ou frequente para filtrar uma grande quantidade de dados com o objetivo de determinar a adequação dos códigos (Charmaz, 2006). A codificação axial, por sua vez, "relaciona categorias a subcategorias, especifica as propriedades e dimensões de uma categoria e remonta os dados que foram fraturados durante a codificação inicial para dar coerência à análise emergente" (Charmaz, 2006, p. 60).

Por fim, Charmaz (2006) apresenta a codificação teórica como “um nível sofisticado da codificação que segue os códigos escolhidos durante a codificação focada. .... Em suma, os códigos teóricos especificam a possível relação entre as categorias desenvolvidas na codificação anterior." (p.63). A autora também afirma que:

Os códigos teóricos são integrativos, eles emprestam forma aos códigos focados coletados. Esses códigos podem ajudá-lo a contar uma história analítica que tenha coerência. Assim, eles não só conceituam como os seus códigos substantivos estão relacionados, mas também movem a sua história analítica em uma direção teórica. [tradução livre] (Charmaz, 2006, p. 63)

O presente trabalho seguiu o formato de Charmaz (2006), cujo processo de codificação ocorre em quatro fases: inicial, focada, axial e teórica, sendo que as duas primeiras foram feitas integralmente no software Nvivo e as demais com uso de planilhas do MSExcel. Tal processo de análise foi representado na Figura 1:

\footnotetext{
${ }^{18}$ Coding forces you to think about the material in new ways that may differ from your research participants interpretations. Your analytic eye and disciplinary background lead you to look at their statements and actions in ways that may not have occurred to them.... You also gain distance from your preconceptions and your participants' taken-for-granted assumptions about the material so that you can see it in new light. (Charmaz, 2006, p. 55)
} 
Figura 1: Representação do Processo de Codificação dos Dados
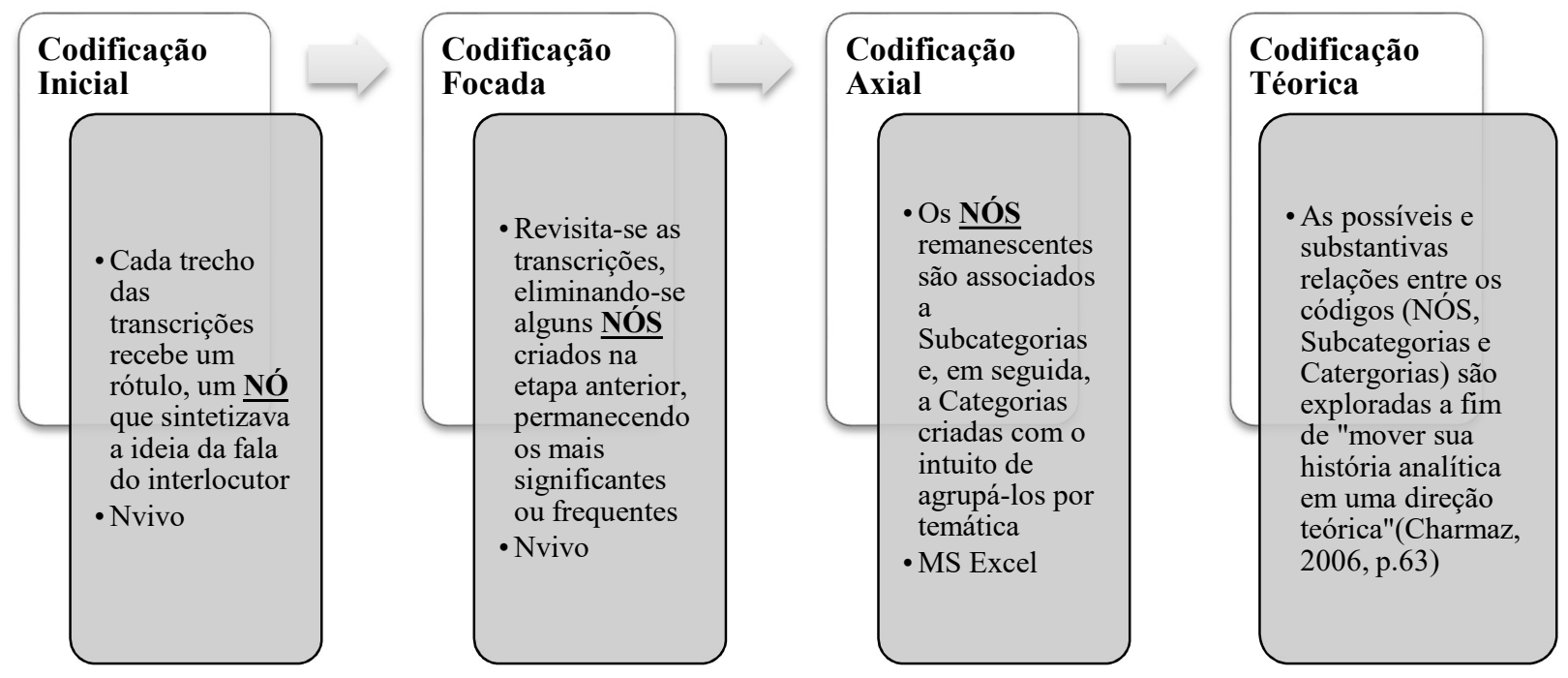

Fonte: Elaborado pela Autora para representar o processo proposto por Charmaz (2006).

A codificação inicial foi feita linha a linha. No software Nvivo, cada linha ou trecho recebeu um código, um rótulo, que no sistema é chamado de 'nó'. A Tabela 6 demonstra como a codificação inicial foi realizada em excertos da transcrição de dois Especialistas:

Tabela 6: Exemplo da Codificação Inicial

\begin{tabular}{|c|c|}
\hline Transcrição - Codificação Inicial & Nós criados na Codificação Inicial \\
\hline $\begin{array}{l}\text { Então, como a gente estava conversando, eu comecei, eu tinha atuado com } \\
\text { empresas de serviços, empresas industriais, tudo pequena empresa, bem } \\
\text { pequenininha mesmo. E a maior dificuldade que a gente encontra com esse tipo } \\
\text { de empresa é a profissionalização das pessoas. Normalmente o cara não tem } \\
\text { condição de pagar um bom profissional, uma consultoria. Ele mesmo, muitas } \\
\text { vezes, é um cara empreendedor, ele entende da profissão, ele é um engenheiro, ela } \\
\text { é uma costureira, mas não entende de gestão de empresa. Então, essa falta de } \\
\text { conhecimento, de profissionalização eu acho que é o pior problema, o principal } \\
\text { problema. Eu acho que passa por aí, essa falta também é por falta de dinheiro, } \\
\text { falta de tempo, falta de recursos para que ele possa se profissionalizar, diferente } \\
\text { de uma grande empresa que tem muita gente, que pode contratar uma consultoria. } \\
\text { Essa é que eu acho que é a dificuldade. [Especialista 15] }\end{array}$ & $\begin{array}{l}\text { Experiência com PE industriais e de serviços } \\
\text { Profissionalização das pessoas como maior dificuldade das PEs } \\
\text { PE sem dinheiro para pagar bom profissional ou consultoria } \\
\text { Empresário entende do seu ramo técnico, mas não de gestão_Profissionalização } \\
\text { Falta de recursos, dinheiro e tempo, para o empresário se profissionalizar, } \\
\text { contratar consultoria }\end{array}$ \\
\hline $\begin{array}{l}\text { [ Os contadores oferecem contabilidade gerencial aos clientes? ] Não, a gente não faz } \\
\text { a gerencial para ele, a gente faz a contabilidade para escrituração de } \\
\text { contabilidade por fora, a contabilidade societária. Esse é o nosso serviço, a gente } \\
\text { não tem condiçóes de fazer isso dentro da empresa, a gente até tem alguns clientes } \\
\text { que a gente busca oferecer isso, mas a consultoria, a gente até presta consultoria } \\
\text { para esse fim, só que nós não temos condições de fazer a contabilidade gerencial, } \\
\text { isso sendo um contador terceirizado eu percebo que não é muito difícil de fazer, } \\
\text { teria de ter uma pessoa interna lá e o mais indicado seria o próprio gestor, porque } \\
e \text {, muitas vezes, o proprietário do negócio, seria a pessoa mais indicada para } \\
\text { fazer esse controle, essa contabilidade gerencial. [Especialista 11] }\end{array}$ & $\begin{array}{l}\text { Escritório não oferece contabilidade gerencial, faz apenas a societária } \\
\text { Escritório oferece contabilidade gerencial como produto da consultoria } \\
\text { Dificuldade para o contador terceirizado fazer contabilidade gerencial, o ideal } \\
\text { seria que o próprio gestor a fizesse }\end{array}$ \\
\hline
\end{tabular}

Fonte: Elaborado pela Autora

As cores da Tabela 6 acima indicam o trecho da transcrição do lado direito associado ao nó do lado esquerdo.

Nessa etapa, 1.378 nós foram gerados. São exemplos desses nós: 
> Adequar nomenclatura de contas contábeis para facilitar entendimento do cliente

$>$ Contabilidade deve ser olhada de maneira prospectiva e não retrospectiva

$>$ A maioria dos clientes só procura suporte quando tem problema

$>$ Aconselhamento para ter um subproduto vendável enquanto desenvolve seu produto principal

Apoiando na decisão de vendas por margem de lucro x volume x poder de barganha

$>$ Captando o problema com o cliente

$>$ Consultor com liberdade para dar respostas mais evasivas, 'veja bem'

$>$ Informações gráficas

O contador do escritório não priorizou ter visão de consultor

$>$ Preparar-se para as diligências contábeis do investidor

$>$ Aprender com os erros

$>$ A busca pela sobrevivência como dificultador para implantar ferramentas de gestão

$>$ Não consegue subir seu preço porque seus concorrentes cobram pouco

$>\mathrm{PE}$ anã, com deformidades e que nunca irá crescer

$>$ Importância da formalização para a divulgação do negócio

$>$ Impacto do apoio à PE na geração de empregos

$>$ Antecipou o lançamento de sua empresa por causa de uma oportunidade

$>$ Dificuldade em se adequar ao novo cenário mercadológico e às novas demandas

> Seleção natural do mercado, algumas empresas vão morrer

$>$ Se sair do SIMPLES, a sobrevivência do negócio fica comprometida

A lista completa dos 1.378 nós criados é apresentada no Apêndice 2. Cada nó está associado à fala de um único entrevistado, exceto dois nós: 'Definição de ME' e 'Experiência com MPME em escritórios de contabilidade', que receberam trechos de dois entrevistados, cada um.

Na segunda etapa, a codificação focada, foram selecionados os nós que, dentre aqueles criados na etapa anterior, melhor sintetizavam as experiências compartilhadas em cada trecho das falas dos interlocutores, de maneira tal que 662 nós foram eliminados, permanecendo 716 nós. Tal procedimento é demonstrado utilizando-se os mesmos excertos apresentados na Tabela 6 anteriormente na Tabela 7: 
Tabela 7: Exemplo Comparativo das Codificações Inicial e Focada

\begin{tabular}{|c|c|}
\hline Transcrição - Codificação Inicial & ados na Codificação Inicial (5 nós) \\
\hline 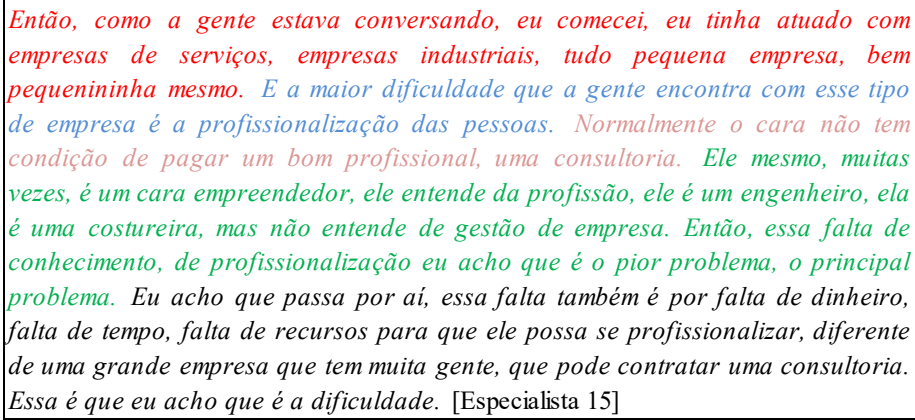 & $\begin{array}{l}\text { Experiência com PE industriais e de serviços } \\
\text { Profissionalização das pessoas como maior dificuldade das PEs } \\
\text { PE sem dinheiro para pagar bom profissional ou consultoria } \\
\text { Empresário entende do seu ramo técnico, mas não de gestão_Profissionalização } \\
\text { Falta de recursos, dinheiro e tempo, para o empresário se profissionalizar, } \\
\text { contratar consultoria }\end{array}$ \\
\hline Transcrição - Codificação Focada & Nós que permaneceram na Codificação Focada (4 nós remane \\
\hline 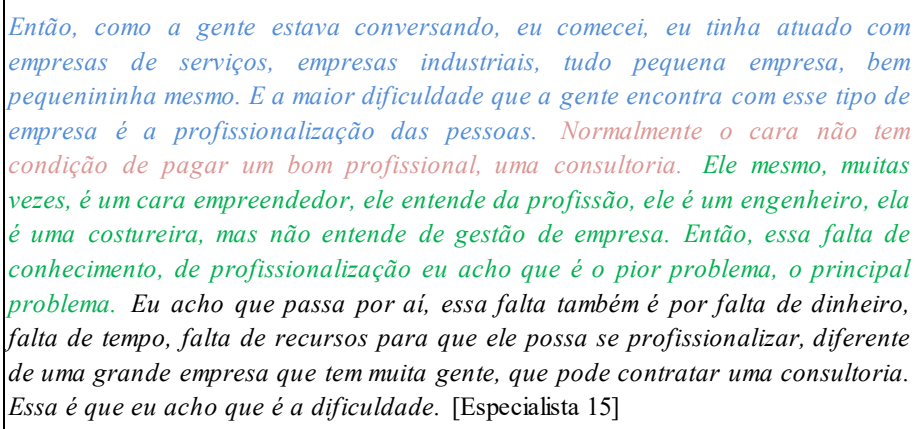 & $\begin{array}{l}\text { Experiêneia com PE industriais e de serviços ELIMINADO } \\
\text { Profiss ionalização das pess oas como maior dificuldade das PEs } \\
\text { PE sem dinheiro para pagar bom profissional ou consultoria } \\
\text { Empresário entende do seu ramo técnico, mas não de gestão_Profissionalização } \\
\text { Falta de recursos, dinheiro e tempo, para o empresário se profissionalizar, } \\
\text { contratar consultoria }\end{array}$ \\
\hline Transcrição - Codificação Inicial & Nós c \\
\hline $\begin{array}{l}\text { [ Os contadores oferecem contabilidade gerencial aos clientes? ] Não, a gente não faz } \\
\text { a gerencial para ele, a gente faz a contabilidade para escrituração de } \\
\text { contabilidade por fora, a contabilidade societária. Esse é o nosso serviço, a gente } \\
\text { não tem condições de fazer isso dentro da empresa, a gente até tem alguns clientes } \\
\text { que a gente busca oferecer isso, mas a consultoria, a gente até presta consultoria } \\
\text { para esse fim, só que nós não temos condições de fazer a contabilidade gerencial, } \\
\text { isso sendo um contador terceirizado eu percebo que não é muito difícil de fazer, } \\
\text { teria de ter uma pessoa interna lá e o mais indicado seria o próprio gestor, porque } \\
\text { é, muitas vezes, o proprietário do negócio, seria a pessoa mais indicada para } \\
\text { fazer esse controle, essa contabilidade gerencial. [Especialista 11] }\end{array}$ & $\begin{array}{l}\text { Escritório não oferece contabilidade gerencial, faz apenas a societária } \\
\text { Escritório oferece contabilidade gerencial como produto da consultoria } \\
\text { Dificuldade para o contador terceirizado fazer contabilidade gerencial, o idea } \\
\text { seria que o próprio gestor a fizesse }\end{array}$ \\
\hline Transcrição - Codificação Focada & ermaneceram na Codificação Focada (1 nó remanes cente) \\
\hline $\begin{array}{l}\text { [ Os contadores oferecem contabilidade gerencial aos clientes? ] Não, a gente não faz } \\
\text { a gerencial para ele, a gente faz a contabilidade para escrituração de } \\
\text { contabilidade por fora, a contabilidade societária. Esse é o nosso serviço, a gente } \\
\text { não tem condições de fazer isso dentro da empresa, a gente até tem alguns clientes } \\
\text { que a gente busca oferecer isso, mas a consultoria, a gente até presta consultoria } \\
\text { para esse fim, só que nós não temos condições de fazer a contabilidade gerencial, } \\
\text { isso sendo um contador terceirizado eu percebo que não é muito difícil de fazer, } \\
\text { teria de ter uma pessoa interna lá e o mais indicado seria o próprio gestor, porque } \\
e ́, \text { muitas vezes, o proprietário do negócio, seria a pessoa mais indicada para }\end{array}$ & 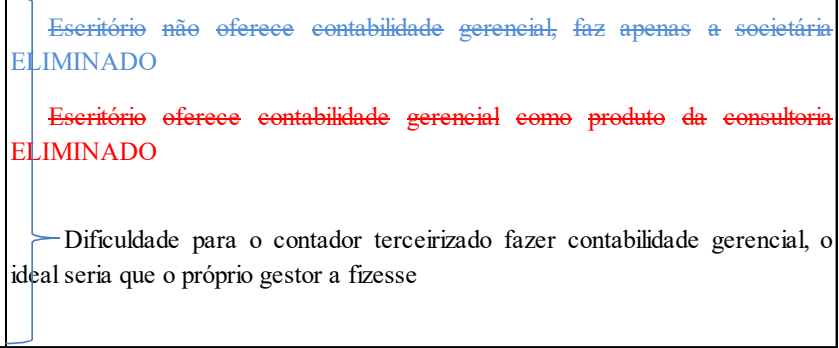 \\
\hline
\end{tabular}

Fonte: Elaborado pela Autora

Após o término da codificação focada, foi gerada uma listagem no Nvivo com todos

os nós remanescentes e transferida para o MSExcel, software no qual se procedeu o

grupamento desses nós de acordo com a proximidade temática de cada um, iniciando-se, assim, a codificação axial. Nessa etapa, os dados fragmentados nas fases anteriores são novamente reunidos, porém organizados de maneira que tragam "coerência à análise emergente", tal como afirma Charmaz (2006, p.60). O grupamento dos 716 nós originou 59 subcategorias, as quais são demonstradas na Tabela 8 a seguir: 
Tabela 8: Subcategorias criadas na Codificação Axial

\begin{tabular}{|c|c|c|c|}
\hline Subcategorias & $\begin{array}{c}\text { Quant. } \\
\text { Nós } \\
\text { associados } \\
\end{array}$ & Subcategorias & $\begin{array}{c}\text { Quant. } \\
\text { Nós } \\
\text { associados }\end{array}$ \\
\hline Acessibilidade econômica à consultoria & 5 & Formalização & 5 \\
\hline $\begin{array}{l}\text { Acompanhamento, contato constante, criação } \\
\text { de canais e proativo }\end{array}$ & 5 & $\begin{array}{l}\text { Gestão/Administração do Negócio pelo } \\
\text { PAPN }\end{array}$ & 87 \\
\hline $\begin{array}{l}\text { Aconselhamento de negócios, estratégia, } \\
\text { planejamento e mercado }\end{array}$ & 11 & Honorários do Contador & 25 \\
\hline Adequação de relatório & 9 & Impacto econômico da MPE & 3 \\
\hline Ambiente desfavorável à MPE & 12 & $\begin{array}{l}\text { Informatização do governo X Risco para } \\
\text { Despachante }\end{array}$ & 2 \\
\hline Análises financeiras & 6 & Informatização do governo X Sonegação & 6 \\
\hline Aprendendo com erros & 3 & $\begin{array}{l}\text { Linguagem acessível, tradução de termos e } \\
\text { ajustes de linguagem }\end{array}$ & 12 \\
\hline Carga Tributária e Sonegação & 20 & Mortalidade e Sobrevivência da MPE & 6 \\
\hline Complexidade das normas e burocracia & 9 & $\begin{array}{l}\text { Mudanças de cenários de mercado } \\
\text { (Dificuldades e Oportunidades) }\end{array}$ & 8 \\
\hline Confusão entre PJ e PF & 5 & Multidisciplinariedade na atuação & 3 \\
\hline Conhecimento de mercado, setor, negócio & 13 & Orientação em administração e gestão & 14 \\
\hline Contabilidade Gerencial & 6 & $\begin{array}{l}\text { Orientação na busca por capital, } \\
\text { investimentos e financiamentos }\end{array}$ & 4 \\
\hline Contabilidade oficial feita para o fisco & 6 & $\begin{array}{l}\text { Orientação para soluções, seus riscos e } \\
\text { impactos }\end{array}$ & 10 \\
\hline $\begin{array}{l}\text { Contabilidade Societária feita por } \\
\text { obrigatoriedade }\end{array}$ & 5 & Papel da Universidade & 9 \\
\hline Conversão para padrão internacional IFRS & 4 & $\begin{array}{l}\text { PAPN: desconhecimento sobre função do } \\
\text { Contador }\end{array}$ & 6 \\
\hline $\begin{array}{l}\text { Credores avaliam o crédito com base na c/c, } \\
\text { como PF }\end{array}$ & 4 & PAPN: Perfil e Personalidade & 36 \\
\hline Definição de MPE & 5 & Planejamento tributário & 4 \\
\hline $\begin{array}{l}\text { Desenvolvimento de Plano de Negócios e } \\
\text { orçamentos, visão longo prazo }\end{array}$ & 25 & Pouca exposição ao usuário externo & 2 \\
\hline Desinteresse do Contador na MPE & 2 & Razões para empreender & 7 \\
\hline Despachante de Impostos e Folha & 41 & Redes de relacionamento & 3 \\
\hline Diagnóstico & 3 & Regime tributário simplificado & 22 \\
\hline Dificuldades enfrentadas pela MPE & 47 & Regularidade em vários âmbitos & 2 \\
\hline Dinâmica do Escritório Contábil & 75 & Relação de Confiança & 15 \\
\hline $\begin{array}{l}\text { Disponibilidade, abertura ao diálogo e 'saber } \\
\text { quem procurar' }\end{array}$ & 3 & Relacionamento Contador - PAPN & 9 \\
\hline Empatia & 8 & Responsabilidade Civil & 2 \\
\hline Ética & 5 & Satisfação pessoal & 6 \\
\hline $\begin{array}{l}\text { Fatores associados à busca por apoio, } \\
\text { aconselhamento, consultoria }\end{array}$ & 19 & Solidão do PAPN na condução do negócio & 5 \\
\hline Flexibilidade e proximidade & 4 & Treinamento para PAPN & 18 \\
\hline \multirow{2}{*}{ Formação do Contador } & \multirow{2}{*}{19} & $\begin{array}{l}\text { Usuário está dentro da empresa, utiliza } \\
\text { relatórios próprios }\end{array}$ & 3 \\
\hline & & $\begin{array}{l}\text { Valorizar, aproveitar os controles e } \\
\text { conhecimento do PAPN }\end{array}$ & 3 \\
\hline Total de Nós & 379 & Total de Nós & 337 \\
\hline & \multicolumn{2}{|r|}{ Total Geral de Nós $(379+337)$} & 716 \\
\hline
\end{tabular}

Fonte: Elaborado pela Autora 
Após a criação das subcategorias acima apresentadas, buscou-se refletir de que maneira essas subcategorias se relacionavam com o código axial, ou seja, o eixo principal da pesquisa, a consultoria contábil, e com base nos dados e na literatura previamente consultada, sete categorias foram criadas: PAPN, Contexto da MPE, Escritório Contábil, Contabilidade Societária, Ensino de Contabilidade, Tributos e Burocracia, Comunicação e Consultoria. O relacionamento e a quantidade de nós associados a cada categoria são representados na Figura 2:

Figura 2: Diagrama da relação entre as Categorias

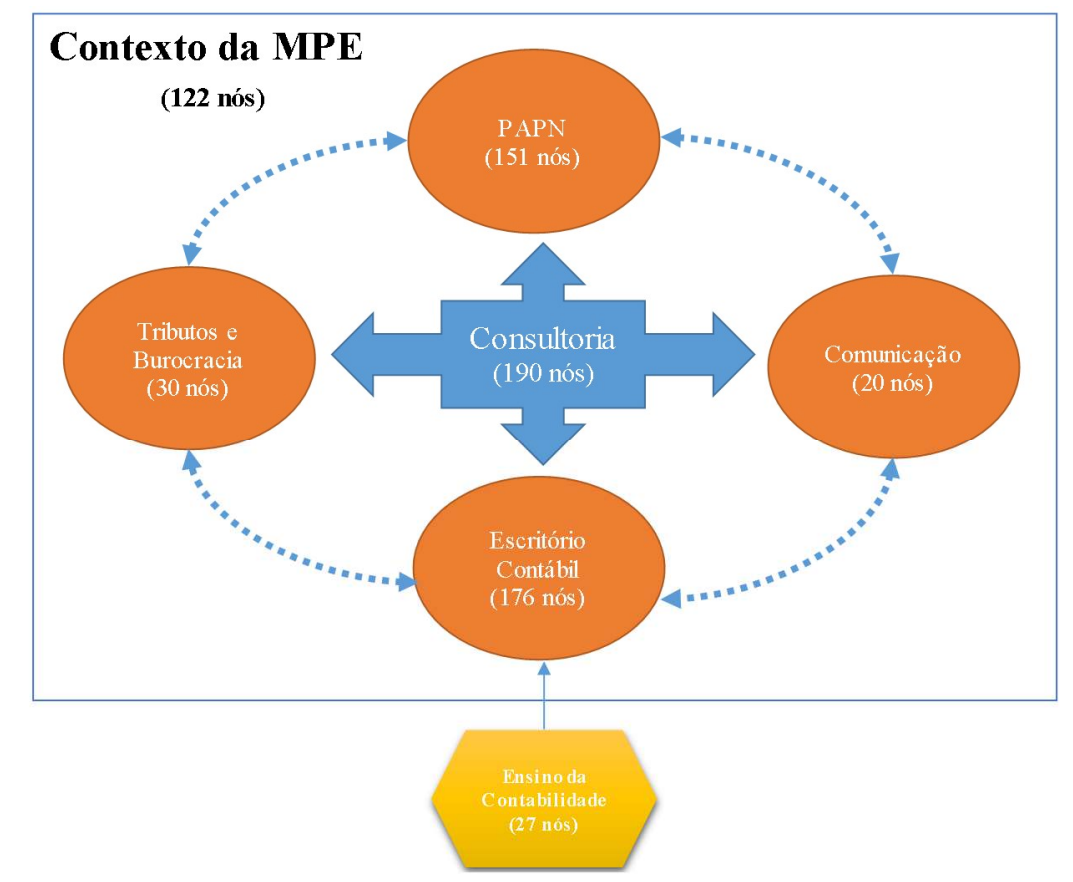

Fonte: Elaborada pela Autora

A organização dos dados, trechos das transcrições associados a um nó, uma subcategoria e a uma categoria, permitiu codificação teórica, a qual é conduzida na seção de análise e discussão dos dados, etapa em que também foi considerada a recorrência dos temas entre os interlocutores, Especialistas e PAPNs, enfatizando-se aqueles mencionados pelo maior número de sujeitos. A distribuição da quantidade de nós atribuídos a cada subcategoria por interlocutor é apresentada na Tabela 9: 
Tabela 9: Distribuição da quantidade de nós por Categorias e Entrevistados

\begin{tabular}{|c|c|c|c|c|c|c|c|c|c|c|c|c|c|c|c|c|c|c|c|c|c|c|c|c|c|}
\hline Categorias & $\begin{array}{l}\mathbf{E} \\
\mathbf{1}\end{array}$ & $\begin{array}{l}\mathbf{E} \\
2\end{array}$ & $\begin{array}{l}\mathbf{E} \\
\mathbf{3}\end{array}$ & $\begin{array}{l}E \\
4\end{array}$ & $\begin{array}{l}\mathbf{E} \\
\mathbf{5}\end{array}$ & $\begin{array}{l}E \\
6\end{array}$ & $\begin{array}{l}E \\
7\end{array}$ & $\begin{array}{l}E \\
8\end{array}$ & $\begin{array}{l}\text { E } \\
9\end{array}$ & $\begin{array}{c}\mathbf{E} \\
\mathbf{1 0}\end{array}$ & $\begin{array}{c}E \\
11\end{array}$ & $\begin{array}{c}E \\
12\end{array}$ & $\begin{array}{c}\mathbf{E} \\
13\end{array}$ & $\begin{array}{l}E \\
14\end{array}$ & $\begin{array}{c}\mathbf{E} \\
15\end{array}$ & $\begin{array}{c}E \\
16\end{array}$ & $\begin{array}{l}\mathbf{P} \\
1\end{array}$ & $\begin{array}{l}\mathbf{P} \\
\mathbf{2}\end{array}$ & $\begin{array}{l}\mathbf{P} \\
\mathbf{3}\end{array}$ & $\begin{array}{l}P \\
4\end{array}$ & $\begin{array}{l}\mathbf{P} \\
\mathbf{5}\end{array}$ & $\begin{array}{l}P \\
6\end{array}$ & $\begin{array}{l}\mathbf{P} \\
7\end{array}$ & $\begin{array}{l}\mathbf{P} \\
8\end{array}$ & $\Sigma$ \\
\hline PAPN & 1 & & 2 & 2 & 4 & 7 & 7 & 18 & 2 & 16 & 3 & 6 & 12 & 1 & 2 & & 6 & 10 & 4 & 10 & 3 & 4 & 15 & 16 & 151 \\
\hline Contexto MPE & 3 & 4 & 2 & 12 & 8 & 5 & 8 & 16 & & 7 & 1 & 2 & 6 & 1 & 1 & & 1 & 7 & & 6 & 1 & 3 & 14 & 14 & 122 \\
\hline Escritório & 5 & 1 & 7 & 3 & 8 & 4 & 45 & 32 & 2 & 4 & 9 & 4 & 7 & 1 & 4 & & 6 & 3 & 10 & 7 & 5 & 2 & & 7 & 176 \\
\hline $\begin{array}{l}\text { Ensino da } \\
\text { Contabilidade }\end{array}$ & 3 & & 3 & & & & 5 & 1 & & 7 & 1 & & 1 & & & & & & & 1 & 5 & & & & 27 \\
\hline $\begin{array}{l}\text { Tributos e } \\
\text { Burocracia }\end{array}$ & & & 3 & & & 3 & 7 & 6 & & 2 & 4 & & & & & & & & & & & 1 & & 4 & 30 \\
\hline Comunicação & 6 & & & 3 & 1 & & 3 & & 1 & & 2 & 1 & & & & & 1 & & 2 & & & & & & 20 \\
\hline Consultoria & 4 & 3 & 6 & 14 & 26 & 3 & 29 & 19 & 1 & 7 & 8 & 11 & 10 & 1 & 6 & 1 & 1 & 9 & 4 & 10 & 6 & 2 & 4 & 5 & 190 \\
\hline$\sum$ & 22 & 8 & 23 & 34 & 47 & 22 & 104 & 92 & 6 & 43 & 28 & 24 & 36 & 4 & 13 & 1 & 15 & 29 & 20 & 34 & 20 & 12 & 33 & 46 & 716 \\
\hline
\end{tabular}

Fonte: Elaborado pela Autora $(\mathrm{E}=$ Especialista e $\mathrm{P}=\mathrm{PAPN})$

A distribuição do número de nós por subcategorias e entrevistados é apresentada no Apêndice 2.

Em resumo, metodologia seguida na presente pesquisa utilizou-se de técnicas de codificação da Grounded Theory apresentada por Charmaz (2006). A transcrição das mais de 15 horas de entrevistas foi codificada inicialmente linha a linha ou trecho a trecho com a geração de 1.378 nós. Na sequência, as transcrições codificadas foram revisitadas, resultandose na eliminação de 662 nós, permanecendo 716 nós que melhor sintetizavam as ideias dos interlocutores, etapa chamada de codificação focada. Esses 716 nós foram organizados e associados a 59 subcategorias, criadas de acordo com a recorrência dos temas explicitados em cada nó. Em continuidade à codificação axial, sete categorias foram criadas com o objetivo de evidenciar a relação dos nós e subcategorias com o eixo principal: a consultoria contábil.

A seção seguinte apresenta a análise e discussão dos dados, a qual foi feita principalmente com base nos relatos dos sujeitos da pesquisa, porém, a literatura consultada previamente também é retomada com o intuito de ressaltar os achados trazidos pelos dados. 


\section{Análise e Discussão dos Dados}

O resultado da codificação axial permitiu a análise mais profunda dos dados, com o objetivo de entender as relações entre as sete categorias criadas, tendo como eixo principal a consultoria contábil, tal como ilustrado na Figura 1 anteriormente apresentada. A etapa da codificação teórica é conduzida aqui por meio da análise e discussão de cada categoria criada buscando captar de forma coerente as intersecções dessas categorias com a consultoria contábil, a fim de propor um conjunto de características desse serviço a ser oferecido às MPEs e aos PAPNs, objetivo da pesquisa.

\subsection{Aspectos associados aos Proprietários Administrados de Pequenos Negócios (PAPNs)}

Foram mantidos 151 nós durante a codificação axial associados aos Proprietários Administradores de Pequenos Negócios. A maioria das falas sintetizadas nesses códigos estavam relacionadas a aspectos sobre como esses empresários conduziam e administravam seus negócios, bem como o impacto de sua personalidade ou perfil empreendedor na administração. A Tabela 10 a seguir demonstra o resumo dessa codificação:

Tabela 10: Subcategorias e nós associados aos PAPNs

\begin{tabular}{|c|c|c|c|c|c|c|c|c|c|c|c|c|c|c|c|c|c|c|c|c|c|c|c|c|c|}
\hline Categoria e Subcategoria & $\begin{array}{l}\mathbf{E} \\
\mathbf{1}\end{array}$ & $\begin{array}{l}\mathbf{E} \\
\mathbf{2}\end{array}$ & $\begin{array}{l}\mathbf{E} \\
\mathbf{3}\end{array}$ & $\begin{array}{l}\mathbf{E} \\
4\end{array}$ & $\begin{array}{l}\mathbf{E} \\
\mathbf{5}\end{array}$ & $\begin{array}{l}E \\
6\end{array}$ & $\begin{array}{l}\mathbf{E} \\
7\end{array}$ & $\begin{array}{l}\mathbf{E} \\
8\end{array}$ & $\begin{array}{l}\mathbf{E} \\
\mathbf{9}\end{array}$ & $\begin{array}{c}\mathbf{E} \\
10\end{array}$ & $\begin{array}{c}\mathbf{E} \\
11\end{array}$ & $\begin{array}{c}E \\
12\end{array}$ & $\begin{array}{c}E \\
13\end{array}$ & $\begin{array}{c}E \\
14\end{array}$ & $\begin{array}{c}E \\
15\end{array}$ & $\begin{array}{c}E \\
16\end{array}$ & $\begin{array}{l}\mathbf{P} \\
\mathbf{1}\end{array}$ & $\begin{array}{l}\mathbf{P} \\
2\end{array}$ & $\begin{array}{l}\mathbf{P} \\
\mathbf{3}\end{array}$ & $\begin{array}{l}\mathbf{P} \\
4\end{array}$ & $\begin{array}{l}\mathbf{P} \\
\mathbf{5}\end{array}$ & $\begin{array}{l}\mathbf{P} \\
6\end{array}$ & $\begin{array}{l}\mathbf{P} \\
7\end{array}$ & $\begin{array}{l}\mathbf{P} \\
8\end{array}$ & $\sum$ \\
\hline PAPN & 1 & & 2 & 2 & 4 & 7 & 7 & 18 & 2 & 16 & 3 & 6 & 12 & 1 & 2 & & 6 & 10 & 4 & 10 & 3 & 4 & 15 & 16 & 151 \\
\hline $\begin{array}{l}\text { Gestão/Administração do } \\
\text { Negócio pelo PAPN }\end{array}$ & & & & 2 & 4 & 6 & 5 & 7 & & 10 & 2 & 4 & 5 & & 2 & & 2 & 7 & 3 & 5 & 1 & 2 & 8 & 11 & 86 \\
\hline PAPN: Perfil e Personalidade & 1 & & 1 & & & 1 & 1 & 10 & 1 & 4 & & 2 & 4 & 1 & & & 1 & & 1 & 4 & 2 & & 1 & 1 & 36 \\
\hline Razões para empreender & & & & & & & 1 & 1 & & & 1 & & & & & & & 1 & & 1 & & 1 & 1 & & 7 \\
\hline $\begin{array}{l}\text { PAPN: desconhecimento } \\
\text { sobre função do Contador }\end{array}$ & & & & & & & & & 1 & & & & & & & & 3 & & & & & & & 2 & 6 \\
\hline Satisfação pessoal & & & & & & & & & & & & & & & & & & 1 & & & & & 4 & & 5 \\
\hline $\begin{array}{l}\text { Solidão do PAPN na } \\
\text { condução do negócio }\end{array}$ & & & 1 & & & & & & & & & & & & & & & 1 & & & & 1 & & 2 & 5 \\
\hline Aprendendo com erros & & & & & & & & & & 1 & & & 2 & & & & & & & & & & & & 3 \\
\hline $\begin{array}{l}\text { Desenvolvimento de Plano de } \\
\text { Negócios e orçamentos, visão } \\
\text { longo prazo }\end{array}$ & & & & & & & & & & 1 & & & & & & & & & & & & & 1 & & 2 \\
\hline Redes de relacionamento & & & & & & & & & & & & & 1 & & & & & & & & & & & & 1 \\
\hline
\end{tabular}

Fonte: Elaborado pela Autora $(\mathrm{E}=$ Especialista e $\mathrm{P}=\mathrm{PAPN})$

Os PAPNs entrevistados apresentavam distintas razões para empreender, perfil empreendedor, formação e formas de 'tocar' seus negócios. O Especialista 14 destacou que nas empresas de pequeno porte, a personalidade do gestor define, em muitos casos, a própria personalidade da empresa. É ele quem molda, com base em sua forma de lidar e ver o mundo, o perfil de funcionamento e gestão do negócio. Essa afirmação é encontrada também na fala da Especialista 8: 
Eu gostaria de falar, sim, de perfis de administradores, ou de empregadores, ou de empresários, porque a empresa nada mais é do que o reflexo do administrador. (Especialista 8)

O Especialista 6 chama a atenção para o fato de ser comum pequenos negócios familiares com a empresa personalizada na figura do fundador. O PAPN5 atrela esse ponto à resistência do membro familiar mais antigo em fazer planejamento:

Quando você pega uma empresa familiar que cresceu durante os anos, que ainda está ali muito focado na pessoa física do sócio, aquele cara que fundou a empresa lá atrás ou recebeu do lucro. Esse cara dificilmente está topando esse tipo, ou fazendo esse tipo de planejamento. (PAPN 5)

As razões para empreender são variadas. Alguns PAPNs traziam em seus discursos uma postura mais empreendedora e se reconheciam assim. É o caso do PAPN6, quem relatou ter vontade de construir coisas desde criança e, por isso, decidiu ter um negócio; do PAPN3, quem enxergou uma oportunidade de mercado dentro do seu campo de expertise e empreendeu; e da PAPN 4, quem, aos 25 anos, atribui à sua geração uma vocação nata ao empreendedorismo:

Eu acho que tem a ver com a minha geração, a gente já nasce com essa visão de buscar oportunidades, de buscar demanda que ainda não foi criada. ... São poucas as pessoas que eu vejo na minha faixa etária que não têm vontade [de empreender], que preferem trabalhar para uma empresa a vida inteira. (PAPN 4)

A satisfação pessoal é algo considerado relevante, além dos ganhos financeiros, como nota-se na fala da PAPN 7 que afirma: "isso é para mim um aprendizado maior de todos, não é só ganhar dinheiro, é fazer o que você gosta, é estar junto de gente que está na mesma história que você”. Essa empresária também viu no negócio a possibilidade de transformar seu hobby em trabalho e, assim, conseguir mais tempo para se dedicar aos filhos, em especial, seu bebê.

Outros encontraram na abertura do próprio negócio uma alternativa às barreiras para atuação como funcionários de empresas, como a PAPN 2, a qual teve dificuldades de voltar ao mercado por causa da idade e a PAPN 8, quem não se sentia confortável para se tornar sócia dos escritórios onde atingia cargos de liderança por não compartilhar da filosofia de trabalho. 
Os Contadores, donos de escritórios de contabilidade de pequeno porte aqui classificados como Especialistas, foram consultados sobre suas motivações para manterem o próprio escritório. A vontade intrínseca de empreender foi o caso da Especialista 8, enquanto para o Especialista 7 pesou primeiramente o aspecto econômico da carreira de empresário contábil comparada à sua outra formação em veterinária. Além disso, esse Especialista, assim como o Especialista 11, prosseguiu com o negócio familiar.

O perfil empreendedor foi apontado como fator de diferença para o modo de se relacionar com o negócio, lidar com a gestão e com informação contábil. Para o Especialista 13, "o cara querer ter um negócio próprio não significa necessariamente que ele tem perfil para conduzir um negócio próprio". Ainda de acordo com o entrevistado, o empreendedor assume riscos e responsabilidades, lidera pessoas e se comunica. O Especialista 7 alerta seus clientes que empreender é resolver problemas:

E a tendência é que esse cara vai saindo do operacional e só resolve problemas. Então, [e] se resolver problemas te frustra? Se psicologicamente você não encara bem, não vai aguentar? Você vai fechar. (Especialista 7)

Para a Especialista 8, o empresário com perfil empreendedor tem o hábito de buscar informação e conhecimento, tem iniciativa, prevê mudanças de mercado e então planeja-se, ajusta-se. Essa visão foi evidenciada na fala da jovem PAPN 4 quem atribuiu seu caráter empreendedor à sua geração e na fala do PAPN 3, que iniciou seu negócio ao perceber a oportunidade de mercado:

Eu pesquisei muito na internet, eu usei vários sites de contabilidade, o site do portal do empreendedor, que tem muita informação para ter certeza de tudo que é necessário, o que eu vou ter de pagar de verdade, quais vão ser os meus gastos para tomar a decisão mesmo da abertura da empresa. (PAPN 4)

Mas eu tenho o pé bem no chão para poder acompanhar o crescimento dela. Eu só vou sair do meu emprego atual quando eu tiver um fluxo de caixa para poder me sustentar e investir e me dedicar melhor. (PAPN 4)

Quando você passa a ser dono e você vê a carga tributária, uma coisa é você ser microempresa tal e tal, aí você abre uma empresa Ltda., regulada por conselho, tal e tal, tem um monte de encargos, você começa a ficar horrorizado. E eu, como 
empresário, sempre me incomodo. E eu sempre falei: "Meu, a gente tem que buscar uma iniciativa, fazer uma otimização desses impostos". (PAPN 3)

O Especialista 3 critica a falta de preparo para iniciar um empreendimento: "Antes de empreender, você tem que saber o que é que está empreendendo. Empreender por empreender é um cassino, é jogar e eu acho que isso não é empreendedorismo. " Existem aqueles empresários que não possuem perfil empreendedor. Para a Especialista 8, esses PAPNs contentam-se com um patamar de ganhos, geralmente não se preocupam com o longo prazo, concentram-se exclusivamente no fluxo de caixa de curto prazo e postergam ou ignoram problemas como riscos trabalhistas, por exemplo. A Especialista 8 resume esse tipo de empresário como o "cara que vai dançando conforme a música". O Especialista 12 relatou uma situação que evidencia o impacto da diferença de perfil empreendedor na maneira de lidar com o negócio:

Eu acho que seria até ilusão você achar que todo empresário tem a ambição de que a empresa dele cresça. Muitas vezes não. Eu já vi, eu já preveni bem antes, tem empresário que não: "O porte do meu negócio está bom, para mim é confortável". Tem uma frase de um cliente que eu acho muito interessante. Na verdade, eram dois sócios e um deles falava, um dos sócios ele sempre queria fazer mais, trabalhar mais, comprar mais máquinas e fazer projetos de financiamento e investimento, e quando a gente recebia a visita do outro sócio, o que ele dizia? "Eu não quero mais trabalho, do jeito que está, está bom para mim, eu quero viver bem, eu quero tomar minha cerveja no final de semana e não perder meu Faustão! ” (Especialista 12)

De acordo com o Especialista 13, desenvolver o lado empreendedor é essencial para o empresário que quer ir além de sobreviver:

Se o dono do negócio não tiver esse perfil empreendedor e não tiver a capacidade de aprender e desenvolver esse perfil, ele dificilmente vai conseguir fazer o negócio dele prosperar e evoluir. Pode até sobreviver, mas não vai conseguir fazer o negócio se tornar uma coisa relevante, de impacto. (Especialista 13)

A Especialista 8 aponta que há empresários que querem atuar apenas no operacional e acabam negligenciando a gestão. A preocupação com a administração, estratégia e futuro do negócio depende do que a Especialista 10 chama de 'maturidade da gestão', a qual pode ser tanto da empresa quanto do gestor e independe da idade: 
A maturidade empresarial a gente pode olhar de duas formas, a maturidade do empresário, enquanto gestor, e a maturidade da empresa, enquanto negócio.... $O$ empresário ele pode amadurecer na gestão de duas maneiras: uma maneira é na dor, ele vai tomar tanta pancada que ele será moldado e quando você olha, poxa, ele mudou completamente. Então ele amadurece porque ele vai perdendo muito, porque ele vai vendo o que está acontecendo ao redor dele, enfim, essa é uma forma dele amadurecer, ele foi na "marretadinha" do dia a dia, sofrendo e ele acaba: "Poxa vida, tenho que tomar esse outro passo porque aquele não está dando certo. " Mas eu acho que a ela maturidade também vem. (Especialista 10)

Para o Especialista 6, a informalidade e a centralização no dono da MPE são aspectos que podem ser melhorados com a profissionalização da gestão, a qual para o Especialista inclui a implantação de um orçamento formal para enxergar períodos a frente, de um fluxo de caixa e de treinamento de funcionários.

Alguns empresários não querem se distanciar totalmente do operacional para se dedicar exclusivamente à gestão, como é o caso da PAPN 8: "Mas também tem que ver o que você quer, eu não tenho essa vontade de ter um super escritório porque você acaba virando só administrador"

O perfil empreendedor também influenciará a busca por treinamentos externos, leituras e apoio especializado, como foi o caso da PAPN 1. Além disso, a formação do empresário também tem influência no seu modo de gerir. A Especialista 9 comentou ter encontrado empresários com formação acadêmica em administração, os quais mantinham práticas de controles operacionais e de gestão. Foi no curso de pós-graduação em que a PAPN 4 montou o plano de negócio de seu empreendimento, contando com a orientação e apoio de seus professores. Sobre a formação, o PAPN 5 expõe:

A gente percebe que, quando o comando da empresa é [ocupado] por uma pessoa que tem um nível de formação acadêmica mais alto, esse cara é mais sensível em entender [a importância d]esse tipo de planejamento a longo prazo. (PAPN 5)

A gestão do negócio foi o aspecto mais citado pelos entrevistados. Foi apontada uma série fatores que comprometem a gestão da MPE: o excessivo envolvimento no operacional com negligência da gestão, visão de curto prazo, falta de conhecimento em administração, decisões pautadas exclusivamente na intuição e falta de informação. De acordo com a 
Especialista 15, o principal problema de gestão dos PAPNs é a negligência da gestão do negócio para cuidado e preparo quase exclusivo com a parte operacional da empresa. Questão que também é recorrente nas pequenas empresas de base tecnológica incubadas, como relata o Especialista 5:

O empreendedor que está na [nome da incubadora], ou melhor, de base tecnológica, ele tem certamente um conhecimento profundo na parte tecnológica, no desenvolvimento do produto que é o foco da empresa dele, poucos são aqueles que têm alguma aptidão ou conhecimento de fazer esse controle interno. (Especialista 5)

Esse despreparo administrativo é chamado de 'amadorismo na gestão' pelos Especialistas 10 e 12 e é sintetizado pela falta de controles básicos, tais como fluxo de caixa, conhecimento do ponto de equilíbrio, rotinas mínimas de controles e planejamento. $\mathrm{O}$ Especialista 7 afirma que muitas vezes os PAPNs não têm informação, tem apenas dados e esses, isoladamente, não ajudam na tomada de decisão e, sem informação, o 'achismo' acaba sendo a bússola que orienta os rumos do negócio. Um exemplo disso pode ser destacado da fala da PAPN 7 quando questionada sobre a rentabilidade do seu negócio:

Porque é lógico, comida tem lucro porque o investimento é baixo, sabe assim? Você faz a conta na cabeça, não põe exatamente as coisas na ponta do lápis e eu acho isso uma dificuldade, não sei se é só para mim, mas é uma dificuldade. (PAPN 7)

A Especialista 10 indicou a dificuldade de planejamento como algo recorrente na MPE, o que para ela é algo da cultura do brasileiro em geral. O mesmo pode ser extraído da fala do PAPN 5:

Um ou outro [empresário] você percebe que a pessoa se programa. Na grande maioria não. Isso não é uma característica comum do brasileiro em geral quanto mais no empresarial. Isso reflete no empresariado, talvez isso que distinga os empresários de sucesso dos demais. Mas, não, isso não existe. O empresário brasileiro está muito preocupado com a próxima distribuição de urna [resultado das eleições], a sobrevivência dele ali imediata, não está preocupado em fazer um planejamento de longo prazo. Eu não vejo isso. (PAPN 5)

A PAPN 7 afirmou ter um planejamento de futuro, porém, informal, não escrito e para curtos espaços de tempo. Além disso, teria dificuldade de seguir o plano que estabelece: 
Na minha cabeça eu tenho um bom planejamento. Assim, não um planejamento total do que eu vou fazer mês a mês, nada disso. Mas a ideia que eu tenho aqui é de que a cada quinzena tivesse um evento que chamasse pessoas aqui. (PAPN 7)

Isso é outra dificuldade para mim, de ser, assim, de ter o que foi programado, o que foi projetado. Acho que projeto é a palavra certa, você se projetar, sentar antes, fazer um planejamento e fazer um esquema do que que vai ser feito e respeitar aquilo. (PAPN 7)

A PAPN 2, quando da entrevista, vivia um momento complicado em sua empresa de produção de conteúdo. Estava com dificuldades para captar novos clientes por causa da concorrência com as mídias sociais, via o risco de descontinuidade e reconhecia sua necessidade de apoio:

Então, é um momento de muita angústia. Apesar do ímpeto de nunca desistir, de sempre continuar, é um momento de muita angústia, de muito questionamento, de muita necessidade de assistência, muita carência nesse sentido de ter ajuda, não só financeira, como ajuda na gestão. (PAPN 2)

A empresária afirma ter desenvolvido as suas "parcas noções de administração na marra". No passado, mantinha alguns controles, inclusive de fluxo de caixa, segundo ela: "nada muito, assim, pensado, estratégico, profissional, nada com um método de gestão, administrativo, nada disso, foi uma coisa orgânica". Porém, com a queda do movimento empresarial, foi abandonando a rotina até deixar de fazê-la completamente.

Tal como a empresária acima, a PAPN 8 vive um momento de balanço do negócio: "Acho que faltou me estruturar direito, ter uma visão do negócio, como eu poderia pegar mais coisas e dar conta de tudo". Afirma que suas maiores dificuldades estão em saber como organizar o caixa, especialmente em momentos de baixo faturamento, e captar clientes. Sua apuração de custos e rentabilidade é intuitiva. Mantém controles rudimentares, apesar de já ter tentado informatizá-los de forma estruturada, porém, como a empresária anterior, também os abandou. Nas palavras dela:

Eu anoto em um papel, tipo tudo meio bagunçado [risos] e depois... eu estava passando para uma planilha assim: arquiteto-coordenador tem que gastar tantas 
horas no projeto, júnior tantas horas... Eu estava começando a fazer uma planilha dessas, mas, como eu não formatei muito, eu fui abandonando também isso. (PAPN 8)

A PAPN 8 declara ter dificuldades para dedicar-se à gestão, equilibrar o trabalho operacional com a organização e planejamento do futuro. Para ela, há ocorre um círculo vicioso:

E também fica aquela coisa assim, por exemplo, quando você está com muito trabalho, ai é o momento que você tem que se organizar. Na verdade, você tem que se organizar antes. Aí você tem que procurar o SEBRAE e essas coisas, mas você não tem tempo. E você não tem tempo porque você não soube se organizar, sabe? (PAPN8)

A empresária sente-se paralisada em momentos sem trabalho, não conseguindo investir o tempo em organização e planejamento:

Eu fico assim: "Meu Deus, o que é que eu faço? ”. Tentando achar trabalho, tentando achar algum trabalho e não consigo relaxar e pensar assim: "Estou procurando trabalho, estou fazendo o que é possivel, vou aproveitar esse tempo para me organizar, para me preparar". Eu fico simplesmente paralisada. Eu só consigo pensar em captar trabalho, eu não consigo pensar que aquele tempo eu posso usar para me organizar. É uma coisa meio maluca isso aí. (PAPN 8)

Os Especialistas 7 e 8, ambos proprietários de escritórios contábeis, criticaram a postura de PAPNs que externalizam a culpa em vez de aprimorarem suas habilidades de gestão:

Eu chamo de terceirização da culpa, a culpa não é minha nunca. O cara é lócus externo, ele quer pôr a culpa em alguém. Então é o governo, é a carga tributária, é o concorrente. (Especialista 7)

Mas o administrador que não é empreendedor já tenta externalizar a culpa ...por exemplo, eu tenho clientes aqui que chegam, abrem uma empresa achando que vão ganhar dinheiro. Ele não tem perfil de empreendedor, ele joga quase toda a responsabilidade na tua mão e o contador acaba tendo uma certa responsabilidade.... A gente leva muita culpa, porque os caras querem 'toda culpa é do contador, toda culpa é do contador', sabe? (Especialista 8) 
É comum, dentre os PAPNs que mantêm rotinas administrativas e de gestão, o uso de relatórios próprios, desde planilhas eletrônicas até anotações em cadernos, sem utilização das informações geradas pela contabilidade, quando as recebem, como afirmaram os Especialistas 11 e 13. Inclusive administradores com gestão profissional pouco utilizam a contabilidade para suportar suas decisões, como é o caso do PAPN 6, quem afirmou utilizar para isso seus relatórios gerenciais próprios, bem como o PAPN 3, que utiliza seus relatórios para ações preventivas, utilizando a contabilidade, em especial a Demonstração de Resultados, para correção de erros.

Para a Especialista 15, os PAPNs têm consciência da importância da profissionalização da gestão: "Ele [o PAPN] vê necessidade, ele sabe que se se profissionalizar ele consegue ter um resultado melhor. "No mesmo sentido, os PAPNs entrevistados com dificuldades na gestão de suas empresas reconheciam suas limitações e a importância de desenvolver competências administrativas, como foi o caso das PAPNs 2, 7 e 8. A PAPN 8 vê a possibilidade de encontrar um sócio administrador como forma de suprir suas deficiências na área. Apesar dessa possibilidade declara:

Mas eu sei que mesmo eu tendo um escritório pequeno, sei lá, eu quero atingir uma equipe de cinco, seis pessoas. Eu sei que eu tenho que aprender a gerir isso, mesmo que depois eu tenha um sócio que, eu acho que é importantíssimo isso também, mesmo sendo pequena. (PAPN 8)

A busca por sócios com expertises complementares, especialmente em administração, é um dos caminhos indicados pelo Especialista 13 para a superação de limitações. A formação em administração ou negócios pode ser um diferencial na gestão da MPE, como no caso dos PAPNs 3, 4, 5 e 6. Porém, há empresários que buscam conhecimento e aperfeiçoamento da gestão, ainda que através da prática, como é o caso da PAPN 1 que afirma ter sido seu primeiro negócio o seu laboratório de gestão e controles. Segundo ela, à medida que "negócio vai ampliando o tamanho, os controles vão se fazendo necessários de outras formas". Assim como foi um aprendizado prático a condução dos dois negócios que o Especialista 13 teve antes de se tornar Professor e Consultor.

A Especialista 8 compartilhou a vivência com um cliente que ela classifica como "administrador mesmo" e que faz uso dos recursos oferecidos pela contabilidade como suporte para suas decisões: 
Eu tenho um cara que é dono de uma logística, o cara é o verdadeiro empreendedor. Ele é formado em administração, ele trabalha como consultor da [nome da empresa]. Ele teve a maior oportunidade de uma transportadora [relato da operação]. Só por ele ter essa articulação, com essa visão, ele já conseguiu a empresa dele. E na empresa dele, para você ter uma noção, ele controla tudo, ele tem planilha de tudo, ele controla onde o cara está, o que o cara está fazendo, ele faz provisão para férias, faz provisão para $13^{\circ}$, ele faz tudo que a contabilidade oferece, tudo que a gente oferece para o cliente, ele utiliza e utiliza da melhor forma para administrar a empresa dele. Não é à toa que ele está em ascensão. Não tem como ele se dar mal no mercado. Se ele vê que está em declínio ele já está ali. Ele é flexível, ele é o administrador mesmo. Então, é muito diferente aí de empresários que não têm esse conhecimento e não querem ter, querem cuidar do dia a dia, não querem cuidar da administração, querem cuidar do operacional. (Especialista 8)

Porém, duas PAPNs, sem formação em administração ou áreas afins, afirmaram não ter conhecimento sobre o que realmente poderiam esperar da contabilidade ou do contador. Afirmaram, ainda, não saber até onde a contabilidade poderia ir para ajudar o negócio, para além das rotinas de apuração de tributos:

Eu realmente não sei no que ele poderia me ajudar mais porque eu não sei no que ele [o contador] seria capaz de me ajudar mais além disso .... É que eu não entendo muito bem até onde ele pode ir, entendeu? .... Essa coisa de depender e a gente não saber direito o que consegue fazer sozinha e o que realmente o contador precisa fazer. Não está claro assim. Para mim, na verdade, acho que para a maioria das pessoas, não está muito claro o que o contador precisa fazer. (PAPN 8)

Eu não sei mais se caberia ao escritório de contabilidade, entende? Por exemplo, essa coisa da orientação no sentido de pensar o negócio de forma a longo prazo, no sentido de projeção. Eu acho que isso é uma coisa muito interessante porque a gente acaba enxergando o escritório de contabilidade no imediato da coisa, o que eu tenho que pagar para o próximo mês, que tributo que eu tenho que pagar, né? (PAPN 1)

Embora existam casos de empresários de sucesso que construíram grandes negócios sem terem tido uma administração profissional quando ainda eram pequenos, como lembra o Especialista 6, algumas práticas básicas de gestão são essenciais para a sobrevivência do 
negócio, afirma o Especialista 13, tais como análises financeiras, projeção de fluxo de caixa, controle de capital de giro e conhecimento do ponto de equilíbrio.

Outras boas práticas de gestão foram referenciadas nas falas dos sujeitos da pesquisa e podem ser sintetizadas como:

- Busca por capacitação, aprimoramento e inovação (Especialista 12)

- Planejamento do futuro, simulação de cenários e análise de retorno do investimento (Especialista 10)

- Controle de processos e rotinas (Especialista 8)

- Inovação com atenção crítica aos modismos (Especialista 10)

- Busca por financiamentos e proatividade para renegociar dívidas, quando necessário (Especialista 13)

- Entendimento dos riscos associados a decisões (Especialista 7)

- Uso da informação contábil para a tomada de decisão (Especialista 8)

O Especialista 3 define o empreendedor como um corajoso. Para ele, "tem que ter coragem para partir para o desafio. "O Especialista 4 relembra a época em que foi empresário de uma microempresa e afirma que "não é uma rotina fácil." E, em meio a tantos desafios e dificuldade, esses PAPNs sentem-se sozinhos:

O empreendedor atua muito solitariamente. Ele tem que buscar as informações por conta própria e mesmo quando busca órgãos como o SEBRAE, por exemplo, encontra suporte de quem não tem experiência como empreendedor. Na melhor das hipóteses, quem vai lhe atender é um professor, um estudioso sobre o assunto, o qual lhe dará dicas sobre a parte formal/burocrática do empreendimento, tais como: ter espaço, formalizar, pagar impostos etc., mas somente a prática é quem lhe trará as respostas necessárias. (PAPN 6)

Eu sinto muita falta de ter um sócio, talvez nem seja um arquiteto, talvez seja uma pessoa mesmo para administrar, para captar cliente, para gerir essa parte toda, para dividir os bons e os maus momentos. (PAPN 8)

A minha mãe é minha sócia ... me ajuda a tomar algumas decisões. Mas no dia a dia eu estou cada dia mais sozinha. (PAPN 2) 


\subsection{Aspectos associados ao Contexto das MPEs}

À categoria 'Contexto das MPEs' foram associadas 15 subcategorias que receberam 122 nós durante a codificação axial associados ao ambiente no qual atuam os Proprietários Administradores de Pequenos Negócios. Os comentários dos entrevistados se concentraram em situações acerca das dificuldades enfrentadas por essas empresas em um ambiente desfavorável a suas particularidades. As subcategorias e a quantidade de nós que cada uma recebeu são apresentadas na Tabela 11:

Tabela 11: Subcategorias e nós associados ao Contexto da MPE

\begin{tabular}{|c|c|c|c|c|c|c|c|c|c|c|c|c|c|c|c|c|c|c|c|c|c|c|c|c|c|}
\hline Categoria e Subcategoria & $\begin{array}{l}\mathbf{E} \\
\mathbf{1}\end{array}$ & $\begin{array}{l}\mathbf{E} \\
2\end{array}$ & $\begin{array}{l}\mathbf{E} \\
\mathbf{3}\end{array}$ & $\begin{array}{l}E \\
4\end{array}$ & $\begin{array}{l}\mathbf{E} \\
\mathbf{5}\end{array}$ & $\begin{array}{l}E \\
6\end{array}$ & $\begin{array}{l}\mathbf{E} \\
7\end{array}$ & $\begin{array}{l}\mathbf{E} \\
\mathbf{8}\end{array}$ & $\begin{array}{l}\mathbf{E} \\
\mathbf{9}\end{array}$ & $\begin{array}{c}\mathbf{E} \\
10\end{array}$ & $\begin{array}{c}E \\
11\end{array}$ & $\begin{array}{r}E \\
12\end{array}$ & $\begin{array}{c}E \\
13\end{array}$ & $\begin{array}{c}E \\
14\end{array}$ & $\begin{array}{c}E \\
15\end{array}$ & $\begin{array}{c}E \\
16\end{array}$ & $\begin{array}{l}\mathbf{P} \\
\mathbf{1}\end{array}$ & $\begin{array}{l}\mathbf{P} \\
\mathbf{2}\end{array}$ & $\begin{array}{l}\mathbf{P} \\
\mathbf{3}\end{array}$ & $\begin{array}{l}\mathbf{P} \\
4\end{array}$ & $\begin{array}{l}\mathbf{P} \\
\mathbf{5}\end{array}$ & $\begin{array}{l}P \\
6\end{array}$ & $\begin{array}{l}\mathbf{P} \\
7\end{array}$ & $\begin{array}{l}\mathbf{P} \\
8\end{array}$ & $\sum$ \\
\hline Contexto MPE & 3 & 4 & 2 & 12 & 8 & 5 & 8 & 16 & & 7 & 1 & 2 & 6 & 1 & 1 & & 1 & 7 & & 6 & 1 & 3 & 14 & 14 & 122 \\
\hline $\begin{array}{l}\text { Dificuldades enfrentadas } \\
\text { pela MPE }\end{array}$ & 3 & & & 2 & 2 & 3 & 3 & 2 & & 2 & & & 2 & 1 & 1 & & & 3 & & 1 & 1 & 2 & 10 & 6 & 44 \\
\hline $\begin{array}{l}\text { Regime tributário } \\
\text { simplificado }\end{array}$ & & & & & 4 & & 2 & 7 & & & & & & & & & & 3 & & & & & & 5 & 21 \\
\hline $\begin{array}{l}\text { Ambiente desfavorável à } \\
\text { MPE }\end{array}$ & & 1 & & 2 & & & & 5 & & & & 1 & 1 & & & & & & & & & 1 & & 1 & 12 \\
\hline $\begin{array}{l}\text { Mudanças de cenários de } \\
\text { mercado (Dificuldades e } \\
\text { Oportunidades) }\end{array}$ & & & & & 1 & & & & & 1 & & & 1 & & & & & 1 & & 2 & & & & 2 & 8 \\
\hline $\begin{array}{l}\text { Mortalidade e } \\
\text { Sobrevivência da MPE }\end{array}$ & & & & 1 & 1 & 1 & & & & 2 & & & & & & & & & & 1 & & & & & 6 \\
\hline Confusão entre PJ e PF & & & & & & & 1 & & & 1 & & 1 & & & & & & & & 1 & & & 1 & & 5 \\
\hline Definição de MPE & & & & 2 & & & & 1 & & 1 & 1 & & & & & & & & & & & & & & 5 \\
\hline Formalização & & & & & & & & & & & & & 1 & & & & & & & 1 & & & 3 & & 5 \\
\hline $\begin{array}{l}\text { Credores avaliam o crédito } \\
\text { com base na c/c, como PF }\end{array}$ & & & & 4 & & & & & & & & & & & & & & & & & & & & & 4 \\
\hline $\begin{array}{l}\text { Informatização do governo } \\
\text { X Sonegação }\end{array}$ & & & 1 & & & & 2 & 1 & & & & & & & & & & & & & & & & & 4 \\
\hline $\begin{array}{l}\text { Impacto econômico da } \\
\text { MPE }\end{array}$ & & & 1 & 1 & & 1 & & & & & & & & & & & & & & & & & & & 3 \\
\hline $\begin{array}{l}\text { Usuário está dentro da } \\
\text { empresa, utiliza relatórios } \\
\text { próprios }\end{array}$ & & 1 & & & & & & & & & & & & & & & 1 & & & & & & & & 2 \\
\hline $\begin{array}{l}\text { Contabilidade Societária } \\
\text { feita por obrigatoriedade }\end{array}$ & & & & & & & & & & & & & 1 & & & & & & & & & & & & 1 \\
\hline $\begin{array}{l}\text { Pouca exposição ao usuário } \\
\text { externo }\end{array}$ & & 1 & & & & & & & & & & & & & & & & & & & & & & & 1 \\
\hline Treinamento para PAPN & & 1 & & & & & & & & & & & & & & & & & & & & & & & 1 \\
\hline
\end{tabular}

Fonte: Elaborado pela Autora (E = Especialista e P $=$ PAPN)

Aos Especialistas foi questionado o que entendiam por uma microempresa ou uma empresa de pequeno porte. Aqueles envolvidos com a Academia utilizam as definições de porte do SEBRAE, da Receita Federal do Brasil e do BNDES, enquanto os proprietários de escritórios contábeis apresentavam critérios próprios diversos, exceto a Especialista 8 quem utiliza o critério de enquadramento fiscal para definir o tamanho de seus clientes. Já os 
Especialistas 7 e 11 mantêm critérios vinculados ao volume de trabalho demandado pelo cliente, medido por quantidade de lançamentos, notas fiscais, número de funcionários etc.

O ambiente de negócios brasileiro é pouco favorável às MPEs e são muitos os desafios enfrentados por essas empresas em busca da sobrevivência e crescimento. Esse é o grande contexto da MPE de acordo com as falas dos Especialistas e PAPNs entrevistados. Com recursos escassos, conforme Especialista 2, essas empresas lidam com a morosidade de serviços públicos para regularização de pendências, de acordo com o PAPN 6 e, embora tenham ocorrido avanços no sentido de oferecer o tratamento diferenciado que esses negócios têm garantido pela Constituição Brasileira com a ampliação da Lei Geral da MPE, são apontadas pelos Especialistas circunstâncias em que a pequena empresa é prejudicada. A Especialista 8 comenta a experiência de um cliente que não conseguiu iniciar um empreendimento por causa da licença ambiental, porém, não lhe foi oferecido apoio ou alternativas, enquanto multinacionais recebem subvenções para instalarem-se em áreas originalmente de preservação. Além desse exemplo, a Especialista menciona o caso de clientes que foram obrigados a implantar sistemas informatizados para emissão de nota fiscal eletrônica em região onde não havia infraestrutura para conexão de internet, o que the pareceu uma cobrança ao contribuinte sem o devido suporte. A desvantagem no acesso a crédito e na participação em licitações também apareceu:

Empresa de porte médio tem acesso a linhas de crédito mais altas, ela tem acesso a programas de incentivo governamental bem mais amplos do que uma micro e pequena empresa ... nossos próprios clientes comentavam que queriam participar de uma licitação específica, mas que o porte da empresa deles não privilegiava isso. (Especialista 12)

Os pequenos negócios têm importante impacto na geração de empregos, lembra o Especialista 4, e podem ser as grandes empresas do futuro, visto que as grandes corporações de hoje nasceram pequenas, como reforça o Especialista 3. Apesar dessa importância, a sobrevivência é uma preocupação quotidiana na vida das microempresas: "vejo uma luta diária pela sobrevivência", diz o Especialista 4, quem também empreendeu um pequeno negócio no passado. A Especialista 10 exemplifica a situação:

Ele vive pagando as contas, ele está vendendo o almoço para comprar a janta. Infelizmente é assim! Primeiro eu vejo se eu consegui pagar todos os meus 
funcionários, então eu compro isso, pago aquilo, pago aquilo outro, eu vejo o que vai vender amanhã, o que vai vencer depois de amanhã e ele vive assim durante um tempo. (Especialista 10)

Esse imediatismo exigido pela luta por sobrevivência é evidenciado na fala da PAPN 2:

Porque eu só estou pensando como que eu vou pagar a conta de amanhã, que que eu vou fazer para reinventar a minha empresa e para pegar mais contratos, mais clientes, prospectando e arrumando web site, atualizando e mandando newsletter $e$ fazendo networking. Eu não tenho cabeça para parar e pensar nessa, nesse lado organizacional. (PAPN 2)

Para o Especialista 5, existe uma seleção natural do mercado especialmente nas empresas tecnológicas com que atua. A Especialista 10 afirma que apesar da mortalidade, muitas são as MPEs que "vão para frente". O Especialista 6 defende que não se trata de um problema, mas de uma característica desse segmento:

Eu falei que acho bem complicado chamar de problema. Por quê? Porque apesar de a taxa de mortalidade ser alta, muitos deles sobrevivem e constroem impérios, não é? Por isso eu não chamaria de problema, chamaria de característica. (Especialista 6)

A PAPN 4 viu na alta mortalidade do segmento em que atua, alimentação, como uma oportunidade de venda do seu produto: assessoria administrativa. $\mathrm{O}$ aproveitamento das oportunidades é algo que exige conhecimento do mercado de atuação, como afirmou o Especialista 13, e o PAPN precisa atentar-se para o impacto das mudanças de mercado em seu negócio, como na visão da Especialista 10, o que pode ser mais difícil para alguns empresários, como é o caso da PAPN 2 que está tentando "se reinventar". A PAPN 8 repensa seu posicionamento de mercado e enxerga a especialização como uma saída para seu negócio porque, segunda ela, a arquitetura é uma das primeiras a sofrer com crises econômicas:

O que eu hoje vejo é que mais do que ser um bom profissional, bons profissionais existem aos montes, eu preciso, é isso que eu estou começando a correr atrás, eu preciso mesmo me especializar, que é um diferencial, que é uma coisa assim no estilo de uma consultoria, tipo, as pessoas que me procuram, elas procuram a [nome da PAPN 8] porque ela é especializada em tal coisa e a gente quer ouvir a opinião dela para isso. E aí eu consigo cobrar um preço pelo saber, porque pela mão de obra, para fazer um 
projeto, uma coisa assim, existem mil arquitetos que cobram menos do que eu ou cobram tanto quanto e são tão bons. (PAPN 8)

A concorrência, assim como nas empresas de grande porte, é algo que está no radar de atenção desses empresários. Como colocado acima pela PAPN 8, existe a concorrência por preços de produtos facilmente copiáveis entre pares. Porém, a maior dificuldade é a concorrência com grandes empresas de marcas consolidadas como aponta a PAPN 7:

Eu fiz um bazar agora na Procuradoria do Estado de são Paulo, um bazar de Páscoa, foi quinta e sexta passada. É um público classe média alta, embora tenha de tudo lá dentro, mas a gente está concorrendo com Munique, Ofner, né? (PAPN 7)

Uma prática comum nas pequenas empresas é a mistura de operações dos sócios, pessoas físicas, com as operações da empresa, a pessoa jurídica. Esse cenário foi mencionado pelos Especialistas 7, 12 e é sintetizado na fala apresentada a seguir, da Especialista 10:

Eles têm muita dificuldade em fazer separação, por exemplo, entre a vida da empresa e a vida pessoal. Então, os planos empresariais, do negócio, acabam se misturando com os planos pessoais. Isso é muito comum na realidade que eu tenho enfrentado lá com esses pequenos empresários. E eles não têm muita habilidade para fazer um planejamento separado, olhar a empresa e a ver como um outro organismo. Isso é uma coisa muito forte. (Especialista 10)

Além dos Especialistas, a PAPN 4, cujo negócio envolve terceirização de serviços administrativos, também menciona que, com frequência, encontra administradores que "confundem as contas pessoais com contas empresariais." De acordo com o Especialista 2, comumente, as MPEs mantêm "contabilidades que misturavam conceitos do dono com o da entidade. Contabilidades que, pouco ou nada guardavam o conceito de competência”, o que foi evidenciado na fala da PAPN 1:

Agora, essas rotinas de caixa, eu até mando para a contabilidade o nosso, o que a gente fez, as notas fiscais, tudo. Eu mando para a contabilidade, elas têm um nível de controle lá. Mas o caixa que eu uso aqui é totalmente diferente do que elas fazem lá. (PAPN 1)

Quando questionada sobre o uso dos relatórios recebidos da contabilidade, a PAPN 1 afirmou: "Nunca usei porque não corresponde à realidade das coisas aqui da escola. " 
A contabilidade societária ou financeira também é pouco utilizada pelos empresários da MPE por três outras razões:

(i) $\mathrm{O}$ principal usuário da informação, o Gestor, tem acesso completo às informações e utiliza relatórios próprios para a tomada de decisão:

Não havia interesse do proprietário em fazer uma contabilidade de qualidade, já que ele era o único usuário e esse conseguia informações em outros relatórios gerenciais internos para tomar decisão. (Especialista 2)

(ii) Comum omissão de receita para redução de tributos faz com que a contabilidade oficial não represente a realidade:

Um sistema de financiamento de crédito tem alguns parâmetros contábeis também, de receita, faturamento e, quando bate aqui, o dado prejudica porque a empresa sempre quer que a sua contabilidade dê a menor possível, eu tenho essa a impressão, ele quer ter o menor faturamento para pagar menos tributo, toda aquela diferença de tributação, então isso na hora que ele vai acessar o crédito acaba prejudicando, porque aquela empresa, na verdade, ela é maior do que o número contábil está dizendo. (Especialista 4)

(iii) Pouca exposição a usuários externos:

[A contabilidade de MPE é] uma contabilidade que nunca havia sido exposta a uma necessidade externa, não reportava a ninguém. Na melhor das hipóteses, eles [os PAPNs] tinham entregue um balancete para algum banco, impetrando algum crédito, mas na verdade eram contabilidades muito, muito pouco úteis para usuários externos. (Especialista 2)

No cenário do pequeno negócio, a figura do contador está associada à formalização do negócio e ao recolhimento de tributos. A PAPN 7 ainda não está com o negócio formalizado e não tem contador, por exemplo. O Especialista 13 também não procurou esse profissional em situação similar:

Foi assim, nasceu, começou, não durou nem um ano, não deu tempo nem de formalizar o negócio, não deu tempo de abrir CNPJ, não deu tempo de nada. Portanto, não tivemos um contador. (Especialista 13) 
As duas empresárias com filhos citaram situações que remetem ao impacto da maternidade no equilíbrio do tempo dedicado ao negócio e à vida familiar. A múltipla jornada, mãe, dona de casa e empresária, aparece na fala da PAPN 7 quando compara sua dedicação com a das outras sócias:

Enfim, não é justo eu ficar mais tempo à mercê do meu trabalho de casa com filho. Ele vem junto o nenê para cá. É uma dificuldade para você trabalhar, mas aí também é uma opção, né? Uma opção que eu fiz também. Que veio diante da necessidade e da falta de recurso, eu não tenho recurso financeiro para ter outra opção também [risos]. (PAPN 7)

A empresária reforça o impacto de sua múltipla jornada e da falta de recursos para conseguir ajuda externa no cuidado com a casa e o filho pequeno nas suas atividades de gestão:

A grana sempre está presente, né? Porque não tem esse dinheiro para fazer essas coisas. Na minha vida pessoal, por exemplo, eu agora não sei se pode misturar um pouco. Mas eu não fico mais tempo aqui porque em casa eu estou sozinha, faço faxina. Então a hora que eu estou aqui, eu desço, paro um pouco, é muito perto da minha casa. Então, tenho demanda com o nenê, ele não foi para a escola ainda porque também a gente está sem grana para pagar uma escola ou alguém que fique com ele. Isso para mim, ser mãe, ser dona de casa, [e empreendedora] essas três jornadas, não é fácil. Isso para a mulher é uma coisa complicada de se trabalhar... Se tivesse alguém na minha casa, por exemplo, eu tenho uma faxineira uma vez por semana, entendeu? Então, também isso gera indiretamente um estresse, até porque eu não estou conseguindo me dedicar mais ao próprio projeto aqui, né? Eu podia ter mais tempo para pensar. Quando eu chego aqui, é execução. Eu não tenho tempo de planejamento. Você entendeu? (PAPN 7)

A PAPN 8 também expôs que vinha em uma curva de muito trabalho até o nascimento de seu bebê, quando voltou a trabalhar em escritórios:

Foi até o começo de 2014 que eu ainda estava nesse ritmo e eu precisava me estruturar para conseguir fazer a empresa virar. Mas só que aí eu me atrapalhei toda em 2014, ainda até estou tentando buscar uma rotina agora com filho pequeno. E eu estou agora de novo prestando serviços, estou trabalhando aqui em um outro 
escritório, fazendo, pegando coisas menores no escritório, num horário como freela [freelance] porque eu acho que faltou me estruturar direito, ter uma visão do negócio, como eu poderia pegar mais coisas e dar conta de tudo, enfim. Mas é isso, eu quero voltar, agora eи estou em um momento que eu preferi trabalhar para os outros, como eu trabalho de 9 às 18 horas, tenho aquele dinheiro certo e eu tenho esse tempo de me reestruturar e ai de novo eu estou pensando como [fazer isso]. (PAPN 8)

Os conflitos e dificuldades de relacionamento com sócios foram citado por três entrevistados, dois empresários e um especialistas, remontando a uma experiência passada como empresário. Em duas situações, esses conflitos levaram ao fim do empreendimento, como foi o caso da PAPN 7, que depois da experiência afirma que se trata de "administrar egos ... você tem que lidar com egos". Porém, a sociedade também é abordada como uma oportunidade para suprir deficiências de conhecimento, de acordo com a PAPN 8 e amenizar a sensação de solidão na condução dos negócios, como indicado pelas PAPNs 2 e 8 .

Os tributos são um assunto recorrente no contexto da MPE, especialmente a prática de omissão de receita para redução de recolhimento de impostos. Para o Especialista 3, parte dos negócios são tratados na informalidade:

Como temos uma legislação extremamente complexa, há de convir que uma outra realidade, que você não pode esconder do seu trabalho, é que parte da pequena e microempresa no Brasil trabalha na informalidade, boa parte do seu trabalho é na informalidade. (Especialista 3)

Os Especialistas 7 e 8 argumentam que os arranjos para enquadramento indevido ou a sonegação estão cada vez mais difíceis de serem mantidos devido à informatização dos governos. A Especialista 8 explica que há uma diferença muito grande entre os regimes tributários e enxerga nisso um fator inibidor de crescimento ou estimulador de sonegação:

É limitador porque, assim, o cara poderia até expandir a empresa dele, ele poderia falar: "Não, hoje eu vou abrir um SIMPLES". Mas ele sabe que vai pagar mais tributo, só que ele pensa assim: "Ah, eu acho que, para mim, $R \$ 12.000,00$ está bom, estou ganhando $R \$ 12.000,00$ por mês, acho que está bom para mim, acho que vou ficar aqui e pagar esses $R \$ 32,00$ de INSS, vou me aposentar lá na frente". Vai ficar ai. (Especialista 8) 
Tem muito cara abrindo MEI, aí um MEI, beleza, você fala: “Ah, abre, o CNPJ sai na hora”. Você está pagando aquele 'tributinho', beleza, $R \$ 32,00$ por mês a título de INSS e paga um pequenininho lá de ISS e o cara fica MEI em R\$ 5.000,00 por mês que você pode faturar e o cara vende mais cinco no caixa 2 [sem registro contábil], que não vai passar no cartão de crédito porque de crédito pega, a Receita Federal vai saber e fica ali. Que nem eu te falei, um fator limitador, ele não vai querer sair daquilo ali, para ele está bom, ele vai faturar de dez, doze mil por mês, para ele está ótimo. (Especialista 8)

Para manterem-se competitivos no mercado, dada a grande diferença de escala no tratamento tributário entre um regime e outro mencionada acima, a Especialista 8 aponta que algumas médias empresas procuram fazer arranjos, muitas vezes a contragosto do contador, para continuarem no regime tributário simplificado destinado a EPPs. Para alguns negócios, tal regime é a única forma de manterem-se viáveis, como relata a PAPN 2:

Era um Deus nos acuda, um pega-pra-capa, porque a gente também não pagava os impostos, a gente não era microempresa no começo, eram $28 \%$ de impostos, era um negócio super inviável, tanto que até hoje eu pago dívidas desses impostos, dividas que são pesadas hoje em dia ... o fato de a gente não poder ser uma ME, não existia SIMPLES ainda, nossa! Foi um negócio assim draconiano. A gente simplesmente não tinha dinheiro para pagar os impostos. Não tinha! Não tinha nem de onde tirar mais! ... E hoje eu estou pagando impostos que eu parcelei para poder entrar no SIMPLES ... porque eu não posso sair do SIMPLES, se a gente sair do SIMPLES, assim, acabou para nós. Ai eu não sei o que fazer. [Fala final com emoção nítida] (PAPN 2)

A Especialista 8 critica as diferenças entre um regime tributário e outro e defende um regime tributário único e gradativo:

Se você tem [tivesse] um regime tributário único, para todas as empresas, todas, sem distinção de porte, sem distinção de ramo, sem distinção de nada, um único regime tributário em que deixe que qualquer empresário se iguale de acordo com o caminhar, entendeu, que o imposto seja gradativo, de acordo com o faturamento dele, com a expansão dele ele vai pagar mais tributo, com expansão gradativa. (Especialista 8)

O regime tributário simplificado para as MPEs traz facilidades para o dia a dia do contador que atende essas empresas. O Especialista 5 atua com empresas que passam longo 
tempo inicial sem faturamento e percebe que os contadores dessas empresas as enquadram em regimes simplificados porque isso facilita o trabalho nesse período, mesmo que não pudessem, porém alerta:

Num primeiro momento, até não é ruim porque ele está com a empresa constituída, ele pode transacionar com a FAPESP, pedir um projeto, conversar com a CNPq, ele pode fazer as aquisições de que precisa, mas vai chegar um momento que vai dar problema ... não é que a gente fica procurando chifre na cabeça de cavalo. Às vezes, é preferivel a gente saber que esse cavalo aí, na verdade, pode ser boi e pode nascer um chifre daqui a pouco .... Então saiba que daqui X tempo, você tem que se preocupar com isso. (Especialista 5)

A realidade acima mencionada pelo Especialista 5 refere-se a um período anterior a recente mudança na Lei Geral da MPE que ampliou os tipos de empresas possibilitadas ao enquadramento no regime simplificado. Sobre essa mudança, o Especialista 7 critica seu formato, contando que depois de fazer simulações a pedido de seus clientes, o efeito não foi o esperado:

É que nessa nova conta, das pessoas que me pediram para fazer uma simulação, eu fiz com dados de 2014 aplicando o anexo que começa, não dava. Não dava. A maioria ou ia ficar igual ou ia pagar mais. (Especialista 7)

Outra situação que foi apontada como um dificultador do desenvolvimento da MPE é a corrupção institucionalizada em alguns mercados. A Especialista 8 comentou casos em que o planejamento de custos do cliente tinha que considerar valores de propinas, pois no mercado de atuação da empresa, quem não bancasse esse sistema, não trabalharia. A Especialista comenta a complicada equação para planejamento tributário de empresas que vivem sob essa circunstância:

Digamos, você vai colocar o regime do lucro real, sendo que a maior parte do contrato deles vai para o lobista ... os caras têm isso no mercado, no Brasil é assim. (Especialista 8)

Para o Especialista 6, "a falta de capital, a falta de recursos financeiros e tecnológico" é algo comum nos pequenos negócios. Contribuindo para a dificuldade financeira, o estoque encalhado era uma das reclamações recorrentes dos PAPNs à Especialista 1, quando atuava 
como consultora desse público. Essa foi uma das principais razões para a primeira empresa do Especialista 13 ter falido. Ele relatou:

Quando a gente viu que o negócio estava bombando, que o negócio estava dando certo, resolvemos fazer um pedido enorme para o inverno e acabou encalhando, malhas, agasalhos porque não fez frio no inverno naquele ano. Encalhou tudo e em algum momento o fornecedor pediu nossa falência porque a gente não conseguia mais pagar os nossos fornecedores de malha. (Especialista 13)

A falta de recurso financeiro é mencionada pela PAPN 7 como impeditivo para divulgação adequada de seu negócio e pela PAPN8 como impeditivo para contratar mão de obra:

Investimento para fazer marketing: eu tenho dificuldade. Eu não tenho tanto dinheiro para ficar colocando anúncios na própria rede ou fazer uma revista ou coisa assim e aí eu tenho que pagar o preço por só aparecer por indicação, em rede social e aqui panfletando na região. (PAPN 7)

Você era pequenininho e aí começa a entrar trabalho e você: "E agora? ". Aí você perde o bonde, porque você não consegue pegar todos os trabalhos que te oferecem porque você não tem equipe. Mas aí como você faz? Você contrata gente antes na esperança de ter trabalho? Como é que você sustenta isso? Isso para mim é o mistério da humanidade [risos]. (PAPN 8)

Os problemas enfrentados pelas PMEs são os mesmos de 30 anos atrás, é o que conclui o Especialista 14, que produziu um dos primeiros trabalhos no Brasil sobre a tipologia de problemas enfrentados por essas empresas. Em consonância com tal afirmação, a Especialista 1, remontando ao seu passado como consultora do SEBRAE, afirma que: "as dificuldades que [ela] eu ouvia naquele tempo são as mesmas de hoje."

\subsection{Aspectos associados ao Escritório Contábil e aos Profissionais de Contabilidade}

As questões relacionadas ao escritório contábil e aos profissionais contábeis que atuam com a MPE compuseram a segunda categoria mais referenciada pelos entrevistados, recebendo 176 nós de acordo com a codificação axial. O conjunto dessas categorias e subcategorias, bem como suas evocações por entrevistado são apresentados a seguir na Tabela 12: 
Tabela 12: Subcategorias e nós associados ao Escritório Contábil

\begin{tabular}{|c|c|c|c|c|c|c|c|c|c|c|c|c|c|c|c|c|c|c|c|c|c|c|c|c|c|c|}
\hline Categoria e Subcategoria & $\begin{array}{l}\mathbf{E} \\
1\end{array}$ & $\begin{array}{l}\mathbf{E} \\
2\end{array}$ & $\begin{array}{l}\mathbf{E} \\
\mathbf{3}\end{array}$ & $\begin{array}{l}\mathbf{E} \\
\mathbf{4}\end{array}$ & $\begin{array}{l}\mathbf{E} \\
\mathbf{5}\end{array}$ & $\begin{array}{l}\mathbf{E} \\
6 \\
\end{array}$ & $\begin{array}{l}\mathbf{E} \\
7\end{array}$ & $\begin{array}{l}\mathbf{E} \\
\mathbf{8}\end{array}$ & $\begin{array}{l}\mathbf{E} \\
9\end{array}$ & $\begin{array}{c}\mathbf{E} \\
10\end{array}$ & $\begin{array}{c}E \\
11\end{array}$ & $\begin{array}{c}\mathbf{E} \\
12\end{array}$ & $\begin{array}{c}E \\
13\end{array}$ & $\begin{array}{c}E \\
14\end{array}$ & $\begin{array}{c}E \\
15\end{array}$ & $\begin{array}{c}E \\
16\end{array}$ & $\begin{array}{l}\mathbf{P} \\
1\end{array}$ & $\begin{array}{l}\mathbf{P} \\
\mathbf{2}\end{array}$ & $\begin{array}{l}\mathbf{P} \\
\mathbf{3}\end{array}$ & $\begin{array}{l}\mathbf{P} \\
4\end{array}$ & $\begin{array}{l}\mathbf{P} \\
5\end{array}$ & & & $\begin{array}{l}\mathbf{P} \\
7\end{array}$ & $\begin{array}{l}\mathbf{P} \\
\mathbf{8}\end{array}$ & $\sum$ \\
\hline Escritório Contábil & 5 & 1 & 7 & 3 & 8 & 4 & 45 & 32 & 2 & 4 & 9 & 4 & 7 & 1 & 4 & & 6 & 3 & 10 & 7 & 5 & & 2 & & 7 & 176 \\
\hline $\begin{array}{l}\text { Dinâmica do Escritório } \\
\text { Contábil }\end{array}$ & 1 & & 2 & & 4 & 1 & 19 & 25 & & 1 & 4 & 4 & 2 & & & & 1 & & 5 & 2 & 1 & & & & & 72 \\
\hline $\begin{array}{l}\text { Despachante de Impostos e } \\
\text { Folha }\end{array}$ & 1 & & 1 & 1 & 1 & 3 & 7 & 2 & 2 & 1 & 2 & & 1 & & 1 & & 4 & 2 & 3 & 1 & 2 & & 2 & & 4 & 41 \\
\hline Honorários do Contador & 1 & & 1 & 1 & 3 & & 8 & 2 & & & & & 3 & & 1 & & & & 1 & & 1 & & & & 2 & 24 \\
\hline $\begin{array}{l}\text { Contabilidade oficial feita } \\
\text { para o fisco }\end{array}$ & & 1 & & 1 & & & 1 & & & & 1 & & 1 & & & & 1 & & & & & & & & & 6 \\
\hline Adequação de relatório & & & & & & & 3 & & & & & & & 1 & & & & & 1 & & & & & & & 5 \\
\hline Ética & & & & & & & 3 & 2 & & & & & & & & & & & & & & & & & & 5 \\
\hline $\begin{array}{l}\text { Contabilidade Societária } \\
\text { feita por obrigatoriedade }\end{array}$ & & & & & & & 2 & & & 2 & & & & & & & & & & & & & & & & 4 \\
\hline $\begin{array}{l}\text { Conversão para padrão } \\
\text { internacional IFRS }\end{array}$ & & & 2 & & & & & & & & & & & & 1 & & & & & & 1 & & & & & 4 \\
\hline $\begin{array}{l}\text { Linguagem acessível, } \\
\text { tradução de termos e ajustes } \\
\text { de linguagem }\end{array}$ & 2 & & & & & & & & & & & & & & 1 & & & & & & & & & & & 3 \\
\hline $\begin{array}{l}\text { Relacionamento Contador - } \\
\text { PAPN }\end{array}$ & & & & & & & & & & & & & & & & & & 1 & & 2 & & & & & & 3 \\
\hline $\begin{array}{l}\text { Desinteresse do Contador na } \\
\text { MPE }\end{array}$ & & & & & & & & & & & & & & & & & & & & 1 & & & & & 1 & 2 \\
\hline $\begin{array}{l}\text { Informatização do governo } \\
\text { X Risco para Despachante }\end{array}$ & & & & & & & 2 & & & & & & & & & & & & & & & & & & & 2 \\
\hline Responsabilidade Civil & & & 1 & & & & & & & & & & & & & & & & & 1 & & & & & & 2 \\
\hline $\begin{array}{l}\text { Informatização do governo } \\
\text { X Sonegação }\end{array}$ & & & & & & & & 1 & & & & & & & & & & & & & & & & & & 1 \\
\hline $\begin{array}{l}\text { Pouca exposição ao usuário } \\
\text { externo }\end{array}$ & & & & & & & & & & & 1 & & & & & & & & & & & & & & & 1 \\
\hline $\begin{array}{l}\text { Usuário está dentro da } \\
\text { empresa, utiliza relatórios } \\
\text { próprios }\end{array}$ & & & & & & & & & & & 1 & & & & & & & & & & & & & & & 1 \\
\hline
\end{tabular}

Fonte: Elaborado pela Autora $(\mathrm{E}=$ Especialista e $\mathrm{P}=\mathrm{PAPN})$

Os serviços tradicionais oferecidos pelos escritórios contábeis dos contadores entrevistados, os Especialistas 7, 8 e 11, envolvem quatro áreas básicas: escrita contábil, escrita fiscal, departamento pessoal e paralegal (aberturas, encerramento e alterações):

A gente presta basicamente o serviço de terceirização do serviço de escrituração contábil, escrituração fiscal, a gente faz folha de pagamento das empresas dos nossos clientes e tudo o que envolve essa parte de legislação societária na constituição, na abertura de empresas, encerramento de empresas. (Especialista 11)

Três departamentos básicos: escrituração contábil, débito e crédito, propriamente dito, que geram os relatórios contábeis Balancete, Balanço, DRE, que ninguém pede; você atende a uma exigência legal, você tem que ter os livros diário e razão registrados se você quer distribuir os lucros para os sócios; você tem a escrita fiscal, 
o departamento fiscal, que faz a escrita fiscal, as compras, as vendas e as prestações de serviços, que gera a guia dos impostos retidos das vendas e serviços; e você tem o departamento pessoal que faz uma análise da folha em relação à convenção coletiva e uma rotina mensal, gera folha e fundo de garantia e todo mês, o que tiver de férias e rescisões para calcular. Basicamente são esses três serviços. (Especialista 7)

Eu estava pronta [para conduzir o próprio escritório] quando eu tinha esse mínimo possivel, eu sabia fechar uma folha de pagamento, eu sabia calcular todos os tributos, sabia mandar uma GFIP. (Especialista 8)

Na fala de quase todos os entrevistados foi evidenciado o peso das áreas fiscal e de folha de pagamento sobre os serviços oferecidos às MPEs. Para os PAPNs, o Contador é um intermediador entre a empresa e o governo, como sintetiza a PAPN 1:

Para mim, a questão da contabilidade estava relacionada ao quê? Quantas NF [notas fiscais] eu emiti, que imposto ia gerar em relação a isso, quantos funcionários eu tenho e que imposto vai ter em relação a esses funcionários, de FGTS, INSS e a minha relação com o sindicato, o que eu tenho que pagar para o sindicato. Basicamente eu achava que era isso.... A gente acaba se relacionando [empresária e contadora] é mesmo essa parte da relação da empresa com o governo. (PAPN 1)

A busca pelos serviços de um escritório contábil ou de um Contador pelo PAPN ocorre para formalização do negócio e apuração dos impostos e da folha de pagamento:

O micro e pequeno [empresário] precisa de uma porção de serviços, em relação à contabilidade. Eu tenho a impressão de que o micro e pequeno empresário, ele recorre ao contador para atender a finalidade fiscal, essa é a principal, eu acho. (Especialista 4)

A contabilidade brasileira, quando a gente fala desse nicho de pequenas [empresas] $e$ das microempresas, sempre foi uma contabilidade para atender fisco, para atender obrigações de legislação tributária, basicamente. (Especialista 3)

O contador ele é contratado para cumprir obrigações legais, sejam contábeis, sejam fiscais, o serviço vai ser subvalorizado. Para isso que se procura um contador. Nenhum empresário fala: "Eu vou procurar um contador porque eu quero me planejar para o futuro". Ele fala: "Vou contratar um contador porque ele precisa me 
[ajudar a] cumprir aqui essa obrigação legal, uma nova norma, que é obrigatória”. [Se] Aquilo vai ajudar, [ou se] não vai ajudar, não importa, tem que cumprir a norma. (Especialista 5)

Inclusive há clientes que querem apenas isso de seus contadores, como exemplificam as Especialistas 8 e 9:

Só que tem muito caso que o cara chega aqui, você mal vê a cara dele, você só manda os tributos para ele e ele acha que é essa a nossa função, entendeu? Muitas dessas pessoas chiam, porque acham que a nossa função é só essa, tem que apurar o tributo e mandar o tributo para eles. (Especialista 8)

Já os empresários que têm o seu negócio para sustento da família e querem manter-se no estágio em que já estão, ou seja, não almejam expansão ou novos empreendimentos, tendem a contentar-se com um serviço contábil destinado quase exclusivamente à apuração de impostos e fechamento de folha de pagamento. (Especialista 9)

A PAPN 1 indicou conversar com frequência com sua contadora sobre questões de contratação de funcionários e pagamentos de salários e encargos. A orientação sobre esses assuntos apareceu com recorrência na fala da Entrevistada. A PAPN 2 destacou que seu contador inicial lhe ajudou com a parte burocrática de constituição do negócio e com as emissões de guias de impostos, similar à PAPN 8 que acrescentou as informações físcais da empresa que impactam na sua declaração ao fisco como pessoa física. Já o PAPN 3, indicou receber relatórios de contabilidade financeira regularmente e a negociação com seu contador para implementar contabilidade gerencial.

O foco fiscal aparece também no discurso dos contabilistas. A Especialista 9 relatou ter percebido a insistência de um contador, com quem conversou durante sua pesquisa, de destacar a idoneidade tributária de seus clientes e seu escritório. Segunda a entrevistada, foi um pouco difícil sair do âmbito fiscal durante a entrevista com aquele profissional.

O termo 'Despachante de Impostos e Folha', empregado na codificação, reuniu falas que indicavam a visão de que o contador tem por função principalmente atividades relativas à escrita fiscal (apuração de impostos e entrega de declarações) e ao departamento pessoal (folha de pagamento, cálculo de férias, rescisões e encargos etc.) e a outros trabalhos de cunho burocrático: 
O contador quando entra com aquele papel da contabilidade tradicional, de preencher os formulários, de pagar imposto... porque a grande maioria dos contadores ainda tem a mentalidade do "preenchedor" de imposto. (Especialista 6) [ênfase adicionada]

Eu sinto que o contador hoje é um entregador de guias, um entregador de holerites, um entregador de impostos, o que eles querem? 'Eu quero uma guia, eu quero minha folha certinha e quero as guias do FGTS do INSS'. (Especialista 7) [ênfase adicionada]

Então o contador, todos esses anos, esses escritórios de contabilidade eles foram fazedores de guia, guias de recolhimento. Essa é a realidade no Brasil. (Especialista 3) [ênfase adicionada]

O Especialista 7 lembra que para fazer as atividades aqui tratadas como de 'despachante de impostos e folha de pagamento' não é necessária formação contábil, o trecho a seguir é parte do relato de uma situação em que um potencial cliente lhe fazia perguntas sobre as rotinas fiscais:

Ele queria, na verdade, saber como faz para ele tentar fazer e não pagar [impostos]. Ai eu fui embora. 'Ah, isso aí só contador. ' 'Por quê?? '. Não é, dá para ele fazer, se ele entrar no programa da Receita Federal e baixar o SICALC que faz os cálculos e souber os códigos e, também saber os códigos é aprender uma vez só e está disponível lá também: 'códigos da receita', ele sabe fazer. Acho que a folha é um pouquinho mais complicado, pelo INSS e fundo de garantia, você tem que entregar a SEFIP, mas se ele fizer cursos técnicos, rápidos, não precisa nem ser ele, o dono, treina a recepção, alguém lá, um administrativo que vai fazer, faz, não precisa ter CRC. (Especialista 7) [ênfase adicionada]

Em algumas passagens, foram feitas críticas à postura do contabilista quando muito focada nas questões de tributárias:

$O$ contador quando entra com aquele papel da contabilidade tradicional, de preencher os formulários, de pagar imposto, me parece que nesse momento, nesse contexto, é quase um inimigo do empresário, mais contribui para o empresário ficar com bronca da contabilidade do que gostar da contabilidade. (Especialista 6) 
Porque o contador é um mal necessário que a empresa tem. De qualquer maneira tem que ter alguém para assinar os livros... (Especialista 15)

Os contadores completamente 'outsiders', assim, do nosso negócio, sem saber direito o que a gente fazia, sem querer saber, emissores de guias, cada dia mais caros, sem dar a mínima orientação também. Um negócio bem mercantilista. (PAPN 2)

As atividades/informações do contador nessa atividade de intermediação escolagoverno são uma "caixa preta" para o empresário. A palavra burocracia representaria a função do contador nesse contexto. (PAPN 6)

Então acaba virando um fardo porque parece que é um cara que está ali só para assinar, para falar: 'O balanço da sua empresa é isso e eu preciso rubricar'. Não parece um cara que é parceiro seu, entendeu? (PAPN 8)

[ênfases adicionadas]

De acordo com o Especialista 6, o contador acaba sendo tratado como o "olho do governo" na empresa. Essa procura do profissional de contabilidade exclusivamente para assuntos de impostos e folha de pagamento é vista como algo desmotivador para o profissional, segundo o Especialista 7:

Eu gosto do que eu faço, eu acho bem... é que a contabilidade técnica vem me desmotivando, porque você que não tem nada além daquilo, ou perguntas: 'Você vai cobrar para fazer isso? Você entrega impostos, entrega holerites, entrega impostos, entrega holerites. (Especialista 7)

O excesso de obrigações acessórias impostas pelo Fisco seria uma das razões para que o Contador fosse associado às questões fiscais e de departamento pessoal:

Preencher obrigações que dão um monte de trabalho, que pega um monte de informação, às vezes, irrelevantes, às vezes, redundantes, porque você preenche isso em outras declarações repetitivamente, o que, ao meu ver, é justamente para ter mais multa para cobrar do contribuinte .... Você trabalha mais para o Fisco do que para empresa... (Especialista 8)

Se tivéssemos que fazer uma contabilidade gerencial dentro dos clientes nós não conseguiríamos atender tantos clientes. E a gente percebe também que nós também 
não conseguiríamos, no nosso foco, atender não só a empresa, mas cumprir as obrigações acessórias que a empresa tem em nome dela. Então a gente acaba priorizando esse tipo de coisa... (Especialista 11)

Atrelado a isso está o desconhecimento dos empresários sobre o que a contabilidade pode oferecer e a falta de interesse em conhecer:

Mas as coisas que ele me falava, as guias que ele emitia, os negócios de percentual, de imposto, disso e daquilo, para mim aquilo era um outro mundo com o qual eu não me importava muito, sabe? (PAPN 2)

Essa coisa de depender e a gente não saber direito o que consegue fazer sozinha e o que realmente o contador precisa fazer. Não está claro assim. Para mim, na verdade, acho que para a maioria das pessoas, não está muito claro o que o contador precisa fazer. (PAPN 8)

A procura por contabilidade gerencial não é comum entre os clientes dos escritórios dos Entrevistados. Há empresários que não conhecem esse braço da contabilidade, como o Especialista 13, ao relembrar da sua experiência empreendedora do passado, afirmou ter conhecido a área em um curso de pós-graduação, quando buscou seu contador. Porém, segundo ele, o profissional lhe deu "algumas dicas, sabia do que [Especialista 13] eu estava falando, mas não se mostrou parceiro, efetivamente disposto a ir além para me ajudar". $\mathrm{O}$ PAPN 3, que tem formação em administração, é um empresário que pediu contabilidade gerencial ao seu Contador e está em fase de implantação. Porém, o Especialista 11 expõe as dificuldades de oferecer esses serviços aos clientes dentro do escopo do Escritório Contábil por exigir atenção dedicada e, de preferência, dentro da empresa do cliente. Por isso, sugere que seja feita pelo próprio gestor:

Não, a gente não faz a gerencial para ele, a gente faz a contabilidade para escrituração de contabilidade por fora, a contabilidade societária. Esse é o nosso serviço, a gente não tem condições de fazer isso dentro da empresa, a gente até tem alguns clientes que a gente busca oferecer isso. Mas a consultoria, a gente até presta consultoria para esse fim, só que nós não temos condições de fazer a contabilidade gerencial, isso sendo um contador terceirizado. Eu percebo que não é muito difícil de fazer, teria de ter uma pessoa interna lá e o mais indicado seria o próprio gestor. 
Porque é, muitas vezes, o proprietário do negócio, seria a pessoa mais indicada para fazer esse controle, essa contabilidade gerencial. (Especialista 11)

Além das questões acima apresentadas, aspectos vinculados aos honorários do Escritório Contábil foram mencionados por mais da metade dos entrevistados e serão discutidos na sequência, juntamente com a percepção de qualidade dos serviços prestados pelos contabilistas.

\subsubsection{Honorários Contábeis e Percepção de Qualidade dos Serviços}

Os honorários pagos pelos serviços contábeis foi um dos assuntos mais citados pelos interlocutores. Tal valor é visto pelo PAPN como alto demais e insuficiente pelo Contador, resume o Especialista 13:

O contador não vê que tem uma relação custo-beneficio proveitosa para ele e o empresário acha que já está pagando muito para o contador. Ele não vai pagar mais para receber consultoria também. (Especialista 13)

De acordo com o Especialista 7, o valor da remuneração recebida pelo Escritório Contábil é desproporcional à responsabilidade assumida pelo contador, embora reconheça que não é pouco. Em suas palavras:

Eu acho que a gente assume muita responsabilidade e a remuneração proporcional não é a devida. Paga as contas de casa, tudo direitinho, mas se você me perguntar: 'Você está feliz com o que você ganha? '. [A resposta é:] 'Não'. Eu não acho que é pouco. Só acho que deveria ser mais pelo que eu assumo de responsabilidade. Por isso, que eu vou atrás de consultoria. (Especialista 7)

O honorário mensal tem seu peso amplificado quando a pequena empresa está passando por dificuldades, como é o caso da PAPN 2, a qual não conta com contador atualmente, e em fase inicial e se firmando no mercado, como é o caso da empresa de arquitetura da PAPN 8. Ela expõe:

Você tem que pagar um salário mínimo. Eu consegui fazer como que eu pagasse meio salário mínimo porque ia ficar pesadíssimo para mim pagar um salário mínimo .... Eu não consigo pagar um salário mínimo mais décimo terceiro dele, mais não sei o quê. Então, assim, não fica viável.... Ele [Contador] falou: “Ah, mas se você mudar para uma empresa de arquitetura, eu vou ter que cobrar de você um salário mínimo. ” E eu falei: “Nossa, mas você está vendo meus ganhos. ” Eu não consigo pagar um salário 
mínimo mais décimo terceiro dele, mais não sei o quê. Então, assim, não fica viável. (PAPN 8)

A PAPN 8 afirma que o valor do honorário mensal é fator para escolha do contador:

Acho que essa é a visão, tanto é que a conversa entre arquitetos, empresários é assim 'Pô, você conseguiu um contador? Qual? Meu contador só cobra 250 por mês que é para fazer só nota. ' Então você vai muito pelo preço, não vai muito pelo o que ele te oferece. Parece que é uma coisa, tipo um fardo que você tem que carregar. É uma coisa ruim demais para os dois lados, né? (PAPN 8)

O Especialista 7 mostrou seu incômodo quando o cliente questiona se os seus aconselhamentos terão custo adicional:

Quando você passa lá e fala: 'Olha, vamos marcar um dia para eu te mostrar que você está indo num erro, que você está faturando mais no cartão do que em notas e isso vai te dar problemas? '. [E ele pergunta: ]'Mas você cobra por isso? '. [E eu respondo: ] 'Não, eu vou aí te explicar, é assessoria mesmo. 'Então isso assim vem me desmotivando. (Especialista 7)

Para a Especialista 1, falta ao Contador explicar o que está por trás dos honorários: "Contador cobra honorário, mas não explica, não ajuda, não conversa".

Os baixos valores recebidos pelos escritórios contábeis dos PAPNs, conforme os Especialistas 5 e 7, inviabilizariam a atenção mais proativa por parte dos contadores, como sintetiza o Especialista 5:

Vou fazer um chute, por duzentos reais mensais não tem como o escritório fazer milagre também, dele pegar vir puxar a orelha, dizer não você tem que vir aqui. Então a relação comercial do escritório de contabilidade com o cliente é complicada. (Especialista 5)

De acordo com o Especialista 7, o aumento do imposto recolhido é motivo de descontentamento com o contador, o qual tem a qualidade do seu serviço avaliada por alguns PAPNs dependendo do quão menor é o imposto que será pago pela empresa, independente da forma como isso seja feito: 
Se você pega o microempresário, você é avaliado como contador, essa é a visão que eu tenho, de que maneira você consegue fazer ele [o microempresário] pagar menos impostos, sonegando ou não. Se você conseguir fazer ele pagar menos imposto que outro contador, mesmo que para isso você recorra à evasão fiscal, então você é melhor que o outro. (Especialista 7)

Em consonância com tal experiência, a Especialista 1 expõe a desconfiança do empresário quando o aumento acontece:

A gente ouvia do pequeno empresário que ia lá no SEBRAE reclamar do contador, [que] ele não vê o contador como parceiro, ele desconfia. Por exemplo, se ele paga mais impostos, ele acha que o contador está roubando ele. Ele não tem essa consciência de que o contador é parceiro. Essa consciência, infelizmente, não existe. (Especialista 1)

O volume de obrigações acessórias que o Contador é obrigado a produzir para empresa, bem como a complexidade das normas, que são alteradas constantemente, obriga o profissional a investir em capacitação. Porém, quando uma nova obrigação é criada pelo Fisco, o PAPN-cliente não aceita aumentar o valor do honorário e o Escritório Contábil absorve mais um custo:

Você explica para o teu cliente "Olha eu vou ter mais trabalho então eu vou cobrar mais honorários. "O cliente reclama: "Não, porque eu não posso pagar." [E você explica:] "Mas o Fisco colocou isso. Você vai ter que declarar mais. " [E ele responde:] "Mas eu não quero pagar mais. ” (Especialista 8)

Quando consulta o contador: "Ah eu vou mudar do lucro presumido para o lucro real." [E ele responde:] “Bom, isso te custa mais”... Ele [o empresário] não quer pagar porque ele não está vendo aquilo como um benefício para ele, ele está vendo como mero cumprimento da legislação. (PAPN 5)

Para a Especialista 8, o PAPN-cliente teria razão. Afinal, o Contador está trabalhando para o fisco e "qual retorno que o fisco te dá? Ele reduz seu tributo? Não. Ele dá algum reconhecimento para o contador? Não. ” A Especialista conclui: "você trabalha mais para o Fisco do que para o cliente!" 
Porém, existem PAPNs que aceitam renegociar o honorário em favor do escritório contábil. Dentre os empresários consultados, o PAPN 3, com perfil empreendedor e negócio em crescimento, explicitou a situação na qual o contador não conseguia segregar informações por centro de custo na forma como o empresário desejava. Ele mesmo sugeriu revisão de honorário:

Ele não consegue, não por má vontade, mas por uma limitação talvez do sistema que ele usa, que é o [nome do software usado pelo escritório]. [contador: ] 'Ah, não faz, só tem uma divisão por centro de custo, do jeito que você quer, você tem não sei quantos funcionários, a gente ia ter que criar um novo de centro de custo, ia dar uma trabalheira danada. ' [PAPN 3: ] 'Ok, uma coisa é dar trabalho, você pode falar comigo e eu pago mais, mas dá para fazer, então?' A gente está nesse ponto. (PAPN 3)

A Especialista 8 afirma que também há os clientes que assentem o aumento em função da relação de confiança com o contador e esse comportamento representa um reconhecimento do trabalho do profissional:

Bom, primeiro pela assiduidade. Porque, geralmente, assim, você vai negociar aumento de honorários. Por exemplo, é um dos níveis que você vê ali o cara: "Ah, não você está cobrando muito caro, vou procurar outro contador. " Mas tem gente que fala: "Não, tudo bem, vou pagar, confio no teu trabalho. ” (Especialista 8)

O envio regular de relatórios contábeis com a correspondente conversa sobre os números poderia aumentar a percepção de valor dos PAPNs que poderiam acatar renegociações de honorários com mais facilidade. E é o que sugere o Especialista 7. Além disso, esse profissional também sugere que, sem a escrita contábil, conseguiria reduzir seus honorários:

Se eu não tivesse que fazer a escrita contábil dos meus clientes, eu conseguiria reduzir meus honorários para metade, porque a escrituração contábil é a que mais demanda mão de obra. (Especialista 7)

Porém, o envio regular dos relatórios contábeis não é solicitado por todos os clientes. Ainda na visão do Especialista 7, existiria por ambas as partes, Contabilistas e PAPNs, uma percepção de que os honorários não seriam suficientes para o oferecimento de serviços 
contábeis mais completos. O Especialista 7 chama isso de círculo da mediocridade. Em suas palavras:

Eu acho que é um círculo, um círculo vicioso que eu chamo de círculo da mediocridade. Mediocridade não no sentido pejorativo, mas no sentido de ser mediano mesmo. Ou seja, ele me paga por um serviço mediano, eu vou prestar um serviço mediano, cobrando um preço mediano e fica todo mundo fica contente com o mediocre. Então, se o cliente me pedisse relatório todo mês, provavelmente eu teria que ter algum tempo ou disponibilizar algum funcionário para ir explicar esses relatórios mensais. Eu acho que em algum momento eu iria conversar sobre preços. (Especialista 7)

Ele também acredita que o regime tributário simplificado, o Simples, permitiria "reduzir uns 20, 30\% o valor do honorário", redução que poderia ser ainda maior no caso de grandes escritórios contábeis. Essa facilidade nas rotinas acessórias atreladas a esse regime tributário acaba levando alguns profissionais da área a induzir seu cliente ao enquadramento, situação cujo relato já foi aqui referenciado na fala do Especialista 5 e foi vivida pela PAPN 8:

De novo eu tenho essa vontade de virar uma empresa de arquitetura, porque se você vende decoração e você pega um cliente pessoa jurídica, você vai fazer um projeto de interiores, você passa por aquela saia justa, que é uma coisa com que não concordo. 'Tudo bem, mas minha nota é de serviço de decoração. ” Sabe? Poxa, né? (PAPN8)

A empresária relatou ter insistido em conversar com seu Contador sobre o enquadramento fiscal de seu negócio. Porém, o profissional insistia que não seria viável: "Então você me dá um demonstrativo, me ajuda nisso para eu decidir se vale a pena ou não. E ele disse: 'Não vai dar certo isso, você não vai pagar menos impostos. '” (PAPN8).

Além dessas questões, o Escritório Contábil esbarra em dificuldades e demandas de mercado similares àquelas enfrentadas por grande parte de seus clientes. Afinal, a grande maioria também é uma MPE. As questões sobre as especificidades da gestão do Escritório Contábil são apresentadas no tópico seguinte. 


\subsubsection{A gestão do Escritório Contábil}

As dificuldades para conseguir ampliar a carteira de clientes e expandir a infraestrutura e a capacidade de atendimento, os honorários baixos frente ao volume de trabalho demandado por cliente, especialmente no âmbito de prestação de contas ao Fisco, a constante necessidade de investimento em treinamento, dada a complexidade da legislação e suas constantes alterações, os riscos envolvidos na atividade, e as demais dificuldades comuns ao processo de gestão de uma MPE, que foram apresentadas anteriormente, compõem a dinâmica de gestão do Escritório Contábil, apreendida dos relatos dos entrevistados.

Sobre a captação de clientes, o Especialista 12 acredita que "a maior dificuldade seria ter uma maneira de relacionamentos que faça com que você chegue até determinada empresa". A indicação de clientes foi apontada como a principal forma de conquista de novos clientes:

A gente percebia que tinha uma certa dificuldade de chegar e começar os trabalhos, sempre era necessária a indicação de alguém ... (Especialista 12)

A maioria dos clientes que eu tenho aqui é tudo indicação. Não é [por causa do] ponto [localização do escritório] porque é um lugar lá... o escritório é pequeno, não é grande, ele é fora de mão, aqui não é chique, ele é afastado ..., mas eu tenho muita procura justamente em função de indicação, isso é bem gratificante. (Especialista 8)

Para o PAPN 5, a dificuldade de captar clientes teria origem na formação do Contador, a qual o prepararia tecnicamente, mas não o prepararia para vender os serviços contábeis e seus correspondentes benefícios. Nas palavras dele:

Mas, talvez ainda falte não só essa questão do conhecimento técnico, falte... acho que o contador entender melhor o negócio dele e seus benefícios. Às vezes, isso não é ensinado nas universidades. Ele está preparado para cumprir as obrigações, [mas] ele não está preparado para demonstrar o quanto o serviço dele é importante. Então acho que falta [esse preparo] e isso pode ser uma variável importante para evolução nesse quesito.... Isso para mim é muito claro que o contador não está preparado pelo menos para saber vender o serviço dele. (PAPN 5)

Como profissão regulamentada, o Contabilista está submetido a normas e tem responsabilidade solidária em diversos âmbitos com relação ao cliente. Essa realidade é fator de ponderação na manutenção da clientela, como expõem os Especialistas 8 e 11 que optaram 
por dispensar clientes quando esses mantêm práticas que representam riscos ao Escritório Contábil. Segundo eles:

Em algumas poucas situações eu perdi cliente dessa maneira [inciativa própria de romper contrato], porque a gente também não tem que baixar a bola. Você não tem que reverenciar o cliente. Você tem que se colocar numa posição que... eu sou um profissional, eu não tenho que me submeter. Não sou uma prostituta. Eu estou precisando? Estou. Mas não a ponto de eu ter que pegar e rasgar o meu diploma numa cilada. (Especialista 8)

No nosso escritório, nos últimos dois anos, a gente dispensou alguns clientes porque as práticas evasivas eram muito arriscadas para nós. A gente decidiu não atender esse tipo de empresa por causa desse tipo de comportamento, a gente prefere preservar a nossa integridade no negócio. (Especialista 11)

Algumas práticas de gestão não são observadas pelos Contadores, quando esses estão na posição de proprietários administradores de seus negócios. O Especialista 7 compartilhou usar práticas um pouco intuitivas na formação de preço do seu honorário. A Especialista 8 mantém o formato de contratação e cobrança estabelecido pelo Contador proprietário anterior do escritório e de quem arrendou a carteira de clientes. Porém, no seu período de gestão, detectou que o formato, o qual incluiu consultoria e os serviços tradicionais em um mesmo honorário mensal, não é viável. Até o momento da entrevista, a empresária estava pensando sobre a revisão do modelo contratual para os seus novos clientes.

Nos três Escritórios Contábeis dos Especialistas entrevistados, havia um componente familiar. Os Especialistas 7 e 11 mantêm escritórios originados na família, enquanto a Especialista 8 trouxe seus irmãos para encabeçar áreas centrais do seu escritório. No âmbito da gestão de colaboradores não familiares, foi citado pelo Especialista 7 o impasse entre o modelo de alto salário e profissional qualificado que deixa o escritório para abrir o próprio negócio, versus o baixo salário e organização interna para lidar com a alta rotatividade. Já a Especialista 8 afirma investir na valorização do profissional e no incentivo à sua capacitação. Seu dilema, como expôs, é precisar e querer contratar mais funcionários, mas não ter condições de pagar o salário ideal de um profissional qualificado.

No âmbito comercial, o PAPN 5 chamou a atenção para a importância de se mostrar ao cliente do escritório contábil os benefícios atrelados aos serviços contratados. Essa 
necessidade ficou evidenciada na fala da PAPN 4 ao relatar sua prospecção de um contador: "Ele se ofereceu a ser contador de MEI por $R \$ 150$ por mês para não fazer nada em específico. Não disse quais serviços ele ia fazer para cobrar esse valor e nem porque ele era necessário para isso."

Na visão do PAPN5 e da Especialista 10, o Contador não é preparado para vender ou negociar seu serviço. Porém, contrariando essa visão, o PAPN 3, que enxerga a terceirização da contabilidade como uma estratégia de redução de custos, vê seu Contador como "comercialmente habilidoso". Em suas palavras:

[O Escritório Contábil] tem pacotes que são vendidos a valor fixo mensal e tem pacotes que são pagos por uso. Comercialmente ele é muito habilidoso, o pessoal lá da contabilidade, é muito conveniente trabalhar com eles. (PAPN 3)

A dificuldade de equacionar número de clientes e visitas do Contador foi abordada pelo Especialista 7, quem tenta manter uma rotina de visitas aos seus clientes.

A ética e a relação de confiança apareceram nas falas dos Especialistas 7 e 8 . O primeiro, tratou do relacionamento com seus colaboradores que precisa ser de confiança, pois, não é possível que ele controle e revise todos os trabalhos realizados. A segunda, a Especialista 8, tratou da ética no âmbito do relacionamento com o cliente, quem ficaria "nas mãos" do Contador por não entender de determinados assuntos. Disse ela:

Tem muito cliente que não entende, a maioria deles não entende de contabilidade. Então, eles estão na tua mão. O cliente está na tua mão! Se você errar um tributo e o teu cliente não souber, não entender, [e] você quiser agir de má fé, você age. Mas eticamente você não age dessa maneira. Mas tem muito contador que age e, eu acho assim, que você tem que oferecer o teu know-how de trabalho, o material humano. Você trabalha com o teu intelecto e é isso que você tem que oferecer. (Especialista 8)

A segmentação ou especialização do Escritório Contábil é apontada pelo Especialista 3 como diferencial competitivo. Segundo ele:

Você tem sim que ter o domínio da metodologia [contábil]. Mas eu acho que tem que ir além, ter uma visão de negócio, se especializar num segmento, se especializar num negócio. Eu acho que o generalista perde. Cada vez mais você se especializa num 
segmento, mesmo numa micro[empresa], você tem segmentos: 'Pô, eu só atendo farmácias. Eu só atendo padarias. Eu só atendo lojas no varejo’. (Especialista 3)

Esse modelo de atuação também apareceu na fala de outros Especialistas, como o Especialista 5, que afirmou não ser qualquer Escritório Contábil capaz de atender as Empresas de Base Tecnológicas e como o Especialista 7 que se concentrou no nicho da veterinária, sua primeira formação, sendo visto por seus clientes como alguém que fala a língua deles.

\subsubsection{A Formação do Contador e seus reflexos na rotina de atendimento de MPEs}

O Ensino da Contabilidade foi citado por nove interlocutores, recebendo 27 nós, conforme indicado na Tabela 13 a seguir:

Tabela 13: Subcategorias e nós associados ao Ensino de Contabilidade

\begin{tabular}{|c|c|c|c|c|c|c|c|c|c|c|c|c|c|c|c|c|c|c|c|c|c|c|c|c|c|c|}
\hline $\begin{array}{l}\text { Categoria e } \\
\text { Subcategoria }\end{array}$ & $\begin{array}{l}\mathbf{E} \\
\mathbf{1}\end{array}$ & $\begin{array}{l}\mathbf{E} \\
2\end{array}$ & $\begin{array}{l}\mathbf{E} \\
\mathbf{3}\end{array}$ & $\begin{array}{l}E \\
4\end{array}$ & $\begin{array}{l}\mathbf{E} \\
5\end{array}$ & $\begin{array}{l}E \\
6\end{array}$ & $\begin{array}{l}E \\
7\end{array}$ & $\begin{array}{l}\mathbf{E} \\
8\end{array}$ & $\begin{array}{l}\mathbf{E} \\
\mathbf{9}\end{array}$ & $\begin{array}{l}E \\
10\end{array}$ & $\begin{array}{c}E \\
11\end{array}$ & $\begin{array}{c}E \\
12\end{array}$ & $\begin{array}{c}E \\
13\end{array}$ & $\begin{array}{l}E \\
14\end{array}$ & $\begin{array}{l}E \\
15\end{array}$ & $\begin{array}{l}E \\
16\end{array}$ & $\begin{array}{l}\mathbf{P} \\
1\end{array}$ & $\begin{array}{l}\mathbf{P} \\
2\end{array}$ & $\begin{array}{l}\mathbf{P} \\
\mathbf{3}\end{array}$ & $\begin{array}{l}P \\
4\end{array}$ & $\begin{array}{l}\mathbf{P} \\
5\end{array}$ & & & & 8 & $\sum$ \\
\hline $\begin{array}{l}\text { Ensino de } \\
\text { Contabilidade } \\
\end{array}$ & 3 & & 3 & & & & 5 & 1 & & 7 & 1 & & 1 & & & & & & & 1 & 5 & & & & & 27 \\
\hline $\begin{array}{l}\text { Formação do } \\
\text { Contador }\end{array}$ & 2 & & 1 & & & & 5 & 1 & & 3 & 1 & & & & & & & & & & 5 & & & & & 18 \\
\hline $\begin{array}{l}\text { Papel da } \\
\text { Universidade }\end{array}$ & 1 & & 2 & & & & & & & 4 & & & 1 & & & & & & & 1 & & & & & & 9 \\
\hline
\end{tabular}

Fonte: Elaborado pela Autora (E = Especialista e P $=$ PAPN)

Os Especialistas com formação em Contabilidade criticaram aspectos do ensino superior da área no que tange o preparo para lidar com as MPEs, especialmente os que atuam em Escritórios Contábeis, segundo os quais, o conhecimento necessário para atuar nos serviços mais demandados pelos PAPNs, rotinas fiscais e de departamento pessoal, foi adquirido fora da graduação em cursos e treinamentos adicionais ou na prática, como coloca o Especialista 7:

E meu pai [ Contabilista, dono do escritório matriz do Especialista 7] sempre falava isso: " A faculdade não vai te dar nada. Toda a teoria da faculdade você não vai aplicar aqui. Aqui é uma outra realidade". E eu posso dizer que a minha experiência aqui na [nome da faculdade], na graduação, eu realmente não aprendi nada disso: serviço técnico[ escrita fiscal e folha de pagamento]. (Especialista 7)

Para a Especialista 1, o Contador que apoia os PAPNs, precisa ter habilidades administrativas, conhecer de administração. Segundo ela, as universidades deveriam oferecer preparo diferenciado, direcionado à realidade dos pequenos negócios, afirma ela:

Enquanto a universidade não formar professores ou alunos, futuros profissionais, voltados com uma preocupação específica para a pequena empresa, com realidades 
totalmente diferenciadas, numa linguagem acessivel a eles. Você sabe que a linguagem que a gente utiliza hoje na contabilidade ela não é acessível nem para quem é grande empresário, imagina para os pequenos empresários. (Especialista 1)

Também foram mencionadas a falta de preparo do Contador para vender e negociar seus serviços, como afirmaram a Especialista 10 e o PAPN 5.

O papel da universidade em relação às MPEs é destacado pela Especialista 10 ao compartilhar as experiências de extensão em que a universidade, por meio dos alunos e sob orientação dos professores, levava o conhecimento acadêmico para os PAPNs. De acordo com o Especialista 3, cabe à universidade estimular o empreendedorismo em seus alunos, acompanhar as mudanças de mercado e ensinar e disseminar a nova contabilidade, ou seja, aquelas convergidas para o padrão internacional.

\subsection{Aspectos associados ao Ambiente Tributário e à Burocracia}

A subcategoria 'carga tributária e a sonegação de impostos' foi a que recebeu o maior número de nós dentro da categoria Tributos e Burocracia. A discussão sobre esses dados será apresentada na sequência e está sintetizada na Tabela 14:

Tabela 14: Subcategorias e nós associados a Tributos e Burocracia

\begin{tabular}{|c|c|c|c|c|c|c|c|c|c|c|c|c|c|c|c|c|c|c|c|c|c|c|c|c|c|}
\hline $\begin{array}{l}\text { Categoria e } \\
\text { Subcategoria }\end{array}$ & $\begin{array}{l}\mathbf{E} \\
1\end{array}$ & $\begin{array}{l}\mathbf{E} \\
2\end{array}$ & $\begin{array}{l}\mathbf{E} \\
\mathbf{3}\end{array}$ & $\begin{array}{l}E \\
4\end{array}$ & $\begin{array}{l}\mathbf{E} \\
\mathbf{5}\end{array}$ & $\begin{array}{l}E \\
6\end{array}$ & $\begin{array}{l}\mathbf{E} \\
7\end{array}$ & $\begin{array}{l}\mathbf{E} \\
8\end{array}$ & $\begin{array}{l}\mathbf{E} \\
9\end{array}$ & $\begin{array}{l}\mathbf{E} \\
\mathbf{1 0}\end{array}$ & $\begin{array}{c}E \\
11\end{array}$ & $\begin{array}{c}\mathbf{E} \\
12\end{array}$ & $\begin{array}{c}E \\
13\end{array}$ & $\begin{array}{c}E \\
14\end{array}$ & $\begin{array}{l}E \\
15\end{array}$ & $\begin{array}{l}E \\
16\end{array}$ & $\begin{array}{l}\mathbf{P} \\
1\end{array}$ & $\begin{array}{l}\mathbf{P} \\
\mathbf{2}\end{array}$ & $\begin{array}{l}\mathbf{P} \\
\mathbf{3}\end{array}$ & $\begin{array}{l}\mathbf{P} \\
4\end{array}$ & $\begin{array}{l}\mathbf{P} \\
5\end{array}$ & $\begin{array}{l}\mathbf{P} \\
6\end{array}$ & $\begin{array}{l}\mathbf{P} \\
7\end{array}$ & $\begin{array}{l}\mathbf{P} \\
8\end{array}$ & $\sum$ \\
\hline Tributos e Burocracia & & & 3 & & & 3 & 7 & 6 & & 2 & 4 & & & & & & & & & & & 1 & & 4 & 30 \\
\hline $\begin{array}{l}\text { Carga Tributária e } \\
\text { Sonegação }\end{array}$ & & & 1 & & & 3 & 6 & 3 & & 2 & 3 & & & & & & & & & & & & & 2 & 20 \\
\hline $\begin{array}{l}\text { Complexidade das normas e } \\
\text { burocracia }\end{array}$ & & & 2 & & & & & 3 & & & 1 & & & & & & & & & & & 1 & & 1 & 8 \\
\hline $\begin{array}{l}\text { Informatização do governo } \\
\text { X Sonegação }\end{array}$ & & & & & & & 1 & & & & & & & & & & & & & & & & & & 1 \\
\hline $\begin{array}{l}\text { Regime tributário } \\
\text { simplificado }\end{array}$ & & & & & & & & & & & & & & & & & & & & & & & & 1 & 1 \\
\hline
\end{tabular}

Fonte: Elaborado pela Autora $(\mathrm{E}=$ Especialista e $\mathrm{P}=\mathrm{PAPN})$

A carga tributária e a sonegação receberam a mesma subcategoria porque, de acordo com as falas dos Especialistas, esses temas andam frequentemente ligados quando se trata da MPE. O Especialista 6 afirmar ser algo cultural:

Uma coisa que na época não, mas hoje eu vejo, hoje eu chamaria de problema mesmo. Hoje. Eu não tinha bem essa consciência, é o fato, por exemplo, no que se refere a tributos. O empresário do micro ou pequeno negócio sempre querendo 
sonegar, querendo levar vantagem com relação ao Fisco, sabe? Isso é bem cultural, típico. Aliás, eu não sei se isso é só do pequeno e médio, não é? [risos] Mas, enfim, muitos deles acreditam fortemente que para ter sucesso, para a empresa progredir, não pode pagar muito imposto, que tem que sonegar o máximo possível... Sabe esse negócio? De não querer pagar imposto, de vender sem nota, funcionário sem registro. Mas isso é como se fosse para sobreviver. Na cabeça deles, precisa daquilo para sobreviver. Então eu vejo isso como um problema mesmo. Hoje, eu estou convencido de que eles estão errados. De repente, isso pode até ser um fator para eles não irem para frente. (Especialista 6 )

O Especialista 7 nota que alguns PAPNs quando criticam a alta carga tributária, fazem isso subjetivamente, com base em cálculos intuitivos, muitas vezes superestimados e incompatíveis com a realidade de seus negócios, os quais estão enquadrados em regime simplificado de tributação, o Simples. Para a Especialista 8, existe uma ideia entre os PAPNs de que o Simples implica em menor fiscalização. Portanto, é o melhor regime em qualquer situação. E, por isso, teriam que esforçar-se para manter o faturamento dentro do limite permitido ao regime, o que ela discorda:

[No SIMPLES] você tem alíquotas menores até, entre aspas, porque se você fizer um planejamento tributário, às vezes, muitas empresas estão pagando mais tributo do que pagariam no lucro real. Mas eles têm medo, têm na cabeça que o SIMPLES é melhor, eles são menos fiscalizados e punidos também por conta disso. Mas eles querem se limitar e ficar faturando até 3 milhões e 600 mil para não pagar mais imposto. (Especialista 8)

A omissão de receita, ou seja, a venda informal sem emissão de nota fiscal é o principal fator para que o empresário oculte informações do Contador, afirma o Especialista 11. Essas operações informais fazem com que a contabilidade oficial, preparada pelo Contador, seja diferente daquela que o empresário tem internamente, como argumenta o Especialista 3.

Contrariando a ideia da necessidade de sonegar para sobreviver, colocada pelo Especialista 6, o Especialista 7 ressalta que seus clientes que recolhem os tributos sobre todas as receitas têm conseguido se manterem no mercado: 
Eu tento colocar eles na linha. Alguns deles fazem algum comentário: "Nunca paguei tanto imposto como depois que você entrou. " E eu não vejo isso como uma crítica. É uma crítica, mas eu não vejo como crítica. Eu falo "Bem-vindo ao Brasil, no nosso país é assim”. Mas a maioria tem conseguido pagar os impostos e ficar no mínimo positivo, senão teriam fechado. (Especialista 7)

O peso da carga tributária é ainda mais sentido para negócios em fase inicial, de acordo com a PAPN 8:

Porque realmente é forte, você está começando o negócio que você tem que pagar $17 \%$ de tudo o que você, mais o contador que é um salário mínimo, mais décimo terceiro, mais o sindicato, mais o seu CAU [registro profissional] que é do conselho, mais o conselho da empresa, um escritório de arquitetura que está começando não consegue sustentar tudo isso, entendeu? É muita coisa. Eu acho muito doido isso de cobrar tanto imposto para empresas que estão iniciando. (PAPN 8)

A PAPN 8 defende a existência de uma graduação na tributação pela idade do negócio. Ou seja, empresas nascentes pagariam menos impostos, os quais aumentariam de acordo com o crescimento. Sugestão similar também é defendida pela Especialista 8, a qual enxerga que a diferença no volume de impostos, obrigações acessórias e exigências entre o regime simplificado, o Simples, e os demais regimes tributários, Presumido e Real, como um dos motivadores para que os empresários tentassem artimanhas diversas para manter-se no Simples. Ela exemplificou a situação de clientes que segregam o negócio formalmente em várias empresas para continuar enquadrado no regime simplificado, com cada negócio faturando o teto permitido.

A sonegação e artimanhas evasivas são um empecilho para a assessoria contábil de qualidade. De acordo com a Especialista 10, “eu não vou ter uma assessoria verdadeira se eu não passar informações verdadeiras e se eu passo informações verdadeiras, eu vou mostrar que sou diferente daquilo que eu aparento ser". Além de atrapalhar a qualidade do serviço contábil, essas práticas representam risco aos escritórios de contabilidade e ao contador, como relato o Especialista 7:

Mas nessa questão de sonegação eu tento passar isso até porque a responsabilidade do contador é muito grande. Então hoje nós somos responsáveis solidários por 
metade da falcatrua que esse cliente faz. Então eu quero diminuir esse meu passivo, esse meu risco. (Especialista 7)

O excesso de obrigações acessórias, de prestação de contas ao Fisco e de burocracia é outro tema recorrente quando o assunto é tributação e prejudica tanto o empresário, quanto o profissional da área contábil. Para o empresariado, mesmo estando a MPE em regime tributário simplificado, a complexidade das normas é alta. Na visão do Especialista 3:

A realidade brasileira ainda é uma realidade voltada para atender a legislação tributária. E, nós sabemos que, dada a complexidade tributária brasileira, que é uma complexidade realmente cruel para os empresários, mesmo falando do Simples. (Especialista 3)

Tal complexidade é evidenciada no relato do PAPN 6:

O que atrapalha o negócio não é a carga tributária em si. A questão não é que ela é alta, mas sim confusa. Por mais que você se empenhe em ter tudo certo, é difícil ter segurança de que está tudo bem, pois as leis são complexas e pouco claras. (PAPN 6)

Um exemplo de excesso de burocracia foi relatado pela PAPN 8 em sua saga para alterar o endereço de sua empresa, frente ao custo do serviço cobrado pelo Contador e suas dificuldades de caixa. Para ela, algo assim deveria ser simples, podendo ser feito pelo próprio empresário. Ela conta sua dificuldade:

Primeiro existe uma super burocracia eu acho. Vou dar um exemplo bobo, a minha empresa foi aberta em um endereço no apartamento que eu morava em Moema. Até hoje eu não mudei esse endereço porque eu me mudei para o Butantã e fiquei no corre-corre. E não consegui porque é o contador que tem que mudar isso. E aí ele cobra mil reais só para mudar o endereço da empresa, porque ele falou que é supercomplicado. Eu acho que deveria ser uma coisa que eu poderia fazer, entendeu? Preciso dele para eu mudar o endereço? Aí quando eu estava quase juntando a grana, 'beleza, vamos mudar o endereço', ai eu saí do Butantã e agora eu estou aqui. Meu contrato vence em março do ano que vem. Então, eu estou com o endereço da empresa de uma coisa que eu alugava três anos atrás. É muito chato porque chega uma carta da minha empresa lá a dona do apartamento vai falar assim: 'Que que está chegando uma carta de uma empresa no meu endereço?' Isso pode me trazer problemas até. A gente tem que ter uma grana para fazer essa mudança de endereço 
que deveria ser uma coisa simples que eu, pela internet, poderia fazer. Talvez seja e eu que não sei. Porque parece que faz tudo ficar complicado. (PAPN 8)

$\mathrm{Na}$ perspectiva dos profissionais contábeis, a burocracia e excesso de obrigações acessórias ao Fisco tomam o tempo do Contador e representam risco ao escritório, visto que erros são custosos. O Especialista 11 afirma: "Eu percebo que um dos grandes problemas é a questão de cumprimento de obrigações, lado bastante burocrático". A Especialista 8 critica o excesso de obrigações acessórias, muitas vezes redundantes. Para ela, o tempo gasto com essas redundâncias poderia ser direcionado a atenção ao cliente, quem realmente paga pelos seus serviços. A Especialista 8 defende, ainda, uma obrigação acessória unificada para simplificar a rotina e liberar tempo ao Contador. Em suas palavras:

Teria que ter uma obrigação unificada, quando a gente manda o SPED contábil [escrituração contábil digital] tem tudo que eles precisam saber ali, já tem a DIMOF [declaração das operações financeiras que os bancos enviam à Receita Federal] que é uma comanda de crédito que o banco manda. Então, não precisa de mais nada, não precisa ficar... E fora mais tempo para gente, contador, poder oferecer um serviço melhor para o nosso cliente, que é o nosso papel e não trabalhar para o Fisco.... Se simplificar, a gente vai conseguir, de repente, ter mais tempo para oferecer um serviço melhor. (Especialista 8)

Como apontado pelos interlocutores, cujas percepções foram acima resgatadas, a carga tributária é tema que faz parte da vida da MPE e é muitas vezes associada à necessidade de sonegação para existência do negócio. Essa postura associada à complexidade da legislação e o excesso de obrigações acessórias e burocracias exigidos pelo fisco dificultam a vida do PAPN e do Contador.

\subsection{Aspectos associados à Comunicação}

A comunicação permeia indiretamente todas as situações relatadas pelos Entrevistados e diretamente em 20 situações que foram associadas às subcategorias demonstradas na Tabela 15: 
Tabela 15: Subcategorias e nós associados à Comunicação

\begin{tabular}{|c|c|c|c|c|c|c|c|c|c|c|c|c|c|c|c|c|c|c|c|c|c|c|c|c|c|}
\hline Categoria e Subcategoria & $\begin{array}{l}\mathbf{E} \\
1\end{array}$ & $\begin{array}{l}\mathbf{E} \\
\mathbf{2}\end{array}$ & \begin{tabular}{|l}
$\mathbf{E}$ \\
$\mathbf{3}$
\end{tabular} & $\begin{array}{l}E \\
4\end{array}$ & $\begin{array}{l}\mathbf{E} \\
\mathbf{5}\end{array}$ & $\begin{array}{l}E \\
6\end{array}$ & $\begin{array}{l}\text { E } \\
7\end{array}$ & $\begin{array}{l}E \\
8\end{array}$ & $\begin{array}{l}\text { E } \\
9\end{array}$ & $\begin{array}{c}E \\
10\end{array}$ & $\begin{array}{c}E \\
11\end{array}$ & \begin{tabular}{|c}
$\mathrm{E}$ \\
12
\end{tabular} & $\begin{array}{c}E \\
13\end{array}$ & $\begin{array}{c}\mathrm{E} \\
14\end{array}$ & $\begin{array}{c}E \\
15\end{array}$ & $\begin{array}{c}\mathrm{E} \\
16\end{array}$ & $\begin{array}{l}\mathbf{P} \\
1\end{array}$ & $\begin{array}{l}\mathbf{P} \\
\mathbf{2}\end{array}$ & $\begin{array}{l}\mathbf{P} \\
3\end{array}$ & $\begin{array}{l}P \\
4\end{array}$ & $\begin{array}{l}P \\
5\end{array}$ & $\begin{array}{l}P \\
6\end{array}$ & $\begin{array}{l}\mathbf{P} \\
7\end{array}$ & $\begin{array}{l}\mathbf{P} \\
\mathbf{8}\end{array}$ & $\sum$ \\
\hline Comunicação & 6 & & & 3 & 1 & & 3 & & 1 & & 2 & 1 & & & & & $\mathbf{1}$ & & 2 & & & & & & 20 \\
\hline $\begin{array}{l}\text { Linguagem acessível, } \\
\text { tradução de termos e ajustes } \\
\text { de linguagem }\end{array}$ & 2 & & & 3 & & & 2 & & & & 1 & & & & & & & & & & & & & & 8 \\
\hline Empatia & 3 & & & & & & 1 & & & & & & & & & & & & & & & & & & 4 \\
\hline $\begin{array}{l}\text { Acompanhamento, contato } \\
\text { constante, criação de canais e } \\
\text { proativo }\end{array}$ & 1 & & & & & & & & & & & & & & & & 1 & & 1 & & & & & & 3 \\
\hline $\begin{array}{l}\text { Disponibilidade, abertura ao } \\
\text { diálogo e 'saber quem } \\
\text { procurar' }\end{array}$ & & & & & 1 & & & & 1 & & & & & & & & & & 1 & & & & & & 3 \\
\hline Redes de relacionamento & & & & & & & & & & & 1 & 1 & & & & & & & & & & & & & 2 \\
\hline
\end{tabular}

Fonte: Elaborado pela Autora $(\mathrm{E}=$ Especialista e $\mathrm{P}=\mathrm{PAPN})$

A Especialista 1 considera que muitos termos utilizados pelos Contabilistas são complicados para os empresários de pequenos negócios. Já o Especialista 4 relata que os termos mais simples do dia a dia contábil são compreendidos pelos PAPNs. O cuidado com o uso de jargões e termos técnicos é mencionado pelo Especialista 7:

Eu acho que a linguagem contábil ela é difícil se você não ficar atento, porque como a gente está no meio e a gente fala habitualmente entre a gente, aquele termo soa para nós como um termo consagrado, é óbvio. Mas não é. (Especialista 7)

Para o Especialista 11, por mais que o Contador tente traduzir termos para uma linguagem acessível, a própria complexidade de determinados assuntos representaria um dificultador para o entendimento pelo PAPN:

Eu acho que o papel mesmo, a importância de nós como consultores para o microempresário é tentar fazer ele entender e esclarecer como uma linguagem acessível. Mas, às vezes, a gente enfrenta um pouco de dificuldade pelo assunto ser naturalmente complexo. (Especialista 11)

O ambiente empático aparece nas falas dos Especialistas 1 e 7 como importante para o diálogo entre Contabilista e Empresário. Para a Especialista 1, a oralidade é a forma mais eficiente de comunicação com esse público. Além disso, o Especialista 7 comenta a possibilidade de ajustar a comunicação quando a conversa ocorre pessoalmente de acordo com as pistas visuais, expressão facial e corporal, do empresário:

Às vezes você não percebe que entrou numa linguagem técnica que eles fizeram aquela carinha de paisagem, eu tento ficar percebendo se a pessoa está com carinha de paisagem, quando eu vejo eu paro .... As vezes, pessoalmente, sempre 
pessoalmente, você vê que é nítido, que a pessoa perdeu o fio da meada, que ela está com o ouvido em você, mas pensando outras coisas. (Especialista 7)

A criação de canais de comunicação pode estimular a busca do PAPN pelo Contador, afirma o Especialista 5. Para a Especialista 1, é fundamental a recorrência do contato com o Empresário, o acompanhamento regular. Saber quem é responsável pelo o quê e com quem deve conversar é um diferencial do escritório contábil que atende o PAPN3, enquanto a proatividade do Contador é algo desejado, mas nem sempre percebido pelos Empresários:

De novo, ele [o contador] respondia sempre muito rápida às nossas perguntas. Mas ele nunca ofereceu: "Olha para a atividade de vocês, que é consultoria, o ISS é 5\%, mas se a gente colocar pesquisa e desenvolvimento, o ISS é 2\%." Tive eu que pegar todos os códigos fiscais da prefeitura de São Paulo ... (PAPN 3)

É claro que, assim, já aconteceu dela falar: "Olha, se um dia você precisar de alguma ajuda para alguma planilha desse tipo. "Ela estava lá, ela poderia me ajudar. Mas é uma coisa que não foi muito explícita para mim se isso seria uma tarefa que poderia ser do escritório de contabilidade. (PAPN 1)

As redes de relacionamento apareceram como uma boa prática dos escritórios e contadores que compartilham ideias e sugestões entre si, afirma o Especialista 11. Essas redes também são mantidas pelos PAPNs para indicação e avaliação dos serviços de seus contadores, como exemplifica o Especialista 12: "os empresários se conhecem e consultam lá um ao outro: 'foi bom o trabalho que eles fizeram?"

\subsection{A Consultoria Contábil}

À categoria 'Consultoria' foram associados 190 nós correspondentes a excertos das transcrições que tratavam de falas específicas ao serviço de consultoria às MPEs, utilizandose aqui a definição proposta por Schein (1972) de que consultoria é ajudar "o cliente a perceber, entender e agir sobre fatos inter-relacionados que ocorrem em seu ambiente " ou que sugeririam demandas de apoio aos PAPNs diferentes daquelas associadas às categorias anteriormente apresentadas. A distribuição dos nós entre as subcategorias e os sujeitos da pesquisa é apresentada na Tabela 16: 
Tabela 16: Subcategorias e nós associados à Consultoria

\begin{tabular}{|c|c|c|c|c|c|c|c|c|c|c|c|c|c|c|c|c|c|c|c|c|c|c|c|c|c|}
\hline $\begin{array}{l}\text { Categoria e } \\
\text { Subcategoria }\end{array}$ & $\begin{array}{l}\mathbf{E} \\
\mathbf{1}\end{array}$ & $\begin{array}{l}\mathbf{E} \\
2\end{array}$ & $\begin{array}{l}\mathbf{E} \\
\mathbf{3}\end{array}$ & $\begin{array}{l}\mathbf{E} \\
4\end{array}$ & $\begin{array}{l}\mathbf{E} \\
\mathbf{5}\end{array}$ & $\begin{array}{l}E \\
6\end{array}$ & $\begin{array}{l}\mathbf{E} \\
7\end{array}$ & $\begin{array}{l}\mathbf{E} \\
8\end{array}$ & $\begin{array}{l}\mathbf{E} \\
\mathbf{9}\end{array}$ & $\begin{array}{c}\mathrm{E} \\
\mathbf{1 0}\end{array}$ & $\begin{array}{c}E \\
11\end{array}$ & $\begin{array}{c}E \\
12\end{array}$ & $\begin{array}{c}\mathbf{E} \\
13\end{array}$ & $\begin{array}{c}E \\
14\end{array}$ & $\begin{array}{c}\mathbf{E} \\
15\end{array}$ & $\begin{array}{c}E \\
16\end{array}$ & $\begin{array}{l}\mathbf{P} \\
\mathbf{1}\end{array}$ & $\begin{array}{l}\mathbf{P} \\
2\end{array}$ & $\begin{array}{l}\mathbf{P} \\
\mathbf{3}\end{array}$ & $\begin{array}{l}\mathbf{P} \\
4\end{array}$ & $\begin{array}{l}\mathbf{P} \\
\mathbf{5}\end{array}$ & $\begin{array}{l}\mathbf{P} \\
6\end{array}$ & $\begin{array}{l}\mathbf{P} \\
7\end{array}$ & $\begin{array}{l}\mathbf{P} \\
8\end{array}$ & $\Sigma$ \\
\hline Consultoria & 4 & 3 & 6 & 14 & 26 & 3 & 29 & 19 & 1 & 7 & 8 & 11 & 10 & 1 & 6 & 1 & 1 & 9 & 4 & 10 & 6 & 2 & 4 & 5 & 190 \\
\hline $\begin{array}{l}\text { Desenvolvimento de Plano } \\
\text { de Negócios e orçamentos, } \\
\text { visão longo prazo }\end{array}$ & & & & & 1 & 1 & & 3 & & & & 1 & 4 & & 1 & & 1 & 4 & 2 & 2 & & & 2 & 1 & 23 \\
\hline $\begin{array}{l}\text { Fatores associados à busca } \\
\text { por apoio, aconselhamento, } \\
\text { consultoria }\end{array}$ & & & & 1 & & & 2 & & & 4 & 1 & 1 & & & 1 & & & & & 2 & 6 & & & 1 & 19 \\
\hline Treinamento para PAPN & & 1 & & & 4 & & 3 & & & & 3 & 1 & 2 & & & & & 1 & & 2 & & & & & 17 \\
\hline Relação de Confiança & 1 & & & & & & 1 & 5 & & 2 & 1 & 2 & & & 2 & & & & 1 & & & & & & 15 \\
\hline $\begin{array}{l}\text { Orientação em } \\
\text { administração e gestão }\end{array}$ & & & 1 & 4 & 1 & & 1 & 1 & & & & 2 & 1 & & & & & 2 & & 1 & & & & & 14 \\
\hline $\begin{array}{l}\text { Conhecimento de mercado, } \\
\text { setor, negócio }\end{array}$ & & & 2 & 2 & 2 & 1 & 1 & 4 & & & & & & & & & & & & & & & 1 & & 13 \\
\hline $\begin{array}{l}\text { Aconselhamento de } \\
\text { negócios, estratégia, } \\
\text { planejamento e mercado }\end{array}$ & & & 1 & 1 & 1 & & 2 & 2 & & & 1 & 1 & & & & & & & & 1 & & & 1 & & 11 \\
\hline $\begin{array}{l}\text { Orientação para soluções, } \\
\text { seus riscos e impactos }\end{array}$ & 2 & & & 1 & 3 & & 2 & 1 & & & & & & & & & & 1 & & & & & & & 10 \\
\hline Análises financeiras & & & 1 & & & & 3 & 1 & & & & & & & & & & 1 & & & & & & & 6 \\
\hline Contabilidade Gerencial & & & & & & 1 & 2 & & & & 1 & & 1 & & & & & & 1 & & & & & & 6 \\
\hline $\begin{array}{l}\text { Relacionamento Contador - } \\
\text { PAPN }\end{array}$ & & & & & & & & & 1 & & & 1 & & & & & & & & 1 & & 1 & & 2 & 6 \\
\hline $\begin{array}{l}\text { Acessibilidade econômica à } \\
\text { consultoria }\end{array}$ & & 1 & & & 1 & & 2 & & & & & & & & 1 & & & & & & & & & & 5 \\
\hline Adequação de relatório & & & & & & & 2 & 1 & & & & & & 1 & & & & & & & & & & & 4 \\
\hline Empatia & & & & & 4 & & & & & & & & & & & & & & & & & & & & 4 \\
\hline Flexibilidade e proximidade & & & & & 2 & & & & & & & & 1 & & 1 & & & & & & & & & & 4 \\
\hline $\begin{array}{l}\text { Orientação na busca por } \\
\text { capital, investimentos e } \\
\text { financiamentos }\end{array}$ & 1 & & & & 2 & & & & & & & 1 & & & & & & & & & & & & & 4 \\
\hline Planejamento tributário & & & & & 1 & & 2 & & & & & & 1 & & & & & & & & & & & & 4 \\
\hline Diagnóstico & & & & & 1 & & 2 & & & & & & & & & & & & & & & & & & 3 \\
\hline $\begin{array}{l}\text { Dificuldades enfrentadas } \\
\text { pela MPE }\end{array}$ & & 1 & & 1 & & & & & & & & & & & & & & & & & & & & 1 & 3 \\
\hline $\begin{array}{l}\text { Dinâmica do Escritório } \\
\text { Contábil }\end{array}$ & & & 1 & & & & 2 & & & & & & & & & & & & & & & & & & 3 \\
\hline $\begin{array}{l}\text { Multidisciplinariedade na } \\
\text { atuação }\end{array}$ & & & & & 2 & & & & & & & & & & & 1 & & & & & & & & & 3 \\
\hline $\begin{array}{l}\text { Valorizar, aproveitar os } \\
\text { controles e conhecimento do } \\
\text { PAPN }\end{array}$ & & & & 1 & & & & & & 1 & 1 & & & & & & & & & & & & & & 3 \\
\hline $\begin{array}{l}\text { Acompanhamento, contato } \\
\text { constante, criação de canais } \\
\text { e proativo }\end{array}$ & & & & & & & & & & & & 1 & & & & & & & & & & 1 & & & 2 \\
\hline $\begin{array}{l}\text { Regularidade em vários } \\
\text { âmbitos }\end{array}$ & & & & 2 & & & & & & & & & & & & & & & & & & & & & 2 \\
\hline $\begin{array}{l}\text { Complexidade das normas e } \\
\text { burocracia }\end{array}$ & & & & & & & & & & & & & & & & & & & & 1 & & & & & 1 \\
\hline Formação do Contador & & & & & & & & 1 & & & & & & & & & & & & & & & & & 1 \\
\hline $\begin{array}{l}\text { Gestão/Administração do } \\
\text { Negócio pelo PAPN }\end{array}$ & & & & 1 & & & & & & & & & & & & & & & & & & & & & 1 \\
\hline Honorários do Contador & & & & & & & 1 & & & & & & & & & & & & & & & & & & 1 \\
\hline $\begin{array}{l}\text { Linguagem acessível, } \\
\text { tradução de termos e ajustes } \\
\text { de linguagem }\end{array}$ & & & & & 1 & & & & & & & & & & & & & & & & & & & & 1 \\
\hline Satisfação pessoal & & & & & & & 1 & & & & & & & & & & & & & & & & & & 1 \\
\hline
\end{tabular}

Fonte: Elaborado pela Autora $(\mathrm{E}=$ Especialista e $\mathrm{P}=\mathrm{PAPN})$

As ferramentas de Plano de Negócios e Orçamentos e o planejamento para o longo

prazo foram os temas mais recorrentes dentre os entrevistados, seja nos casos em que alguns 
PAPNs compartilharam suas dificuldades com esses assuntos, seja na indicação feita pelos Especialistas da importância de se atentar para isso na gestão das MPEs.

Dentre os empresários entrevistados, a elaboração e manutenção de um plano de negócios não é frequente. O PAPN 3 contou ter elaborado um plano somente a partir do segundo ano de vida do seu negócio. No primeiro ano, conhecia o "nível mínimo de negócios que precisa ter para pagar as contas". A PAPN 4 elabora seu plano de negócios como parte da avaliação do seu curso de pós-graduação. Porém, até o momento da entrevista não tinha elaborado a parte financeira mesmo. Ela afirma: "Eu tenho isso na cabeça, eu ainda não escrevi porque eu não cheguei nessa parte" (PAPN 4). A PAPN 2 não fez qualquer tipo de planejamento quando iniciou sua agência de conteúdo. Inclusive, acredita que se tivesse feito, não teria aberto o negócio: "Foi uma coisa mal planejada, eu acho. Se eu tivesse planejado mesmo, administrativamente, talvez eu não tivesse nem aberto essa agência". (PAPN 2)

Para a Especialista 8, o empresário com um bom plano de negócios, deveria ter facilidades para levantar capital no mercado, enquanto o Especialista 5 afirma que os empresários com planos elaborados costumam concentrar suas atenções na parte tecnológica ou comercial do negócio: "Plano de negócios eles chegam a ter, mas acabam focando muito mais na parte tecnológica e comercial do que a parte administrativa. " Esse impasse apareceu na fala do Especialista 12 ao se recordar da época em que empreendeu sua empresa de contabilidade:

A gente tinha um grau de investimento elevado no negócio e a gente investia bastante. E eu acho que a gente se preocupou muito com isso. Acho que a gente ficou tão preocupado com isso que acabou esquecendo até um pouco de prospecção de mercado, de conseguir cliente. (Especialista 12)

A Especialista 8 conta que, quando recebe um cliente interessado em abrir uma empresa, mas com desconhecimento aparente do mercado, ela tenta alertá-lo sem cobrar por isso, tenta mostrar a ele a importância de planejar-se. A importância do planejamento foi apontada pela PAPN 7 ao demonstrar suas dificuldades para enfrentar as sazonalidades de faturamento do seu negócio, embora tenha planejado as despesas. A PAPN 1 disse que acredita que sua contadora poderia ter ajudado mais no planejamento, quando questionada sobre o que esperava de seu escritório de contabilidade. Segundo ela: 
Agora, eu acho que pensar o negócio, num planejamento maior, né? Como pensar no plano de negócio, nos investimentos, projeção para o futuro, isso é uma coisa que o escritório poderia ter ajudado um pouco mais. Que é uma coisa que a gente acabou fazendo nesse último período. (PAPN 1)

Para a Especialista 8, o contador tem condições de ajudar no planejamento:

Você consegue trabalhar com previsões. O contador ele te dá formas de você flexibilizar as tuas decisões, de você ter uma maneira de você prever situações, ao longo do tempo. Você consegue verificar e adequar uma melhor maneira de você tratar desses fatores externos. (Especialista 8)

Para a Especialista 15, o contador deve utilizar-se de seu conhecimento fiscal e societário para ajudar o PAPN a pensar estratégias diferenciais para seu negócio: "Ele já tem o domínio da questão societário, o domínio da questão fiscal, então, ele poderia ajudar a formar os diferenciais e, junto com isso, ter algumas ideias, boas ferramentas que ajudariam na gestão dessas empresas".

O Especialista 13 aponta a implantação de inovação como uma necessidade dos PAPNs. Além disso, a fala abaixo da PAPN 2 indica que, apesar de ter consciência da importância da gestão, muitas vezes, o PAPN precisa de alguém que lhe ajude a sair do que ela chama de "mambembismo".

Porque não existe empresa viável que não tenha essa rotina [administrativa]. Isso não existe, né? Não existe isso, não é possivel sobreviver sem isso. Isso faz parte da nossa sobrevivência também e é uma estratégia que tem que ser retomada para a gente poder ter planejamento para ser uma empresa de verdade, né? Às vezes, parece que a gente está num mambembismo, só fazendo matéria e vendendo e fazendo matéria e vendendo. (PAPN 2)

Os aconselhamentos e orientações procurados ou oferecidos, segundo relatos dos envolvidos, envolveram questões que podem ser divididas em gestão, estratégia e mercado. $\mathrm{Na}$ gestão, foram evidenciadas situações em que se espera do profissional apoiador da MPE sugestões de saídas e soluções aos problemas que os PAPNs lhes trazem. A Especialista 1 ressalta a importância de propor soluções, de mostrar as saídas, como relata a PAPN 2: "Olha, eu espero que o contador apresente algumas soluções, que fale: 'Olha, por que você não faz assim? "". Do contrário, constroem-se a visão como aquela que tem a PAPN 8, a de um 
profissional que "só bota os contras", ou a de profissionais que "dificultam ao invés de facilitar" (PAPN 4), ou “alguém que põe sempre empecilhos" (PAPN 6).

No âmbito da estratégia, o estabelecimento de parcerias foi citado. Um exemplo de parceria foi a busca pelos produtos do SEBRAE, como indicado pelo Especialista 5. A Especialista 8 relata situação em que a expertise em tributos ajuda o empresário a modelar sua estratégia:

Então a gente sentou [contadora com clientes que a procuraram sobre um novo negócio] e eu dei toda a consultoria que eles precisavam para dar o 'start' na empresa. Eu ofereci para eles, hoje, numa reunião, eu expliquei tudo para eles. Eu expliquei os três regimes de tributação, eu ofereci o planejamento tributário. De que forma? Por que eles têm que saber? Para implantar o planejamento, o custo da mercadoria, também envolve tributos. Então, de que forma que eles vão atuar? Por exemplo, a parte societária, de que forma que eles vão atuar, ou com um representante comercial, que é serviço, ou vendendo diretamente o produto? De que forma é mais viável? Eu já apresentei o que é objeto social da empresa que está montada e é voltada para o serviço, não para o comércio. Então, eles têm que remexer essa estrutura societária, da constituição da empresa. Então, toda essa parte de consultoria e essa parte de saber se é melhor eles importarem diretamente o produto, ou se eles compram dessa importadora o produto e revendem, no que implica a substituição tributária dos produtos deles. Você acaba dando todas essas informações que eles precisam para sentar e falar: 'Não, vamos fazer dessa maneira'. (Especialista 8)

Quanto ao mercado, para o Especialista 7, repensar o preço pode ser alternativa para o PAPN, embora alguns tenham medo de mexer no preço. A PAPN 4 descreveu sua reflexão sobre como selecionou sua clientela e a PAPN 7 comentou sua ideia de vender para pessoas jurídicas. Esses relatos indicam que a formação de preço e a definição de clientela podem ser motivos para aconselhamentos.

Para os Especialistas 3 e 4, não se trata de substituir o apoio às questões tributárias e societárias, mas, ao contrário, complementá-las, ir além. O Especialista 4 afirma que a solução proposta precisa ser compatível com a realidade da MPE. Em suas palavras: 
Um engenheiro que vai fazer um projeto de uma reforma de uma loja, ou um arquiteto, ele tem que pensar na funcionalidade, talvez não tanto na beleza. Tem que pensar naquilo que dá resultado para empresa. (Especialista 4)

O Especialista 5 ressalta que a decisão em seguir ou não um aconselhamento está nas mãos do PAPN. Em complemento, o Especialista 7 enfatiza a importância de indicar ao PAPN os riscos envolvidos em cada caminho ou solução proposto.

Foram expostas situações em que o PAPN desconhecia ferramentas, conceitos ou outras formas de encontrar soluções para seus problemas. Nesses casos, foram elucidadas orientações com o propósito de treinar os empresários e desenvolver neles a autonomia. $\mathrm{O}$ Especialista 7 defende o treinamento gradativo para que o empresário comece a perceber o valor dos relatórios gerados pela contabilidade, por exemplo. Segundo ele: "eu acho que dá para você gradativamente ir treinando seu cliente para apreciar um relatório financeiro". $\mathrm{O}$ Especialista 5 apontou a importância de conscientizar o PAPN iniciante para a importância de controles básicos de gestão. Para ele, trata-se de contribuir para o amadurecimento dos gestores. Nas palavras dele: “Que os caras saiam de ser um empresário imaturo, imaturo não, mas ainda em formação, para um empresário propriamente dito. " As atividades de treinamento podem ser, inclusive, produtos da consultoria, como era o caso da empresa criada pelo Especialista 12.

A PAPN 4, cujo negócio é na área administrativa, afirma que, muitas vezes, não basta apenas orientar, é preciso acompanhar, fazer junto, "pegar na mão", como disse ela. Ela ainda defende: "se a pessoa não faz com uma conversa, com uma orientação, a gente tem que buscar novas formas de fazer com que os empreendedores, os administradores façam da forma correta." Porém, o despreparo ou a falta de conhecimentos administrativos básicos de alguns empresários dificulta a possibilidade de ajuda, como sugere o Especialista 11:

Às vezes, [a orientação] demanda uma bagagem de noções de negócios, de noções de contabilidade e de administração que, às vezes, o empresário não tem. Muitas vezes o empresário não tem essa formação. Às vezes, o empresário é uma pessoa que trabalhava com um outro tipo de atividade e resolveu abrir uma empresa. Então, nessas situações, a gente percebe que é muito difícil de auxiliar o empresário, fazer com que ele entenda quando o negócio dele está sendo rentável ou quando não está sendo. (Especialista 11) 
Os Especialistas 11 e 13 afirmam que muitos PAPNs não conhecem a contabilidade gerencial, indicando a necessidade de orientação para seu uso. O Especialista 13 contou que, quando era empresário, descobriu a contabilidade de custos em um curso de pós-graduação e, depois de conhecê-la, percebeu quão importante são suas ferramentas para a gestão. Esse desconhecimento da área contábil-gerencial também é indicado pelo Especialista 11:

Eu percebo muito isso em relação ao empresário que acha que contabilidade é aquela de fazer balanço e publicar no jornal e não enxerga que existe uma outra contabilidade, um sistema informação para tomar decisão, que é aquele que ele pode ter dentro da empresa. (Especialista 11)

Nesse contexto de orientação e treinamento, o apoiador precisa considerar e valorizar o conhecimento prévio do empresário. Para o Especialista 4, seria uma postura soberba desconsiderar a bagagem do PAPN. A Especialista 10 afirma que algo que pode funcionar para uma MPE, pode não funcionar para outra. Portanto, não se pode impor práticas "goela abaixo". Considerar o que o cliente já tem ou já faz é uma prática adotada pelo Especialista 11, especificamente relatada quando da informatização de sistemas de controle.

O Especialista 2 afirma que os materiais de treinamento destinados ao público da pequena empresa devem ser "mais mastigados", enquanto o Especialista 5 ressalta em diversas passagens a necessidade do conselheiro da MPE equilibrar a exposição a questões de controle, jurídicas e tributárias no período nascente e frágil do negócio, do contrário, “começa a virar feijoada para recém-nascido. Começa a ficar muito pesado para um cara que tem tanto problema. "

Para apoiar o PAPN nas questões acima apresentadas, bem como treiná-lo, é preciso ter conhecimento em áreas que vão além da contabilidade, como explicita a Especialista 8:

Mas o que foge dali são outras questões, são questões de mercado, que na verdade estão envolvidas na parte contábil, mas que são questões que o profissional contábil tem que saber e que não é contabilidade propriamente dita. (Especialista 8)

De acordo com o Especialista 3, é preciso conhecer técnicas de administração, o mercado de atuação e o negócio do cliente, segmentar o atendimento para se tornar especialista em determinado setor. A necessidade de conhecimento em administração também aparece na fala do Especialistas 12, ao citar a experiência de seu escritório de consultoria: 
"como consultoria entraria, pelo menos do meu ponto de vista, uma forma mais de orientação em relação à administração financeira."

O conhecimento das particularidades da empresa é apontado pelos Especialistas 4, 5, 6, 7, 8. O Especialista 6 enfatiza a importância desse entendimento profundo fazendo analogia ao ato de mergulhar, para ele: "seria interessante se esse profissional de contabilidade realmente mergulhasse nos negócios do pequeno e microempresário, mergulhasse mesmo nos negócios".

Para conhecer as especificidades da MPE, o consultor precisa receber do PAPN informações sobre o negócio. Esse compartilhamento de informação da empresa envolve a confiança do empresário no profissional que lhe apoia. Os Especialistas 10 e 11 afirmaram perceber situações em que o PAPN tem medo de abrir informações ao contador. Para a Especialista 8, a confiança é fundamental para que o cliente se abra ao contador, inclusive, sobre situações problemáticas. A Especialista 15 afirma que o PAPN "vê que pode confiar quando essa informação não for usada contra ele, quer dizer, que o contador não vai abrir a boca e passar a informação nem para o Fisco, nem para os concorrentes. " A ética do profissional contábil é ponto fundamental no estabelecimento da confiança, segundo a Especialista 8.

Foram mencionadas razões para o PAPN procurar ajuda especializada. Para solucionar algum problema, afirmou o PAPN 5, para aconselhamentos no momento de iniciar um novo negócio, indicou o Especialista 11, para sanar dúvidas ou implantar contabilidade gerencial, principalmente quando há o cenário em que a contabilidade oficial não contém todas as operações da empresa, disse o Especialista 7 ou por alguma obrigação legal que demande um especialista, afirma o Especialista 4. Existem também situações que indicam a maior propensão do PAPN à consultoria, tais como a participação em licitações e o maior nível de profissionalização da gestão, segundo o PAPN5 e a expansão do negócio com consequente apelo à visão de longo prazo, colocou a Especialista 10. A efetividade da consultoria é maior quando o PAPN é diretamente interessado no seu resultado, explicou o Especialista 12 ao compartilhar sua experiência como consultor que ajudava a empresa a se preparar para receber capital externo.

A PAPN 8 expôs seu dilema para buscar apoio: falta de tempo versus ausência de trabalho que lhe paralisa. Para ela, essa questão pesa mais do que o custo dos serviços, visto que ela ainda encontra apoio de que precisa gratuitamente. Em suas palavras: 
Tem os cursos do SEBRAE, tem muitas palestras de graça, de gestão de negócios, mas acontece uma coisa comigo que eu não sei se acontece com as outras pessoas, quando o negócio assim, quando eu estou com muito trabalho, eu não tenho tempo, e quando eu estou sem dinheiro nenhum, eu fico paralisada de medo. (PAPN 8)

O recurso financeiro para pagar uma consultoria nem sempre está disponível na MPE. O Especialista 2, em seus projetos educacionais voltados a esse público considera o ambiente de recurso escasso, no qual a gratuidade ou redução de preços de materiais é almejada. O Especialista 7 advoga uma consultoria que agregue valor à empresa, porém, a um custo pagável, segundo ele, uma forma de viabilizar isso é o ajuste do honorário ao tamanho do negócio, com aumento de valores à medida que a empresa cresce. A Especialista 15 explicita sua experiência de viabilização dos serviços de aconselhamento por meio de consultorias coletivas. Em suas palavras:

Uma das formas que eu vi que dá mais resultado em consultoria de pequenas empresas é você fazer uma consultoria coletiva, dar para o cara, nem para o contador é produtivo, nem para o empresário, uma pessoa exclusiva para ele. (Especialista 15)

Experiência similar foi relatada pelo Especialista 4 com a prática de plantões de dúvidas para tirar dúvidas jurídicas das empresas de uma incubadora, em uma espécie de mutirão.

A contabilidade gerencial e seus instrumentos perpassou as falas em muitas ocasiões. A implantação de relatórios gerenciais que ajudem o PAPN: na formação do preço de seu produto; na apuração de margens de contribuição, de custos e da lucratividade real do negócio foi sugerida pelo Especialista 7 como um dos objetivos da consultoria contábil. O Especialista 6 inclui a elaboração de orçamentos prospectivos, que permitam ao PAPN pensar no longo prazo e preparar-se para as mudanças de mercado. Essa visão prospectiva do apoio contábil é enfatizada pelo Especialista 3. A linguagem dos relatórios deve ser simplificada, afirma a Especialista 8. Complementarmente, o Especialista 7 sugere o uso de gráficos para facilitar a leitura e o entendimento do leitor. Para o Especialista 14, é fundamental que essas informações úteis para a tomada de decisão do PAPN estejam, além de em uma linguagem simples, como sugerido pelos Especialistas 7 e 8, em um único lugar, de 
forma curta e facilmente consultada, similar ao quadro de bordo de um avião, que permite ao piloto o ajuste rápido de rota. Dessa maneira, expectativas como a PAPN 2 com relação ao contador seriam atendidas, a saber:

[Imagina o contador como] um cara que entende de finanças e alguém que vai me ajudar a equilibrar as finanças da minha empresa de alguma maneira, que vai me ajudar a pensar em preço, vai me ajudar a fazer fluxo de caixa. É, vai me ajudar a precificar o meu conteúdo. (PAPN 2)

Sobre a implantação da contabilidade gerencial, o Especialista 11 ressalta: " $A$ gente [contadores] tem plenas condições de fazer [de implantar e orientar]. E é nosso papel fazer. Mas, assim, a operacionalização dessas ferramentas nós não temos condições de fazer porque realmente não está dentro da empresa."

O planejamento tributário foi apontado pelos Especialistas 5, 7 e 8 como objeto da consultoria contábil para a MPE. O Especialista 4 inclui questões de regularização em diversas áreas, inclusive a ambiental, a qual é bastante negligenciada pelos PAPNs, segundo ele.

Dentro da consultoria também estariam orientações e aconselhamento sobre: (i) as melhores formas de captar recurso, segundo os Especialistas 1 e 12; (ii) o preparo para diligências de futuros investidores, como mencionado pelo Especialista 5; e (iii) a elaboração de projetos, indica a Especialista 1.

Para captar o estado em que a MPE se encontra, suas dificuldades e potencialidades, um diagnóstico deve ser feito antes do início da consultoria. $\mathrm{O}$ Especialista 7 afirmou começar seu trabalho de consultoria com um novo cliente por meio de um relatório que ele mesmo chama de diagnóstico. Esse mesmo recurso foi citado pelo Especialista 5, o qual acrescentou a importância da multidisciplinariedade dessa etapa, tal como é a necessidade de consultoria ao PAPN em múltiplas áreas.

O Especialista 16 usou o termo 'integrador' para definir o contador em uma atuação na consultoria. Na situação relatada por ele, o contador deveria integrar a empresa, o empresário-administrador e outros consultores externos. Outras situações nas quais o consultor atuou como integrador foram mencionadas por outros especialistas. O Especialista 5, que atua como consultor interno para empresas incubadas afirma fazer a interface entre as áreas administrativa, representada pelo 
gestor da empresa, e contábil, representada pelo contador externo. O Especialista 12 relatou sua experiência em consultoria para investimento, quando atuava integrando os recursos humanos da empresa com recursos externos para otimizar as rotinas administrativas e gerar informações mais confiáveis e tempestivas.

O Especialista 7 expôs uma situação em que foi consultado pelo cliente, mas não se sentiu apto para orientá-lo:

Na questão da motivação e liderança, problemas pessoais com funcionários, aí eu já não tenho certeza [se o contador poderia ajudar]. Acho que talvez existam profissionais mais competentes para isso. Em um bate papo, sim, [mas] não em uma relação de contador-cliente. Às vezes, de amizade, a gente fala. O cara está frustrado com o funcionário e você fala dos teus problemas também “Olha, não é só na tua clínica, eu também tenho problemas com funcionários, mas a gente tem que conviver, é uma equipe, blá blá bla, blá blá bla, blá blá blá”. Acho que no papel da informação sim [o contador pode ajudar], no resto eu já não tenho tanta certeza. Acho que tem gente mais competente. (Especialista 7)

$\mathrm{O}$ relato do Especialista 7 pode ser apreendido ainda no âmbito do papel integrador do consultor, à medida que entende os limites da sua especialidade ou da sua capacidade técnica para oferecer orientação e sugere a procura por outro profissional, outro especialista para auxiliar o PAPN, retomando assim o papel integrador sugerido pelo Especialista 16.

O Contador tem uma proximidade privilegiada como o PAPN, sendo muitas vezes o único profissional a quem o empresário da MPE pode recorrer. Como evidencia a fala do Especialista 13 e corrobora a fala da Especialista 15:

Porque a partir do momento que o pequeno empresário não tem essa fundamentação de gestão de custos ou gestão financeira, o cara mais próximo dele que domina alguma coisa sobre isso é o contador dele. (Especialista 13)

E nada melhor do que essa pessoa a ajudar já que conhece a empresa, que tem os números, que já está em contato com a empresa, tem tudo para ser 
exatamente a pessoa que pode ajudar esse pequeno empresário na gestão dele. (Especialista 15)

A partir das falas dos sujeitos da pesquisa acima apresentadas, apreende-se que a consultoria contábil a ser oferecida ao PAPN envolve aconselhamentos acerca do mercado, das estratégias e da gestão da MPE. Para isso, algumas ferramentas e relatórios mínimos de controles e gestão foram citados, tais como plano de negócios, fluxo de caixa, orçamentos prospectivos que permitam simulações, contabilidade de custos, ponto de equilíbrio e gerenciamento de capital de giro e de estoques. Os relatórios devem ter linguagem clara e simples, adequados ao contexto da MPE e disponível de forma rápida e, de preferência, em uma única folha. $\mathrm{O}$ apoio em planejamento tributário incluiu a busca por diferenciais competitivos, alinhados à estratégia da MPE. O treinamento é uma prática do consultor, que deverá ajudar o PAPN a desenvolver autonomia para os assuntos alvo de treinamento, o qual pode ser oferecido pelo consultor ou ser indicado por ele. Para que o contador consultor tenha acesso às informações completas e verdadeiras da empresa, faz necessário o estabelecimento de uma relação de confiança com o empresário e o comportamento ético do profissional contribuiu para que o PAPN veja no contador alguém em quem possa confiar. Por fim, o contador para atuar como consultor, tal como indicado pelos entrevistados, precisa desenvolver conhecimentos em multiáreas, em especial, na administração. 


\section{Proposições}

O ambiente mercadológico, burocrático e tributário da MPE e o perfil do seu proprietário-administrador têm impacto na consultoria contábil a ser oferecida ao PAPN. Em um ambiente muitas vezes desfavorável aos pequenos negócios (The World Bank, 2014; Deloitte, 2013, 2012), onde a concorrência com grandes empresas e a luta diária pela sobrevivência são dificuldades correntes, o perfil do PAPN impacta diretamente a gestão da MPE, que tem por característica comum a centralização e a informalidade.

Os empresários da pequena empresa iniciam um negócio próprio por diversas razões, que muitas vezes envolvem sonhos e satisfação pessoal. Aqueles com perfil empreendedor, ou seja, com visão e compromisso com a realização de seus sonhos (Filion, 1999), tendem a buscar informação, são mais propícios à profissionalização da gestão, preocupam-se com o longo prazo e utilizam a contabilidade para a tomada de decisão. Por outro lado, os empresários sem esse perfil procuram o contador exclusivamente para serviços físcais e de departamento de pessoal, normalmente concentram-se nas rotinas operacionais do negócio e mantêm uma gestão focada no imediatismo.

O PAPN está, muitas vezes, envolvido na atividade operacional, além de ter que se ocupar da gestão do negócio. Portanto, seu tempo é um recurso escasso. Além disso, a literatura indica a centralização da gestão na figura do dono (Bortoli Neto, 1980) e a deficiência em competências administrativas (Raifur, 2013; Longenecker et al., 1998; Casa Nova, 1996) como características comuns desses empresários.

A falta de separação clara entre as finanças pessoais e da empresa é uma prática comumente encontrada na MPE, bem como a omissão de receitas para redução de tributos e a informalidade, completa ou parcial, na contratação de funcionários. Os recursos tecnológicos e financeiros são geralmente escassos (Batista et al., 2012; Trindade et al., 2010; SEBRAE, 2007; Kassai \& Casa Nova, 2006; Machado et al., 2006), o acesso a capital é restrito (Daskalakiset al., 2013; Deloitte, 2012) e as demandas por apoio ou informações se diferenciam dependendo da fase vivida pela MPE, se está iniciando-se, se assentando ou consolidando-se no mercado ou, até mesmo, passando por dificuldades que podem culminar em sua extinção (Dyer \& Ross, 2007).

A relação da MPE com o contador ou o escritório contábil está fortemente calcada na assessoria para assuntos fiscais (apuração de impostos e cumprimento de obrigações 
acessórias) (Marion, 2006), de departamento de pessoal (rotinas de contratação, férias e rescisão, fechamento de folha de pagamento de funcionários e apuração de encargos trabalhistas) e paralegais (formalização/constituição, alterações e encerramento de empresas), como apontam Miranda et al., (2008). O grande número de obrigações acessórias, a complexidade das leis tributárias e suas constantes alterações fazem parte da realidade dos escritórios contábeis. Além disso, existe o dilema dos honorários dos serviços contábeis, que é visto como muito alto pelos PAPNs e como baixo pelos contabilistas, frente ao volume de trabalho e responsabilidade atreladas aos serviços.

O conhecimento acerca do perfil do PAPN, do negócio da MPE, do mercado em que atua (ambiente da consultoria) é imprescindível para pensar o formato e conteúdo da consultoria contábil a ser oferecida ao empresário. Um diagnóstico deve ser feito inicialmente para captar as dificuldades e as potencialidades da empresa a fim de conhecer a empresa atendida (Dyer \& Ross, 2007; Padula, 1996) para se propor solução ou sugerir caminhos adequados. Nesse momento, devem ser expostos claramente todas as implicações e riscos envolvidos em cada sugestão para que a decisão do PAPN seja embasada e consciente.

A natureza do serviço da consultoria a ser oferecida às MPEs pelos contadores pode ser dividida em três categorias: ferramentas, aconselhamento e treinamento.

As ferramentas, relatórios ou rotinas, básicas e essenciais para auxiliar a gestão e a tomada de decisão do PAPN, cuja implantação seria sugerida pelo consultor contábil, incluiriam o Plano de Negócios; o Fluxo de Caixa prospectivo e; o Orçamento prospectivo, que permitam simulações de cenários, tal como proposto por Casa Nova (1996); contabilidade de custos; o controle e a administração do capital de giro e dos estoques; o levantamento do ponto de equilíbrio; e as rotinas de controles mínimos administrativos (Berry et al., 2006). A efetividade da implantação e uso dessas ferramentas dependerão de sua aceitação pelo PAPN. Para isso, é importante entender com profundidade suas necessidades e expectativas, valorizando e aproveitando seus eventuais controles já estabelecidos e adaptando os relatórios a uma linguagem simples e com significado para o empresário, além de estarem à disposição em um único lugar, de forma simples e rápida (Casa Nova, 1996).

Os aconselhamentos ou orientações têm como principal foco ajudar o PAPN a reduzir o seu envolvimento com aspectos da operação, pelo menos em alguns momentos, para pensar no negócio, sua estratégia e administração e a desenvolver sua visão empreendedora. No que concerne à estratégia, o consultor contábil pode extrapolar a atuação no planejamento 
tributário das MPEs (Batista et al., 2012) oferecendo a esse empresariado a sua expertise societária e em tributos para que alternativas possam ser simuladas e comparadas, objetivando diferencial competitivo para o negócio. Além disso, as orientações versam sobre a busca pelas melhores alternativas de financiamento, a elaboração de projetos para captação de recursos e a preparação do negócio para as diligências de possíveis investidores externos.

Ao consultor contábil caberia alertar o PAPN, com pouca experiência ou pouco conhecimento em administração, para a importância da profissionalização da gestão, de planejar-se com uma perspectiva de longo prazo, organizando formalmente as ideias e os planos que o empresário, geralmente, 'carrega na cabeça', e das práticas que lhe ajudam a prever e se preparar para as mudanças de mercado, essenciais para a continuidade e sustentabilidade do negócio. A manutenção das redes de relacionamento, de compartilhamento de experiências, erros e boas práticas entre os PAPNs também seriam incentivados pelo consultor.

O treinamento é parte do trabalho do consultor, segundo Schein (1995). Dentro do escopo da consultoria contábil ele é direcionado ao entendimento, ao 'como fazer' algo e objetiva a autonomia do PAPN. Trata-se de apoiar esse empresário no seu processo de amadurecimento enquanto gestor. Quatro temas são alvo principal do treinamento na MPE: (i) a separação da vida da empresa e da vida pessoal do empresário, o que na contabilidade é chamado de 'princípio da entidade', incluindo orientações sobre finanças pessoais; (ii) o processo de informatização do governo com consequente impacto em práticas fiscais evasivas; (iii) o entendimento dos regimes de caixa e competência e a importância desse último para avaliar o desempenho do negócio; e, por fim, (iv) o potencial de ajuda à gestão da MPE da contabilidade, em especial, da contabilidade gerencial. Esses temas são, comumente, os mais urgentes de treinamento na MPE. Porém, outros assuntos podem ser demandados na atuação como contador-consultor do PAPN. Para que realmente ocorra a transferência de conhecimento do consultor contábil ao PAPN, é preciso que haja compatibilidade de contextos entre os dois e cabe ao consultor adaptar-se (Dalley \& Hamilton, 2000).

A consultoria contábil demanda uma relação de confiança entre o contador e o PAPN (Gooderham et al., 2004; Bennett \& Robson, 1999), para que esse empresário abra inteiramente as informações ao profissional, a fim de que o consultor possa alertar para os riscos e propor soluções e caminhos alternativos. Cabe ao consultor a atenção para propor soluções compatíveis à realidade e à capacidade econômica da MPE, além de adotar uma 
linguagem simples e empática, como também sugerem Villa et al. (2013) e IFAC (2010) e, de preferência, presencial e informal (Stone, 2011; Gooderham et al., 2004; Dalley \& Hamilton, 2000).

O consultor precisa ter sensibilidade para dosar a "pressão" sobre o PAPN pela preocupação com controles administrativos, para não prejudicar a atenção do empresário a outras áreas da empresa, principalmente quando o PAPN é o único responsável pelo operacional do negócio.

Dado o contexto de recurso escasso nas MPEs, a viabilização econômica da consultoria contábil passaria por consultorias coletivas e mutirão de atendimento, o que é chamado por Donadone et al. (2012) como massificação da consultoria. Além disso, a especialização do contador em segmentos ou setores pode representar otimização de recursos do profissional contábil.

Por fim, para oferecer a consultoria contábil, cujas características foram acima propostas, é imprescindível que o contador busque preparo em múltiplas áreas, especialmente em administração (IFAC, 2010; Miranda et al., 2008). 


\section{Considerações Finais}

As MPEs são obrigadas por lei a manter um sistema de contabilidade que deve ser elaborado por um contabilista habilitado. Essa obrigação aproxima o contador ou o escritório contábil da MPE invariavelmente. Porém, para além da obrigatoriedade de um sistema de contabilidade, essas empresas comumente procuram esses profissionais para rotinas fiscais, de departamento de pessoal e outras de cunho burocrático, como abertura, alterações e encerramento de empresas, por exemplo. Esse contexto, bem como o número de MPEs existente, fazem dessas empresas a principal clientela dos contadores e escritórios de contabilidade.

Em um cenário de recursos escassos, luta por sobrevivência e dificuldades variadas, os PAPNs, que contam com a assessoria do profissional contábil, muitas vezes não têm recursos financeiros suficientes para contratar outro especialista, principalmente no caso de microempresas em fase de se estabelecer no mercado ou em situação de crise. Portanto, seria o contador o profissional da área de gestão mais próximo do PAPN, tornando o apoio desse profissional a esse empresariado relevante.

Embora existam muitos trabalhos sobre os aspectos envolvidos na consultoria oferecida às MPEs e PMEs, eles não caracterizam essa consultoria em si, especialmente a consultoria contábil.

Pelas razões acima apresentadas, o objetivo da pesquisa foi caracterizar a consultoria contábil a ser oferecida pelos profissionais de contabilidade aos Proprietários Administradores de Pequenos Negócios (PAPNs) com o propósito de ajudá-los na lida com as dificuldades específicas das Micro e Pequenas Empresas (MPEs). Para isso, foram realizadas 23 entrevistas com oito PAPNs e quinze especialistas, a fim de captar a partir da percepção desses interlocutores as dificuldades enfrentadas pelas MPEs e pelos seus PAPNs, bem como o apoio profissional que poderiam receber para o enfrentamento dessas dificuldades. Após a análise das falas dos 24 interlocutores (23 entrevistas e o relato de um professor, documentado por relato de memória), as quais passaram por extenso processo de codificação com uso do software Nvivo, um conjunto de características foi levantado e concerne a aspectos sobre a natureza do serviço da consultoria contábil, dividida em três categorias: ferramentas, aconselhamento e treinamento; além de sua ambiência e possibilidades de viabilização econômica. 
A consultoria contábil, tal como demonstrado na Figura 2 do capítulo terceiro deste trabalho, está inserida no contexto da MPE e dialoga com outros aspectos que se interrelacionam: (a) as características comuns do seus PAPNs; (b) a tributação e o conjunto de regras legais que deve ser observado por esses empresários e por seus Contadores ou Escritórios Contábeis, (c) cuja prática profissional é influenciada pelo excesso de obrigações fiscais acessórias, pela percepção de baixo honorário recebido por esses serviços e por uma formação educacional, a qual, geralmente, não é voltada para as demandas do pequeno negócio; e (d) a comunicação entre consultor-contador e PAPN que permeará todo o processo de consultoria.

O contador-consultor deve atuar como um integrador, ora integrando múltiplos conhecimentos, especialmente contábil e administrativo, ora integrando os administradores da empresa e seus outros apoiadores, internos e externos.

No caso de PAPNs com pouco conhecimento de gestão que procura no profissional contábil o apoio para melhorar a administração do seu negócio, o consultor deverá ultrapassar os limites da área contábil, auxiliando esse empresário em assuntos de finanças gerais, marketing, jurídico etc., integrando conhecimentos básicos dessas áreas para apoiar o PAPN de forma multitemática.

À medida que esse PAPN desenvolve suas habilidades de administração, implanta uma gestão profissional, sua empresa cresce e contrata outros apoiadores internos e externos, o contador-consultor, com seu conhecimento acerca daquele negócio, passa a ser um integrador desses profissionais e da administração, auxiliando, dessa forma, na otimização de recursos.

Por fim, não se propõe aqui a substituição dos serviços oferecidos hoje pelos escritórios contábeis às MPEs, os quais são vistos pelos PAPNs como a principal função do contador, mas sim o seu complemento com o intuito de ajudar esse empresariado a superar as dificuldades específicas das empresas de menor porte. Afinal, como afirmam Marriott e Marriott (2000), os serviços tradicionais podem representar uma janela de oportunidade para a consultoria contábil.

Sugere-se pesquisas futuras sobre: a formação do contador e como preparar (ou se deveria preparar) para as práticas do escritório contábil demandadas pelas MPEs; o impacto da especialização em determinados segmentos pelo escritório contábil em seu desempenho; o 
impacto das diferenças de carga tributária e volume de obrigações entre os regimes tributários, Simples, Presumido e Real, na decisões de omissão de receita ou no desestímulo ao crescimento da MPE; e o efeito da múltipla jornada, mãe, dona de casa e empresária na vida das mulheres empreendedoras. 


\section{Bibliografia}

Amaral, J. V., \& Casa Nova, S. P. (jul/dez de 2010). Os Fatores de Insucesso das Empresas de Pequeno Porte e a Contabilidade: Um Estudo em Unidades Lotéricas. Sociedade, Contabilidade e Gestão, 5(2).

Batista, F. F., Freitas, E. C., Soares, S. J., \& Rêgo, T. d. (2012). Uma Investigação acerca da Mortalidade das Microempresas e Empresas de Pequeno Porte da Cidade de Sousa, PB. REUNIR - Revista de Administração, Contabilidade e Sustentabilidade, 56-71.

Bennett, R. J., \& Robson, P. J. (1999). The use of external business advice by SMEs in Britain. Entrepreneurship \& Regional Development, 11, 155-180.

Bennett, R. J., \& Robson, P. J. (2004). The role of trust and contract in the supply of business advice. Cambridge Journal of Economics, 28(4), 471-488.

Bennett, R. J., Obson, P. J., \& Bratton, W. J. (2001). The influence of location on the use by SMEs of external advice and collaboration. Urban Studies, 38(9), 1531-1557.

Berry, A. J., Sweeting, R., \& Goto, J. (2006). The effect of business advisers on the performance of SMEs. Journal of Small Business and Enterprise Development, 13(1), $33-47$.

Blackburn, R. A., Carey, P., \& Tanewski, G. (2010). The Role of Trust, Relationships and Professional Ethics in the Supply of External Business Advice by Accountants to SMEs. SSRN Electronic Journal, 1-42.

Block, P. (2011). Flawless Consulting: A Guide to Getting Your Expertise Used. San Francisco: Pfeiffer.

BNDES, B. N. (2011). Circular No 34, de 06 de setembro de 2011. Normas Reguladoras do Produto BNDES Automático.

Bortoli Neto, A. d. (1980). Dissertação de Mestrado apresentada ao Departamento de Administração da FEA. Tipologia de Problemas das Pequenas e Médias Empresas. São Paulo: Universidade de São Paulo.

BRASIL. (27 de Novembro de 1984). LEI No 7.256. Brasília, DF.

BRASIL. (5 de Outubro de 1988). Consituição da República Federativa do Brasil de 1988. Brasília.

BRASIL. (5 de Dezembro de 1996). LEI Nº 9.317. Brasília, DF.

BRASIL. (Outubro de 5 de 1999). LEI No 9841. Brasília, DF. 
BRASIL. (10 de Janeiro de 2002). Lei n 10406 - Código Civil Brasileiro. Código Civil Brasileiro. Brasília.

BRASIL. (14 de Dezembro de 2006). Lei Complementar n.123. Estatuto Nacional da Microempresa e da Empresa de Pequeno Porte. Brasília, DF.

BRASIL. (s.d.). Portal do Empreendedor. Acesso em 9 de Setembro de 2014, disponível em http://www.portaldoempreendedor.gov.br/mei-microempreendedor-individual

Carey, P. J. (2015). External accountants' busuness advice and SME performance. Pacific Accounting Review, 27(2).

Carland, J. W., Hoy, F., R.Boulton, W., \& Carland, J. A. (1984). Differentiating Entrepreneurs from Small Business Owners: A Conceptualization. Academy of Management Review, 354-359.

Carneiro, J. D., \& Dall'Agnol, R. M. (2004/2005). A consultoria em gestão realizada pelo contabilista como alternativa de redução da mortalidade das MPE. Revista Catarinense da Ciência Contábil, 4(10), 9-23.

Carter, A. J., Burritt, R. L., \& Pisaniello, J. D. (2013). The dual roles for accountants in sustaining rural communities. Accounting Research Journal, 2, pp. 130-153.

Carter, S., Mason, C., \& Tagg, S. (2006). Lifting the Barriers to Growth in UK Small Businesses. . London: Federation of Small Businesses.

Casa Nova, S. P. (1996). Dissertação Mestrado em Ciências Contábeis. As empresas de pequeno porte e a contabilidade. São Paulo: Programa de Pós- Graduação em Ciências Contábeis, Departamento de Contabilidade da Faculdade de Economia, Administração e Contabilidade da Universidade de São Paulo.

Cavalcante, C. H., \& Schneiders, P. M. (2008). A contabilidade como geradora de informações na gestão de micros e pequenas . RBC Revista Brasileira de Contabilidade.

CFC, C. F. (5 de dezembro de 2012). Resolução CFC nº 1.418 . ITG 1000 - Modelo Contábil para Microempresa e Empresa de Pequeno Porte. Brasília.

Charmaz, K. (2006). Constructing Grounded Theory: A Practical Guide Through Qualitative Analysis. Londres: Sage .

Concistré, L. (2012). Consultoria: uma opção de carreira. Rio de Janeiro: Elsevier.

Conselho Federal de Contabilidade, C. (2015). http://portalcfc.org.br/. Acesso em 18 de Julho de 2015, disponível em Quantos Somos: http://www3.cfc.org.br/spw/crcs/ConselhoRegionalAtivo.aspx

CPC, C. d. (2009). Pronunciamento Técnico PME: Contabilidade para Pequenas e Médias Empresas. 
Curran, J., \& Blackburn, R. A. (2001). Researching the Small Enterprise. London: Sage.

Dalley, J., \& Hamilton, B. (2000). Knowledge, Context and Learning in the Small Business. International Small Business Journal, 18(3), pp. 51-59.

Daskalakis, N., Jarvis, R., \& Schizas, E. (2013). Financing practices and preferences for micro and small firms. Journal of Small Business and Enterprise Development, 20(1), 80-101.

David Filho, B. (2013). http://www.convecon.com.brq. Acesso em 12 de Novembro de 2014, disponível em $23^{\circ}$ Convenção dos Profissionais de Contabilidade do Estado de São Paulo: http://www.convecon.com.br/download/ITG1000.pdf

Deloitte. (2012). As PMEs que Mais Crescem no Brasi:l Um estudo sobre os desafios do ambiente de negócios no caminho das empresas emergentes.

Deloitte. (2013). Empresas e empreendedores O novo ranking das PMEs e um perfil dos líderes das emergentes em 8 anos da pesquisa.

Donadone, J. C., Silveira, F. Z., \& Ralio, V. R. (2012). Consultoria para pquenas e médias empresas: as formas de atuação e configuração no espaço de consultoria brasileiro. Gestão \& Produção, 19(1), 151-171.

Dyer, M. L., \& Ross, C. A. (2007). Advising the Small Business Client. International Small Business Journal, 25(2), pp. 130-151.

Emerson, R., Fretz, R., \& Shaw, L. (1995). Processing Fieldnotes: Coding Memoing. Em Writing ethnographic fieldnotes. Chicago: The University of Chicago Press.

Fabretti, L. C. (2011). Prática Tributária da Micro, Pequena e Média Empresa. São Paulo: Atlas.

Fernandes, E. M., \& Maia, Â. (2001). Grounded Theory. Em E. M. Fernandes, Â. Maia, \& L. S. Almeida, Métodos e técnicas de avaliação: contributos para a prática e investigação psicológicas (pp. 49-76). Braga: Universidade do Minho. Centro de Estudos em Educação e Psicologia.

Ferronato, A. J. (2011). Gestão Contábil-Financeira de Micro e Pequenas Empresas Sobrevivência e Sustentabilidade. São Paulo: Atlas.

Filion, L. J. (1999). Diferenças entre sistemas gerenciais de empreendedores e operadores de pequenos negócios. Revista de Administração de Empresas, 39(4), 6-20.

Gooderham, P., Tobiassen, A., Doving, E., \& Nordhaug, O. (2004). Accountants as sources of business advice for small firm. International Small Business Journal, 22(1), 5-22.

Halabi, A. K., Barrett, R., \& Dyt, R. (2010). Understanding financial information used to assess small firm performance: An Australian qualitative study. Qualitative Research in Accounting \& Management, 7(2), pp. 163-179. 
Hochsprung, R., Borges, J. L., Freitas, C. L., Espíndola, E. E., \& Ventura, C. (2011). Obrigatoriedade da Escrituração Contábil nas Micro e Pequenas Empresas na Concepção dos Contabilistas da Grande Florianópolis. Revista Ambiente Contábil, $3(1), 20-36$.

Hopper, T., Koga, T., \& Goto, J. (1999). Cost accounting in small and medium sized Japanese companies: an exploratory study. Accounting and Business Research, 30(1), pp. 7386.

IASB, I. A. (Junho de 2013). A Guide for Micro-sized Entities Applying the IFRS for SMEs (2009). Londres, Reino Unido: IFRS Foundation.

IBGE, I. B. (2014). Estatística do Cadastro Central de Empresas 2012. Rio de Janeiro: IBGE.

IFAC, I. F. (Abril de 2010). The Role of Small and Medium Practices in Providing Business Support to Small- and Medium sized Enterprises. Information Paper Small and Medium Practices Committee. Nova Iorque.

IFRS Foundation. (Junho de 2013). A Guide for Micro-sized Entities Applying the IFRS for SMEs (2009). Londres, Reino Unido.

Jarvis, R., \& Rigby, M. (2012). The provision of human resources and employment advice to small and medium-sized enterprises: The role of small and medium-sized practices of accountants. International Small Business Journal, 30(8), 944-956.

Jay, L., \& Schaper, M. (2003). Which advisers do micro-firms use? Some Australian evidence. Journal of Small Business and Enterprise Development, 10(2), 136-143.

Johnson, S., Webber, D. J., \& Thomas, W. (2007). Which SMEs use external business advice? A multivariate subregional study. Environment and Planning A, 8, 1981-1997.

Kassai, J. R., \& Casa Nova, S. P. (2006). Pequenas Empresas - Como é difícil "levantar dinheiro"! ConTexto, 6(9).

Lima Junior, M. P., \& Carvalho, V. G. (2010). A Contabilidade no Contexto da Análise Financeira: Um Estudo nas Indústrias Têxteis em Natal/RN Ano 2008. Revista Ambiente Contábil, 2(1), 1-14.

Lima, E. d. (2001). As Definições de Micro, Pequena e Média Empresas Brasileiras como Base para a Formulação de Políticas Públicas. ANAIS do II EGEPE - Encontro de Estudos sobre Empreendedorismo e Gestão de Pequenas Empresas, (pp. 421-436). Londrina/PR.

Lincoln, I. S., \& Guba, E. G. (2006). Controvérsias paradgmáticas, contradições e confluências emergentes. Em N. K. Denzin, \& I. S. Lincoln, O Planejamento da Pesquisa Qualitativa: Teorias e abordagens (pp. 169-192). Artmed Bookman.

Longenecker, J. G., Moore, C. W., \& Petty, J. (1998). Administração de Pequenas Empresas. (M. L. Rosa, \& S. Stancatti, Trads.) São Paulo: Person Education. 
Machado, M. A., Machado, M. R., \& Callado, A. L. (2006). Análise Dinâmica e o Financiamento das Necessidades de Capital de Giro das Pequenas e Médias Empresas localizadas na cidade de João Pessoa, PB: Um Estudo Exploratório. BASE - Revista de Administração e Contabilidade da Unisinos, 3(2), 139-149.

Machado, M. J. (2013). Balanced Scorecard: Um estudo empírico sobre pequenas e médias empresas. Revista Brasileira de Gestão de Negócios, 15(46), pp. 129-148.

Marion, J. C. (2006). Contabilidade Empresarial: A Contabilidade como Instrumento de Análise, Gerência e Decisão. as Demonstrações Contábeos:Origens e Finalidades. Os Aspectos Fiscais e Contábeis das Leis em Vigor (12 ${ }^{\mathrm{a}}$ ed.). São Paulo: Atlas.

Marriott, N., \& Marriott, P. (2000). Professional accountants and the development of a management accounting service for the small firm: barriers and possibilities. Management Accounting Research, 11(4), pp. 475-492.

MERCOSUL, M. C. (1998). Resolução nº 59.

Miranda, L. C., Libonati, J. J., \& Freire, D. R. (2008). Demanda por Serviços Contábeis pelos Mercadinhos: são os Contadores Necessários? Contabilidade Vista \& Revista, 19(1), 131-151.

Miranda, L. C., Libonati, J. J., Freire, D. R., \& Saturnino, O. (2008). Demanda por Serviços Contábeis pelos Mercadinhos : são os Contadores Necessários ? Contabilidade Vista \& Revista, 19(1), 131-151.

Moreira, R. D., Encarnação, L. V., Bispo Neto, O. A., Angotti, M., \& Colauto, R. D. (2013). A importância da informação contábil no processo de tomada de decisão nas micro e pequenas empresas. Revista Contemporânea de Contabilidade, 10(19), 119-140.

Padula, A. D. (abril/junho de 1996). Diversificação estratégica das atividades dos profissionais contábeis. Revista de Administração, 31(2), 29-39.

Raifur, L. (2013). Tese de Doutorado apresentada ao Departamento de Administração da FEA. Fatores Determinantes do Desempenho de Pequenas e Médias Empresas da Região Centro-Sul do Estado do Paraná. São Paulo: Universidade de São Paulo.

Relvas, T. R., Bertholini, A., \& Segato, V. D. (2010). Manual de Técnicas e Práticas de Aplicação da Lei 11.638/07 nas Pequenas e Médias Empresas. São Paulo: Conselho Regional de Contabilidade de São Paulo CRCSP.

Riva, E. D. (2013). Adoção do Padrão Internacional de Contabilidade nas Pequenas e Médias Empresas e seus Efeitos na Concessão de Crédito. Dissertação de Mestrado. São Paulo, Universidade de São Paulo: Faculdade de Economia, Administração e Contabilidade (FEA-USP).

Robson, P. J., \& Bennett, R. J. (2000). SME growth: the relationship with business advice and external collaboration. Small Business Economics, 15, 193-208. 
Rosa, J. A., \& Olinquevitch, J. L. (2005). De Contador a Consultor: Estratégias para ampliação do portifólio de serviços do escritório contábil. São Paulo: IOB Thomson.

Saldaña, J. (2013). The Coding Manual for Qualitative Researchers . Londres: Sage.

Schein, E. H. (1972). Consultoria de procedimentos. São Paulo: Edgard Blucher.

Schein, E. H. (1995). Process consultation, action research and clinical inquiry: are they the same? Journal of Managerial Psychology, 10(6), pp. 14-19.

SEBRAE. (5 de Outubro de 2010). Aumentar participação no PIB é desafio para micro e pequenas empresas da América Latina e Caribe. Acesso em 11 de Novembro de 2014, disponível em Agência Sebrae de Notícias (ASN): http://www.pr.agenciasebrae.com.br/sites/asn/uf/PR/Aumentarparticipa $\% \mathrm{C} 3 \% \mathrm{~A} 7 \% \mathrm{C} 3 \% \mathrm{~A} 30-$ no-PIB-\%C3\%A9-desafio-para-micro-e-pequenasempresas-da-Am\%C3\%A9rica-Latina-e-Caribe

SEBRAE, $\&$ CFC. (s.d.). http://www.comunidade.sebrae.com.br/contabilizando/Sobre $+o+$ Contabilizando/defa ult.aspx. Acesso em 05 de 12 de 2013, disponível em Contabilizando.

SEBRAE, S. B. (2007). Fatores Condicionantes e Taxas de Sobrevivência e Mortalidade das Micro e Pequenas Empresas no Brasil 2003-2005. Brasília: SEBRAE.

SEBRAE, S. B. (2013). Anuário do Trabalho na Micro e Pequena Empresa 2013. São Paulo: DIEESE.

SEBRAE, S. B. (2013). Sobrevivência das Empresas no Brasil - Coleção Estudos e Pesquisas. Brasília, DF: SEBRAE.

SEBRAE, S. B. (2014). Participação das Micro e Pequenas Empresas na Economia Brasileira. Brasília: SEBRAE.

Silva, A. C., \& Marion, J. C. (2013). Manual de Contabilidade para Pequenas e Médias Empresas. São Paulo: Atlas.

Stone, G. (2011a). Let's talk: Adapting accountants' communications to small business managers' objectives and preferences. Accounting, Auditing \& Accountability Journal,, 24(6), 781-809.

Stone, G. (2011b). Readability of accountants' communications with small business-Some business-Some Australian evidence. Accounting Forum, 35, pp. 247-261.

Stone, G. (2012). The effectiveness of newsletters in accountants' client relations with small business managers: An Australian qualitative study. Qualitative Research in Accounting and Management, 9(1), pp. 21-49.

The World Bank. (2014). Doing Business 2014:Understanding Regulations for Small and Medium-Size Enterprises. The World Bank. 
Trindade, M. A., Nunes, M. B., Linhares, T. d., \& Teixeira, R. M. (2010). Gestão do Capital de Giro em Micro e Pequenas Empresas. RACE - Revista de Administração, Contabilidade e Economia, 9(1-2), 231-250.

Ueno, R. B., \& Casa Nova, S. P. (2006). Um Estudo Sobre A Percepção do Micro e Pequeno Empresário Sobre A Importância da Contabilidade no Processo de Tomada de Decisão. Anais do IX SemeAd.

Vetter, S., \& Köhler, J. (2014). Business demographics and dynamics in Europe: Trends in the composition of the company landscape. Frankfurt: Deutsche Bank AG.

Villa, P. (2012). O monólogo contábil: uma análise do uso da contabilidade gerencial em micro e pequenas empresas à luz do processo comunicacional segundo Bakhtin. Dissertação Mestrado em Ciências Contábeis. Curitiba, PR: Programa de Mestrado em Contabilidade, Setor de Ciências Sociais Aplicadas, Universidade Federal do Paraná.

Villa, P., Espejo, M. M., Casa Nova, S. P., \& Voese, S. B. (2013). O Monólogo Contábil: uma Análise do Uso da Contabilidade Gerencial em Micro e Pequenas Empresas à luz do Processo Comunicacional segundo Bakhtin. Congresso Anpcont - Associação Nacional dos Programas de Pós-Graduação em Ciências Contábeis, (pp. 1-19).

Vox Populi. (2007). Fatores condicionantes e taxa de mortalidade das MPE São Paulo. São Paulo: SEBRAE-SP. 


\section{Apêndice 1}

(Termo de Consentimento Livre e Esclarecido assinado pelos entrevistados)

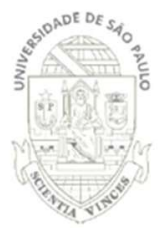

UNIVERSIDADE DE SÃO PAULO FACULDADE DE ECONOMIA, ADMINISTRACÃO E CONTABILIDADE DEPARTAMENTO DE CONTABILIDÁDE E ATUARIA

\section{Termo de Consentimento Livre e Esclarecido}

Título do estudo: Contadores consultores das Micro e Pequenas Empresas e suas habilidades e competências na visão de empresários e especialistas. (provisório)

Pesquisadora responsável: Cíntia do Nascimento Silva

Instituição / Departamento: Faculdade de Economia, Administração e Contabilidade - FEA USP / Departamento de Contabilidade.

Endereço da pesquisadora responsável: Avenida Prof. Luciano Gualberto, 908 - FEA 3 Sala 15 - Cidade Universitária - 05508-900 - São Paulo, SP - Brasil.

Telefone da pesquisadora responsável para contato: (11) 99129-7116

\section{Local da coleta de dados:}

Prezado (a) Senhor(a):

- Você está sendo convidado (a) a participar desta pesquisa de forma totalmente voluntária;

- Antes de concordar em participar desta pesquisa é muito importante que você compreenda as informações contidas neste documento;

- A pesquisadora deverá responder a todas as suas dúvidas antes que você decida participar;

- Você tem o direito de desistir de participar da pesquisa a qualquer momento, sem nenhuma penalidade e sem perder os benefícios aos quais tenha direito.

Objetivo do estudo: Esta pesquisa busca levantar as características da consultoria a ser oferecida pelo contador-consultor em sua atuação com as Micro e Pequenas Empresas - MPE na percepção de especialistas que atuam com esse tipo de empresa e dos próprios empreendedores/empresários.

Sua participação na pesquisa é importante e atende as seguintes condições:

Procedimentos. Sua participação nesta pesquisa consistirá em participar de uma entrevista que será gravada. A entrevista será transcrita e você terá acesso à transcrição parcial (dos trechos que serão citados na pesquisa) ou completa, caso prefira. 
Benefícios. Esta pesquisa trará maior conhecimento sobre o tema abordado, sem benefício direto para você, mas com contribuição para a discussão do assunto.

Riscos. A entrevista não representará qualquer risco de ordem física ou psicológica para você. Sigilo. As informações fornecidas por você terão sua privacidade garantida pelos pesquisadores responsáveis. Os sujeitos da pesquisa não serão identificados em nenhum momento, mesmo quando os resultados desta pesquisa forem divulgados em qualquer forma.

Utilização das informações. As informações fornecidas por você serão utilizadas somente para o desenvolvimento de pesquisas acadêmicas, incluindo a dissertação de mestrado da pesquisadora e artigos em eventos ou periódicos acadêmicos que se originem da pesquisa.

\section{Ciência e de acordo do participante (sujeito da pesquisa)}

Ciente e de acordo com o que foi anteriormente exposto, eu, , estou de acordo em participar desta pesquisa, assinando este consentimento em duas vias, ficando com a posse de uma delas.

São Paulo, de de 201X.

Assinatura do sujeito de pesquisa

Representante legal (para casos de pacientes menores de 18 anos, analfabetos, semianalfabetos ou portadores de deficiência auditiva ou visual)

\section{Ciência da pesquisadora responsável pelo projeto:}

Declaro que obtive de forma apropriada e voluntária o Consentimento Livre e Esclarecido deste sujeito de pesquisa ou representante legal para a participação neste estudo.

São Paulo, de de 201X
Cíntia do Nascimento Silva
Responsável pelo projeto




\section{Apêndice 2}

\section{Nome do nó}

Codificação Inicial

A Academia contábil tem que acompanhar as mudanças e ensinar a nova contabilidade

A busca pela sobrevivência como dificultador para implantar ferramentas de gestão

A concorrência com marcas famosas e consolidadas

A contabilidade para a tomada de decisão não precisa se limitar a técnicas de partidas dobradas

A contabilidade societária da PME é pouco exposta a usuário externo e pouco útil para esse público

A empresa como laboratório de aprendizado

A empresa é bem maior do que o contábil está dizendo, isso prejudica análise de crédito

A empresa é reflexo do seu administrador

A empresa se confunde com o perfil do seu administrador

A informalidade como realidade da MPE

A linguagem técnica é mais dura.

A maioria dos clientes só procuram suporte quando tem problema

A maioria dos PAPNs mata um leão por dia, não está preocupada com consultoria

A personalidade do Gestor interfere diretamente no perfil da empresa

A proximidade do contador ou administrado no negócio faz o apoio ser mais eficaz que de outras instituições de fomento da gestão, como SEBRAE, p.e.

A responsabilidade é do administrador, se fizer algo errado, o problema é dele

A universidade indo ao encontro do empresário da PE

Acha que a mudança de endereço deveria ser possível ser feita por ela, sem precisar de contador

Acha que assim como ela, muita gente não tem clareza do que o contador precisa fazer Acha que talvez seja pequena demais e daí venha o desinteresse do contador Aconselhamento para ter um subproduto vendável enquanto desenvolve seu produto principal

Adaptabilidade ao mercado como fator de fortalecimento da empresa

Adequação da linguagem e pistas visuais

Adequação da linguagem em papel consultivo

Adequar nomenclatura de contas contábeis para facilitar entendimento do cliente

Administração ao lado da contabilidade

Administração de egos na sociedade

Administrador é um cargo, pode ser sócio ou não

Administradores que misturam contas pessoais com empresariais

Agente financeiro considera histórico da relação com a empresa e suas garantias para avaliar crédito

Agente financeiro do BNDES é cobrado para disponibilizar instrumentos financeiros para a vida da $P E$

Ainda está buscando uma rotina desde o nascimento do filho

Ainda não pensaram como planejarão

Ajuda do contador em informações sobre impostos e folha de pagamento

Ajuda empreendedores a desenvolver seus planos de negócio

Ajuda empreendedores a estruturar a ideia de negócio e a captar recursos financeiros

Quant.

Quant.

Fontes Referências 


\section{Nome do nó}

\section{Codificacão Inicial}

Ajuda empresas a implementar programas de inovação e forma professores

Ajudou a desenvolver o SBplan com SEBRAE e FIESP, primeiro software gratuito para plano de negócios

Ajuste da informação à moeda funcional utilizado pelo PAPN, nem sempre é em reais

Além da ajuda fiscal e societária, ajudar o empresário a pensar estratégias diferenciais e gestão

Além da parte tributária, contador deveria orientar para contabilidade gerencial

Além das questões de registro patrimonial, contador deve orientar para a regularidade da PE em vários âmbitos

Alertando o cliente que ameaça mudar para mais barato sobre se o novo contador fará escrita contábil

Alguns conhecimentos contábeis são necessários para fazer o Plano de Negócios

Alguns PAPNs preferem manter-se no SIMPLES por acreditarem ser menos

fiscalizados e punidos, mesmo quando o lucro real seria mais vantajoso

Alta mortalidade das empresas no segmento de alimentação

Altas taxas para captação de capital de giro, parcelas pesadas

Alternativa para simples não ser fator limitador de crescimento seria um regime de transição

Aluno não sai da faculdade preparado para demonstrar ao cliente quanto seu serviço é importante

Amadorismo na Gestão

Amadurecimento da gestão aumenta demanda por planejamento e questão gerencial

Amadurecimento da gestão aumenta importância da contabilidade

Amadurecimento da visão da empresária

Amadurecimento do empresário por busca de conhecimento na universidade

Ambiente brasileiro pouco favorável à PME

Ambiente de negócios brasileiro pouco favorável para as MPEs

Ambiente de negócios complexo para a PE

Amiga contadora dá dicas sobre formalização como MEI

Ampliação do quadro de funcionários do escritório contábil está limitada ao aumento do número de clientes

Análise de custo de oportunidade

Angustias sobre o futuro do negócio e necessidade de apoio financeiro e de gestão

Antecipou o lançamento de sua empresa por causa de uma oportunidade

Antes de estar no simples, negócio era inviável. Paga até hoje parcelamento de impostos

Antes de existir o simples, não tinha dinheiro para pagar os impostos

Ao contrário da crença, para ser competitiva a MPE tem que estar regular com impostos e funcionários

Ao empresário com perfil empreendedor: administrador, a consultoria vai além da contabilidade

Aparato do governo contra sonegação está mais eficiente

Apenas quem é obrigado exige contabilidade societária

Apesar da proposta do CPC separa contabilidade e fisco, na prática, continua-se

fazendo contabilidade para o fisco

Apesar da taxa de mortalidade, há PAPNs que constroem impérios

Apesar de ter sócia, lida sozinha com o dia a dia do negócio

Apesar do muito trabalho, ser empresária é satisfatório

Quant.

Fontes Referências

Nó

mantido

Focada?

\begin{tabular}{|l|l|}
\hline 1 & \\
1 &
\end{tabular}

1

Sim

$\operatorname{Sim}$

1

\begin{tabular}{l|l|l}
1 & 1 & Sim \\
1 & 1 & Sim
\end{tabular}

Sim

Sim

Sim

\begin{tabular}{l|l|l}
1 & 1 & Sim
\end{tabular}

1

Sim

Sim

Sim

Sim

Sim

Sim

Sim

Sim

Sim

Sim

Sim

Sim

Sim

Sim

Sim

Sim

Sim

Sim

Sim

Sim

Sim

Sim

Sim

Sim

Sim

Sim

Sim

Sim

Sim 


\section{Nome do nó}

Codificação Inicial

Apesar dos problemas, as MPEs vão para frente

Apoiadores dos empresários: empreendedores não tem experiência, são geralmente estudiosos do assunto

Apoiando na decisão de vendas por margem de lucro x volume x poder de barganha

Apoiando na visão estratégica do negócio

Apoio em infraestrutura, rede de computadores e segurança

Aprender com os erros

Aprendizado com erros e fracassos anteriores são usados no empreendimento atual

Aprendizado da faculdade diferente do que é feito para a PE

Apresentação de modelos de documentos e exemplo de planilhas

Aproveitar enquanto seu produto é inovador e tem margem maior, até ter que se aproximar da concorrência

Arquitetos buscando sociedade com administradores para se organizar

Arrendamento de carteira de clientes de escritório contábil

Arrendamento de carteira de clientes de escritório contábil como forma de manter renda mensal ao deixar a carreira

As dificuldades da PE são as mesmas de outros tempos

As IFRS ainda demorarão a fazer parte da realidade das pequenas empresas

As IFRS serão conhecidas quando os contadores forem formados dentro desse novo padrão

Assessoria ajuda a antecipar maturidade gestão

Assessoria contábil exige maior esforço intelectual

Assessoria contábil, um guia da empresa

Assessoria estratégica para as tendências de mercado

Assessoria: orientação para separação da PJ e PF

Atender o cliente não é problema, o problema é o cliente ir até o espaço

Atribui vontade de empreender à sua geração

Atuação ativa em feiras e eventos sobre empreendedorismos

Aumento de vendas: tamanho faz buscar assessoria

Ausência de conceitos em relatórios financeiros pelos PAPNs da veterinária

Ausência do básico para melhorar o negócio

Autuações fiscais forçaram a profissionalização da gestão

Avaliação de viabilidade de projetos e estratégia da empresa em uma postura mais consultiva

Avaliação para concessão de crédito a MPE é feita como se fosse para PF

Barreiras para abertura e regularização ambiental dificultam a vida do PAPN

Barreiras para procurar ajuda profissional externa

Boca a boca como divulgação do serviço contábil

Busca por equilíbrio entre o visto na universidade e a prática (Nós)

Buscar novas formas de fazer com que os empreendedores façam da forma correta

Buscar parceiros que supram as deficiências e limitações do empresário como saída

Buscou informações e apoio na internet e com amigos

Buscou o que precisava na internet, consegui respostas em fóruns, mas demoravam

Cálculo meio intuitivo para a formação do preço do serviço do escritório

Capacitação para atender o cliente do escritório contábil inclui aprender 100 por cento das atividades

Captando o problema com o cliente

Características da gestão de MPE tem peso cultural

\begin{tabular}{c|c}
$\begin{array}{c}\text { Quant. } \\
\text { Fontes }\end{array}$ & $\begin{array}{c}\text { Quant. } \\
\text { Referências }\end{array}$
\end{tabular}

Nó

mantido

na

Focada?

Sim

Sim

Sim

Sim

Sim

Sim

Sim

Sim

Sim

Sim

Sim

Sim

Sim

Sim

Sim

Sim

Sim

Sim

Sim

Sim

Sim

Sim

Sim

Sim

Sim

Sim

Sim

Sim

Sim

Sim

Sim

Sim

Sim

Sim

Sim

Sim

Sim

Sim

Sim

Sim

Sim

Sim 


\begin{tabular}{|c|c|c|c|}
\hline \multirow[b]{2}{*}{ Nome do nó } & \multicolumn{2}{|c|}{ Codificação Inicial } & \multirow[b]{2}{*}{$\begin{array}{c}\text { Nó } \\
\text { mantido } \\
\text { na } \\
\text { Focada? }\end{array}$} \\
\hline & $\begin{array}{l}\text { Quant. } \\
\text { Fontes }\end{array}$ & $\begin{array}{c}\text { Quant. } \\
\text { Referências }\end{array}$ & \\
\hline Carga tributária é alta e continuará sendo independente do partido político no poder & 1 & 1 & Sim \\
\hline Carinho por todos os contadores que teve até hoje, mas acha que nenhum deles serviu & 1 & 1 & Sim \\
\hline Cenário da PME é de recursos mais escassos & 1 & 1 & Sim \\
\hline Centralização do poder no dono e informalidade do processo de gestão & 1 & 1 & Sim \\
\hline Certidões para evitar erro & 1 & 1 & Sim \\
\hline CFC exigir educação continuada seria um avanço & 1 & 1 & $\operatorname{Sim}$ \\
\hline Choque das Autuações fiscais forçaram a profissionalização da gestão (Nós) & 1 & 1 & Sim \\
\hline $\begin{array}{l}\text { Ciclo vicioso não se organizou por falta de tempo e falta de tempo porque não se } \\
\text { organizou }\end{array}$ & 1 & 1 & Sim \\
\hline Círculo da mediocridade & 1 & 1 & $\operatorname{Sim}$ \\
\hline $\begin{array}{l}\text { Cliente afirma que se há aumento do trabalho para lhe atender, que se negocie } \\
\text { honorário em vez de dizer 'não dá' }\end{array}$ & 1 & 1 & Sim \\
\hline Cliente ameaçando mudar para escritório mais barato & 1 & 1 & Sim \\
\hline Cliente de consultoria veio por indicação de cliente do escritório contábil & 1 & 1 & Sim \\
\hline Cliente desabafa com consultor, é preciso puxar o foco & 1 & 1 & $\operatorname{Sim}$ \\
\hline $\begin{array}{l}\text { Cliente faz contabilidade da empresa, mas não quer que contador faça sua declaração } \\
\text { pessoal para que não conheça seu patrimônio pessoal }\end{array}$ & 1 & 1 & $\operatorname{Sim}$ \\
\hline Cliente grande é aquele que paga maior honorário & 1 & 1 & Sim \\
\hline Cliente maior se preocupa mais com a contabilidade, normalmente & 1 & 1 & Sim \\
\hline $\begin{array}{l}\text { Cliente não aceita aumento de honorários em função de aumento de obrigações } \\
\text { acessórias imposto pelo fisco }\end{array}$ & 1 & 1 & Sim \\
\hline $\begin{array}{l}\text { Cliente omite informação do contador por desconfiança, não quer que o contador } \\
\text { conheça os negócios por completo }\end{array}$ & 1 & 1 & $\operatorname{Sim}$ \\
\hline $\begin{array}{l}\text { Cliente omite informação do contador por tentativas de redução de faturamento e } \\
\text { tributos:sonegação tributárias }\end{array}$ & 1 & 1 & Sim \\
\hline Cliente paga por serviço mediano, contador entrega serviço mediano & 1 & 1 & Sim \\
\hline $\begin{array}{l}\text { Cliente que ameaça deixar o escritório caso contadora não aceite 'jeitinhos', pois outro } \\
\text { contador lhe fará }\end{array}$ & 1 & 1 & Sim \\
\hline Cliente que contrata consultoria preventiva tem mais nível de profissionalização & 1 & 2 & Sim \\
\hline $\begin{array}{l}\text { Cliente que omite informação do contador por achar que seu patrimônio será alvo de } \\
\text { litígio jurídico }\end{array}$ & 1 & 1 & Sim \\
\hline Cliente que passa por auditoria investe em consultoria preventiva & 1 & 1 & $\operatorname{Sim}$ \\
\hline Cliente que puderam mudar para o simples, pós universalização, estão felizes & 1 & 1 & Sim \\
\hline Cliente troca de serviço por falta de atenção do contador & 1 & 1 & Sim \\
\hline Clientes maiores recebem visitas mais frequentes & 1 & 1 & $\operatorname{Sim}$ \\
\hline Clientes omitem informações do contador & 1 & 1 & Sim \\
\hline $\begin{array}{l}\text { Clientes que abrem empresa sem ter perfil empreendedor acabam responsabilizando o } \\
\text { contador por coisas que não estão na alçada do profissional }\end{array}$ & 1 & 1 & Sim \\
\hline Clientes que atuam com licitações são propensos à contratação de serviço preventivo & 1 & 1 & Sim \\
\hline $\begin{array}{l}\text { Clientes que são de médio porte, mas fazem arranjos legais diversos para continuarem } \\
\text { no simples nacional }\end{array}$ & 1 & 1 & Sim \\
\hline Clientes têm conseguido ficar no mínimo positivo, mesmo pagando impostos certinho & 1 & 1 & Sim \\
\hline Com a maturidade, empreender passou a ter outro sentido e outras razões & 1 & 1 & Sim \\
\hline Com ampliação de tamanha, são necessários controles diferentes & 1 & 1 & $\operatorname{Sim}$ \\
\hline $\begin{array}{l}\text { Com as IFRS, na grande empresa, o contador é tão estratégico quanto outros } \\
\text { profissionais da empresa }\end{array}$ & 1 & 1 & Sim \\
\hline $\begin{array}{l}\text { Com declarações unificadas, contador teria mais tempo para cumprir seu papel e não } \\
\text { trabalhar para o fisco }\end{array}$ & 1 & 1 & Sim \\
\hline
\end{tabular}




\section{Nome do nó}

Codificação Inicial

Com negócio fraco, deixou de lado as rotinas de controle de fluxo de caixa

Com tanta obrigação acessória, tempo é fator limitante do escritório para oferecer outros serviços aos clientes

Com uma renda mensal fixa, poderia se dedicar à consultoria, apesar da sazonalidade de faturamento inicial

Começou a empreender ainda grávida e deu sequência após o nascimento do filho

Começou o negócio com dinheiro pessoal de rescisões, sem plano de negócios ou investidor

Como a formação em veterinária ajudou no serviço contábil desse segmento

Como aparecer em uma mídia de rede social saturada

Como autônomo, poderia perder, mas poderia ganhar bem mais também

Como empresa de arquitetura e não decoração, pode ampliar o escopo de clientes, inclusive licitações públicas

Como o conhecimento pode promover amadurecimento do empresário

Como o contador será capaz de vender soluções de negócios que ele mesmo não aplica em sua empresa contábil

Como o simples, a tributação está mais propícia ao pequeno negócio

Como presta serviço de organização administrativa, tem que ter seu negócio bem estruturado, como modelo

Comodidade para ambos, contador e cliente, ao não gerar:ler relatórios

Complexidade da legislação tributária atrapalha a vida do empresário

Complexidade da tributação e a dificuldade de ter segurança de que tudo está certo

Complexidade da tributação é quem mais atrapalha a vida do empresário

Complexidade das questões burocráticas eventualmente levam o empresário a desistir do negócio

Complexidade na legislação faz com que contador gaste muito tempo na sua interpretação, tempo que poderia ser usado na gestão

Complexidade natural de determinados assuntos desafiam a comunicação entre contador-consultor e PAPN

Comprometimento de patrimônio familiar para pagar dívidas da empresa

Comunicação com escritório muito boa, empresário sabe que serviços tem e com quem deve falar

Comunicação é algo bem diferente quando o alvo é a PME

Comunicação é ponto básico na lida com os empresários

Concorrência

Condução do negócio era orgânica, nada muito pensado.

Confiança do PAPN no contador para as questões fiscais

Conflito entre sócios do escritório

Conhecimento da técnica contábil não é suficiente para ajudar o PAPN

Conhecimento deficitário em gestão atrapalha o empresário

Conhecimento do mercado de atuação

Conhecimento técnico como segurança para começar o próprio negócio em contabilidade

Conhecimento técnico mais amplo levou à opção de expandir o leque de clientes para lucro real

Consciência de que quando sai do planejado, embora dê certo o trabalho, pode estar ganhando menos

Conscientização para relação custo-benefício dos detalhamentos nos relatórios

Conscientizar o empresário para a importância dos controles básicos para a empresa

\begin{tabular}{|c|c|}
\hline \multicolumn{2}{|c|}{ Codificação Inicial } \\
$\begin{array}{c}\text { Quant. } \\
\text { Fontes }\end{array}$ & $\begin{array}{c}\text { Quant. } \\
\text { Referências }\end{array}$ \\
\hline
\end{tabular}

Nó

mantido

na

Focada?

Sim

Sim

Sim

Sim

Sim

Sim

Sim

Sim

Sim

Sim

Sim

Sim

Sim

Sim

Sim

Sim

Sim

Sim

Sim

Sim

Sim

Sim

Sim

Sim

Sim

Sim

Sim

Sim

Sim

Sim

Sim

Sim

Sim

Sim

Sim

Sim 


\begin{tabular}{|c|c|c|c|}
\hline \multirow[b]{2}{*}{ Nome do nó } & \multicolumn{2}{|c|}{ Codificação Inicial } & \multirow[b]{2}{*}{$\begin{array}{c}\text { Nó } \\
\text { mantido } \\
\text { na } \\
\text { Focada? }\end{array}$} \\
\hline & $\begin{array}{l}\text { Quant. } \\
\text { Fontes }\end{array}$ & $\begin{array}{c}\text { Quant. } \\
\text { Referências }\end{array}$ & \\
\hline $\begin{array}{l}\text { Constituir a empresa, mas não abrir conta corrente e integralizar capital é um problema } \\
\text { comum em empresas que ainda não entraram em operação }\end{array}$ & 1 & 2 & Sim \\
\hline Consulta prévia a certidões como seleção dos novos clientes & 1 & 1 & $\operatorname{Sim}$ \\
\hline Consultor com formação e experiência em áreas administrativas & 1 & 1 & Sim \\
\hline Consultor com liberdade para dar respostas mais evasivas, 'veja bem' & 1 & 1 & Sim \\
\hline Consultor de TI com foco no produto e seu desenho no Plano de Negócios & 1 & 1 & Sim \\
\hline Consultor incentivando validação de entendimento com o Contador & 1 & 1 & $\operatorname{Sim}$ \\
\hline Consultor indica o que o empresário precisa esperar do contador & 1 & 1 & Sim \\
\hline $\begin{array}{l}\text { Consultor indicando onde a resposta a um problema pode ser encontrada, quem talvez a } \\
\text { tenha }\end{array}$ & 1 & 1 & Sim \\
\hline Consultor revisão estratégia da empresa e substituindo equipamentos de produção & 1 & 1 & $\operatorname{Sim}$ \\
\hline Consultoria ajudando a repensar o preço e estratégia de venda de produtos & 1 & 1 & $\operatorname{Sim}$ \\
\hline Consultoria coletiva como forma de viabilizar a contratação desse serviço pela PE & 1 & 1 & Sim \\
\hline Consultoria coletiva via entidades de classe e afins para ganhar economia de escala & 1 & 1 & Sim \\
\hline Consultoria contábil com foco na contabilidade gerencial & 1 & 1 & Sim \\
\hline $\begin{array}{l}\text { Consultoria contábil como ajuda a tomada de decisão não só contábil ou tributária, mas } \\
\text { também de mercado }\end{array}$ & 1 & 1 & $\operatorname{Sim}$ \\
\hline Consultoria contábil como orientação da administração financeira & 1 & 1 & Sim \\
\hline $\begin{array}{l}\text { Consultoria contábil de orientação para uso de sistemas informatizados para os } \\
\text { controles do negócio }\end{array}$ & 1 & 1 & Sim \\
\hline Consultoria contábil e satisfação pessoal do contador & 1 & 1 & $\operatorname{Sim}$ \\
\hline $\begin{array}{l}\text { Consultoria contábil envolve conhecimento técnico contábil e tributário e } \\
\text { conhecimento de mercado, tudo que possa afetar o futuro da empresa }\end{array}$ & 1 & 1 & Sim \\
\hline $\begin{array}{l}\text { Consultoria contábil exige conhecimento de questões do mercado que não são } \\
\text { contabilidade exatamente }\end{array}$ & 1 & 1 & Sim \\
\hline $\begin{array}{l}\text { Consultoria contábil exige conhecimento de questões do mercado, como concorrência, } \\
\text { aspectos financeiros e estratégia }\end{array}$ & 1 & 1 & Sim \\
\hline Consultoria contábil mais valorizada que serviço técnico & 1 & 2 & Sim \\
\hline Consultoria contábil não onera tanto ou reduz custo & 1 & 1 & Sim \\
\hline $\begin{array}{l}\text { Consultoria contábil oferece informações necessária e relevantes para a tomada de } \\
\text { decisão sobre rumos do negócio }\end{array}$ & 1 & 1 & Sim \\
\hline Consultoria contábil para apurar e entender a lucratividade real do negócio & 1 & 1 & Sim \\
\hline $\begin{array}{l}\text { Consultoria contábil sobre entendimento dos regimes tributários que impactam no } \\
\text { planejamento e custo das mercadorias }\end{array}$ & 1 & 1 & Sim \\
\hline $\begin{array}{l}\text { Consultoria contábil sobre implicações de custos, tributos e riscos de modelos de } \\
\text { negócios distintos }\end{array}$ & 1 & 1 & Sim \\
\hline Consultoria contábil sobre melhor arranjo societário para atuação no negócio & 1 & 1 & Sim \\
\hline $\begin{array}{l}\text { Consultoria contratada para levantar contabilidade real gerencial x Contabilidade } \\
\text { oficial sonegação }\end{array}$ & 1 & 1 & Sim \\
\hline Consultoria de treinamento e orientação para cliente ter informação contábil mais ágil & 1 & 1 & Sim \\
\hline Consultoria em marketing e comercialização & 1 & 1 & $\operatorname{Sim}$ \\
\hline Consultoria em multiáreas & 1 & 1 & Sim \\
\hline Consultoria em negócios internacionais & 1 & 1 & Sim \\
\hline Consultoria era mais efetiva quando havia interesse do empresário em se ajustar & 1 & 1 & Sim \\
\hline Consultoria estratégico, sugestões de rumos a seguir no negócio & 1 & 1 & $\operatorname{Sim}$ \\
\hline Consultoria iniciada por diagnóstico & 1 & 1 & Sim \\
\hline $\begin{array}{l}\text { Consultoria integrando recursos existentes da empresa, indicando a busca de recursos } \\
\text { fora para atingir o objetivo de ter a informação com qualidade e em menor tempo }\end{array}$ & 1 & 1 & Sim \\
\hline
\end{tabular}




\section{Nome do nó}

Codificação Inicial

Consultoria jurídica com plantões para atender e tirar dúvidas

Consultoria mostrando se o negócio é rentável

Consultoria na interface entre a área administrativa e contábil

Consultoria oferecida junto com a contabilidade por honorário incompatível levou a

repensar o modelo de contrato

Consultoria para investimento começava com correção de erros, contábeis e tributários

Consultoria para projetos de investimento

Consultoria para projetos de investimento, apontamento de erros para solução, maior

interesse do empresário

Consultoria que agregue valor a um custo pagável

Consultoria tecnológica com ajuda em processos de projetos para captação de recursos

FAPESP, CNPq etc.

Consultoria $\mathrm{X}$ contabilidade técnica

Consultou um contador que lhe passou preço sem dizer que serviço oferecia de contrapartida

Conta de chega, valor que minimiza custo tributário como base

Contabilidade com linguagem inacessível

Contabilidade como carreira mais cartesiana, mais travada

Contabilidade como forma de ganhar dinheiro

Contabilidade customizada, com informações mais mastigadas

Contabilidade deve ser olhada de maneira prospectiva e não retrospectiva

Contabilidade diferenciada e com linguagem acessível na PE

Contabilidade é mais útil quando não há sonegação

Contabilidade engloba a escrita fiscal, o planejamento tributário

Contabilidade envia relatório do que foi contabilizado

Contabilidade gerencial deve ser feita internamente com dedicação exclusiva: o próprio gestor

Contabilidade gerencial é a mais interessante para o PAPN

Contabilidade igual a terceirização

Contabilidade mais simples, que fale a língua do empresário

Contabilidade na MPE é uma conta de chegada

Contabilidade não é só débito e crédito, é conhecer das despesas e custos, saber o que

dá crédito tributário, projetar faturamento para o planejamento tributário

Contabilidade oficial sem serventia no contexto da sonegação, sugestão de utilização da contabilidade gerencial

Contabilidade oficial, feita para o fisco, não representa a realidade da empresa

Contabilidade orientada para controles fiscais obrigatórios é pouco útil para boa gestão

Contabilidade para atender critérios tributários ou com foco na redução da carga tributária

Contabilidade poderia ter ajudado no planejamento, nos planos de negócio e de investimento, em projeções

Contabilidade pouco avançou em dar tratamento diferenciado à $\mathrm{PE}$

Contabilidade que não reflete o investimento real e seu impacto na busca por investidor

Contabilidade societária como instrumento para justificar o lucro recebido na PF: sócio Contabilidade societária é feita independente da exigência do cliente por recomendação do CFC

\begin{tabular}{c|c} 
Quant. & $\begin{array}{c}\text { Quant. } \\
\text { Fontes }\end{array}$ \\
Referências
\end{tabular}

Nó

mantido

na

Focada?

Sim

Sim

Sim

Sim

Sim

Sim

Sim

Sim

Sim

Sim

Sim

Sim

Sim

Sim

Sim

Sim

Sim

Sim

Sim

Sim

Sim

Sim

Sim

Sim

Sim

Sim

Sim

$\mathrm{Sim}$

Sim

Sim

Sim

Sim

Sim

Sim

Sim

Sim 


\begin{tabular}{|c|c|c|c|}
\hline \multirow[b]{2}{*}{ Nome do nó } & \multicolumn{2}{|c|}{ Codificação Inicial } & \multirow[b]{2}{*}{$\begin{array}{c}\text { Nó } \\
\text { mantido } \\
\text { na } \\
\text { Focada? }\end{array}$} \\
\hline & $\begin{array}{l}\text { Quant. } \\
\text { Fontes }\end{array}$ & $\begin{array}{c}\text { Quant. } \\
\text { Referências }\end{array}$ & \\
\hline $\begin{array}{l}\text { Contabilidade societária na PE é utilizada para atender fornecedores e para bancos na } \\
\text { solicitação de crédito }\end{array}$ & 1 & 1 & Sim \\
\hline $\begin{array}{l}\text { Contabilidade societária na PE feita para a apuração de tributos e para balizar as } \\
\text { obrigações acessórias }\end{array}$ & 1 & 1 & Sim \\
\hline Contabilidade societária não é tão importante já que são poucos os usuários externos & 1 & 1 & $\operatorname{Sim}$ \\
\hline Contabilidade societária não é vista como importante para o PAPN & 1 & 1 & Sim \\
\hline Contabilidade societária, IFRS, não é necessária para a PE & 1 & 1 & Sim \\
\hline Contabilidade técnica continuará existido, é preciso gente que queira ficar nela & 2 & 2 & Sim \\
\hline Contabilidade técnica é mecânica & 1 & 1 & Sim \\
\hline $\begin{array}{l}\text { Contabilidade técnica tem remuneração incompatível com a responsabilidade atrelada, } \\
\text { consultoria opção }\end{array}$ & 1 & 1 & Sim \\
\hline $\begin{array}{l}\text { Contabilidade técnica, despachante de impostos e folha como desmotivante do } \\
\text { profissional }\end{array}$ & 1 & 1 & $\operatorname{Sim}$ \\
\hline $\begin{array}{l}\text { Contabilidade tem um controle diferente daquele, baseado em caixa, que a empresária } \\
\text { usa }\end{array}$ & 1 & 1 & Sim \\
\hline Contabilidade terceirizada como alternativa de redução de custos & 1 & 1 & Sim \\
\hline Contabilidade tributária passou a ser optativa na FEA & 1 & 1 & $\operatorname{Sim}$ \\
\hline Contabilidade vista como apuração de impostos e Folha de Pagamento & 1 & 1 & Sim \\
\hline $\begin{array}{l}\text { Contabilidade, como profissão regulamentada, dá oportunidade ao seu profissional de } \\
\text { ter uma empresa, de empreender }\end{array}$ & 1 & 1 & Sim \\
\hline Contabilista 'só' assina balanço & 1 & 1 & Sim \\
\hline Contador $=$ impostos a pagar & 1 & 1 & Sim \\
\hline $\begin{array}{l}\text { Contador acaba sendo um administrador das MPEs clientes, orientando e decidindo } \\
\text { pelo PAPN }\end{array}$ & 1 & 1 & Sim \\
\hline Contador acompanhando a PE, falando com o empresário 1 ou 2 vezes por semana & 1 & 1 & Sim \\
\hline Contador afirma que pedido do cliente é muito trabalhoso & 1 & 1 & Sim \\
\hline Contador ajuda dando suporte técnico nas questões burocráticas da empresa & 1 & 1 & $\operatorname{Sim}$ \\
\hline Contador ajudando a empresária a superar seus medos dos números & 1 & 1 & Sim \\
\hline Contador ajudando a pensar os números da empresa & 1 & 1 & Sim \\
\hline $\begin{array}{l}\text { Contador ajudando o empresário a encontrar soluções para enfrentar autuação da } \\
\text { fiscalização do trabalho }\end{array}$ & 1 & 1 & Sim \\
\hline Contador ajudaria por meio de relatórios adaptados à $\mathrm{PE}$ & 1 & 1 & $\operatorname{Sim}$ \\
\hline Contador ajudou na parte burocrática e na emissão de guias de impostos & 1 & 1 & Sim \\
\hline Contador antigo e seu 'pé atrás' com o surgimento do simples na década de 1990 & 1 & 1 & Sim \\
\hline Contador aprendeu a maior parte da sua rotina contábil na prática e não na graduação & 1 & 1 & Sim \\
\hline $\begin{array}{l}\text { Contador às vezes sabe que o cliente faz vendas sem nota, mas orienta para o correto } \\
\text { sempre }\end{array}$ & 1 & 1 & Sim \\
\hline Contador avisa, sugere caminhos, mas é o empresário quem decido ouvir ou não & 1 & 1 & Sim \\
\hline Contador avisou que se mudasse de regime tributário, aumentaria o honorário & 1 & 1 & Sim \\
\hline Contador buscou treinamento adicional para preparar-se & 1 & 1 & $\operatorname{Sim}$ \\
\hline Contador cobra honorário, mas não explica, não ajuda, não conversa & 1 & 1 & Sim \\
\hline $\begin{array}{l}\text { Contador com ajuda proativa, ajudando a planejar, a formar preço, a fazer orçamento, a } \\
\text { checar ganho dos produtos }\end{array}$ & 1 & 1 & Sim \\
\hline Contador como advogado da empresa & 1 & 1 & $\operatorname{Sim}$ \\
\hline Contador como alguém para assinar, não parece parceiro & 1 & 1 & Sim \\
\hline Contador como integrador, Consultor, Empresário e Fornecedor & 1 & 1 & Sim \\
\hline Contador como um entregador de guias, fator de desmotivação & 1 & 1 & $\operatorname{Sim}$ \\
\hline Contador como um 'mal necessário' a PE & 1 & 1 & Sim \\
\hline
\end{tabular}




\begin{tabular}{|c|c|c|c|}
\hline \multirow[b]{2}{*}{ Nome do nó } & \multicolumn{2}{|c|}{ Codificação Inicial } & \multirow[b]{2}{*}{$\begin{array}{c}\text { Nó } \\
\text { mantido } \\
\text { na } \\
\text { Focada? }\end{array}$} \\
\hline & $\begin{array}{l}\text { Quant. } \\
\text { Fontes }\end{array}$ & $\begin{array}{l}\text { Quant. } \\
\text { Referências }\end{array}$ & \\
\hline $\begin{array}{l}\text { Contador consultor ajuda o cliente a enxergar estrategicamente seu negócio, entender } \\
\text { seu balanço para ter direção sobre custos e preço }\end{array}$ & 1 & 1 & Sim \\
\hline Contador consultor nunca existiu & 1 & 1 & Sim \\
\hline Contador consultor teria papel similar ao do SEBRAE & 1 & 1 & Sim \\
\hline Contador consultor, um orientador dos negócios, além de contador tributário & 1 & 1 & Sim \\
\hline Contador conversando com o empresário, falando das saídas & 1 & 1 & $\operatorname{Sim}$ \\
\hline Contador correto, não permite que o cliente faça errado & 1 & 1 & Sim \\
\hline Contador cumpre tabela, mal entende o negócio do cliente & 1 & 1 & $\operatorname{Sim}$ \\
\hline Contador da MPE discutindo com o empresário o futuro, custo, preço e planejamento & 1 & 1 & Sim \\
\hline $\begin{array}{l}\text { Contador de MPE para gerar tributos contribuiu para o pouco status da categoria no } \\
\text { país }\end{array}$ & 1 & 1 & Sim \\
\hline Contador deve conhecer técnicas de administração, conhecer o mercado e o negócio & 1 & 1 & $\operatorname{Sim}$ \\
\hline $\begin{array}{l}\text { Contador deve mergulhar no negócio do PAPN, oferecer apoio gerencial e não ter uma } \\
\text { postura fiscalista, mas de parceiro }\end{array}$ & 1 & 1 & Sim \\
\hline Contador deve ser mais presente na vida das empresas & 1 & 1 & Sim \\
\hline Contador deveria ter conhecimento sobre funcionamento dos tributos & 1 & 1 & Sim \\
\hline $\begin{array}{l}\text { Contador disse só conseguir simular com base no passado, não conseguia fazer } \\
\text { projetiva }\end{array}$ & 1 & 1 & Sim \\
\hline $\begin{array}{l}\text { Contador domina a técnica contábil, mas não sabe vender seus benefícios, não é } \\
\text { preparado para isso na universidade }\end{array}$ & 1 & 1 & Sim \\
\hline $\begin{array}{l}\text { Contador é desmotivado para explicar impostos ao cliente pois esse não tem interesse } \\
\text { em saber }\end{array}$ & 1 & 1 & Sim \\
\hline $\begin{array}{l}\text { Contador é importante porque pode-se ter muito problema caso o empresário não faça } \\
\text { as coisas direito }\end{array}$ & 1 & 1 & Sim \\
\hline Contador e o contato com outros escritórios para compartilhar boas práticas e erros & 1 & 1 & Sim \\
\hline $\begin{array}{l}\text { Contador é um gestor de conhecimento que vai além da contabilidade, deve saber tudo } \\
\text { que envolve a atividade de seus clientes para conseguir suportá-los }\end{array}$ & 1 & 2 & Sim \\
\hline $\begin{array}{l}\text { Contador empreendedor tem negócio bem estruturado, segmentado, pessoal treinado e } \\
\text { com carreira }\end{array}$ & 1 & 1 & Sim \\
\hline Contador esclarece sobre a maturidade gestão & 1 & 1 & Sim \\
\hline Contador escolhei a área por falta de alternativas e seu pai já tinha escritório & 1 & 1 & Sim \\
\hline Contador especialista em segmentos, por exemplo, varejo & 1 & 1 & Sim \\
\hline $\begin{array}{l}\text { Contador está pronto para atuar no escritório quando tem domínio obrigações fiscais, } \\
\text { contábeis }\end{array}$ & 1 & 1 & Sim \\
\hline $\begin{array}{l}\text { Contador fez série de cálculos, concluiu benefício na troca de equipamentos, porém, } \\
\text { sem considerar a estratégia da empresa }\end{array}$ & 1 & 1 & Sim \\
\hline Contador habilidoso comercialmente, vende pacotes de serviços contábeis: módulos & 1 & 1 & Sim \\
\hline Contador igual a fazedor de guia & 1 & 1 & Sim \\
\hline Contador igual a rigor com o que é correto & 1 & 1 & Sim \\
\hline Contador igual a um fardo & 1 & 1 & Sim \\
\hline $\begin{array}{l}\text { Contador igual alguém que ajuda a equilibrar as finanças, a pensar preço e a fazer fluxo } \\
\text { de caixa }\end{array}$ & 1 & 1 & Sim \\
\hline Contador igual burocracia & 1 & 1 & Sim \\
\hline Contador igual caixa preta na relação empresa-governo & 1 & 1 & Sim \\
\hline $\begin{array}{l}\text { Contador insistia que seu negócio não poderia estar no simples, mas empresária } \\
\text { pesquisou e sozinha conseguiu o enquadramento }\end{array}$ & 1 & 1 & Sim \\
\hline $\begin{array}{l}\text { Contador insistiu que deveria abrir ME de decoração para evitar tantos impostos no } \\
\text { começo do negócio }\end{array}$ & 1 & 1 & Sim \\
\hline Contador interno contribuindo para implantação de contabilidade gerencial & 1 & 1 & Sim \\
\hline
\end{tabular}




\begin{tabular}{|c|c|c|c|}
\hline \multirow[b]{2}{*}{ Nome do nó } & \multicolumn{2}{|c|}{ Codificação Inicial } & \multirow[b]{2}{*}{$\begin{array}{c}\text { Nó } \\
\text { mantido } \\
\text { na } \\
\text { Focada? }\end{array}$} \\
\hline & $\begin{array}{l}\text { Quant. } \\
\text { Fontes }\end{array}$ & $\begin{array}{c}\text { Quant. } \\
\text { Referências }\end{array}$ & \\
\hline Contador interno para maior suporte, alguém que endente do negócio & 1 & 1 & Sim \\
\hline Contador já tem um padrão internacional a seguir para as pequenas empresas & 1 & 1 & $\operatorname{Sim}$ \\
\hline Contador já vivenciou os dois mundos, da grande e agora da PE & 1 & 1 & Sim \\
\hline Contador mais velho, perfil tradicional, mediação negócio - governo & 1 & 1 & Sim \\
\hline $\begin{array}{l}\text { Contador manda contabilidade fiscal, empresário está implementando contabilidade } \\
\text { gerencial }\end{array}$ & 1 & 1 & Sim \\
\hline Contador mantém canal de comunicação próximo e aberto com seus clientes & 1 & 1 & $\operatorname{Sim}$ \\
\hline Contador não conhece esses controles próprios e informais de seus clientes & 1 & 1 & Sim \\
\hline Contador não conhece os controles gerenciais existentes na empresa & 1 & 1 & Sim \\
\hline Contador não consegue atender cliente por limitação do sistema que usa & 1 & 1 & $\operatorname{Sim}$ \\
\hline Contador não deve submeter-se a maus clientes, ainda que necessite dos honorários. & 1 & 1 & Sim \\
\hline $\begin{array}{l}\text { Contador não é contratado para ajudar a planejar o futuro, é contratado para atender } \\
\text { obrigação legal }\end{array}$ & 1 & 1 & Sim \\
\hline Contador não é formado para negociação & 1 & 1 & Sim \\
\hline Contador não é opção comum para consultas sobre planejamento & 1 & 1 & $\operatorname{Sim}$ \\
\hline Contador não empreendedor tem escritório desorganizado e complicado & 1 & 1 & Sim \\
\hline Contador não está preparado para vender seu serviço & 1 & 1 & Sim \\
\hline Contador não parceiro & 1 & 1 & Sim \\
\hline $\begin{array}{l}\text { Contador não participou do plano de negócios porque não foi chamado e nem se } \\
\text { disponibilizou }\end{array}$ & 1 & 1 & Sim \\
\hline Contador não poderia dar respostas evasivas como o consultor & 1 & 1 & Sim \\
\hline Contador não sabe demonstrar os benefícios da contabilidade & 1 & 1 & Sim \\
\hline Contador não sabe mostrar em que seu serviço é importante & 1 & 1 & $\operatorname{Sim}$ \\
\hline Contador não sabia a razão para o enquadramento tributário da empresa & 1 & 1 & $\operatorname{Sim}$ \\
\hline $\begin{array}{l}\text { Contador não sabia informar sobre a mudança na lei do simples, afirmou que seria a } \\
\text { mesma coisa }\end{array}$ & 1 & 1 & Sim \\
\hline Contador no escritório faz contabilidade de MPE para atender fisco & 1 & 1 & $\operatorname{Sim}$ \\
\hline Contador oferecendo alternativas e esclarecendo os riscos envolvidos & 1 & 1 & Sim \\
\hline Contador ofereceu cursos aos seus clientes & 1 & 1 & Sim \\
\hline $\begin{array}{l}\text { Contador ofereceu simulação de tributação retroativa para mudança de regime } \\
\text { tributário, após questionamentos do cliente }\end{array}$ & 1 & 1 & Sim \\
\hline $\begin{array}{l}\text { Contador orienta, conversa, senta junto para construir os controles de contabilidade } \\
\text { gerencial, mas é o cliente quem mantém o sistema }\end{array}$ & 1 & 1 & Sim \\
\hline Contador ou tem conhecimento, ou está fora do mercado & 1 & 1 & Sim \\
\hline $\begin{array}{l}\text { Contador parceiro igual aquele que ajuda a fazer o gerenciamento, mesmo em negócios } \\
\text { bem pequenos }\end{array}$ & 1 & 1 & Sim \\
\hline $\begin{array}{l}\text { Contador passivo, respondia rápido às perguntas, mas nunca oferecia alternativas de } \\
\text { forma proativa }\end{array}$ & 1 & 4 & $\operatorname{Sim}$ \\
\hline Contador pode ajudar & 1 & 1 & Sim \\
\hline Contador pode ajudar fornecendo informação & 1 & 1 & Sim \\
\hline $\begin{array}{l}\text { Contador pode ajudar na desburocratização das rotinas para que o PAPN consiga mais } \\
\text { tempo para cuidar do negócio }\end{array}$ & 1 & 1 & Sim \\
\hline $\begin{array}{l}\text { Contador pode ajudar o Empresário a planejar e prospectar o futuro, prever e preparar- } \\
\text { se para situações de longo prazo e, assim, se preparar contra fatores externos }\end{array}$ & 1 & 1 & Sim \\
\hline $\begin{array}{l}\text { Contador pode ajudar o PAPN a profissionalizar a gestão, o problema é mudar a bronca } \\
\text { que o empresário tem da contabilidade dos formulários fiscais }\end{array}$ & 1 & 1 & Sim \\
\hline Contador pode transformar os números em IFRS em demonstrações e orientar o cliente & 1 & 1 & Sim \\
\hline
\end{tabular}




\begin{tabular}{|c|c|c|c|}
\hline \multirow[b]{2}{*}{ Nome do nó } & \multicolumn{2}{|c|}{ Codificação Inicial } & \multirow[b]{2}{*}{$\begin{array}{c}\text { Nó } \\
\text { mantido } \\
\text { na } \\
\text { Focada? }\end{array}$} \\
\hline & $\begin{array}{l}\text { Quant. } \\
\text { Fontes }\end{array}$ & $\begin{array}{c}\text { Quant. } \\
\text { Referências }\end{array}$ & \\
\hline $\begin{array}{l}\text { Contador poderia ajudar a melhor o enquadramento fiscal da empresa para reduzir } \\
\text { custo tributário }\end{array}$ & 1 & 1 & Sim \\
\hline Contador poderia orientar sobre possibilidades legais e regimes tributários & 1 & 1 & Sim \\
\hline Contador precisa considerar a perspectiva da realidade do PAPN ao ajudá-lo & 1 & 1 & Sim \\
\hline Contador precisa desenvolver habilidades de administração & 1 & 1 & Sim \\
\hline $\begin{array}{l}\text { Contador precisa estudar bastante e manter-se atualizado com a legislação para apoiar o } \\
\text { cliente }\end{array}$ & 1 & 1 & Sim \\
\hline $\begin{array}{l}\text { Contador precisa ser proativo no treinamento do PAPN, explicar quando algum } \\
\text { documento está sendo enviado errado, p.e. }\end{array}$ & 1 & 1 & $\operatorname{Sim}$ \\
\hline Contador precisando descobrir informações. Empresário usa o chutômetro & 1 & 1 & Sim \\
\hline $\begin{array}{l}\text { Contador preocupação com a ética, suas orientações tributárias são dentro do que a lei } \\
\text { permite }\end{array}$ & 1 & 1 & $\operatorname{Sim}$ \\
\hline Contador preocupado em ressaltar idoneidade tributária de sua e de seus clientes & 1 & 1 & Sim \\
\hline $\begin{array}{l}\text { Contador quando propõe um controle informatizado, procura considerar controles } \\
\text { próprios do cliente para ver como o sistema poderá ajudar }\end{array}$ & 1 & 1 & Sim \\
\hline Contador que acredite no potencial do negócio & 1 & 1 & Sim \\
\hline Contador que ajude a analisar o negócio, sua viabilidade, seus custos e receitas & 1 & 1 & Sim \\
\hline Contador que ajude na gestão, que fizesse o empresário pensar na gestão & 1 & 1 & $\operatorname{Sim}$ \\
\hline Contador que apresente algumas soluções & 1 & 1 & Sim \\
\hline Contador que embolsava crédito tributário do empresário: falta de ética & 1 & 1 & Sim \\
\hline Contador que fala a minha língua & 1 & 1 & Sim \\
\hline Contador responde que seu sistema não faz contabilidade gerencial & 1 & 2 & Sim \\
\hline $\begin{array}{l}\text { Contador restrito a atendimento fiscal e societário: falta de preparo ou lógica do } \\
\text { mercado? }\end{array}$ & 1 & 1 & Sim \\
\hline $\begin{array}{l}\text { Contador se precaveu com cartas de responsabilidade do Administrador nas } \\
\text { informações fornecidas ao escritório contábil }\end{array}$ & 1 & 1 & Sim \\
\hline Contador sem informação sobre se o salário de sua equipe está dentro do mercado & 1 & 1 & Sim \\
\hline Contador sempre tenta chamar o cliente para o escritório a fim de explicar assuntos & 1 & 1 & $\operatorname{Sim}$ \\
\hline Contador só botava os contras & 1 & 1 & Sim \\
\hline Contador também é responsável pela empresa & 1 & 1 & Sim \\
\hline $\begin{array}{l}\text { Contador tem condição de orientar na implementação das ferramentas gerenciais, mas } \\
\text { não de manter o sistema atualizado }\end{array}$ & 1 & 1 & Sim \\
\hline Contador tem dificuldade para vender seus serviços & 1 & 1 & Sim \\
\hline $\begin{array}{l}\text { Contador tem perfil para ajudar o PAPN na gestão e o empresário tem confiança nesse } \\
\text { profissional }\end{array}$ & 1 & 1 & Sim \\
\hline Contador tem que conhecer o contexto do negócio e a história da empresa & 1 & 1 & Sim \\
\hline $\begin{array}{l}\text { Contador tem que tomar muito cuidado para não errar, dada a complexidade das } \\
\text { normas tributária }\end{array}$ & 1 & 1 & Sim \\
\hline Contador tem situação favorecida para poder ajudar o empresário em suas dificuldades & 1 & 1 & Sim \\
\hline Contador tem sua ética colocada à prova em muitas ocasiões & 1 & 1 & Sim \\
\hline Contador tentava insistir no amadurecimento do PAPN em relação à gestão & 1 & 1 & Sim \\
\hline $\begin{array}{l}\text { Contador teve treinamento adicional quando trabalhos em uma grande empresa de } \\
\text { consultoria }\end{array}$ & 1 & 1 & Sim \\
\hline Contador trabalha mais para o fisco que para o cliente & 1 & 2 & $\operatorname{Sim}$ \\
\hline $\begin{array}{l}\text { Contador tradicional, aquele dos formulários fiscais, é visto como inimigo do } \\
\text { empresário, }\end{array}$ & 1 & 1 & Sim \\
\hline Contador utiliza linguagem complicada para o empresário & 1 & 1 & Sim \\
\hline Contador vê o potencial do negócio e ajuda a ajeitar as finanças & 1 & 1 & Sim \\
\hline
\end{tabular}




\begin{tabular}{|c|c|c|c|}
\hline \multirow[b]{2}{*}{ Nome do nó } & \multicolumn{2}{|c|}{ Codificação Inicial } & \multirow[b]{2}{*}{$\begin{array}{c}\text { Nó } \\
\text { mantido } \\
\text { na } \\
\text { Focada? }\end{array}$} \\
\hline & $\begin{array}{l}\text { Quant. } \\
\text { Fontes }\end{array}$ & $\begin{array}{l}\text { Quant. } \\
\text { Referências }\end{array}$ & \\
\hline $\begin{array}{l}\text { Contador visto como quem mais atrapalha do que ajuda, alguém que põe sempre } \\
\text { empecilhos }\end{array}$ & 1 & 1 & Sim \\
\hline $\begin{array}{l}\text { Contador, ao acompanhar o dia a dia do negócio, conhece as dificuldades do negócio e } \\
\text { oferece informações focadas nisso }\end{array}$ & 1 & 1 & Sim \\
\hline Contador, escritório contábil, visto pelo PAPN como olho do governo na sua empresa & 1 & 1 & Sim \\
\hline $\begin{array}{l}\text { Contador, filho de pai contador e proprietário de escritório com experiência em Big } \\
\text { Four }\end{array}$ & 1 & 1 & Sim \\
\hline Contador, na consultoria, atua na área da Administração & 1 & 1 & Sim \\
\hline Contador, também como empreendedor, cresce quando seu cliente cresce & 1 & 1 & Sim \\
\hline $\begin{array}{l}\text { Contadora acaba assumindo o papel de gestora do negócio do cliente, 'indo além' da } \\
\text { sua função }\end{array}$ & 1 & 1 & Sim \\
\hline $\begin{array}{l}\text { Contadora ajudando com indicação do que precisava ser adequado para profissionalizar } \\
\text { a administração }\end{array}$ & 1 & 1 & Sim \\
\hline $\begin{array}{l}\text { Contadora assumiu modelo de contrato do ex-dono em que a consultoria estava inclusa } \\
\text { no honorário mensal }\end{array}$ & 1 & 1 & Sim \\
\hline Contadora com vontade de oferecer maior apoio aos clientes & 1 & 1 & Sim \\
\hline $\begin{array}{l}\text { Contadora disse que disponibilizaria planilhas se empresária precisasse, mas não } \\
\text { deixou claro do que se tratava }\end{array}$ & 1 & 1 & Sim \\
\hline Contadora é sócia única em seu escritório & 1 & 1 & Sim \\
\hline Contadora ficou feliz com o resultado da organização do trabalho & 1 & 1 & Sim \\
\hline $\begin{array}{l}\text { Contadora investindo na ampliação de seu escritório e incentivando a formação de seus } \\
\text { funcionários }\end{array}$ & 1 & 1 & Sim \\
\hline Contadora mais aberta ao diálogo & 1 & 1 & Sim \\
\hline Contadora não participou da criação dos controles internos vigentes na empresa & 1 & 1 & Sim \\
\hline Contadora oferece consultoria a seus clientes sem cobrança adicional & 1 & 1 & Sim \\
\hline $\begin{array}{l}\text { Contadora orienta o cliente para o que a lei permite, mas, apesar da sua } \\
\text { responsabilidade solidária, a decisão final é do cliente }\end{array}$ & 1 & 1 & Sim \\
\hline Contadora se importava, incentivava, motivava, dava suporte & 1 & 1 & Sim \\
\hline $\begin{array}{l}\text { Contadora tem política de valorização de equipe e contratação de gente qualificada ou } \\
\text { disposta a se qualificar }\end{array}$ & 1 & 1 & Sim \\
\hline $\begin{array}{l}\text { Contadora tem política de valorização de seus funcionários, não tem condição de pagar } \\
\text { melhores salários, por isso, não contrata mais gente, apesar de precisar }\end{array}$ & 1 & 1 & Sim \\
\hline $\begin{array}{l}\text { Contadora tomou gosto pela contabilidade no escritório e tomava iniciativa para } \\
\text { aprender mais }\end{array}$ & 1 & 1 & Sim \\
\hline $\begin{array}{l}\text { Contadora trouxe familiares para seu escritório por razões de confiança e para ajudar a } \\
\text { família }\end{array}$ & 1 & 1 & Sim \\
\hline Contadora valoriza funcionários, quer que eles cresçam junto com seu escritório & 1 & 1 & Sim \\
\hline Contadora vê sua carteira de clientes como ainda pequena & 1 & 1 & Sim \\
\hline $\begin{array}{l}\text { Contadora, entendendo a fase difícil do negócio da empresária, tem atendido com o } \\
\text { mínimo sem cobrar }\end{array}$ & 1 & 1 & Sim \\
\hline Contadores ainda tem a mentalidade de preenchedores de impostos. & 1 & 1 & Sim \\
\hline $\begin{array}{l}\text { Contadores ficariam desestimulados ao tratar com clientes sem experiência em } \\
\text { administração }\end{array}$ & 1 & 1 & Sim \\
\hline $\begin{array}{l}\text { Contadores formados pela FEA procuram escritórios para serviços técnicos que não } \\
\text { sabem fazer }\end{array}$ & 1 & 1 & Sim \\
\hline Contadores outsiders do negócio & 1 & 1 & $\operatorname{Sim}$ \\
\hline $\begin{array}{l}\text { Contadores que erraram e não quiseram assumir a responsabilidade, motivo para troca } \\
\text { de profissional }\end{array}$ & 1 & 1 & Sim \\
\hline
\end{tabular}


Nome do nó

Codificação Inicial

Contadores sem domínio do negócio do cliente, emissores de guias e cada vez mais caros

Contato com a PE por meio dos casos trazidos pelos alunos

Contato do BNDES com PMEs ocorre via parceiros, bancos comerciais

Contato do contador para falar de impostos e Folha de Pagamento

Contato indireto com $\mathrm{PE}$ via alunos

Contato pessoal permite captar pistas visuais sobre entendimento ou não do que se fala

Contato Universidade-Empresários

Continuidade das métricas como referência para comparação

Contou com ajuda de seus orientadores da pós-graduação e de seus amigos, sem pagar por isso

Contou com algumas aulas de administração na graduação em gastronomia

Contraprestação de serviços do governo como desmotivador para recolhimento dos impostos reais

Contrataria um contador, caso não fosse MEI, por ser obrigada a fazê-lo

Contribuir para a transformação do empresário de 'em formação' para 'empresário' propriamente dito

Controla os projetos em suas planilhas para ação preventiva. A partir da DRE, atua depois da ocorrência

Controle de caixa básico

Controle de pagamento de frequência de alunos e pagamentos de professores

Controle de qualidade igual a acompanhamento de certidões negativas

Controle financeiro básico feito em planilha Excel

Controle no começo era mais simplório, com crescimento, usa-se ferramenta

Controles de custos rudimentares, foi abandonando um controle informatizado,

planilha eletrônica

Controles internos ainda precisam ser aprimorados para ratear despesas gerais

Controles vão melhorando à medida que a empresa vai crescendo

Crédito BNDES para quem passar elo crivo do agente financeiro, análise de crédito

Crença do PAPN de que para ter sucesso, tem que sonegar

Crescimento faz buscar assessoria

Crescimento faz buscar sistemas e financiamentos

Crescimento traz demandas mais complexas ao contador

Criação de um canal de comunicação

Crise econômica chega logo em seu mercado de atuação, a arquitetura

Crítica à recente universalização do simples nacional

Cuidado para o uso de termos técnicos contábeis

Cuidados na conscientização para não o empresário não se sentir ofendido

Cultura da sonegação

Cultura de não regularizar funcionário como imprescindível para ir para frente

Cultura entre empresário de que o Simples é melhor

Curso da FEA é para SA, não é para escritório contábil

Curso de direito na FGV como exemplo de nova estratégia de ensino que prepara para além do habitual

Curso de graduação fraco em Santos

Curso de graduação privado um pouco mais voltado a impostos

Curso iniciado, mas não concluído de administração antes de formar-se contador

\begin{tabular}{|c|c|c|}
\hline \multicolumn{2}{|c|}{ Codificação Inicial } & \multirow[b]{2}{*}{$\begin{array}{c}\text { Nó } \\
\text { mantido } \\
\text { na } \\
\text { Focada? }\end{array}$} \\
\hline $\begin{array}{l}\text { Quant. } \\
\text { Fontes }\end{array}$ & $\begin{array}{c}\text { Quant. } \\
\text { Referências }\end{array}$ & \\
\hline 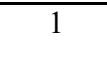 & 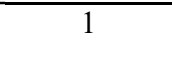 & Sim \\
\hline 1 & 1 & $\mathrm{Sim}$ \\
\hline 1 & 1 & Sim \\
\hline 1 & 1 & Sim \\
\hline 1 & 2 & Sim \\
\hline 1 & 1 & Sim \\
\hline 1 & 2 & Sim \\
\hline 1 & 1 & Sim \\
\hline 1 & 1 & Sim \\
\hline 1 & 1 & Sim \\
\hline 1 & 1 & Sim \\
\hline 1 & 1 & Sim \\
\hline 1 & 1 & Sim \\
\hline 1 & 1 & Sim \\
\hline 1 & 1 & Sim \\
\hline 1 & 1 & Sim \\
\hline 1 & 1 & Sim \\
\hline 1 & 1 & Sim \\
\hline 1 & 1 & Sim \\
\hline 1 & 1 & Sim \\
\hline 1 & 1 & $\mathrm{Sim}$ \\
\hline 1 & 1 & Sim \\
\hline 1 & 1 & Sim \\
\hline 1 & 1 & $\mathrm{Sim}$ \\
\hline 1 & 1 & Sim \\
\hline 1 & 1 & Sim \\
\hline 1 & 1 & Sim \\
\hline 1 & 1 & Sim \\
\hline 1 & 1 & Sim \\
\hline 1 & 1 & Sim \\
\hline 1 & 1 & $\mathrm{Sim}$ \\
\hline 1 & 1 & $\mathrm{Sim}$ \\
\hline 1 & 2 & $\mathrm{Sim}$ \\
\hline 1 & 1 & $\mathrm{Sim}$ \\
\hline 1 & 1 & Sim \\
\hline 1 & 1 & $\mathrm{Sim}$ \\
\hline 1 & 1 & Sim \\
\hline 1 & 1 & $\mathrm{Sim}$ \\
\hline 1 & 1 & $\mathrm{Sim}$ \\
\hline 1 & 1 & $\mathrm{Sim}$ \\
\hline
\end{tabular}




\begin{tabular}{|c|c|c|c|}
\hline \multirow[b]{2}{*}{ Nome do nó } & \multicolumn{2}{|c|}{ Codificação Inicial } & \multirow[b]{2}{*}{$\begin{array}{c}\text { Nó } \\
\text { mantido } \\
\text { na } \\
\text { Focada? }\end{array}$} \\
\hline & $\begin{array}{l}\text { Quant. } \\
\text { Fontes }\end{array}$ & $\begin{array}{c}\text { Quant. } \\
\text { Referências }\end{array}$ & \\
\hline $\begin{array}{l}\text { Dada a complexidade das obrigações acessórias, os erros são comuns e as punições } \\
\text { cruéis }\end{array}$ & 1 & 1 & Sim \\
\hline Definição de ME & 1 & 2 & $\operatorname{Sim}$ \\
\hline Definição de MPE do SEBRAE e da RFB & 1 & 1 & Sim \\
\hline Definição de MPME do BNDES & 1 & 1 & Sim \\
\hline Demora para liberação de recursos FAPESP PIP & 1 & 1 & Sim \\
\hline Departamentalização para apuração de custos e margens & 1 & 2 & Sim \\
\hline Departamento pessoal, definição & 1 & 1 & Sim \\
\hline Depois de captar clientes, escritório contábil não revisou seus critérios e metas & 1 & 1 & $\operatorname{Sim}$ \\
\hline $\begin{array}{l}\text { Depois de quebrada a barreira da resistência, PAPN passa a ver valor no orçamento } \\
\text { prospectivo }\end{array}$ & 1 & 1 & Sim \\
\hline $\begin{array}{l}\text { Depois do filho, voltou a trabalhar em escritórios e mantém sua empresa apenas para } \\
\text { trabalhos menores como freelancer }\end{array}$ & 1 & 1 & Sim \\
\hline $\begin{array}{l}\text { Depreciação fiscal confundida como depreciação contábil, por isso, pouco útil para } \\
\text { gestão }\end{array}$ & 1 & 1 & Sim \\
\hline Desânimo ao fazer retrospectiva de seu negócio & 1 & 1 & $\operatorname{Sim}$ \\
\hline Desatenção aos princípios da entidade e competência & 1 & 1 & $\operatorname{Sim}$ \\
\hline Desatenção com a Regularidade ambiental na PE & 1 & 1 & Sim \\
\hline Desconfiança para abrir informações & 1 & 1 & Sim \\
\hline Desconforto quando acaba cobrando menos que o escritório anterior & 1 & 1 & Sim \\
\hline $\begin{array}{l}\text { Desconstruindo a ideia de que a carga do negócio é idêntica àquela informada pelo } \\
\text { IBPT }\end{array}$ & 1 & 1 & Sim \\
\hline Descontentamento da Empresária com o Contador & 1 & 1 & Sim \\
\hline $\begin{array}{l}\text { Desigualdade de tratamento para empresas pequenas e para as grandes, grandes têm } \\
\text { benefícios onde o pequeno tem barreira }\end{array}$ & 1 & 1 & Sim \\
\hline $\begin{array}{l}\text { Desilusão em bancos, mais bagagem adquirida em escritório levou-a a decisão de } \\
\text { empreender em contabilidade }\end{array}$ & 1 & 1 & Sim \\
\hline Desinteresse em certas disciplinas FEA, como perícia contábil & 1 & 1 & Sim \\
\hline Desmotivação com a diferença entre o visto na universidade e a prática & 1 & 1 & Sim \\
\hline Desmotivação na passagem de informações ao novo contador & 1 & 1 & Sim \\
\hline Destrinchando os departamentos do PE & 1 & 1 & Sim \\
\hline Dia a dia da empresária & 1 & 1 & Sim \\
\hline Diferença de gerações de contadores e o tempo de adaptação às novas demandas & 1 & 1 & Sim \\
\hline Diferença entre gestão financeira e contabilidade como razão para não usar a última & 1 & 1 & Sim \\
\hline Diferenças de geração no perfil da gestão. & 1 & 1 & Sim \\
\hline $\begin{array}{l}\text { Diferenças muito grandes entre um regime tributário e outros: MEI X Simples X } \\
\text { Presumido X Real }\end{array}$ & 1 & 1 & Sim \\
\hline Diferenças na definição de porte & 1 & 1 & Sim \\
\hline $\begin{array}{l}\text { Dificuldade da incubadora para ajudar um grande número de empresa tendo uma } \\
\text { estrutura pequena }\end{array}$ & 1 & 1 & Sim \\
\hline Dificuldade de ajudar o PAPN sem noções básicas de negócios, ADM e contabilidade & 1 & 1 & Sim \\
\hline Dificuldade de apurar valor pago ao escritório anterior & 1 & 1 & Sim \\
\hline Dificuldade de comunicação entre empresário e contador & 1 & 1 & Sim \\
\hline Dificuldade de dar conta de tudo quando o negócio começa a crescer & 1 & 1 & Sim \\
\hline $\begin{array}{l}\text { Dificuldade de domínio de práticas gestão: saber por projetar Fluxo de Caixa, entender } \\
\text { capital de giro e ponto de equilíbrio }\end{array}$ & 1 & 1 & Sim \\
\hline Dificuldade de equilibrar custo $\mathrm{X}$ equipe $\mathrm{X}$ preço dado pelo mercado & 1 & 1 & Sim \\
\hline Dificuldade de lidar com sócios diferentes num projeto comum & 1 & 1 & Sim \\
\hline
\end{tabular}




\section{Nome do nó}

\section{Codificação Inicial}

Dificuldade de saber quando para de incrementar seu produto

Dificuldade de ser fazer conhecida

Dificuldade do consultor em tratar de assuntos de negócios, quando precisa antes ensinar conceitos básicos, como caixa e competência

Dificuldade do contador em responder questões que não são sua especialidade ou estão além da sua capacidade de infraestrutura

Dificuldade em atender a demanda do mercado por falta de equipe

Dificuldade em pensar o futuro: imediatismo empresarial

Dificuldade em se adequar ao novo cenário mercadológico e às novas demandas

Dificuldade em ver a empresa como um outro organismo

Dificuldade na divulgação do negócio em saber o que deve ser feito melhor

Dificuldade para dividir as tarefas do espaço entre as sócias, uma fica mais sobrecarregada

Dificuldade para elaborar relatório simples de conciliação caixa x competência

Dificuldade para entender competência x preferência por caixa

Dificuldade para fazer plano de negócios porque não tem facilidade com números

Dificuldade para o contador terceirizado fazer contabilidade gerencial, o ideal seria que o próprio gestor a fizesse

Dificuldade para o escritório chegar ao cliente, conseguir cliente

Dificuldade para seguir o plano, ainda que o plano informal, da cabeça

Dificuldades do empresário em atender demandas normativas, tributárias, trabalhistas e ambientais

Dificuldades dos empresários com negócios bem pequenos no entendimento de termos contábeis simples

Dificuldades para administrar o pouco recurso da Incubadora e oferecer consultoria a um número grande de empresas

Dilema do honorário contábil: empresário acha muito, contador acha pouco

Discorda da postura pedagógica sobre o PAPN, de ter que ensiná-lo

Discutindo a carga tributária com o cliente Contador X empresário

Disponibilização da informação de forma gratuita e pela internet

Divisão gerencial-societária é mais acadêmica, para o empresário é tudo a mesma coisa

Domínio da metodologia contábil não basta, é preciso ter visão de negócio, se especializar num segmento

Dosagem adequada do consultor no incentivo a controles no momento inicial da vida do negócio

Duração das parcerias: sociedades no negócio

DVA com relatório informacional para a ME

E novas obrigações acessórias vão surgindo, como o e-social

É preciso esperar o negócio maturar, ter paciência, principalmente no começo

É preciso grana para mudar de endereço, algo que deveria ser feito pela internet de forma simples

EBTs de médio porte e já estabelecidas têm de se preocupar com todos os detalhes jurídicos, tributários e contábeis

EBTs incubadas precisam preparar-se para encontrar investidores

EBTs passam longo tempo inicial sem faturamento, contador busca regime que facilita seu trabalho nesse período

Eficácia do apoio do contador depende da confiança e tempo de relacionamento

Elaboração de projetos econômico-financeiros para captação de recursos

\begin{tabular}{l|c} 
Quant. & $\begin{array}{c}\text { Quant. } \\
\text { Fontesências }\end{array}$ \\
\hline
\end{tabular}

\begin{tabular}{|l|l|}
\hline 1 & \\
1 & 1 \\
\end{tabular}

\begin{tabular}{l|l}
\hline 1 & \\
1 & \\
1 &
\end{tabular}




\begin{tabular}{|c|c|c|c|}
\hline \multirow[b]{2}{*}{ Nome do nó } & \multicolumn{2}{|c|}{ Codificação Inicial } & \multirow[b]{2}{*}{$\begin{array}{c}\text { Nó } \\
\text { mantido } \\
\text { na } \\
\text { Focada? }\end{array}$} \\
\hline & $\begin{array}{l}\text { Quant. } \\
\text { Fontes }\end{array}$ & $\begin{array}{l}\text { Quant. } \\
\text { Referências }\end{array}$ & \\
\hline Em que consistiria a consultoria contábil & 1 & 2 & Sim \\
\hline Emissão de NF decoração como depreciativo para seu currículo & 1 & 1 & Sim \\
\hline Empatia do empresário da veterinária com o Contador-Veterinário & 1 & 2 & Sim \\
\hline Empatia na comunicação com o empresário & 1 & 1 & Sim \\
\hline $\begin{array}{l}\text { Empreendedor com plano de negócios e viabilidade deveria ter mais facilidades para } \\
\text { acesso ao crédito para investimento }\end{array}$ & 1 & 1 & Sim \\
\hline Empreendedor é alguém que tem coragem & 1 & 1 & Sim \\
\hline Empreendedor é um solitário & 1 & 1 & Sim \\
\hline Empreendedor faz do negócio uma empresa com vida & 1 & 1 & Sim \\
\hline Empreendedor inova, busca melhorias contínuas & 1 & 2 & $\operatorname{Sim}$ \\
\hline Empreendedor nato, vontade de construir coisas & 1 & 1 & Sim \\
\hline Empreendedor por oportunidade & 1 & 1 & Sim \\
\hline $\begin{array}{l}\text { Empreendedor tem senso de autonomia, assume responsabilidades e riscos, lidera } \\
\text { pessoas e se comunica }\end{array}$ & 1 & 1 & Sim \\
\hline Empreendedor X PAPN & 1 & 2 & Sim \\
\hline $\begin{array}{l}\text { Empreendedora fez muita pesquisa prévia na internet para ter certeza de tudo que seria } \\
\text { necessário para a abertura do negócio }\end{array}$ & 1 & 1 & $\operatorname{Sim}$ \\
\hline $\begin{array}{l}\text { Empreendedores que procuram o contador antes de abrir um negócio para orientação } \\
\text { prévia }\end{array}$ & 1 & 1 & Sim \\
\hline $\begin{array}{l}\text { Empreendedores que procuram o contador para ter as noções iniciais do que é } \\
\text { necessário para ter empresa, sem qualquer planejamento prévio do negócio }\end{array}$ & 1 & 1 & Sim \\
\hline Empreendedorismo diretamente ligado ao fracasso e ao sucesso. & 1 & 1 & Sim \\
\hline Empreendedorismo é da pessoa, não da profissão & 1 & 1 & Sim \\
\hline Empreender como alternativa para equilibrar tempo entre trabalho, família e prazer & 1 & 1 & $\operatorname{Sim}$ \\
\hline Empreender como oportunidade de buscar satisfação pessoal & 1 & 1 & Sim \\
\hline Empreender é resolver problemas & 1 & 1 & Sim \\
\hline Empreender sem conhecimento e preparo é empreender na porra-louquice & 1 & 1 & $\operatorname{Sim}$ \\
\hline Empreendimento anterior relegado a hobby & 1 & 1 & Sim \\
\hline $\begin{array}{l}\text { Empresa anterior não prosperou por problemas com os sócios: Canibalização de } \\
\text { negócios }\end{array}$ & 1 & 1 & Sim \\
\hline Empresa exigiu contabilidade gerencial do seu contador & 1 & 1 & Sim \\
\hline Empresa grande tem contador interno. Público alvo da consultoria contábil seria MPE & 1 & 1 & $\operatorname{Sim}$ \\
\hline Empresa jovem, contador acessório & 1 & 1 & Sim \\
\hline Empresa jovem, empresário faz-tudo & 1 & 1 & Sim \\
\hline Empresa maior tem maior acesso a incentivos governamentais e a linhas de crédito & 1 & 1 & Sim \\
\hline Empresa maior tem uma visão diferente da contabilidade & 1 & 1 & Sim \\
\hline $\begin{array}{l}\text { Empresária acha que a questão do bebê é uma particularidade sua, pois suas sócias ou } \\
\text { têm filhos maiores ou têm com quem deixá-los }\end{array}$ & 1 & 1 & Sim \\
\hline $\begin{array}{l}\text { Empresária acredita na qualidade e potencial de seu serviço e espera reerguer o negócio } \\
\text { apesar da crise pela qual passa }\end{array}$ & 1 & 1 & Sim \\
\hline $\begin{array}{l}\text { Empresária alegou ao contador incompatibilidade dos ganhos com o honorário do } \\
\text { serviço contábil }\end{array}$ & 1 & 1 & Sim \\
\hline Empresária com formação em comunicação & 1 & 1 & Sim \\
\hline Empresária com formação em jornalismo, em seu segundo negócio & 1 & 1 & Sim \\
\hline Empresária conseguiu enquadra a própria empresa no simples & 1 & 1 & Sim \\
\hline Empresária considera-se realista, pé no chão & 1 & 1 & Sim \\
\hline $\begin{array}{l}\text { Empresária em dificuldade tem consciência da importância da gestão, administração e } \\
\text { planejamento do negócio }\end{array}$ & 1 & 1 & Sim \\
\hline
\end{tabular}




\section{Nome do nó}

\section{Codificação Inicial}

Empresária especializada em gestão de negócios alimentícios

Empresária faz balanço e diz que faltou estruturar seu negócio

Empresária fica sobrecarregada com todas as atividades do negócio, então, não consegue controlar as horas por projeto

Empresária lembra do começo duro tal como seu recomeço atual

Empresária não entende como organizar seu caixa, como bancar empresa em momentos de pouca receita

Empresária não procurou ajuda externa para melhorar sua gestão

Empresária não usa relatório contábil por entender que não corresponde à realidade do seu negócio

Empresária pediu demonstrativo comparativo Simples X presumido para apoiar sua decisão, contador isso que não ia dar certo

Empresária pensando na conta que tem para pagar amanhã, em prospectar clientes Empresária repensa seu posicionamento no mercado, acredita que a saída esteja na especialização como diferencial, em ser referência

Empresária se auto define como criativa, alguém que gosta de criar, de ver seu negócio como especial

Empresária se sente perdida e não vê saída

Empresária sem rotinas administrativas

Empresária sente-se em um mambembismo

Empresária tenta fazer tudo certo

Empresária tentou chamar seu contador para conversas sobre ter uma empresa de arquitetura

Empresária vê problemas em como a lei é feito e nos órgãos de fiscalização Empresária vê que seus colegas de categoria compartilham dos mesmos problemas que ela

Empresária vê que sua classe não sabe gerir e nem como captar clientes

Empresárias assumem múltipla jornada: família, casa, empresa

Empresário aceita aumento de honorário do contador afirmando confiar no trabalho do profissional

Empresário acha que contador não é parceiro porque avalia relação honorário $\mathrm{X}$ custo

Empresário acha que é um dos poucos clientes que pede relatório regular, pois

demorou para que o escritório automatizasse isso

Empresário acha que paga muito ao contador e espera mais dele

Empresário acomodado não quer crescer, não busca informação adicional e não quer ajuda

Empresário acompanha relatórios contábeis mensalmente

Empresário às vezes já procura ajuda nervoso

Empresário às vezes procura outro profissional para aconselhamento em vez do contador

Empresário buscou falar com o contador sobre contabilidade gerencial, mas o profissional não se mostrou parceiro

Empresário com perfil empreendedor

Empresário com perfil empreendedor prevê mudanças, planeja-se e ajusta-se ao mercado

Empresário com perfil empreendedor sem formação em gestão, procurou SEBRAE, livros e consultoria

Empresário com perfil empreendedor, com mais estudo, procura contador para tirar dúvidas e usa informação para tomada de decisão

\begin{tabular}{|c|c|c|}
\hline \multicolumn{2}{|c|}{ Codificação Inicial } & \multirow[b]{2}{*}{$\begin{array}{c}\text { Nó } \\
\text { mantido } \\
\text { na } \\
\text { Focada? }\end{array}$} \\
\hline $\begin{array}{l}\text { Quant. } \\
\text { Fontes }\end{array}$ & $\begin{array}{c}\text { Quant. } \\
\text { Referências }\end{array}$ & \\
\hline 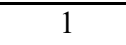 & 1 & $\mathrm{Sim}$ \\
\hline 1 & 1 & Sim \\
\hline 1 & 1 & Sim \\
\hline 1 & 1 & Sim \\
\hline 1 & 1 & Sim \\
\hline 1 & 1 & Sim \\
\hline 1 & 1 & Sim \\
\hline 1 & 1 & Sim \\
\hline 1 & 1 & Sim \\
\hline 1 & 1 & Sim \\
\hline 1 & 1 & Sim \\
\hline 1 & 1 & Sim \\
\hline 1 & 1 & Sim \\
\hline 1 & 1 & Sim \\
\hline 1 & 1 & Sim \\
\hline 1 & 2 & Sim \\
\hline 1 & 1 & Sim \\
\hline 1 & 1 & Sim \\
\hline 1 & 1 & Sim \\
\hline 1 & 1 & Sim \\
\hline 1 & 1 & Sim \\
\hline 1 & 1 & Sim \\
\hline 1 & 1 & Sim \\
\hline 1 & 1 & Sim \\
\hline 1 & 1 & Sim \\
\hline 1 & 1 & Sim \\
\hline 1 & 1 & Sim \\
\hline 1 & 1 & Sim \\
\hline 1 & 1 & Sim \\
\hline 1 & 1 & Sim \\
\hline 1 & 1 & Sim \\
\hline 1 & 1 & Sim \\
\hline 1 & 1 & Sim \\
\hline
\end{tabular}




\begin{tabular}{|c|c|c|c|}
\hline \multirow[b]{2}{*}{ Nome do nó } & \multicolumn{2}{|c|}{ Codificação Inicial } & \multirow[b]{2}{*}{$\begin{array}{c}\text { Nó } \\
\text { mantido } \\
\text { na } \\
\text { Focada? }\end{array}$} \\
\hline & $\begin{array}{l}\text { Quant. } \\
\text { Fontes }\end{array}$ & $\begin{array}{l}\text { Quant. } \\
\text { Referências }\end{array}$ & \\
\hline $\begin{array}{l}\text { Empresário com perfil não empreendedor vai dançando conforme a música, } \\
\text { preocupado com o curto prazo e não com a estratégia de longo prazo }\end{array}$ & 1 & 1 & Sim \\
\hline $\begin{array}{l}\text { Empresário com pouca capacitação para gestão, falta noção das demandas e obrigações } \\
\text { envolvidas em ter um negócio }\end{array}$ & 1 & 2 & Sim \\
\hline Empresário começa negócio sem preocupação em estabelecer controles & 1 & 1 & Sim \\
\hline Empresário começa seu empreendimento muito empolgado & 1 & 1 & Sim \\
\hline Empresário computando a carga tributária do Brasil X seu negócio & 1 & 1 & Sim \\
\hline $\begin{array}{l}\text { Empresário confia abrir informações quando sente que essas não serão usadas contra } \\
\text { eles }\end{array}$ & 1 & 1 & Sim \\
\hline Empresário contábil com preocupação em receber seus honorários & 1 & 1 & Sim \\
\hline Empresário contrata contador para calcular tributos e preencher obrigações acessórias & 1 & 2 & Sim \\
\hline $\begin{array}{l}\text { Empresário contrata profissional especializado normalmente para atender alguma } \\
\text { exigência normativa }\end{array}$ & 1 & 1 & Sim \\
\hline Empresário controla seu negócio por meio de planilhas & 1 & 1 & Sim \\
\hline Empresário curioso sobre questões de ordem tributária & 1 & 1 & Sim \\
\hline Empresário da PE como um pássaro ainda novinho doido para crescer e alçar voo & 1 & 1 & Sim \\
\hline $\begin{array}{l}\text { Empresário da PE como um pássaro ainda novinho que precisa de cuidados para se } \\
\text { desenvolver e voar }\end{array}$ & 1 & 1 & Sim \\
\hline Empresário da PE entende que se se profissionalizar, seu negócio melhora & 1 & 1 & Sim \\
\hline Empresário de longa data tem maior resistência à mudança & 1 & 1 & Sim \\
\hline Empresário desabafam com seus apoiadores & 1 & 1 & Sim \\
\hline Empresário desconfia do contador, acha que paga muito imposto & 1 & 1 & Sim \\
\hline Empresário é alguém que luta diariamente pela sobrevivência & 1 & 1 & Sim \\
\hline $\begin{array}{l}\text { Empresário empreendedor bem-sucedido, controla tudo e usa a contabilidade no seu } \\
\text { processo decisório }\end{array}$ & 1 & 1 & Sim \\
\hline Empresário empreendedor busca financiamento, especialização, quer crescer o negócio & 1 & 1 & Sim \\
\hline $\begin{array}{l}\text { Empresário empreendedor de sucesso que não tem formação, com baixo grau de } \\
\text { instrução formal }\end{array}$ & 1 & 1 & Sim \\
\hline Empresário empreendedor tem ouvido aberto, vai atrás da informação & 1 & 1 & $\operatorname{Sim}$ \\
\hline $\begin{array}{l}\text { Empresário enfrenta dificuldades ao lidar em mercados em que a corrupção é } \\
\text { institucionalizada }\end{array}$ & 1 & 1 & Sim \\
\hline Empresário entende do seu ramo técnico, mas não de gestão: Profissionalização & 1 & 1 & $\operatorname{Sim}$ \\
\hline Empresário fazia classificação por centro de custo, mas contabilidade não usava & 1 & 1 & Sim \\
\hline Empresário faz-tudo não vê contabilidade como muito relevante & 1 & 1 & Sim \\
\hline $\begin{array}{l}\text { Empresário ficou chocado em saber que sua classificação por centro de custo não era } \\
\text { usada }\end{array}$ & 1 & 1 & Sim \\
\hline $\begin{array}{l}\text { Empresário flexível consegue lidar melhor com aspectos externos que impactam sua } \\
\text { empresa }\end{array}$ & 1 & 1 & Sim \\
\hline $\begin{array}{l}\text { Empresário gosta do fato de seu contador, indiretamente, supervisionar o trabalho de } \\
\text { sua equipe }\end{array}$ & 1 & 1 & Sim \\
\hline Empresário imaturo segue modismos & 1 & 1 & Sim \\
\hline $\begin{array}{l}\text { Empresário já viu seus colegas se darem mal em fiscalização, quando achavam estar } \\
\text { tudo em ordem }\end{array}$ & 1 & 1 & Sim \\
\hline Empresário leva seu bebê para a empresa & 1 & 1 & Sim \\
\hline Empresário maduro planeja o retorno do investimento & 1 & 1 & Sim \\
\hline Empresário maduro vê o novo criticamente & 1 & 3 & Sim \\
\hline $\begin{array}{l}\text { Empresário muito envolvido com o dia a dia operacional tem dificuldade de lidar com } \\
\text { os fatores externos que impactam seu negócio }\end{array}$ & 1 & 1 & Sim \\
\hline
\end{tabular}




\section{Nome do nó}

\section{Codificação Inicial}

Empresário não empreendedor externaliza a culpa

Empresário não quer pagar mais honorários para mudar para o real, para ele isso é só cumprimento de legislação, não é benefício

Empresário não sabia que gestão de custos era gestão contábil

Empresário não sente segurança sobre se o contador faz tudo corretamente, embora ele procure fazer

Empresário não tem tempo para buscar a universidade

Empresário não utiliza contabilidade gerencial porque não a conhece, acaba não estudando a respeito

Empresário obrigado a implantar infraestrutura para emissão de NFe

Empresário pediu adaptações na DRE que recebia do contador

Empresário pediu explicação ao contador sobre funcionamento dos regimes tributários e passou a fazer as contas

Empresário pensa que contabilidade é só aquela da publicação do BP, desconhece a gerencial

Empresário pesquisou e buscou alternativas para redução de sua carga tributária

Empresário precisa ser alertado que seu regime simplificado é transitório

Empresário precisa ter confiança no consultor para abrir todos os detalhes da operação alvo da consulta, inclusive quando há problemas.

Empresário procura advogado para decidir e contador para executar

Empresário que não tem perfil empreendedor, que não se preocupa com a administração, não aproveita as oportunidades ou não busca ajuda quando o negócio não vai bem

Empresário que prefere seus controles próprios, no caderninho e isso é suficiente para ele

Empresário questionando o enquadramento fiscal da empresa. Por que presumido

Empresário reclamando do contador no SEBRAE

Empresário sem perfil empreendedor fica focado no dia a dia operacional e não quer cuidar da administração do negócio

Empresário tem controle por projetos

Empresário teme que suas informações sejam passadas para a concorrência

Empresário toma decisões com base em seus próprios relatórios, não utiliza contabilidade

Empresário vê a cara tributária como alta por cálculo intuitivo

Empresário, administrador de fato, é flexível e detecta antes problemas no mercado para se preparar

Empresário, já teve 2 empresas que fecharam, está em seu terceiro negócio

Empresários achavam suficiente o que sua contabilidade lhes oferecia

Empresários bem-sucedidos que não tinham gestão profissional quando seus negócios eram pequenos

Empresários buscam assessoria em familiares e amigos

Empresários com diferentes realidades e situação financeira

Empresários com perfil empreendedor buscam informação no contador para tomada de decisão porque confiam

Empresários com personalidade difícil desafiam os Contadores.

Empresários cometem erros deliberadamente e culpam o contador

Empresários conversam entre si, compartilham ideias e sugestões para redução de recolhimento de tributos

Empresários de EBTs têm muito conhecimento tecnológico, mas pouco de gestão

\begin{tabular}{|l|l|}
\hline \multicolumn{2}{|c|}{ Codificação Inicial } \\
\hline $\begin{array}{l}\text { Quant. } \\
\text { Fontes }\end{array}$ & $\begin{array}{c}\text { Quant. } \\
\text { Referências }\end{array}$ \\
\hline
\end{tabular}

Nó

mantido

na

Focada?

Sim

Sim

Sim

Sim

Sim

Sim

Sim

Sim

Sim

Sim

Sim

Sim

Sim

Sim

Sim

Sim

Sim

Sim

Sim

Sim

Sim

Sim

Sim

Sim

Sim

Sim

Sim

Sim

Sim

Sim Sim

Sim

$\operatorname{Sim}$ 


\begin{tabular}{|c|c|c|c|}
\hline \multirow[b]{2}{*}{ Nome do nó } & \multicolumn{2}{|c|}{ Codificação Inicial } & \multirow[b]{2}{*}{$\begin{array}{c}\text { Nó } \\
\text { mantido } \\
\text { na } \\
\text { Focada? }\end{array}$} \\
\hline & $\begin{array}{l}\text { Quant. } \\
\text { Fontes }\end{array}$ & $\begin{array}{c}\text { Quant. } \\
\text { Referências }\end{array}$ & \\
\hline Empresários de PE estão no nosso círculo & 1 & 1 & $\operatorname{Sim}$ \\
\hline $\begin{array}{l}\text { Empresários deixam de ser cuidados pelo Estado e passam a dividir a função de } \\
\text { cuidadores da população com ele }\end{array}$ & 1 & 1 & Sim \\
\hline Empresários focados no desenvolvimento do produto & 1 & 1 & Sim \\
\hline $\begin{array}{l}\text { Empresários lidam com situações em que propinas e lobistas, às vezes, são uma } \\
\text { realidade e interferem diretamente no negócio }\end{array}$ & 1 & 1 & Sim \\
\hline $\begin{array}{l}\text { Empresários mantêm rede de contato entre eles, se consultam sobre indicação de } \\
\text { trabalho de um contador }\end{array}$ & 1 & 1 & Sim \\
\hline Empresários não conhecem a lucratividade dos seus negócios & 1 & 1 & Sim \\
\hline Empresários não empreendedores contentam-se com contabilidade: despachante & 1 & 1 & Sim \\
\hline $\begin{array}{l}\text { Empresários não querem gastar mais do que poderiam, por isso, só contratam } \\
\text { especialistas quando são obrigados }\end{array}$ & 1 & 1 & Sim \\
\hline Empresários que assumem riscos trabalhistas sem considerar o impacto dessa decisão & 1 & 1 & Sim \\
\hline Empresários reclamam de pouco retorno financeiro dos negócios & 1 & 1 & Sim \\
\hline Empresários reclamam dos funcionários & 1 & 1 & Sim \\
\hline Empresários têm dificuldades para avaliar o negócio, se está rentável e viável & 1 & 1 & Sim \\
\hline Empresários têm que cuidar de coisas que não deveriam ser de suas alçadas & 1 & 1 & Sim \\
\hline $\begin{array}{l}\text { Empresas EBTs que estão no mercado estariam melhor se tivessem boa gestão adm- } \\
\text { financeira-contábil }\end{array}$ & 1 & 1 & Sim \\
\hline $\begin{array}{l}\text { Empresas familiares com gestão focada no dono não têm predisposição à consultoria } \\
\text { preventiva }\end{array}$ & 1 & 1 & Sim \\
\hline Empresas têm especificidades segundo seu porte, formato e momento: fase & 1 & 1 & Sim \\
\hline Endividamento após saída de principal cliente & 1 & 1 & Sim \\
\hline Enquadramento fiscal adequada para gerar economias & 1 & 1 & Sim \\
\hline Enquadramento fiscal adequado ao momento e particularidades do negócio & 1 & 1 & Sim \\
\hline $\begin{array}{l}\text { Enquadramento no simples na fase inicial sem movimento: Empresário precisa ser } \\
\text { alertado que em algum momento isso deverá ser revisto }\end{array}$ & 1 & 1 & Sim \\
\hline $\begin{array}{l}\text { Enquanto o contador estiver associado a questões societárias e fiscais, seu serviço será } \\
\text { subavaliado }\end{array}$ & 1 & 1 & Sim \\
\hline $\begin{array}{l}\text { Entendimento do perfil do sócio, do cliente. Há aqueles mais empreendedores e há } \\
\text { aqueles mais acomodados no negócio }\end{array}$ & 1 & 1 & Sim \\
\hline $\begin{array}{l}\text { Entrada na faculdade aumentou sua valorização pelo escritório contábil onde } \\
\text { trabalhava }\end{array}$ & 1 & 1 & Sim \\
\hline $\begin{array}{l}\text { Enxerga a opção de ter um sócio administrador como forma de superar sua limitação e } \\
\text { manter-se no operacional }\end{array}$ & 1 & 1 & Sim \\
\hline $\begin{array}{l}\text { Enxerga o escritório contábil ajudando no imediato, no que há para pagar hoje ou no } \\
\text { próximo mês }\end{array}$ & 1 & 1 & Sim \\
\hline $\begin{array}{l}\text { Equilibrar a exposição a exigências legais não significa indicar coisas totalmente } \\
\text { erradas que inviabilize o negócio }\end{array}$ & 1 & 1 & Sim \\
\hline Equilíbrio entre trabalho de casa com filho e Negócio & 1 & 1 & Sim \\
\hline Equipe despreparada gera improdutividade no escritório contábil & 1 & 1 & Não \\
\hline Erro fiscal como razão para a troca de contador & 1 & 1 & Não \\
\hline Erros nas obrigações acessórias como motivo de descontentamento com o contador & 1 & 1 & Não \\
\hline Escolha do contador pelo arquiteto ocorre por menor preço, diminuição do fardo. & 1 & 1 & Não \\
\hline $\begin{array}{l}\text { Escolha por contabilidade em função da preferência por números e indicadores } \\
\text { financeiros }\end{array}$ & 1 & 1 & Não \\
\hline Escrita contábil que ninguém pede, feita por exigência legal: distribuição de lucros & 1 & 1 & Não \\
\hline
\end{tabular}




\begin{tabular}{|c|c|c|c|}
\hline \multirow[b]{2}{*}{ Nome do nó } & \multicolumn{2}{|c|}{ Codificação Inicial } & \multirow[b]{2}{*}{$\begin{array}{c}\text { Nó } \\
\text { mantido } \\
\text { na } \\
\text { Focada? }\end{array}$} \\
\hline & $\begin{array}{l}\text { Quant. } \\
\text { Fontes }\end{array}$ & $\begin{array}{c}\text { Quant. } \\
\text { Referências }\end{array}$ & \\
\hline Escrita fiscal, definição & 1 & 1 & Não \\
\hline Escritório arca com prejuízo por preço mal feito, mal negociado & 1 & 1 & Não \\
\hline Escritório contábil ajudou a projeção de $n^{\circ}$ de funcionários, custo de mão de obra & 1 & 1 & Não \\
\hline Escritório contábil com 45 clientes & 1 & 1 & Não \\
\hline Escritório contábil com 60 anos, 120 empresas, sendo a metade de pequenos negócios & 1 & 1 & Não \\
\hline $\begin{array}{l}\text { Escritório contábil consegue clientes por indicação, isso é um reconhecimento do } \\
\text { trabalho, confiança }\end{array}$ & 1 & 1 & Não \\
\hline $\begin{array}{l}\text { Escritório contábil exige conhecimento da área contábil, levantamento de } \\
\text { demonstrações contábeis }\end{array}$ & 1 & 1 & Não \\
\hline $\begin{array}{l}\text { Escritório contábil exige conhecimento da área de pessoal, folha de pagamento, } \\
\text { declarações e apuração de encargos }\end{array}$ & 1 & 1 & Não \\
\hline $\begin{array}{l}\text { Escritório contábil exige conhecimento da área fiscal, apuração de impostos, } \\
\text { declarações e resolução de autos de infração }\end{array}$ & 1 & 1 & Não \\
\hline $\begin{array}{l}\text { Escritório contábil exige conhecimento em apurar todos os tributos do cliente, dar } \\
\text { suporte a suas perguntas }\end{array}$ & 1 & 1 & Não \\
\hline $\begin{array}{l}\text { Escritório contábil ministrando treinamentos próprios para completar formação } \\
\text { universitária de seus contadores }\end{array}$ & 1 & 1 & Não \\
\hline Escritório contábil valoriza pouco os funcionários, o que leva a alta rotatividade & 1 & 1 & Não \\
\hline $\begin{array}{l}\text { Escritório contábil, experiência cansativa, mas que permite estabelecer vínculos entre o } \\
\text { que se viu na universidade e a realidade prática }\end{array}$ & 1 & 1 & Não \\
\hline $\begin{array}{l}\text { Escritório de contabilidade com clientes que fazem mutretas, ou rompe contrato ou } \\
\text { avisa COAF }\end{array}$ & 1 & 1 & Não \\
\hline Escritório diferencia empresa pelo tamanho desforço demandado e não pelo porte em si & 1 & 1 & Não \\
\hline $\begin{array}{l}\text { Escritório e estratégias com equipe: bons salários X incorporar perspectiva de } \\
\text { rotatividade alta }\end{array}$ & 1 & 1 & Não \\
\hline Escritório herdado da família & 1 & 1 & Não \\
\hline Escritório não oferece contabilidade gerencial, faz apenas a societária & 1 & 1 & Não \\
\hline Escritório oferece contabilidade gerencial como produto da consultoria & 1 & 1 & Não \\
\hline $\begin{array}{l}\text { Escritório optou por dispensar clientes com práticas evasivas para preservar integridade } \\
\text { da empresa }\end{array}$ & 1 & 1 & Não \\
\hline $\begin{array}{l}\text { Escritório prioriza cumprir obrigações acessória e acaba não conseguindo atender na } \\
\text { esfera gerencial }\end{array}$ & 1 & 1 & Não \\
\hline $\begin{array}{l}\text { Escritório procura das o mesmo tratamento para todos os clientes, independente do } \\
\text { porte }\end{array}$ & 1 & 1 & Não \\
\hline $\begin{array}{l}\text { Escritório que não assume erros: multas geradas por ele causa descontentamento no } \\
\text { cliente }\end{array}$ & 1 & 1 & Não \\
\hline $\begin{array}{l}\text { Escritório tem muitos clientes, não consegue dar atenção se fosse contabilidade } \\
\text { gerencial }\end{array}$ & 1 & 1 & Não \\
\hline Especialista com experiência na concessão de financiamento a PME & 1 & 1 & Não \\
\hline Especialista conhece as dificuldades da pequena empresa & 1 & 1 & Não \\
\hline $\begin{array}{l}\text { Especialista em concessão de crédito trabalha com a perspectiva da realidade do } \\
\text { PAPN: com pouco tempo para planejar }\end{array}$ & 1 & 1 & Não \\
\hline $\begin{array}{l}\text { Especialista teve treinamento comportamental com intuito de desenvolver empatia com } \\
\text { o empresário }\end{array}$ & 1 & 1 & Não \\
\hline $\begin{array}{l}\text { Especialistas, Empresários e Contadores sobrepõem em suas falas os serviços de } \\
\text { despachante de folha e impostos ao serviço de contabilidade }\end{array}$ & 1 & 1 & Não \\
\hline Especialização do contador permite conhecer as nuances daquele mercado & 1 & 1 & Não \\
\hline Especialização X diversificação da carteira de clientes do escritório & 1 & 1 & Não \\
\hline Especificidade da especificidade no planejamento tributário & 1 & 1 & Não \\
\hline
\end{tabular}




\begin{tabular}{|c|c|c|c|}
\hline \multirow[b]{2}{*}{ Nome do nó } & \multicolumn{2}{|c|}{ Codificação Inicial } & \multirow[b]{2}{*}{$\begin{array}{c}\text { Nó } \\
\text { mantido } \\
\text { na } \\
\text { Focada? }\end{array}$} \\
\hline & $\begin{array}{l}\text { Quant. } \\
\text { Fontes }\end{array}$ & $\begin{array}{l}\text { Quant. } \\
\text { Referências }\end{array}$ & \\
\hline Especificidades do negócio X similaridades de necessidade de gestão & 1 & 1 & Não \\
\hline $\begin{array}{l}\text { Essa orientação dentro das IFRS dependerá da autopreparação e atualização do } \\
\text { contador }\end{array}$ & 1 & 1 & Não \\
\hline $\begin{array}{l}\text { Está sem contadora oficial no momento, conta com o apoio de uma que lhe 'quebra um } \\
\text { galho' }\end{array}$ & 1 & 1 & Não \\
\hline Estímulo ao Empresário para que leve suas dúvidas ao consultor & 1 & 1 & Não \\
\hline Estoque encalhado e o comprometimento do caixa e da sustentabilidade & 1 & 1 & Não \\
\hline $\begin{array}{l}\text { Estoque parado X dificuldade financeira e a proatividade do contador em levantar o } \\
\text { problema }\end{array}$ & 1 & 1 & Não \\
\hline Estratégia apoiado pelo feeling e não por medições & 1 & 1 & Não \\
\hline Estratégia de produtos e definição de clientela & 1 & 1 & Não \\
\hline Estratégia de vendas para clientes PJ & 1 & 1 & Não \\
\hline Estremecida da sócia & 1 & 1 & Não \\
\hline $\begin{array}{l}\text { Estudos sobre tributação podem levar a aumento da carga tributário e isso seria uma } \\
\text { razão para o Empresário omitir informação do contador }\end{array}$ & 1 & 1 & Não \\
\hline Ética do Contador tem peso na relação de confiança com o empresário & 1 & 1 & Não \\
\hline Ética na precificação do serviço ao assumir trabalho de outro escritório & 1 & 1 & Não \\
\hline $\begin{array}{l}\text { Excesso de atenção ao plano de negócios e de marketing do escritório contábil levou a } \\
\text { desatenção com a prospecção de mercado, a busca por cliente }\end{array}$ & 1 & 1 & Não \\
\hline Excesso de cumprimento de obrigação e burocracias como um problema para o PAPN & 1 & 1 & Não \\
\hline Excesso de declarações acessórias, um mercado de multas & 1 & 1 & Não \\
\hline Ex-contador que assume a responsabilidade por problemas de sua competência & 1 & 1 & Não \\
\hline Ex-contador que não assume problemas gerados em sua competência & 1 & 2 & Não \\
\hline $\begin{array}{l}\text { Existência de uma resistência grande dos PAPNs à qualificação da gestão por razões } \\
\text { culturais }\end{array}$ & 1 & 1 & Não \\
\hline Experiência anterior como empreendedora & 1 & 1 & Não \\
\hline Experiência com MPME em escritórios de contabilidade & 2 & 2 & Não \\
\hline Experiência com PE do Comércio, Turismo e Agronegócio & 1 & 1 & Não \\
\hline Experiência com PE industriais e de serviços & 1 & 1 & Não \\
\hline Experiência com PME em cargo de diretoria de uma indústria & 1 & 2 & Não \\
\hline Experiência de evento anterior com encomendas e divulgação do negócio & 1 & 1 & Não \\
\hline $\begin{array}{l}\text { Experiência desenvolvida em escritórios contábeis contribui para experiência prática de } \\
\text { tudo um pouco }\end{array}$ & 1 & 1 & Não \\
\hline Experiência em escritórios de contabilidade, escritório familiar & 1 & 1 & Não \\
\hline $\begin{array}{l}\text { Experiência empresarial com serviços e em empreendimentos de diferentes } \\
\text { maturidades }\end{array}$ & 1 & 1 & Não \\
\hline Experiência exclusiva com pequenas empresas & 1 & 2 & Não \\
\hline Explicação dos conceitos e ajuste de relatório de acordo com a vontade do cliente & 1 & 1 & Não \\
\hline Explicando a competência para aumentar sua aceitação & 1 & 1 & Não \\
\hline Explicar até que os conceitos sejam entendidos pelo cliente & 1 & 1 & Não \\
\hline Externalização da culpa: governo e concorrência & 1 & 1 & Não \\
\hline Faccamp, primeiro mestrado profissional de ADM de PME e Empreendedorismo & 1 & 1 & Não \\
\hline Faculdade não lhe deu formação para a serviço técnico: despachante & 1 & 1 & Não \\
\hline Faculdade não prepara contador com visão de LP & 1 & 1 & Não \\
\hline $\begin{array}{l}\text { Falta à classe contábil organização para lutar pode redução de obrigações acessórias } \\
\text { redundantes }\end{array}$ & 1 & 1 & Não \\
\hline Falta aos contadores visão de que se o cliente cresce, o contador também tem vantagem & 1 & 1 & Não \\
\hline
\end{tabular}




\section{Nome do nó}

Codificação Inicial

Falta condição ao empresário para melhor aproveitar da ajuda de consultores

Falta de conhecimento em gestão seria um fator de contribuição para a morte precoce da PE

Falta de dinheiro para ações de marketing: divulgação mais eficazes

Falta de domínio em contabilidade pode enviesar a visão sobre ela

Falta de Fluxo de Caixa

Falta de gestão e informação na PE

Falta de informações para passar ao consultor

Falta de maturidade empresarial compromete visão estratégica

Falta de maturidade na gestão

Falta de noção de gestão leva o empresário a se frustrar com o sonho de ter sua empresa

Falta de percepção de valor na formação do preço

Falta de planejamento e organização

Falta de preocupação com a profissionalização da gestão pode ter causa na origem e nível educacional do PAPN

Falta de preparo dos empresários

Falta de recursos financeiros e tecnológicos

Falta de recursos para treinar equipe $\mathrm{X}$ alto padrão de vida de alguns PAPNs

Falta de recursos, dinheiro e tempo, para o empresário se profissionalizar, contratar consultoria

Falta de tempo e dinheiro na PE

Falta igualdade de condições para o pequeno crescer

Falta na formação em contabilidade uma estratégia de ensino diferente, que prepare o aluno para saber demonstrar o benefício prático da contabilidade

Falta união da classe contábil para lutar por mais suporte do governo e redução de burocracia, obrigações acessórias

Faltam profissionais que além de conhecer a lei, saibam interpretá-las, indicar o caminho passo a passo

Faltou dinheiro para pagar serviço de alteração de endereço para o contador fazer

Faltou planejamento para lidar com a sazonalidade do negócio

Fase inicial da empresa o foco é como ter o melhor produto, à medida que consegue $\mathrm{e}$ cresce, o planejamento tributário passa a ser uma preocupação mais efetiva

Fases pelas quais a empresa tem que passar à luz da Teoria do ciclo de vida das organizações

Fator chave do negócio foi satisfação pessoal

Faz gestão por relatórios próprios e não pela contabilidade

Fazer a contabilidade gerencial no cliente impediria ter tantos clientes

Fazer a parte técnica na empresa grande e não participar das reuniões era uma das coisas que deixava a profissional desmotivada e sentindo-se desvalorizada

Fazer cliente engolir competência goela abaixo

FEA forma aluno para gerência, esse aluno não sabe sobre impostos

Fechou a empresa tão logo não foi mais exigida por seus contratadores

Feedbacks sobre a situação da organização da empresa

Feijoada para recém-nascido: equilíbrio da exposição a questões de controle, jurídicas e tributárias no período nascente e frágil do negócio

Fez cursos de gestão no SEBRAE

Fez plano de negócios completo a partir do segundo ano \begin{tabular}{l|r} 
Quant. & $\begin{array}{c}\text { Quant. } \\
\text { Fontes }\end{array}$ \\
Referências
\end{tabular} Nó mantido

\begin{tabular}{|l|}
1 \\
1
\end{tabular}

1

Não 


\begin{tabular}{|c|c|c|c|}
\hline \multirow[b]{2}{*}{ Nome do nó } & \multicolumn{2}{|c|}{ Codificação Inicial } & \multirow[b]{2}{*}{$\begin{array}{c}\text { Nó } \\
\text { mantido } \\
\text { na } \\
\text { Focada? }\end{array}$} \\
\hline & $\begin{array}{l}\text { Quant. } \\
\text { Fontes }\end{array}$ & $\begin{array}{c}\text { Quant. } \\
\text { Referências }\end{array}$ & \\
\hline Fica frustrada com profissionais contábeis que dificultam em vez de facilitar & 1 & 1 & "Não \\
\hline $\begin{array}{l}\text { Financiador não sugere caminhos, escolhe o melhor para investir dentre os } \\
\text { apresentados pelo PAPN }\end{array}$ & 1 & 1 & Não \\
\hline Fiscal e folha, ao contrário do contábil, é muito o software que faz & 1 & 1 & Não \\
\hline Fiscalização trabalhista & 1 & 1 & Não \\
\hline Flexibilidade da consultoria para adaptar relatórios & 1 & 1 & Não \\
\hline $\begin{array}{l}\text { Fluxo de caixa retratado na conta corrente é mais importante na análise de crédito do } \\
\text { que a contabilidade que sub-retrata a empresa }\end{array}$ & 1 & 1 & Não \\
\hline Foi difícil fazer o enquadramento no simples sozinha & 1 & 1 & Não \\
\hline Forma o preço de suas propostas de forma um pouco intuitiva & 1 & 1 & Não \\
\hline Formação de preço do serviço técnico do escritório & 1 & 1 & Não \\
\hline Formação de preço na PE-Veterinária & 1 & 1 & Não \\
\hline Formação é importante para isso? & 1 & 1 & Não \\
\hline Formação em administração ajuda o PAPN & 1 & 1 & Não \\
\hline Formação em contabilidade em Santos fraca & 1 & 1 & Não \\
\hline Formação superior incluiria preparação para consultoria & 1 & 1 & Não \\
\hline Formação técnica em contabilidade cada vez mais limitada aos serviços de despachante & 1 & 1 & Não \\
\hline Formalização como ponto crucial & 1 & 1 & Não \\
\hline Formato de cobrança da consultoria & 1 & 1 & Não \\
\hline Formato permite cuidar mais dos filhos & 1 & 1 & Não \\
\hline $\begin{array}{l}\text { Funcionária mais antiga resiste à formação superior, porém, há uma relação de } \\
\text { confiança com a Contadora, dona do escritório }\end{array}$ & 1 & 1 & Não \\
\hline $\begin{array}{l}\text { Funcionário do escritório contábil com poder de delegação e com habilidade para } \\
\text { atender o cliente }\end{array}$ & 1 & 1 & Não \\
\hline $\begin{array}{l}\text { Funcionário do escritório de contabilidade com iniciativa e disposição para buscar a } \\
\text { informação }\end{array}$ & 1 & 1 & Não \\
\hline Funcionário multitarefa no escritório contábil & 1 & 1 & Não \\
\hline Futuro da contabilidade em 20 anos está na consultoria & 1 & 1 & Não \\
\hline Geração busca acumular experiência em diversos lugares e abrir seu negócio & 1 & 1 & Não \\
\hline Geração de contadores mais velhos não vão mudar & 1 & 1 & Não \\
\hline Geração não separa vida profissional e pessoal e busca satisfação & 1 & 1 & Não \\
\hline Gestão amadora como entrave para controle gerencial & 1 & 1 & Não \\
\hline Gestão de custo fundamental para os empresários & 1 & 1 & Não \\
\hline Gestão e controle dos incubados, trabalho de BackOffice dos apoiadores da empresa & 1 & 1 & Não \\
\hline Gestão madura planeja o futuro & 1 & 1 & Não \\
\hline $\begin{array}{l}\text { Gestão não profissional e sonegação acarretam baixos níveis de qualidade do produto } \\
\text { ou serviço da MPE }\end{array}$ & 1 & 1 & Não \\
\hline $\begin{array}{l}\text { Gestão profissional igual a ter orçamento formal, planejamento de futuro, fluxo de } \\
\text { caixa e treinamento de funcionários }\end{array}$ & 1 & 1 & Não \\
\hline Gosto em saber como o crédito financeiro está auxiliando as empresas & 1 & 1 & Não \\
\hline Gosto pela área contábil & 1 & 1 & Não \\
\hline $\begin{array}{l}\text { Governo exige cumprimento de uma série de obrigações acessórias, mas não dá suporte } \\
\text { aos contadores }\end{array}$ & 1 & 1 & Não \\
\hline $\begin{array}{l}\text { Governo exige, mas não dá suporte ao contribuinte, exemplo da NFe sem que haja } \\
\text { infraestrutura de internet }\end{array}$ & 1 & 1 & Não \\
\hline Graduação ajuda, mas não prepara consultor & 1 & 1 & Não \\
\hline Graduação como possibilidade de expandir campo de atuação & 1 & 1 & Não \\
\hline
\end{tabular}




\begin{tabular}{|c|c|c|c|}
\hline \multirow[b]{2}{*}{ Nome do nó } & \multicolumn{2}{|c|}{ Codificação Inicial } & \multirow[b]{2}{*}{$\begin{array}{c}\text { Nó } \\
\text { mantido } \\
\text { na } \\
\text { Focada? }\end{array}$} \\
\hline & $\begin{array}{l}\text { Quant. } \\
\text { Fontes }\end{array}$ & $\begin{array}{c}\text { Quant. } \\
\text { Referências }\end{array}$ & \\
\hline Graduação deu dicas, sua maior preparação foi na pós-graduação & 1 & 1 & Não \\
\hline Graduação ensinou o débito e o crédito & 1 & 1 & Não \\
\hline $\begin{array}{l}\text { Graduação não preparou os contadores para a atuação com MPE em escritórios } \\
\text { contábeis }\end{array}$ & 1 & 1 & Não \\
\hline Graduação não preparou para atendimento de obrigações fiscais & 1 & 1 & Não \\
\hline Grandes escritórios de arquitetura versus pequenos & 1 & 1 & Não \\
\hline $\begin{array}{l}\text { Há clientes que não escutam a orientação: risco do estado atual e alternativa para } \\
\text { solução dada pela contadora, só mudam quando o auto de infração chega }\end{array}$ & 1 & 1 & Não \\
\hline $\begin{array}{l}\text { Há empresários mais fechados ao conhecimento de negócios, querem apenas trabalhar } \\
\text { na operação }\end{array}$ & 1 & 1 & Não \\
\hline $\begin{array}{l}\text { Há empresários que não entendem a informação gerada pela contabilidade, contadora } \\
\text { acaba 'mastigando' a informação e, assim, tomando a decisão no lugar dele }\end{array}$ & 1 & 1 & Não \\
\hline Há exceções, mas sua geração quer ter seu negócio & 1 & 1 & Não \\
\hline Há pessoas formadas em ADM que não fazem o básico & 1 & 1 & Não \\
\hline Hoje é preciso ser um profissional com discernimento crítico & 1 & 2 & Não \\
\hline $\begin{array}{l}\text { Honorário contábil baixo X atenção personalizada que o empresário de EBT incubada } \\
\text { precisa }\end{array}$ & 1 & 1 & Não \\
\hline Honorário contábil X custos do escritório dificultaria maior dedicação ao PAPN & 1 & 1 & Não \\
\hline Idade como dificultador para procurar emprego com alternativa ao empreendedorismo & 1 & 1 & Não \\
\hline $\begin{array}{l}\text { Idade como fator que influencia a flexibilidade do contador em se adaptar à realidade } \\
\text { do cliente }\end{array}$ & 1 & 1 & Não \\
\hline Ideia de parceria com empresas dos arredores & 1 & 1 & Não \\
\hline Ideias mirabolantes para reduzir impostos no ímpeto de ganhar dinheiro & 1 & 1 & Não \\
\hline Identificar o problema e propor soluções & 1 & 1 & Não \\
\hline IFRS ajudará o processo de pensamento na contabilidade brasileira & 1 & 1 & Não \\
\hline $\begin{array}{l}\text { IFRS e a separação da contabilidade fiscal aumentaram a consciência sobre se ter uma } \\
\text { informação melhor }\end{array}$ & 1 & 1 & Não \\
\hline $\begin{array}{l}\text { IFRS para PME como avanço porque permite ao contador não ser apenas um emissor } \\
\text { de guias }\end{array}$ & 1 & 1 & Não \\
\hline $\begin{array}{l}\text { IFRS vai contribuir para aumentar a importância da contabilidade, em empresas de } \\
\text { todos os portes }\end{array}$ & 1 & 1 & Não \\
\hline $\begin{array}{l}\text { Imagina que o descaso do seu contador seja por que seu negócio é muito pequeno, ou } \\
\text { ele pense que está falindo }\end{array}$ & 1 & 1 & Não \\
\hline Imediatismo faz com que PAPN não contrate consultoria preventiva & 1 & 1 & Não \\
\hline Imediatismo X Maturidade empresarial & 1 & 1 & Não \\
\hline Impacto do apoio à PE na geração de empregos & 1 & 1 & Não \\
\hline Impacto do regime tributário na formação de preço do serviço do escritório & 1 & 1 & Não \\
\hline Importância da formação para mudança da mentalidade dos novos contadores & 1 & 1 & Não \\
\hline Importância da formalização para a divulgação do negócio & 1 & 1 & Não \\
\hline $\begin{array}{l}\text { Importância da linguagem acessível a ser usada pelo Contador-Consultor ao esclarecer } \\
\text { dúvidas do cliente }\end{array}$ & 1 & 1 & Não \\
\hline $\begin{array}{l}\text { Importância da manutenção da confiança dos clientes no processo de transição na } \\
\text { aquisição de carteira de clientes no escritório contábil }\end{array}$ & 1 & 1 & Não \\
\hline Importância de começar o negócio formalmente e com contrato social bem feito & 1 & 1 & Não \\
\hline $\begin{array}{l}\text { Importância de consultoria de apoio técnico-informacional ao Contador, pois não dá } \\
\text { tempo de ler tudo o que é necessário }\end{array}$ & 1 & 1 & Não \\
\hline $\begin{array}{l}\text { Importância de manter alinhamento com Contador para não incorrer em risco sem } \\
\text { saber }\end{array}$ & 1 & 1 & Não \\
\hline Importância de mostrar ao cliente o benefício atrelado ao serviço contratado & 1 & 1 & Não \\
\hline
\end{tabular}




\begin{tabular}{|c|c|c|c|}
\hline \multirow[b]{2}{*}{ Nome do nó } & \multicolumn{2}{|c|}{ Codificação Inicial } & \multirow[b]{2}{*}{$\begin{array}{c}\text { Nó } \\
\text { mantido } \\
\text { na } \\
\text { Focada? }\end{array}$} \\
\hline & $\begin{array}{l}\text { Quant. } \\
\text { Fontes }\end{array}$ & $\begin{array}{l}\text { Quant. } \\
\text { Referências }\end{array}$ & \\
\hline Importância de renegociar as dívidas com credores & 1 & 1 & "Não \\
\hline Importância de se ter as informações para decisão em uma única folha & 1 & 1 & Não \\
\hline $\begin{array}{l}\text { Importância de se ter uma equipe qualificada para oferecer o melhor serviço ao cliente } \\
\text { do escritório contábil }\end{array}$ & 1 & 1 & Não \\
\hline $\begin{array}{l}\text { Importância de sócios estarem alinhados. Conflito de objetivos e egos consomem muita } \\
\text { energia }\end{array}$ & 1 & 1 & Não \\
\hline Importância do contador ter conhecimento, ter formação & 1 & 1 & Não \\
\hline Importância do dinheiro para o negócio funcionar & 1 & 1 & Não \\
\hline Importância do primeiro cliente, da venda piloto na empresa nascente e inovadora & 1 & 1 & Não \\
\hline Impostos desproporcionais a situação da empresa iniciante & 1 & 1 & Não \\
\hline Incentivado à Formação técnica como opção mais rápida de atuação & 1 & 1 & Não \\
\hline Incentivo para perder vergonha de fazer as perguntas tidas como óbvias & 1 & 1 & Não \\
\hline Incubada indica caminhos, mas quem decide é o empresário & 1 & 1 & Não \\
\hline Incubadora contou com parceria para oferecer aos incubados os produtos do SEBRAE & 1 & 1 & Não \\
\hline $\begin{array}{l}\text { Incubadora procura estabelecer parcerias para ampliar as possibilidades de apoio aos } \\
\text { incubados }\end{array}$ & 1 & 1 & Não \\
\hline Indicação do que esperar do contador e o que entregar a ele para que faça o trabalho & 1 & 1 & Não \\
\hline Inflexibilidade na negociação quando houve subvaloração de honorário antes & 1 & 1 & Não \\
\hline $\begin{array}{l}\text { Informação decisória para ajustar o caminho em um único lugar, de forma rápida e } \\
\text { simples }\end{array}$ & 1 & 1 & Não \\
\hline Informação sobre rentabilidade do negócio & 1 & 1 & Não \\
\hline Informações disponíveis para decisão similar ao quadro de bordo de um avião & 1 & 1 & Não \\
\hline Informações gráficas & 1 & 1 & Não \\
\hline Informalidade faz com empresário e contador não tenham o mesmo 'livro' contábil & 1 & 1 & Não \\
\hline Informatização do Governo caminha para impedir a sonegação & 1 & 1 & Não \\
\hline $\begin{array}{l}\text { Informatização do Governo como dificultador para as jogadas para enquadramento } \\
\text { fiscal indevido }\end{array}$ & 1 & 1 & Não \\
\hline Informatização do Governo como oportunidade para o mercado de consultoria & 1 & 1 & Não \\
\hline $\begin{array}{l}\text { Informatização do Governo como risco a existência do escritório para serviços de } \\
\text { despachante }\end{array}$ & 1 & 6 & Não \\
\hline $\begin{array}{l}\text { Informatização do Governo contribui para o trabalho do Contador à medida que } \\
\text { dificulta as possibilidades de sonegação }\end{array}$ & 1 & 1 & Não \\
\hline Informatização do Governo X privacidade do contribuinte & 1 & 1 & Não \\
\hline Iniciativa de planejamento tributário parte da curiosidade e cuidado do empresário & 1 & 1 & Não \\
\hline Início de escritório contábil via aquisição de carteira de clientes & 1 & 1 & Não \\
\hline Iniciou o negócio sabendo quanto deveria vender para pagar as contas & 1 & 2 & Não \\
\hline Inquietação com gastos com impostos que nunca voltam para a empresária & 1 & 1 & Não \\
\hline $\begin{array}{l}\text { Insistência do contador na explicação de melhores práticas, pois pode demorar para o } \\
\text { empresário incorporar a ideia }\end{array}$ & 1 & 1 & Não \\
\hline $\begin{array}{l}\text { Insistência em um curso voltado à grande empresa pela qualidade e gratuidade da } \\
\text { instituição }\end{array}$ & 1 & 1 & Não \\
\hline $\begin{array}{l}\text { Instâncias governamentais podiam apoiar o pequeno na sua fase nascente, facilitar } \\
\text { trâmites }\end{array}$ & 1 & 1 & Não \\
\hline Interesse pelos relatórios vai aumentando quando há referências & 1 & 1 & Não \\
\hline Já teve contador Gerencial que propunha reunião para discutir rumos do negócio & 1 & 1 & Não \\
\hline Largaram o trabalho para empreender negócio próprio & 1 & 1 & Não \\
\hline $\begin{array}{l}\text { Lei de lavagem de dinheiro pegou direto o contador, quem deve avisar o COAF de } \\
\text { qualquer suspeita de lavagem de dinheiro }\end{array}$ & 1 & 1 & Não \\
\hline
\end{tabular}




\section{Nome do nó}

Codificação Inicial

Leva o bebê à empresa por necessidade e falta de recurso

Levantamento de custo não apurado, mas acredita que será baixo

Limitações de ascensão atuando como funcionária de escritório

Limpeza da carteira de clientes: não aceitar fazer falcatruas faz com que clientes ruins deixem o escritório

Lista incompleta de despesas com o negócio

Longo período de maturação do negócio, uma particularidade da EBT Incubada

Lucro real mais trabalhoso e custoso para o contador

Má fé de contador ao saber o problema, mas não tomar atitude

Maior dedicação do Contador esbarra no baixo honorário que recebe da MPE

Maior mérito de seu contador é promover tranquilidade quanto à fiscalização

Maioria de seus grandes clientes tem formação acadêmica e maior preocupação com a administração do negócio

Maioria dos clientes do seu escritório são MPEs do simples

Maioria dos empresários da PE não aprendeu a confiar no contador

Maioria dos PAPNs não se programa, não faz planejamento

Mais declarações igual a maior possibilidade de se cobrar multa

Mal recebe assistência do contador em relação a impostos

Mandar a lei para quem tem dificuldade de compreendê-la não vai ajudar

Mantinha rotina de controles quando havia maior faturamento: movimentação

Manutenção dos serviços técnicos por ser renda constante X sazonalidade da consultoria

Marca desenvolvida e registro aguardando formação de caixa

Margem de contribuição X volume de vendas

Marido chama a atenção para a dificuldade da empresária em seguir com o programado

Material de treinamento voltado a PME mais completo

Material de treinamento voltado a PME mais mastigado

Maternidade foi crucial na decisão de empreender, queria trabalhar para sia

Maturidade do empresário e da empresa

Maturidade do empresário pela dor

Maturidade empresarial é diferente da idade

Medo do empresário de abrir informações

MEI como fator limitador para o crescimento, empresário preferi não crescer para não pagar mais imposto

MEI como fator limitador, para não aumentar imposto, empresário omite faturamento acima do teto

Menor número na contabilidade para pagar menos imposto atrapalha na análise de crédito

Mentoria de alunos, futuros empreendedores

Mercado é quem determina o preço

Mestrado pausou a consultoria

Metodologia da consultoria aprendida vendo trabalho de outros consultores

Migração para a área acadêmica

Mistura comum da PF com a PJ

Mistura da PJ com a PF

Morosidade dos serviços públicos no atendimento às empresas 'iniciar negócios irregularmente e correr risco' ou 'perder oportunidade'

\begin{tabular}{l|c} 
Quant. & $\begin{array}{c}\text { Quant. } \\
\text { Referências }\end{array}$
\end{tabular}

Nó

mantido

na

Focada?

Não

Não

Não

Não

Não

Não

Não

Não

Não

Não

Não

Não

Não

Não

Não

Não

Não

Não

Não

Não

Não

Não

Não

Não

Não

Não

Não

Não

Não

Não

Não

Não

Não

Não

Não

Não

Não

Não

Não

Não 


\begin{tabular}{|c|c|c|c|}
\hline \multirow[b]{2}{*}{ Nome do nó } & \multicolumn{2}{|c|}{ Codificação Inicial } & \multirow[b]{2}{*}{$\begin{array}{c}\text { Nó } \\
\text { mantido } \\
\text { na } \\
\text { Focada? }\end{array}$} \\
\hline & $\begin{array}{l}\text { Quant. } \\
\text { Fontes }\end{array}$ & $\begin{array}{l}\text { Quant. } \\
\text { Referências }\end{array}$ & \\
\hline $\begin{array}{l}\text { Morosidade para solucionar questões de regularização quando não há previsão legal } \\
\text { específica para o negócio }\end{array}$ & 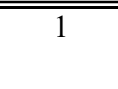 & 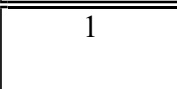 & Não \\
\hline Mortalidade de startups antes de colocarem seu produto no ar & 1 & 1 & Não \\
\hline Movimentação bancária da PE é usada para estabelecimento de limite de crédito & 1 & 1 & Não \\
\hline MPE geralmente familiar, personalizada & 1 & 1 & Não \\
\hline $\begin{array}{l}\text { MPE não poderia participar de certas licitações por causa de seu regime tributário } \\
\text { simplificado }\end{array}$ & 1 & 2 & Não \\
\hline MPE não poderia participar de certas licitações por causa tamanho do faturamento & 1 & 1 & Não \\
\hline MPE sem relatórios financeiros, gestão contábil e departamentalização & 1 & 1 & Não \\
\hline MPE tem problemas ou isso são características do seu estágio de vida? & 1 & 1 & Não \\
\hline MPEs acessam crédito BNDES de forma indireta & 1 & 1 & Não \\
\hline MPEs como geradoras de emprego & 1 & 2 & Não \\
\hline MPEs não tem informações, tem dados & 1 & 2 & Não \\
\hline Mudança de tecnologia e internacionalização impactam o negócio & 1 & 1 & Não \\
\hline Mudanças do negócio em função do mercado & 1 & 2 & Não \\
\hline $\begin{array}{l}\text { Muita exigência inicial por controle levaria o empreendedor a desistir ao a perder o } \\
\text { foco no produto }\end{array}$ & 1 & 1 & Não \\
\hline Muitas empresas não têm êxito no caminho & 1 & 1 & Não \\
\hline $\begin{array}{l}\text { Muito cliente não entende de contabilidade e tributas e acaba ficando na mão do } \\
\text { contador, por isso, a ética no trabalho é importante }\end{array}$ & 1 & 1 & Não \\
\hline Mulheres subavaliam as suas capacidades técnicas, empresárias e especialistas & 1 & 1 & Não \\
\hline $\begin{array}{l}\text { Mulheres tendem a incluir suas próprias limitações como dificuldade para empreender, } \\
\text { homens externalizam }\end{array}$ & 1 & 1 & Não \\
\hline $\begin{array}{l}\text { Na faculdade aprende-se a construir ferramentas, mas não em que elas ajudam de fato o } \\
\text { empresário }\end{array}$ & 1 & 1 & Não \\
\hline $\begin{array}{l}\text { Na grande empresa o contador foi forçado a ir além da técnica para não ser expelido do } \\
\text { mercado, na pequena isso ainda irá acontecer }\end{array}$ & 1 & 2 & Não \\
\hline $\begin{array}{l}\text { Na sucessão familiar, filho estudado tem maior predisposição à contratação de } \\
\text { consultoria preventiva que o pai }\end{array}$ & 1 & 1 & Não \\
\hline Não basta confiar nos softwares, é preciso conferir & 1 & 2 & Não \\
\hline $\begin{array}{l}\text { Não concordava com a filosofia dos escritórios para quem trabalhava, daí mais uma } \\
\text { razão para empreender }\end{array}$ & 1 & 1 & Não \\
\hline $\begin{array}{l}\text { Não conhece caso no CIETEC que a empresa faliu por problema na gestão adm- } \\
\text { financeira-contábil }\end{array}$ & 1 & 1 & Não \\
\hline $\begin{array}{l}\text { Não consegue cobrar muito e com margem de lucro baixa, não consegue pagar bem aos } \\
\text { seus colaboradores }\end{array}$ & 1 & 1 & Não \\
\hline Não consegue subir seu preço porque seus concorrentes cobram pouco & 1 & 1 & Não \\
\hline Não consegue ter lucro maior que $5 \%$ & 1 & 1 & Não \\
\hline $\begin{array}{l}\text { Não dá para fazer milagre: Relação comercial do escritório contábil com cliente que } \\
\text { paga honorário pequeno }\end{array}$ & 1 & 1 & Não \\
\hline $\begin{array}{l}\text { Não é a contabilidade complexa da grande empresa, mas uma contabilidade simples } \\
\text { que permita ao PAPN avaliar se está ganhando ou perdendo dinheiro com seu negócio }\end{array}$ & 1 & 1 & Não \\
\hline $\begin{array}{l}\text { Não é fácil ser empresário de PE, são muitas as variáveis de incertezas, mesmo que se } \\
\text { prepare }\end{array}$ & 1 & 1 & Não \\
\hline $\begin{array}{l}\text { Não é necessário ser contador para apurar a FOPAG, embora essa seja mais } \\
\text { complicada }\end{array}$ & 1 & 1 & Não \\
\hline Não é necessário ser contador para apurar os impostos e cumprir as obrigações fiscais & 1 & 1 & Não \\
\hline Não entende até onde o contador pode ajudar & 1 & 2 & Não \\
\hline
\end{tabular}




\section{Nome do nó}

Codificação Inicial

Não entendia os impostos e nem se importava em entender

Não existe consciência de que o contador é parceiro

Não gostar de resolver problemas, empreendedor frustrado

Não há interesse dos contadores em MEI

Não havia espaço-oportunidade para voltar a empreender com a dança

Não iniciou o negócio com planejamento formal, mas conhecia oportunidades e clientes potenciais

Não pretendia lançar a empresa antes do PN estar concluído, mas não podia deixar a oportunidade passar

Não quer explorar ninguém, acredita que as pessoas devem estar felizes trabalhando

Não quer pagar mal para seus funcionários

Não quer ser grande porque não quer só administrar o negócio, gosta do operacional

Não queria investir demais no começo e nem começar sem a empresa estar estruturada

Não recontrataria a contadora que tem lhe apoiado de graça porque quer um contadorparceiro no futuro

Não sabe se caberia à contabilidade ajudar a pensar o negócio do ponto de vista prospectivo

Não sabe se vai encontrar um contador parceiro ou se isso é utopia

Não sabem captar clientes, ter clientes seria uma vontade divina, um mistério

Não se pode colocar goela abaixo coisas que não servem para a empresa

Não se trata só de ganhar dinheiro, é estar fazendo o que se deseja com gente na mesma vibração

Não sentiu falta de um profissional contábil para sua empresa MEI

Não tem cabeça para pensar na gestão, precisa que lhe pegue pela mão

Não tem clareza sobre o que pode fazer sozinha e que precisa do contador

Não tem contador para o negócio que ainda está informal

Não tem previsão da rentabilidade, acredita que será alta porque seu serviço é intelectual

Não tem um planejamento formal, mas tem ideia do que quer que aconteça semanalmente em sua empresa

Não utiliza e nem entende o que recebe da contabilidade, apenas assina

Não vão entender se contadores falarem de conceitos pesados e avançados

Não vê relação custo-benefício em pagar salário mínimo ao contador apenas para emissão de guias de impostos

Necessidade de conhecer o ponto de equilíbrio

Necessidade de reforma tributária que realmente trouxesse isonomia tributária entre grandes e PE

Necessidade de se pesquisar para depois responder o cliente

Necessidade de se reinventar

Negócio começou pela rede de amizades

Negócio em espaço tipo coworking

Negócio nasceu da ideia de um pequeno bazar de natal

Negócio precisa de todas as competências, não o empreendedor

Negócio que quebrou na época da bolha da internet

Negócio quebrou antes de se tornar real, na fase especulativa

Negócios educacionais enfrentam cultura de que educação tem que ser pública e que empreendedor aí é ganancioso

Nem todo empresário está disposto a aprender o que academia oferece

Nó

mantido

na

Focada?

Fontes

Referência

\begin{tabular}{l|l}
1 & Não
\end{tabular}

\begin{tabular}{|l|l|}
\hline 1 & \\
1 & \\
1 & \\
1 &
\end{tabular}

Não

Não

Não

Não

Não

Não

Não

\begin{tabular}{|l|l|}
1 & \\
\hline 1 & 1 \\
\hline
\end{tabular}

\begin{tabular}{|l|l|}
1 & \\
1 & \\
1 & 1 \\
\hline
\end{tabular}

Não

Não

Não

Não

Não

Não

Não

Não

Não

Não

Não

Não

Não

Não

Não

Não

Não

Não

Não

Não

Não

Não

Não

Não

Não

Não

Não

Não

Não

Não 


\begin{tabular}{|c|c|c|c|}
\hline \multirow[b]{2}{*}{ Nome do nó } & \multicolumn{2}{|c|}{ Codificação Inicial } & \multirow[b]{2}{*}{$\begin{array}{c}\text { Nó } \\
\text { mantido } \\
\text { na } \\
\text { Focada? }\end{array}$} \\
\hline & $\begin{array}{l}\text { Quant. } \\
\text { Fontes }\end{array}$ & $\begin{array}{c}\text { Quant. } \\
\text { Referências }\end{array}$ & \\
\hline Nem todo PAPN tem a ambição de fazer o negócio crescer & 1 & 1 & Não \\
\hline Nem todos contadores vão querer sair da parte técnica e ir para a parte mais reflexiva & 1 & 1 & Não \\
\hline $\begin{array}{l}\text { Nível de escolaridade do país subiu, isso chega também às MPEs e deve melhorar a } \\
\text { qualidade da gestão }\end{array}$ & 1 & 1 & Não \\
\hline $\begin{array}{l}\text { No início do empreendimento, contador deve caminhar junto com empresário, dando- } \\
\text { lhe sugestões de como agir }\end{array}$ & 1 & 1 & Não \\
\hline No passado mantinha fluxo de caixa organizado e contador ajudou nisso & 1 & 1 & Não \\
\hline Nova geração de contadores já teriam uma visão diferente & 1 & 1 & Não \\
\hline Num segundo momento, abriu empresa por decisão de ser autônoma & 1 & 1 & Não \\
\hline Número de clientes como limitador para as visitas & 1 & 1 & Não \\
\hline $\begin{array}{l}\text { Nunca conversou com contadora sobre outros formatos de relatórios por } \\
\text { desconhecimento }\end{array}$ & 1 & 1 & Não \\
\hline Nunca entrou em detalhamento sobre o quotidiano do negócio com a contabilidade & 1 & 1 & Não \\
\hline $\begin{array}{l}\text { Nunca quis ter seu próprio negócio, mas sua personalidade criativa talvez tenha a } \\
\text { levado para isso }\end{array}$ & 1 & 1 & Não \\
\hline $\begin{array}{l}\text { O apoio do contador é diferente nas fases iniciais do negócio, quando a empresa ainda } \\
\text { está se inserindo no mercado }\end{array}$ & 1 & 1 & Não \\
\hline $\begin{array}{l}\text { O bom contador é aquele que consegue fazer a empresa pagar menos impostos, não } \\
\text { importa o meio }\end{array}$ & 1 & 1 & Não \\
\hline $\begin{array}{l}\text { O conhecimento das margens e rentabilidade por área como base para decisões do } \\
\text { funcionamento do negócio }\end{array}$ & 1 & 1 & Não \\
\hline O contador do escritório não priorizou ter visão de consultor & 1 & 1 & Não \\
\hline $\begin{array}{l}\text { O contador é o cara mais próximo do empresário que não tem domínio de técnicas de } \\
\text { gestão }\end{array}$ & 1 & 1 & Não \\
\hline $\begin{array}{l}\text { O contador na empresa grande acaba atuando em um pedacinho do todo, no escritório o } \\
\text { conhecimento é mais holístico }\end{array}$ & 1 & 1 & Não \\
\hline $\begin{array}{l}\text { O desejo de empreender veio com a gravidez e a vontade de ter horário de trabalho que } \\
\text { lhe permitisse ficais mais com seu bebê }\end{array}$ & 1 & 1 & Não \\
\hline O dinheiro não é agora & 1 & 1 & Não \\
\hline $\begin{array}{l}\text { O enquadramento inicial como decoração para entrar no SIMPLES foi o único } \\
\text { aconselhamento que recebeu de seu contador }\end{array}$ & 1 & 1 & Não \\
\hline O escritório especializado na EBT seria o mais indicado para ajudar essas empresas & 1 & 1 & Não \\
\hline O hobby virou trabalho, virou empreendimento & 1 & 1 & Não \\
\hline $\begin{array}{l}\text { O PAPN que não tem perfil empreendedor é, geralmente, aquele com pouca formação } \\
\text { acadêmica }\end{array}$ & 1 & 1 & Não \\
\hline O peso do honorário do contador no orçamento da sua empresa & 1 & 1 & Não \\
\hline O peso dos impostos e taxas sobre uma empresa nascente & 1 & 1 & Não \\
\hline $\begin{array}{l}\text { O pouco de melhoria de gestão que o contador levar ao empresário, que não tem, é } \\
\text { muito, faz diferença }\end{array}$ & 1 & 1 & Não \\
\hline O que foi aprendido na faculdade é pouco demandado pelos PAPNs & 1 & 1 & Não \\
\hline O serviço de contabilidade está determinado em legislação, contador segue a regra & 1 & 1 & Não \\
\hline O trabalho do contador é preparar a informação para a tomada de decisão & 1 & 1 & Não \\
\hline $\begin{array}{l}\text { O usuário da contabilidade na PE está dentro da administração, não precisa de } \\
\text { contabilidade societária, mas sim a gerencial }\end{array}$ & 1 & 1 & Não \\
\hline $\begin{array}{l}\text { Obrigações acessórias abundantes e redundantes consomem o tempo que o Contador } \\
\text { poderia usar para outros serviços ao cliente }\end{array}$ & 1 & 1 & Não \\
\hline $\begin{array}{l}\text { Oferecimento às EBTs, por parte do escritório contábil, de serviços com padrão e } \\
\text { preços razoáveis }\end{array}$ & 1 & 1 & Não \\
\hline
\end{tabular}




\begin{tabular}{|c|c|c|c|}
\hline \multirow[b]{2}{*}{ Nome do nó } & \multicolumn{2}{|c|}{ Codificação Inicial } & \multirow[b]{2}{*}{$\begin{array}{l}\text { Nó } \\
\text { mantido } \\
\text { na } \\
\text { Focada? }\end{array}$} \\
\hline & $\begin{array}{l}\text { Quant. } \\
\text { Fontes }\end{array}$ & $\begin{array}{l}\text { Quant. } \\
\text { Referências }\end{array}$ & \\
\hline $\begin{array}{l}\text { Oferecimento de orientação da contadora para questões de contratação e folha de } \\
\text { pagamento }\end{array}$ & 1 & 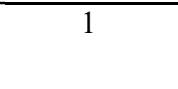 & Não \\
\hline $\begin{array}{l}\text { Oferecimento de orientação da contadora sobre impostos, sindicatos, enquadramento } \\
\text { fiscal inicial }\end{array}$ & 1 & 1 & Não \\
\hline Opção de segmentação para MPE do Simples & 1 & 1 & Não \\
\hline Opção para baratear distribuição de materiais: virtualização & 1 & 1 & Não \\
\hline Operacional da contabilidade: impostos como o começar de baixo & 1 & 1 & Não \\
\hline $\begin{array}{l}\text { Optou por voltar a trabalhar para os outros para poder ter dinheiro certo e tempo para } \\
\text { se reestruturar }\end{array}$ & 1 & 1 & Não \\
\hline Oralidade e empatia na comunicação com os empresários & 1 & 1 & Não \\
\hline $\begin{array}{l}\text { Orientação ao cliente demanda muito conhecimento técnico, fiscal-tributário e de } \\
\text { funcionamento do mercado. Contador deve estar preparado para correr atrás da } \\
\text { informação }\end{array}$ & 1 & 1 & Não \\
\hline Orientação constante e direto até o empresário captar mensagem, orientação & 1 & 1 & Não \\
\hline $\begin{array}{l}\text { Orientação para começar com controles mínimos, operações rastreáveis e transparência } \\
\text { com sócios }\end{array}$ & 1 & 1 & Não \\
\hline $\begin{array}{l}\text { Orientação para considerar custos reais, exemplo: aluguel subsidiado hoje, usar preço } \\
\text { real }\end{array}$ & 1 & 1 & Não \\
\hline Orientação sobre o mercado respeitando a experiência do PAPN & 1 & 1 & Não \\
\hline $\begin{array}{l}\text { Orientadores de carreira, como universidades, tem o papel de despertar a pessoa para o } \\
\text { empreendedorismo }\end{array}$ & 1 & 1 & Não \\
\hline Orientar só, às vezes, não basta. É preciso pegar na mão & 1 & 1 & Não \\
\hline Os alunos de hoje estudam uma nova contabilidade & 1 & 1 & Não \\
\hline $\begin{array}{l}\text { Os controles próprios dos PAPNs sã informais, em caderninhos, que fazem sentido } \\
\text { para eles }\end{array}$ & 1 & 1 & Não \\
\hline $\begin{array}{l}\text { Os encargos são pesados, mas empresária reconhece seus limitados conhecimentos de } \\
\text { gestão }\end{array}$ & 1 & 1 & Não \\
\hline $\begin{array}{l}\text { Os grandes negócios nasceram pequenos e tiveram que mudar no processo de } \\
\text { crescimento }\end{array}$ & 1 & 1 & Não \\
\hline Os problemas enfrentados pelas PMEs são os mesmos de 30 anos atrás & 1 & 1 & Não \\
\hline $\begin{array}{l}\text { Outras razões para omissão de informações ao Contador são pontuais, por sonegação é } \\
\text { a mais comum }\end{array}$ & 1 & 1 & Não \\
\hline Outros profissionais são mais competentes para ajudar com a motivação e liderança & 1 & 2 & Não \\
\hline Pagamento de muitos impostos como motivo de descontentamento com o contador & 1 & 1 & Não \\
\hline $\begin{array}{l}\text { Pagar mais para os funcionários do escritório representaria risco do funcionário querer } \\
\text { atuar sozinho }\end{array}$ & 1 & 1 & Não \\
\hline Papel consultivo do contador no ambiente complexo de negócios em que estão as PE & 1 & 1 & Não \\
\hline $\begin{array}{l}\text { Papel do contador é tentar explicar conceitos, esclarecer dúvidas e dar orientações de } \\
\text { negócios }\end{array}$ & 1 & 1 & Não \\
\hline PAPN acaba fazendo de tudo na PE, sua rotina não é fácil & 1 & 1 & Não \\
\hline $\begin{array}{l}\text { PAPN está mais preocupado com lucratividade, vê a consultoria como um custo e não } \\
\text { como investimento }\end{array}$ & 1 & 1 & Não \\
\hline PAPN mais velho, que deu certo sem apoio, dificilmente verá valor na consultoria & 1 & 1 & Não \\
\hline $\begin{array}{l}\text { PAPN muito envolvido a questões do dia a dia, da sobrevivência do negócio, ao curto } \\
\text { prazo }\end{array}$ & 1 & 1 & Não \\
\hline PAPN não empreendedor contenta-se com estabilidade que lhe garanta o sustento & 1 & 1 & Não \\
\hline $\begin{array}{l}\text { PAPN não investe em consultoria jurídica preventiva e acaba gastando muito quando } \\
\text { tem um problema }\end{array}$ & 1 & 1 & Não \\
\hline PAPN não tem tempo para planejamento e visão de longo prazo & 1 & 1 & Não \\
\hline
\end{tabular}




\begin{tabular}{|c|c|c|c|}
\hline \multirow[b]{2}{*}{ Nome do nó } & \multicolumn{2}{|c|}{ Codificação Inicial } & \multirow[b]{2}{*}{$\begin{array}{c}\text { Nó } \\
\text { mantido } \\
\text { na } \\
\text { Focada? }\end{array}$} \\
\hline & $\begin{array}{l}\text { Quant. } \\
\text { Fontes }\end{array}$ & $\begin{array}{l}\text { Quant. } \\
\text { Referências }\end{array}$ & \\
\hline $\begin{array}{l}\text { PAPN não teria interesse em contabilidade societária de qualidade, já que toma } \\
\text { decisões baseadas em relatórios gerenciais }\end{array}$ & 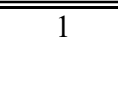 & 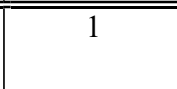 & Não \\
\hline PAPN não vê valor na contabilidade, não conta com ela na gestão & 1 & 1 & Não \\
\hline PAPN procura o contador principalmente para atender a finalidade fiscal & 1 & 1 & Não \\
\hline $\begin{array}{l}\text { PAPN que abre o negócio sem conhecimento de mercado e planejamento. Contadora } \\
\text { tenta auxílio sem cobrança adicional por isso. }\end{array}$ & 1 & 1 & Não \\
\hline PAPN que abre várias empresas para segregar faturamento e continuar no simples & 1 & 1 & Não \\
\hline $\begin{array}{l}\text { PAPN que não consegue desenvolver seu lado empreendedor, tem dificuldade de } \\
\text { prosperar, de ter negócio de impacto }\end{array}$ & 1 & 1 & Não \\
\hline PAPN que não sabe mexer em computador & 1 & 1 & Não \\
\hline PAPN reclamam da carga tributária e a associam ao governo atual & 1 & 1 & Não \\
\hline $\begin{array}{l}\text { PAPN tem } 2 \text { grandes dificuldades: Gestão Financeira, e aqui pode ser ajudado, e Perfil } \\
\text { Empreendedor, aqui precisa autodesenvolver-se }\end{array}$ & 1 & 1 & Não \\
\hline $\begin{array}{l}\text { PAPN tem seus próprios mecanismos de controle, às vezes, intuitivos. Não usa a } \\
\text { contabilidade para isso. }\end{array}$ & 1 & 1 & Não \\
\hline $\begin{array}{l}\text { PAPN tem técnicas internas para adquirir informações e tomar decisão, igualmente } \\
\text { válidas }\end{array}$ & 1 & 1 & Não \\
\hline PAPN toca empresa com heroísmo, mas sem profissionalizar gestão & 1 & 1 & Não \\
\hline $\begin{array}{l}\text { PAPN usaria a contabilidade se fosse feita com um Plano de Contas direcionado à } \\
\text { gestão, adaptado às necessidades decisórias do gestor }\end{array}$ & 1 & 1 & Não \\
\hline PAPNs com instrução maior tende a ser mais sensível a planejamento de longo prazo & 1 & 1 & Não \\
\hline $\begin{array}{l}\text { PAPNs muito envolvidos com o dia a dia operacional e dedicam pouco tempo para a } \\
\text { gestão e o planejamento }\end{array}$ & 1 & 1 & Não \\
\hline $\begin{array}{l}\text { PAPNs prepara-se no operacional do negócio, mas não está habituado a controles } \\
\text { financeiros, administração }\end{array}$ & 1 & 1 & Não \\
\hline PAPNs sem preocupação com orçamento ou planejamento: problema ou característica & 1 & 1 & Não \\
\hline $\begin{array}{l}\text { PAPNs tem administração amadora, ao contrário das empresas com maior faturamento } \\
\text { e regime tributário diferenciado }\end{array}$ & 1 & 1 & Não \\
\hline PAPNs têm preocupações mais imediatistas, não olham para longo prazo & 1 & 1 & Não \\
\hline Para ajudar, contador precisa conhecer de gestão & 1 & 1 & Não \\
\hline $\begin{array}{l}\text { Para garantir conhecimento e firmeza em seus funcionários-familiares, contadora os } \\
\text { incentivou a fazerem faculdade }\end{array}$ & 1 & 1 & Não \\
\hline Para MEI, você faz tudo pela internet e sozinha & 1 & 1 & Não \\
\hline $\begin{array}{l}\text { Para oferecer consultoria, o Contador precisa entender em detalhes o produto e a } \\
\text { operação da empresa }\end{array}$ & 1 & 1 & Não \\
\hline $\begin{array}{l}\text { Para se reestruturar, quer fazer plano de negócios, buscar o SEBRAE e consultoria } \\
\text { especializada }\end{array}$ & 1 & 1 & Não \\
\hline Parar com a contabilidade técnica em buscas de desafios mais atrativos & 1 & 1 & Não \\
\hline Parcas noções de administração que aprendeu na marra & 1 & 1 & Não \\
\hline Parceria assessor e empresário & 1 & 1 & Não \\
\hline $\begin{array}{l}\text { Participação em grupo de empreendedores universitários fazia com que visse o } \\
\text { contador como alguém incompetente para saber do negócio }\end{array}$ & 1 & 1 & Não \\
\hline PE anã, com deformidades e que nunca irá crescer & 1 & 1 & Não \\
\hline PE com administração profissional, empresário com formação em ADM & 1 & 1 & Não \\
\hline PE familiar com gestão profissional planejamento e controle & 1 & 1 & Não \\
\hline $\begin{array}{l}\text { PE familiar desestruturada, sem saber executar projetos e com receio de acessar crédito } \\
\text { bancário }\end{array}$ & 1 & 1 & Não \\
\hline
\end{tabular}




\section{Nome do nó}

Codificação Inicial

PE não precisa de um sistema de informações gerenciais complexo, mas um controle ajustado a sua realidade e porte

PE pode ser ajudada com serviço de forma fácil que se encaixe no orçamento

PE sem dinheiro para pagar bom profissional ou consultoria

Pensar no longo prazo e assessoria

Pequena empresa só contrata escritório porque não pode manter departamento próprio

Percepção subjetiva para avaliar carga tributária

Perfil do empresário e fatores externos: governo, tributos e concorrência: definem a

relação do empresário com a gestão do negócio

Perfil empreendedor: busca informação, conhecimento e tem iniciativa

Perfis diferentes na sociedade pode ser produtivo, mas tem que tomar cuidado

Personalidade tem impacto em conhecimentos e habilidades que serão apreendidas pelo empresário

Pesquisas acadêmicas sobre mortalidade das MPEs a partir de dados do SEBRAE

Pesquisou sozinha na internet sobre trâmites de abertura MEI e como emitiria suas NFs

Pessoa que procurou Contador antes de abrir um negócio, ao conhecer os trâmites,

desistiu do projeto

Planejamento com todas as despesas do negócio

Planejamento conjunto para lidar com sazonalidades

Planejamento incluir formalização como MEI

Plano de negócios na cabeça, não está escrito

Ponderação custo $\mathrm{X}$ benefício de se detalhar a informação

Por ser uma relação de confiança, o escritório conseguia clientes por indicações

Postura consultiva igual orientação para estruturar uma contabilidade mais confiável

Potencial de contribuição da contabilidade gerencial, custos ABC, mg de contribuição

Pouca exigência inicial por controle levaria o empreendedor não se preocupar com isso

e ter problemas no momento de buscar investidores

Pouco apoio no fornecimento de planilhas, recebeu uma de gastos pessoais

Pouco recurso para assessoria

Poucos contadores teriam visão estratégica de seus escritórios

Poucos PAPNs têm o objetivo de se profissionalizar como administrador

Práticas básicas de gestão são o mínimo necessário para a sobrevivência

Precificação planejada com base na expectativa de tempo que irá se dedicar ao cliente

Precisa sacudir para não ficar no ostracismo

Precisa-se de informação para planejar o futuro

Preço do serviço do escritório calculado errado e tendo de ser revisto

Preço para cobrir custos tributários e ser rentável

Preocupação com honorário pelo cliente como fato desmotivador do profissional de contabilidade

Preocupação do empresário em pagar menos impostos

Preparar-se para as diligências contábeis do investidor

Pressão sobre a Contadora para equilibrar a equação entre perder clientes e pagar as contas do escritório

Prevê crescimento de número de clientes e contratação de funcionário

Prevê despesas fixas: impostos e taxa bancária, sem internet e telefone, que serão usadas da sua casa

Primeiro empreendimento com plano de negócios construído como projeto de pósgraduação

\begin{tabular}{|c|c|c|}
\hline \multicolumn{2}{|c|}{ Codificação Inicial } & \multirow[b]{2}{*}{$\begin{array}{c}\text { Nó } \\
\text { mantido } \\
\text { na } \\
\text { Focada? }\end{array}$} \\
\hline $\begin{array}{l}\text { Quant. } \\
\text { Fontes }\end{array}$ & $\begin{array}{c}\text { Quant. } \\
\text { Referências }\end{array}$ & \\
\hline 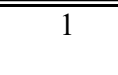 & 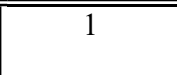 & Não \\
\hline 1 & 1 & Não \\
\hline 1 & 1 & Não \\
\hline 1 & 1 & Não \\
\hline 1 & 1 & Não \\
\hline 1 & 1 & Não \\
\hline 1 & 1 & Não \\
\hline 1 & 1 & Não \\
\hline 1 & 1 & Não \\
\hline 1 & 1 & Não \\
\hline 1 & 1 & Não \\
\hline 1 & 1 & Não \\
\hline 1 & 1 & Não \\
\hline 1 & 1 & Não \\
\hline 1 & 1 & Não \\
\hline 1 & 1 & Não \\
\hline 1 & 1 & Não \\
\hline 1 & 1 & Não \\
\hline 1 & 1 & Não \\
\hline 1 & 1 & Não \\
\hline 1 & 1 & Não \\
\hline 1 & 1 & Não \\
\hline 1 & 1 & Não \\
\hline 1 & 1 & Não \\
\hline 1 & 1 & Não \\
\hline 1 & 1 & Não \\
\hline 1 & 1 & Não \\
\hline 1 & 1 & Não \\
\hline 1 & 1 & Não \\
\hline 1 & 1 & Não \\
\hline 1 & 1 & Não \\
\hline 1 & 2 & Não \\
\hline 1 & 1 & Não \\
\hline 1 & 1 & Não \\
\hline 1 & 1 & Não \\
\hline 1 & 1 & Não \\
\hline 1 & 1 & Não \\
\hline 1 & 1 & Não \\
\hline 1 & 1 & Não \\
\hline
\end{tabular}




\begin{tabular}{|c|c|c|c|}
\hline \multirow[b]{2}{*}{ Nome do nó } & \multicolumn{2}{|c|}{ Codificação Inicial } & \multirow[b]{2}{*}{$\begin{array}{c}\text { Nó } \\
\text { mantido } \\
\text { na } \\
\text { Focada? }\end{array}$} \\
\hline & $\begin{array}{l}\text { Quant. } \\
\text { Fontes }\end{array}$ & $\begin{array}{l}\text { Quant. } \\
\text { Referências }\end{array}$ & \\
\hline Primeiro o contador tem que ver o custo de sua disponibilidade ao PAPN & 1 & 1 & "Não \\
\hline Primeiros passos da empresa foram no sentido de ser conhecida & 1 & 1 & Não \\
\hline Primordial entender do que a empresa precisa & 1 & 1 & Não \\
\hline Proatividade para buscar credores e renegociar dívidas & 1 & 1 & Não \\
\hline Problema detectado em homologação & 1 & 1 & Não \\
\hline $\begin{array}{l}\text { Problemas com relação entre sócios do escritório: passivos trabalhistas X sociedade } \\
\text { familiar }\end{array}$ & 1 & 1 & Não \\
\hline $\begin{array}{l}\text { Processos de acompanhamento da empresa com diagnósticos de diversas áreas } \\
\end{array}$ & 1 & 1 & Não \\
\hline $\begin{array}{l}\text { Professora acredita que seus colegas professores não estimulam os alunos a } \\
\text { preocuparem-se com a realidade da PE }\end{array}$ & 1 & 1 & Não \\
\hline $\begin{array}{l}\text { Professora estimula seus alunos a consultarem as necessidades de seus clientes da PE e } \\
\text { a ouvi-los }\end{array}$ & 1 & 1 & Não \\
\hline $\begin{array}{l}\text { Professora orienta para os problemas da PE e para o oferecimento de serviços } \\
\text { específicos }\end{array}$ & 1 & 1 & Não \\
\hline Profissionalização das pessoas como maior dificuldade das PEs & 1 & 1 & Não \\
\hline Propor soluções compatíveis às necessidades e realidades da PE & 1 & 1 & Não \\
\hline $\begin{array}{l}\text { Quando há plano de negócios inicial, concentram-se nas partes tecnológica e } \\
\text { comercial, deixam a administração de lado }\end{array}$ & 1 & 1 & Não \\
\hline Quando o empresário confia, abre informações, desde que as tenha, ao consultor & 1 & 1 & Não \\
\hline $\begin{array}{l}\text { Quando o empresário não consegue expor seu problema ao contador, o consultor acaba } \\
\text { captando. Teria um papel de tradutor }\end{array}$ & 1 & 1 & Não \\
\hline Quando parou o plano de marketing, conseguiu captar contrato importante de clientes & 1 & 1 & Não \\
\hline Quando planejou empreender, contava com o apoio financeiro do marido & 1 & 1 & Não \\
\hline $\begin{array}{l}\text { Quando precisou prestar contas, teve dificuldades de entender os relatórios: as } \\
\text { planilhas que possuía }\end{array}$ & 1 & 1 & Não \\
\hline Quanto maior o domínio da gestão, maior o interesse pela contabilidade & 1 & 1 & Não \\
\hline Quem atende a PE precisa saber lidar com situações complicadas & 1 & 1 & Não \\
\hline Questiona se as dificuldades existem por sua falta de planejamento & 1 & 1 & Não \\
\hline Questionamento sobre diferenças regionais no perfil dos PAPNs & 1 & 1 & Não \\
\hline Questionamentos feitos pelos empresários como porta de entrada para a consultoria & 1 & 1 & Não \\
\hline Questões éticas e conflitivas entre contadores na passagem de clientes & 1 & 1 & Não \\
\hline Questões éticas na prestação de serviços contábeis técnicos & 1 & 1 & Não \\
\hline $\begin{array}{l}\text { Razões culturais, religiosas e nível de instrução contribuem para formação de } \\
\text { empresário não empreendedor }\end{array}$ & 1 & 1 & Não \\
\hline Razões e frequência das visitas & 1 & 1 & Não \\
\hline Realidade de 20 anos atrás: PAPN não se preocupava em profissionalizar a gestão & 1 & 1 & Não \\
\hline Recebe relatórios com frequência, senão, cobra o contador & 1 & 1 & Não \\
\hline Recebimento apenas dos livros contábeis obrigatórios & 1 & 1 & Não \\
\hline Receio de compartilhar informação por parte do contador & 1 & 1 & Não \\
\hline Receio de contratar gente antes de ter trabalho e depois não ter como bancar equipe & 1 & 1 & Não \\
\hline Reconhecendo as limitações dos funcionários do escritório & 1 & 1 & Não \\
\hline $\begin{array}{l}\text { Reconhecimento de que os MPE de alimentação não têm administradores como } \\
\text { oportunidade de negócio }\end{array}$ & 1 & 1 & Não \\
\hline $\begin{array}{l}\text { Recursos escassos demandam gratuidade ou redução dos custos com materiais } \\
\text { disponibilizados }\end{array}$ & 1 & 1 & Não \\
\hline Rede de relacionamento entre contadores para debater assuntos técnicos & 1 & 1 & Não \\
\hline Redundância de declarações e obrigações acessórias como uma máquina de multas & 1 & 1 & Não \\
\hline Redundância de declarações, obrigações acessórias tomam o tempo do contador & 1 & 1 & Não \\
\hline
\end{tabular}




\section{Nome do nó}

Codificação Inicial

Reforma do espaço da empresa e início da produção antes da formalização

Regime de transição em que se fatura mais, paga mais, se, menos, paga menos. Há quem fature mais e está no simples, enquanto quem fatura menos, mas tem atividade impeditiva, está pagando mais

Regime de tributação gradativo que desse as mesmas chances de crescimento à PE

Regime tributário não é critério de definição do porte para o escritório contábil

Regime tributário único gradativo conforme crescimento do faturamento, sem distinções de ramo

Regularidade fiscal como um diferencial de sua empresa de engenharia

Relação com a contabilidade depende da visão que o empresário tem do negócio

Relação com sócios como causa para fim de empreendimento

Relação contador-empresário impediria o primeiro de dar respostas mais flexível ou até mesmo um 'não sei', consultor poderia

Relação do escritório com seus funcionários

Relação empresária-contadora é boa, mas resume-se à intermediação da relação empresa-governo

Relação mais flexível consultor-empresário deixa a comunicação mais fácil

Relacionamento com banco contribuiu para crescimento de empresa que tomou financiamento

Relacionamento com o banco para concessão de crédito acaba contribuindo para melhoria na gestão, contabilidade, controles internos etc.

Relatórios adaptados ao cliente

Remodelada do espaço após entrada de novas sócias

Remuneração do trabalho contábil

Reposicionando-se estrategicamente

Resistência do PAPN ao planejamento, entende ser adivinhação. É preciso mostrar o como fazer

Responsabilidade do contador sobre sua equipe e relação de confiança

Responsabilidades pelos erros fiscais, ora do empresário, ora do escritório

Risco alto ao fazer apenas escrita fiscal e FOPAG, escrita contábil terá sobrevida

Risco de erro do contador, custos para o escritório

Risco de inadimplência do serviço de consultoria prestado

Risco de multas e juros por não atendimento de obrigações acessórias

Risco de perder clientes da carteira adquirida do escritório contábil anterior

Risco do negócio contábil associado as questões fiscais do cliente

Riscos trabalhistas para escritórios com matriz e filial e diferenças salarias entre eles

Rotina da contabilidade técnica como desmotivador

Rotina de certidões como diferencial do escritório

Rotina de controle de atendimento e controle financeiro: caixa diário e mensal

Rotina de relatórios aumentaria custo, consequentemente, preço dos honorários

Rotina de relatórios mais explicações aumentaria a percepção de valor do cliente, quem poderia topar pagar mais por isso

Rotinas orgânica

Sabe onde buscar apoio, inclusive gratuito, mas não o faz por falta de tempo, e quando tem tempo se sente paralisado de medo

Saber demonstrar quanto o serviço contábil é importante, além do cumprimento de obrigações é importante

\begin{tabular}{c|c} 
Quant. & $\begin{array}{c}\text { Quant. } \\
\text { Fonterências }\end{array}$
\end{tabular}

Nó

mantido

na

Focada?

\begin{tabular}{|c|c|c|}
\hline 1 & 1 & Não \\
\hline 1 & 1 & \\
\hline & & Não \\
\hline
\end{tabular}

\begin{tabular}{|c|c|}
\hline 1 & 1 \\
\hline 1 & 1 \\
\hline 1 & 1 \\
\hline
\end{tabular}

Não

Não

Não

Não

Não

Não

Não

Não

Não

Não

Não

Não

Não

Não

Não

Não

Não

Não

Não

Não

Não

Não

Não

Não

Não

Não

Não

Não

Não

Não

Não

Não

Não

Não

Não 


\begin{tabular}{|c|c|c|c|}
\hline \multirow[b]{2}{*}{ Nome do nó } & \multicolumn{2}{|c|}{ Codificação Inicial } & \multirow[b]{2}{*}{$\begin{array}{c}\text { Nó } \\
\text { mantido } \\
\text { na } \\
\text { Focada? }\end{array}$} \\
\hline & $\begin{array}{l}\text { Quant. } \\
\text { Fontes }\end{array}$ & $\begin{array}{l}\text { Quant. } \\
\text { Referências }\end{array}$ & \\
\hline $\begin{array}{l}\text { Saia justa de entregar nota de decoração, quando o serviço foi de projeto de arquitetura } \\
\text { por razões tributárias. Pior quando é PJ o cliente }\end{array}$ & 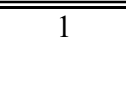 & 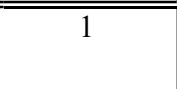 & Não \\
\hline $\begin{array}{l}\text { São poucas as pessoas de sua geração que desejam fazer carreira em uma única } \\
\text { empresa }\end{array}$ & 1 & 1 & Não \\
\hline Sazonalidade do negócio & 1 & 1 & Não \\
\hline $\begin{array}{l}\text { Se governo diminuísse número de obrigações acessórias, contador teria mais tempo } \\
\text { para assessorar seus clientes }\end{array}$ & 1 & 1 & Não \\
\hline $\begin{array}{l}\text { Se há pretensão de apoiar a aplicação das IFRS-PME, deve haver foco educacional } \\
\text { onde há maior escassez de recurso }\end{array}$ & 1 & 1 & Não \\
\hline Se não fosse obrigatória, PAPN faria contabilidade? & 1 & 1 & Não \\
\hline Se sair do simples, a sobrevivência do negócio fica comprometida & 1 & 1 & Não \\
\hline Se tivesse planejado antes, não teria aberto um negócio & 1 & 1 & Não \\
\hline Seleção natural do mercado, algumas empresas vão morrer & 1 & 1 & Não \\
\hline Sem dinheiro de investidor, fundos de fomento pode ser alternativa de financiamento & 1 & 1 & Não \\
\hline Sem endereço atualizado, as correspondências da empresa não chegam & 1 & 1 & Não \\
\hline Sem escrita contábil conseguiria reduzir pela metade honorário do escritório & 1 & 1 & Não \\
\hline Sem formação em administração, os controles financeiros foram aprendidos na prática & 1 & 1 & Não \\
\hline Sem trabalho, fica paralisada, só pensa em captar trabalho, não consegue se organizar & 1 & 1 & Não \\
\hline $\begin{array}{l}\text { Sem visão estratégica, empresa pode concentrar suas operações em um cliente e, se ele } \\
\text { afundar, ir junto }\end{array}$ & 1 & 1 & Não \\
\hline Sempre objetivou ter o próprio escritório contábil & 1 & 1 & Não \\
\hline Sendo uma empresa de arquitetura, poderia ampliar o escopo de atuação: clientes & 1 & 1 & Não \\
\hline $\begin{array}{l}\text { Sensibilidade para perceber o momento apropriado de entrar nas especificidades } \\
\text { tributárias pouco impactantes na fase nascente do negócio }\end{array}$ & 1 & 1 & Não \\
\hline Sente falta de um sócio para compartilhar os bons e maus momentos do negócio & 1 & 1 & Não \\
\hline Sente-se sozinha. Não teve retorno do contador aos seus contatos & 1 & 1 & Não \\
\hline $\begin{array}{l}\text { Sentimento de medo de que dê errado, ao mesmo tempo que sente que não pode jogar } \\
\text { tudo fora }\end{array}$ & 1 & 1 & Não \\
\hline Sentiria falta de um contador se fosse abrir outro formato de empresa que não MEI & 1 & 1 & Não \\
\hline $\begin{array}{l}\text { Sentiu-se valorizada em escritório onde tinha cargo de supervisão, bom salário, } \\
\text { subsídio para pós e reconhecimento pessoal. }\end{array}$ & 1 & 1 & Não \\
\hline Ser boa ouvinte em contexto de diferenças de personalidades & 1 & 1 & Não \\
\hline Ser empresária é trabalhar 3x mais que quando funcionária. & 1 & 1 & Não \\
\hline $\begin{array}{l}\text { Seria soberba desconsiderar a bagagem e o conhecimento que o PAPN tem de seu } \\
\text { negócio e seu jeito de gerir }\end{array}$ & 1 & 1 & Não \\
\hline $\begin{array}{l}\text { Serviço contábil é um serviço intelectual oferecido ao cliente. Qualidade deve ser } \\
\text { perseguida pelo contador }\end{array}$ & 1 & 1 & Não \\
\hline Serviço contábil fica muito limitado ao cumprimento de exigências legais & 1 & 1 & Não \\
\hline Serviço de escritório contábil como assessoria & 1 & 1 & Não \\
\hline Serviços com maior complexidade têm maior margem de lucro & 1 & 1 & Não \\
\hline Serviços contábeis oferecidos em módulos pelo escritório & 1 & 1 & Não \\
\hline Serviços contábeis se resumem a folha de pagamento e impostos & 1 & 2 & Não \\
\hline Serviços oferecidos pelo escritório: escrita fiscal, contábil, folha e paralegal & 1 & 1 & Não \\
\hline $\begin{array}{l}\text { Seus colegas na faculdade queriam trabalhar em banco, em auditoria, ela sempre quis } \\
\text { ter o próprio escritório }\end{array}$ & 1 & 1 & Não \\
\hline $\begin{array}{l}\text { Seus concorrentes pagam mal a seus colaboradores, por isso, conseguem pegar muitos } \\
\text { trabalhos. }\end{array}$ & 1 & 1 & Não \\
\hline
\end{tabular}




\begin{tabular}{|c|c|c|c|}
\hline \multirow[b]{2}{*}{ Nome do nó } & \multicolumn{2}{|c|}{ Codificação Inicial } & \multirow[b]{2}{*}{$\begin{array}{c}\text { Nó } \\
\text { mantido } \\
\text { na } \\
\text { Focada? }\end{array}$} \\
\hline & $\begin{array}{l}\text { Quant. } \\
\text { Fontes }\end{array}$ & $\begin{array}{c}\text { Quant. } \\
\text { Referências }\end{array}$ & \\
\hline Similaridades na gestão das empresas que visitou no processo de concessão de crédito & 1 & 1 & Não \\
\hline Simples como mais fácil de tocar pelo escritório contábil comparado ao presumido & 1 & 1 & Não \\
\hline Simples como uma possibilidade de cobrança de honorários menores & 1 & 1 & Não \\
\hline $\begin{array}{l}\text { Simples como uma possibilidade de cobrança de honorários menores, especialmente } \\
\text { para escritórios maiores (Nós) }\end{array}$ & 1 & 1 & Não \\
\hline Simples Nacional contribui para um honorário contábil menor & 1 & 1 & Não \\
\hline $\begin{array}{l}\text { Simples Nacional também pode ser um fator limitador do crescimento quando o } \\
\text { empresário decide crescer só até o teto do regime }\end{array}$ & 1 & 1 & Não \\
\hline $\begin{array}{l}\text { Simplificação das obrigações acessórias permitiriam ao contador ter mais tempo para } \\
\text { oferecer melhores serviços }\end{array}$ & 1 & 1 & Não \\
\hline Simulação de cenários: pagar todos os impostos e efeito no resultado & 1 & 1 & Não \\
\hline $\begin{array}{l}\text { Simulação para enquadramento pós universalização simples feitos com dados } \\
\text { retroativos e não prospectivos }\end{array}$ & 1 & 1 & Não \\
\hline Sindical patronal opcional como um dos benefícios do simples & 1 & 1 & Não \\
\hline $\begin{array}{l}\text { Sistemas de custos, empresário acham que não precisam, que é muito complexo, } \\
\text { quando na verdade precisam }\end{array}$ & 1 & 1 & Não \\
\hline Só a prática traz as respostas aos empresários & 1 & 1 & Não \\
\hline Só recebe de seu contador guia de impostos e informe de rendimento & 1 & 1 & Não \\
\hline Só vai deixar seu emprego quando a empresa lhe propiciar caixa para investimento & 1 & 1 & Não \\
\hline Sobreposição fisco-contabilidade pelo Contador & 1 & 1 & Não \\
\hline Sócia estremeceu e procurou um bico em época de pouca entrada & 1 & 1 & Não \\
\hline $\begin{array}{l}\text { Sócia que saiu e percebeu que fora do negócio também não está fácil e voltou para } \\
\text { fazer o que gosta }\end{array}$ & 1 & 1 & Não \\
\hline Sócias com alguma experiência e preparo em gestão & 1 & 1 & Não \\
\hline Sócias com objetivos comuns e em mesma época para empreender & 1 & 1 & Não \\
\hline Sócias com perfis pessoais bem diferentes & 1 & 2 & Não \\
\hline Societária igual a contrato social & 1 & 1 & Não \\
\hline Sócios também cobram & 1 & 1 & Não \\
\hline Sonegação como empecilho para assessoria & 1 & 1 & Não \\
\hline Sonegação compromete a existência da empresa no médio prazo & 1 & 1 & Não \\
\hline Sonegação do cliente como risco para o contador & 1 & 1 & Não \\
\hline $\begin{array}{l}\text { Sonegação e trabalhadores irregulares podem ser fatores impeditivos para o } \\
\text { crescimento }\end{array}$ & 1 & 1 & Não \\
\hline Sonegação fiscal como fonte do medo para abrir informações & 1 & 2 & Não \\
\hline Sonegação fiscal como impeditivo para a contabilidade refletir a realidade da empresa & 1 & 1 & Não \\
\hline Sonegadores criticam corrupção, mas não veem o problema em suas sonegações & 1 & 1 & Não \\
\hline SPED Social eliminará uma série de tarefas de folha feitas pelo contador hoje & 1 & 1 & Não \\
\hline Sua experiência com o contador é de Ausência & 1 & 1 & Não \\
\hline $\begin{array}{l}\text { Sua formação em universidade federal não lhe ensinou a lidar com o mercado, ganhar } \\
\text { dinheiro era até mal visto }\end{array}$ & 1 & 1 & Não \\
\hline Super burocracia, por exemplo, para alterar o endereço da empresa & 1 & 1 & Não \\
\hline Supervisora no escritório como barreira para aprendizado, por medo de perder cargo & 1 & 1 & Não \\
\hline Surpresa da empresária ao saber que a contabilidade podia mais & 1 & 1 & Não \\
\hline $\begin{array}{l}\text { Tem amigos competentes, conhece arquitetos famosos, que não têm dinheiro e não } \\
\text { conseguem fazer seus negócios virarem }\end{array}$ & 1 & 1 & Não \\
\hline Tem consciência de que mesmo não gostando, precisa aprender a gerir seu negócio & 1 & 1 & Não \\
\hline Tem contador, mantém contato com ele, mas não o vê como parceiro & 1 & 1 & Não \\
\hline
\end{tabular}




\begin{tabular}{|c|c|c|c|}
\hline \multirow[b]{2}{*}{ Nome do nó } & \multicolumn{2}{|c|}{ Codificação Inicial } & \multirow[b]{2}{*}{$\begin{array}{c}\text { Nó } \\
\text { mantido } \\
\text { na } \\
\text { Focada? }\end{array}$} \\
\hline & $\begin{array}{l}\text { Quant. } \\
\text { Fontes }\end{array}$ & $\begin{array}{c}\text { Quant. } \\
\text { Referências }\end{array}$ & \\
\hline Tem contadora para a PF, mas não para a PJ & 1 & 1 & "Não \\
\hline Tem empresário que acha que a função do contador é apenas calcular tributos & 1 & 1 & Não \\
\hline $\begin{array}{l}\text { Tem o mesmo contador desde a abertura de sua segunda empresa, quando empreendeu } \\
\text { por vontade própria }\end{array}$ & 1 & 1 & Não \\
\hline Tem uma ideia de rentabilidade na cabeça, mas não colocou na ponta do lápis & 1 & 1 & Não \\
\hline Tempo de maturação do negócio que ainda está em fase primária & 1 & 1 & Não \\
\hline Tempo para ajuste jurídico e contábil para o negócio se readequar & 1 & 1 & Não \\
\hline Tentar conduzir o empresário para a melhor solução possível & 1 & 1 & Não \\
\hline $\begin{array}{l}\text { Ter empresa aberta com alternativa à CLT era uma exigência no mercado onde atuava, } \\
\text { arquitetura }\end{array}$ & 1 & 1 & Não \\
\hline Ter jogo de cintura para interceder nos conflitos entre egos das sócias & 1 & 1 & Não \\
\hline Ter um negócio é diferente de ser empreendedor & 1 & 1 & Não \\
\hline $\begin{array}{l}\text { Terceirização da contabilidade como alternativa de redução de custos e desinchaço da } \\
\text { empresa }\end{array}$ & 1 & 1 & Não \\
\hline Termos contábeis simples são bem entendidos pelos empresários & 1 & 1 & Não \\
\hline Teve contador desde o início do negócio, momento em que não pagava os impostos & 1 & 1 & Não \\
\hline Tinha contador, mas não recebiam orientações dele & 1 & 1 & Não \\
\hline $\begin{array}{l}\text { Tinha plano de negócios, empresa começou a funcionar, mas sem formalização, não } \\
\text { procurou contador }\end{array}$ & 1 & 1 & Não \\
\hline Tipos de PE atendidas & 1 & 1 & Não \\
\hline Trabalho que o escritório tem com uma ME & 1 & 2 & Não \\
\hline $\begin{array}{l}\text { Trabalho que uma empresa dá para o escritório é medido por quantidade de horas de } \\
\text { funcionário e número de lançamentos }\end{array}$ & 1 & 1 & Não \\
\hline Trabalho técnico $\mathrm{X}$ avaliações & 1 & 1 & Não \\
\hline $\begin{array}{l}\text { Tradução da linguagem normativa, seca e dura, para uma linguagem flexível, mais } \\
\text { solta, mas relaxada }\end{array}$ & 1 & 1 & Não \\
\hline Transformação em função das IFRS talvez ocorra na próxima geração & 1 & 1 & Não \\
\hline Treinar funcionário para o concorrente & 1 & 1 & Não \\
\hline Treinar gradativamente o cliente para apreciar informações contábeis & 1 & 1 & Não \\
\hline $\begin{array}{l}\text { Tributação deveria ser gradual à medida que a empresa fosse amadurecendo, se } \\
\text { consolidando }\end{array}$ & 1 & 1 & Não \\
\hline $\begin{array}{l}\text { Tripla jornada, empresária e família atrapalhando o planejamento e o tempo para o } \\
\text { negócio }\end{array}$ & 1 & 1 & Não \\
\hline Tudo faz ficar complicado & 1 & 1 & Não \\
\hline Universidade pode ajudar o empresário que aprende pela dor & 1 & 1 & Não \\
\hline $\begin{array}{l}\text { Universidade precisa formar contadores preocupados em se adequarem às diferenças da } \\
\text { PE }\end{array}$ & 1 & 1 & Não \\
\hline Usa cartão pessoal para compras do negócio. Reservou um cartão para isso & 1 & 1 & Não \\
\hline Uso de índices para dosar carga de informação & 1 & 1 & Não \\
\hline Uso de vídeo em curso como recurso para incentivar questionamentos & 1 & 1 & Não \\
\hline Uso do critério fiscal, simples nacional, para definição do porte de seus clientes & 1 & 1 & Não \\
\hline Vai demorar, mas é inevitável a mudança na relação contador e PAPNs & 1 & 1 & Não \\
\hline Vaidades individuais das parceiras: sócias & 1 & 1 & Não \\
\hline Valor a ser cobrado pela consultoria & 1 & 2 & Não \\
\hline Valor da consultoria proporcional ao tamanho da empresa atendida & 1 & 1 & Não \\
\hline Vê cursos do SEBRAE como importantes na sua tentativa de reerguer a empresa & 1 & 1 & Não \\
\hline Venda da carteira de clientes aos funcionários no futuro com renda mensal & 1 & 1 & Não \\
\hline Vendas dependentes do clima demandam cautela & 1 & 1 & Não \\
\hline
\end{tabular}




\begin{tabular}{|c|c|c|c|}
\hline \multirow[b]{2}{*}{ Nome do nó } & \multicolumn{2}{|c|}{ Codificação Inicial } & \multirow[b]{2}{*}{$\begin{array}{c}\text { Nó } \\
\text { mantido } \\
\text { na } \\
\text { Focada? }\end{array}$} \\
\hline & $\begin{array}{l}\text { Quant. } \\
\text { Fontes }\end{array}$ & $\begin{array}{c}\text { Quant. } \\
\text { Referências }\end{array}$ & \\
\hline Vergonha do cliente em perguntar o significado dos termos & 1 & 1 & Não \\
\hline Vida empresarial misturada com vida pessoal & 1 & 1 & Não \\
\hline Visão de contador fardo é ruim para ambos lados & 1 & 1 & Não \\
\hline Visitas comerciais por parte do contador & 1 & 1 & Não \\
\hline Viu na internet que MEI não precisaria de contador, confirmou com amigos & 1 & 1 & Não \\
\hline Vivemos um período de transformação na contabilidade. $\mathrm{O}$ ajuste levará um tempo & 1 & 1 & Não \\
\hline Viveu uma fase de bastante trabalho até o nascimento de seu filho & 1 & 1 & Não \\
\hline
\end{tabular}

